Prepared in cooperation with the California State Water Resources Control Board A product of the California Groundwater Ambient Monitoring and Assessment (GAMA) Program

\title{
Status and Understanding of Groundwater Quality in the South Coast Range-Coastal Study Unit, 2008: California GAMA Priority Basin Project
}

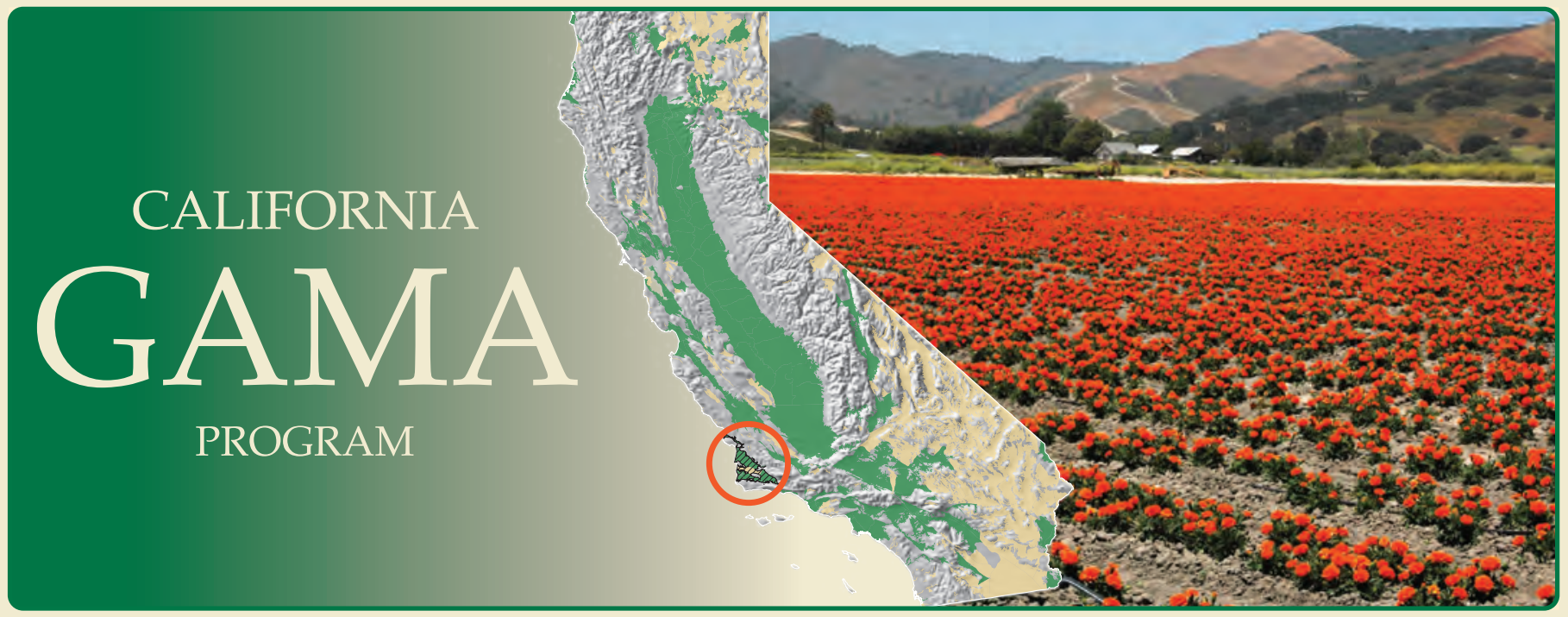

Scientific Investigations Report 2013-5053 
Front Cover Map: Groundwater basins categorized by sampling priority. Location of groundwater basin boundaries from California Department of Water Resources (CDWR, 2003).

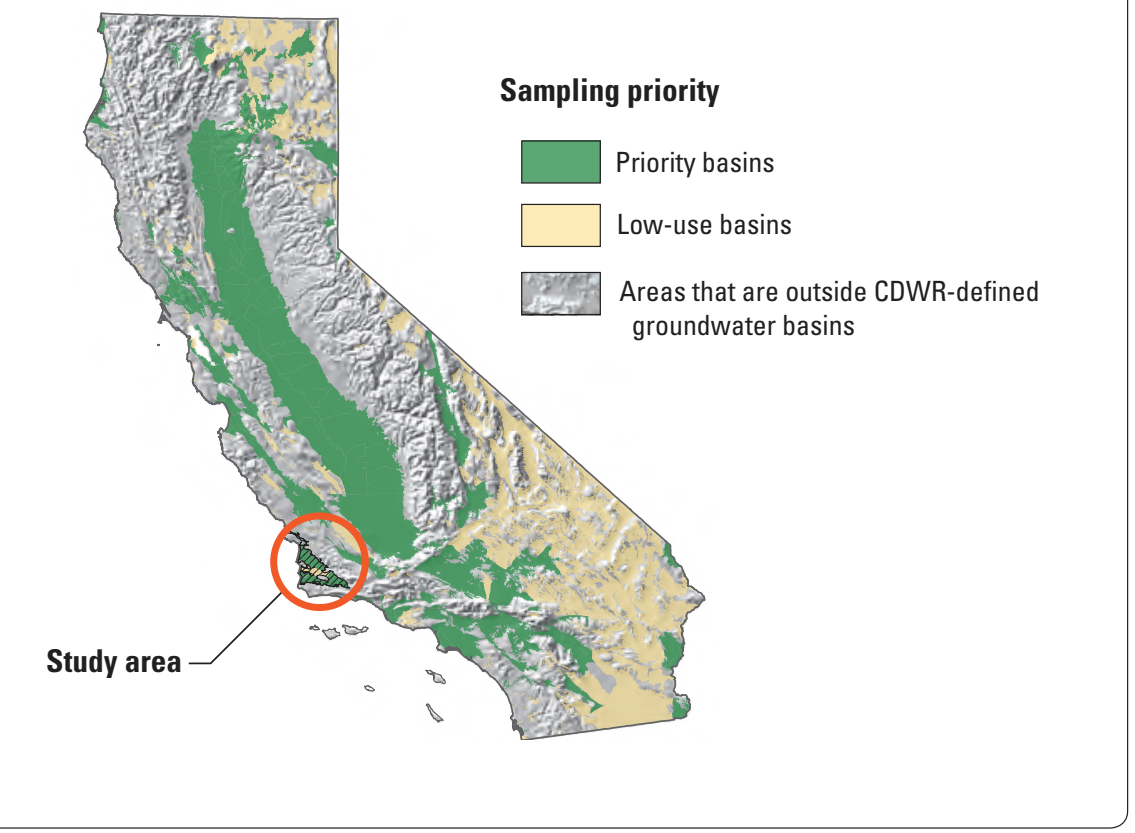

\section{Cover photographs:}

Front cover: Marigold farm near Lompoc, California. (Photograph taken by Cathy Munday, U.S. Geological Survey.)

Back cover: Irrigation well, Lompoc, California. (Photograph taken by Dara Goldrath, U.S. Geological Survey.) 


\section{Status and Understanding of Groundwater Quality in the South Coast Range-Coastal Study Unit, 2008: California GAMA Priority Basin Project}

By Carmen A. Burton, Michael T. Land, and Kenneth Belitz

A product of the California Groundwater Ambient Monitoring and Assessment (GAMA) Program

Prepared in cooperation with the California State Water Resources Control Board

Scientific Investigations Report 2013-5053 


\title{
U.S. Department of the Interior SALLY JEWELL, Secretary
}

\section{U.S. Geological Survey Suzette M. Kimball, Acting Director}

\author{
U.S. Geological Survey, Reston, Virginia: 2013
}

For more information on the USGS - the Federal source for science about the Earth, its natural and living resources, natural hazards, and the environment, visit http://www.usgs.gov or call 1-888-ASK-USGS.

For an overview of USGS information products, including maps, imagery, and publications, visit http://www.usgs.gov/pubprod

To order this and other USGS information products, visit http://store.usgs.gov

Any use of trade, firm, or product names is for descriptive purposes only and does not imply endorsement by the U.S. Government.

Although this information product, for the most part, is in the public domain, it also may contain copyrighted materials as noted in the text. Permission to reproduce copyrighted items must be secured from the copyright owner.

Suggested citation:

Burton, C.A., Land, M.T., and Belitz, Kenneth, 2013, Status and understanding of groundwater quality in the South Coast Range-Coastal study unit, 2008 - California GAMA Priority Basin Project: U.S. Geological Survey Scientific Investigations Report 2013-5053, 86 p. 


\section{Contents}

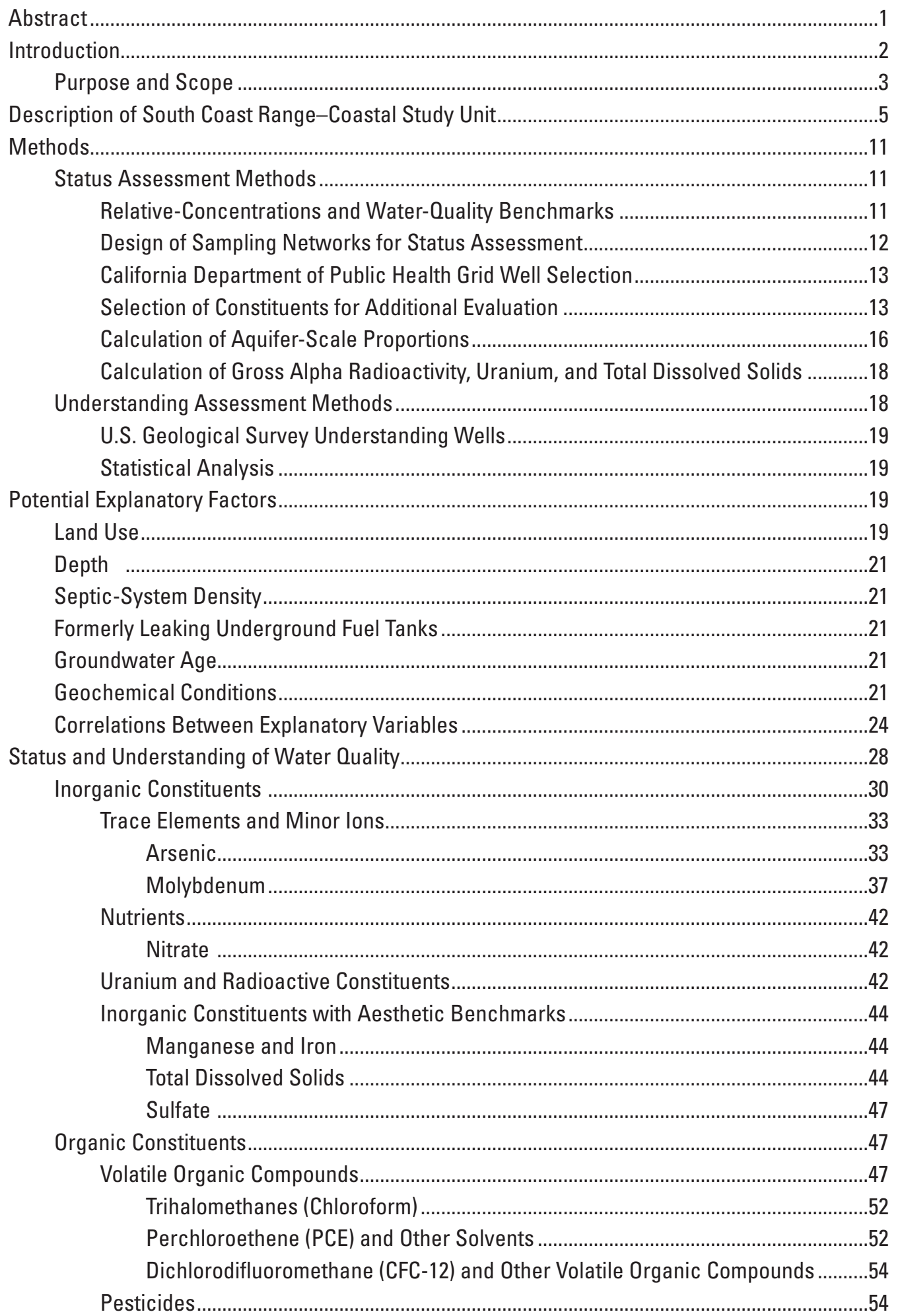




\section{Contents-Continued}

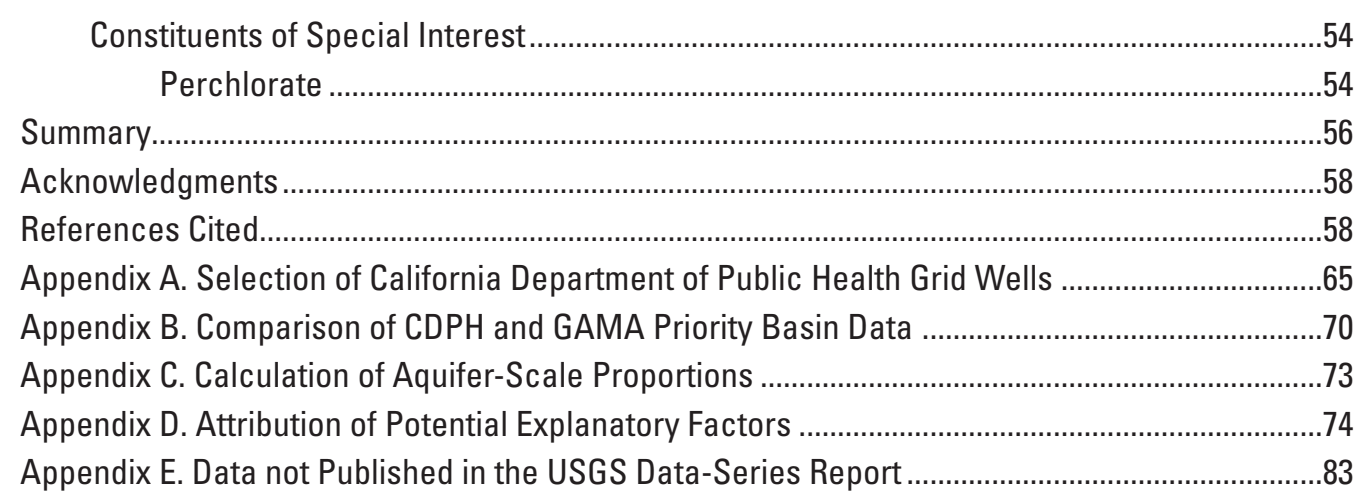

\section{Figures}

1. Map showing location of the South Coast Range-Coastal study unit and California hydrogeologic provinces (modified from Belitz and others, 2003), California GAMA Priority Basin Project...

2. Map showing study areas, groundwater basins, and geographic features of the South Coast Range-Coastal study unit, California GAMA Priority Basin Project.

3. Map showing land use in the South Coast Range-Coastal study unit, California GAMA Priority Basin Project.

4. Map showing geology and study areas in the South Coast Range-Coastal study unit, California GAMA Priority Basin Project.

5. Map showing grid cells, USGS-grid and USGS-understanding wells sampled during May-December 2008, CDPH-grid wells sampled for inorganic constituents, and generalized groundwater flow for the South Coast Range-Coastal study unit, California GAMA Priority Basin Project.

6. Ternary diagram with proportions of natural, agricultural, and urban land use for wells and the study unit and study areas, South Coast Range-Coastal study unit, California GAMA Priority Basin Project.

7. Graphs showing construction characteristics for USGS- and CDPH-grid wells and USGS-understanding wells and grid wells in the Basins and Uplands study areas, South Coast Range-Coastal study unit, California GAMA Priority Basin Project ...........22

8. Graphs showing groundwater age classification in relation to study areas, well depth, and depth to top-of-perforations, South Coast Range-Coastal study unit, California GAMA Priority Basin Project

9. Graph showing relation of groundwater age classification to numbers of wells in each of the three depth categories, South Coast Range-Coastal study unit, California GAMA Priority Basin Project.

10. Maps showing dissolved oxygen concentrations and $\mathrm{pH}$ values for wells in the South Coast Range-Coastal study unit, California GAMA Priority Basin Project. 


\section{Figures-Continued}

11. Graph showing maximum relative-concentration in USGS- and CDPH-grid wells for detected constituents by constituent class, South Coast Range-Coastal

study unit, California GAMA Priority Basin Project. .31

12. Graphs showing relative-concentrations of inorganic constituents having humanhealth-based or SMCL benchmarks and high or moderate maximum relativeconcentrations in USGS- and CDPH-grid wells, South Coast Range-Coastal study unit, California GAMA Priority Basin Project.

13. Maps showing relative-concentrations of arsenic, molybdenum, and nitrate in USGS-grid and CDPH-grid wells and CDPH-other wells in the South Coast Range-Coastal study unit, California GAMA Priority Basin Project.

14. Graphs showing relation of arsenic concentrations to manganese concentrations and groundwater age in the Basins study area and dissolved oxygen concentrations in the Uplands study area, South Coast Range-Coastal study unit, California GAMA Priority Basin Project.

15. Graphs showing relation of molybdenum concentrations to well depth and groundwater age and to arsenic and dissolved oxygen concentrations and $\mathrm{pH}$ in wells with disolved oxygen greater than 0.5 milligram per liter, South Coast Range-Coastal study unit, California GAMA Priority Basin Project.

16. Graph showing relation of nitrate concentrations to dissolved oxygen concentrations, groundwater age, and well perforation intervals in the South Coast Range-Coastal study unit, California GAMA Priority Basin Project.

17. Maps showing relative-concentrations of manganese, iron, total dissolved solids, and sulfate in USGS-grid and CDPH-grid wells, USGS-understanding wells, and CDPH-other wells in the South Coast Range-Coastal study unit, California GAMA Priority Basin Project.

18. Graph showing detection frequencies and maximum relative-concentrations of organic and special-interest constituents detected in USGS-grid wells in the South Coast Range-Coastal study unit, California GAMA Priority Basin Project

19. Graphs showing detection frequencies and relative-concentrations of selected organic and special-interest constituents in USGS-grid wells in the South Coast Range-Coastal study unit, California GAMA Priority Basin Project.

20. Maps showing number of volatile organic compound (VOC) detections, trihalomethane (chloroform) concentrations, perchloroethene concentrations, number of other VOC detections, and number of pesticide detections in USGS-grid and USGS-understanding wells, and CDPH-wells in the South Coast RangeCoastal study unit, California GAMA Priority Basin Project.

21. Graph showing relation of the number of pesticide detections per well with well depth and groundwater age in the South Coast Range-Coastal study unit, California GAMA Priority Basin Project.

22. Map showing perchlorate concentrations in USGS-grid wells, USGSunderstanding wells, and CDPH-wells in the South Coast Range-Coastal study unit, California GAMA Priority Basin Project.

23. Graph showing relation of perchlorate concentrations to dissolved oxygen concentrations in the South Coast Range-Coastal study unit, California GAMA Priority Basin Project. 


\section{Tables}

1. Analytes and wells sampled for each analytical schedule for the South Coast Range-Coastal study unit, California GAMA Priority Basin Project, May-November 2008

2. Inorganic constituents, associated benchmark information, and number of grid wells per constituent, South Coast Range-Coastal study unit, California GAMA Priority Basin Project

3. Comparison of the number of compounds and median method detection levels or laboratory reporting levels by constituent class for data stored in the CDPH database and for data collected by the U.S. Geological Survey in the South Coast Range-Coastal study unit, California GAMA Priority Basin Project, May-November 2008

4. Constituents in CDPH wells with historically high concentrations but not high during the current period (May 20, 2005, to May 19, 2008) in the South Coast Range-Coastal study unit, California GAMA Priority Basin Project

5. Results of nonparametric statistical tests (Kruskal-Wallis or Wilcoxon) for differences in values of potential categorical and continuous explanatory factors and differences in values of potential categorical explanatory factors and selected water-quality constituents for the South Coast Range-Coastal study unit, California GAMA Priority Basin Project.

6. Results of nonparametric (Spearman's method) analysis of correlations between selected potential explanatory factors in grid and understanding wells, South Coast Range-Coastal study unit, California GAMA Priority Basin Project.

7. Number of constituents analyzed and detected in USGS-grid wells, listed by human-health-based or aesthetic benchmarks and constituent class, in the South Coast Range-Coastal study unit, California GAMA Priority Basin Project.

8. Raw detection frequencies and aquifer-scale proportions using spatially weighted and grid-based methods for constituents detected at concentrations greater than water-quality benchmarks during the most recent 3 years of data available (May 20, 2005, to May 19, 2008) from the California Department of Public Health database, or detected at high or moderate relative-concentrations in samples collected from USGS-grid wells, or organic compounds detected at frequencies greater than 10 percent in samples collected from USGS-grid wells, May-November 2008 in the South Coast Range-Coastal study unit, California GAMA Priority Basin Project.

9. Aquifer-scale proportions for constituent classes and constituents of special interest for the South Coast Range-Coastal study unit, California GAMA Priority Basin Project.

10. Results of nonparametric (Spearman's method) correlation analysis between selected inorganic water-quality constituents and potential explanatory factors in the South Coast Range-Coastal study unit, California GAMA Priority Basin Project

11. Results of nonparametric correlation analysis (Spearman's method) between selected organic and special-interest water-quality constituents and potential explanatory factors in the South Coast Range-Coastal study unit, California GAMA Priority Basin Project. 


\section{Conversion Factors, Datums, and Abbreviations and Acronyms}

\section{Conversion Factors}

Inch/Pound to SI

\begin{tabular}{lcl}
\hline \multicolumn{1}{c}{ Multiply } & By & \multicolumn{1}{c}{ To obtain } \\
\hline inch (in.) & Length & \\
inch (in.) & 2.54 & centimeter (cm) \\
foot (ft) & 25.4 & millimeter (mm) \\
mile (mi) & 0.3048 & meter (m) \\
\hline & 1.609 & kilometer $(\mathrm{km})$ \\
\hline square foot $\left(\mathrm{ft}^{2}\right)$ & Area & square meter $\left(\mathrm{m}^{2}\right)$ \\
square mile $\left(\mathrm{mi}^{2}\right)$ & 0.09290 & square kilometer $\left(\mathrm{km}^{2}\right)$ \\
\hline & 2.590 & \\
\hline picocurie per liter $(\mathrm{pCi} / \mathrm{L})$ & Radioactivity & becquerel per liter $(\mathrm{Bq} / \mathrm{L})$ \\
picocurie per liter $(\mathrm{pCi} / \mathrm{L})$ & 0.037 & tritium units $(\mathrm{TU})$ \\
\hline
\end{tabular}

SI to Inch/Pound

\begin{tabular}{lll}
\hline \multicolumn{1}{c}{ Multiply } & By & \multicolumn{1}{c}{ To obtain } \\
\hline centimeter $(\mathrm{cm})$ & Length & \\
millimeter $(\mathrm{mm})$ & 0.3937 & inch (in.) \\
meter $(\mathrm{m})$ & 0.03937 & inch (in.) \\
kilometer $(\mathrm{km})$ & 3.281 & foot (ft) \\
\hline & 0.6214 & mile (mi) \\
\hline square meter $\left(\mathrm{m}^{2}\right)$ & Area & square foot $\left(\mathrm{ft}^{2}\right)$ \\
square kilometer $\left(\mathrm{km}^{2}\right)$ & 10.76 & square mile $\left(\mathrm{mi}^{2}\right)$ \\
\hline
\end{tabular}

Temperature in degrees Celsius $\left({ }^{\circ} \mathrm{C}\right)$ may be converted to degrees Fahrenheit $\left({ }^{\circ} \mathrm{F}\right)$ as follows:

${ }^{\circ} \mathrm{F}=\left(1.8 \times{ }^{\circ} \mathrm{C}\right)+32$

Specific conductance is given in microsiemens per centimeter at 25 degrees Celsius $(\mu \mathrm{S} / \mathrm{cm}$ at $\left.25^{\circ} \mathrm{C}\right)$.

Concentrations of chemical constituents in water are given either in milligrams per liter ( $\mathrm{mg} / \mathrm{L}$ ) or micrograms per liter ( $\mu \mathrm{g} / \mathrm{L})$. One milligram per liter is equivalent to 1 part per million (ppm); 1 microgram per liter is equivalent to 1 part per billion (ppb).

Horizontal coordinate information is referenced to the North American Datum of 1983 (NAD 83). 


\section{Conversion Factors, Datums, and Abbreviations and Acronyms-Continued}

Abbreviations and Acronyms

AB Assembly Bill (through the California State Assembly)

AL-US U.S. Environmental Protection Agency action level

bls below land surface

GAMA Groundwater Ambient Monitoring and Assessment Program

HAL-US U.S. Environmental Protection Agency lifetime health advisory level

HBSL health-based screening level

LRL laboratory reporting level

LUFT leaking underground fuel tank

MCL-CA California Department of Public Health maximum contaminant level

MCL-US U.S. Environmental Protection Agency maximum contaminant level

MDL method detection limit

NL-CA California Department of Public Health notification level

OC quality control

RPD relative percent difference

RSD5-US U.S. Environmental Protection Agency risk-specific dose at a risk factor of $10^{-5}$

SC specific conductance

SCRC South Coast Range-Coastal study unit

SMCL-CA California Department of Public Health secondary maximum contaminant level

SMCL-US U.S. Environmental Protection Agency secondary maximum contaminant level

TEAP terminal electron acceptor process

TT-US U.S. Environmental Protection Agency treatment technique

Organizations

CDPH California Department of Public Health (Department of Health Services prior to July 1, 2007)

CDPR California Department of Pesticide Regulation

CDWR California Department of Water Resources

LLNL Lawrence Livermore National Laboratory

NAWQA National Water-Quality Assessment Program (USGS)

SWRCB State Water Resources Control Board (California)

USEPA U.S. Environmental Protection Agency

USGS U.S. Geological Survey 


\section{Conversion Factors, Datums, and Abbreviations and} Acronyms-Continued

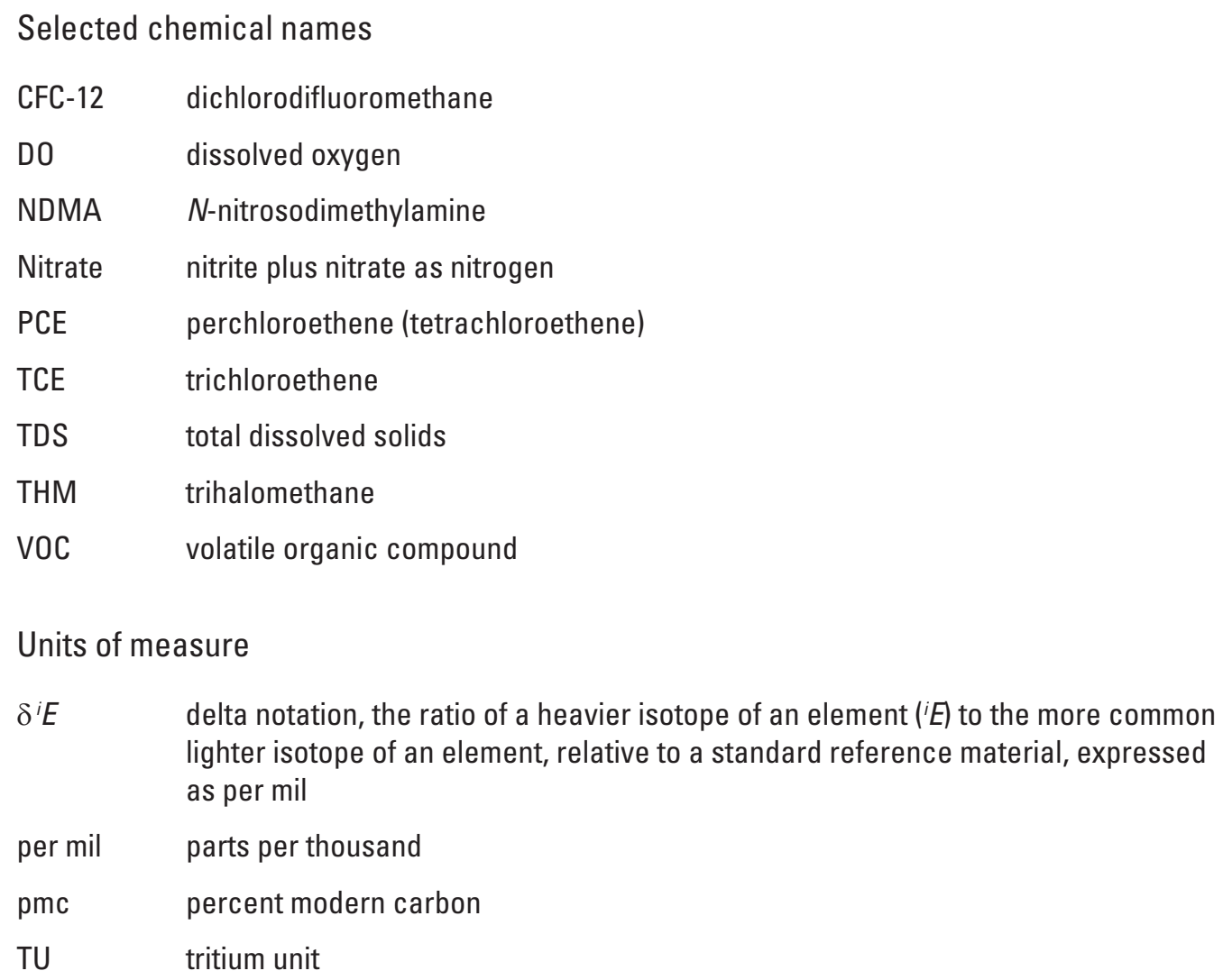

TU tritium unit 
This page intentionally left blank 


\title{
Status and Understanding of Groundwater Quality in the South Coast Range-Coastal Study Unit, 2008: California GAMA Priority Basin Project
}

\author{
By Carmen A. Burton, Michael T. Land, and Kenneth Belitz
}

\section{Abstract}

Groundwater quality in the South Coast Range-Coastal (SCRC) study unit was investigated from May through November 2008 as part of the Priority Basin Project of the Groundwater Ambient Monitoring and Assessment (GAMA) Program. The study unit is located in the Southern Coast Range hydrologic province and includes parts of Santa Barbara and San Luis Obispo Counties. The GAMA Priority Basin Project is conducted by the U.S. Geological Survey (USGS) in collaboration with the California State Water Resources Control Board and the Lawrence Livermore National Laboratory.

The GAMA Priority Basin Project was designed to provide a statistically unbiased, spatially distributed assessment of untreated groundwater quality within the primary aquifer system. The primary aquifer system is defined as that part of the aquifer corresponding to the perforation interval of wells listed in the California Department of Public Health (CDPH) database for the SCRC study unit.

The assessments for the SCRC study unit were based on water-quality and ancillary data collected in 2008 by the USGS from 55 wells on a spatially distributed grid, and water-quality data from the CDPH database. Two types of assessments were made: (1) status, assessment of the current quality of the groundwater resource, and (2) understanding, identification of the natural and human factors affecting groundwater quality. Water-quality and ancillary data were collected from an additional 15 wells for the understanding assessment. The assessments characterize untreated groundwater quality, not the quality of treated drinking water delivered to consumers by water purveyors.

The first component of this study, the status assessment of groundwater quality, used data from samples analyzed for anthropogenic constituents such as volatile organic compounds (VOCs) and pesticides, as well as naturally occurring inorganic constituents such as major ions and trace elements. Although the status assessment applies to untreated groundwater, Federal and California regulatory and nonregulatory water-quality benchmarks that apply to drinking water are used to provide context for the results. Relativeconcentrations (sample concentration divided by benchmark concentration) were used for evaluating groundwater. A relative-concentration greater than $(>) 1.0$ indicates a concentration greater than the benchmark and is classified as high. Inorganic constituents are classified as moderate if relative-concentrations are $>0.5$ and less than or equal to $(\leq)$ 1.0 , or low if relative-concentrations are $\leq 0.5$. For organic constituents, the boundary between moderate and low relativeconcentrations was set at 0.1 .

Aquifer-scale proportion was used in the status assessment as the primary metric for evaluating regional-scale groundwater quality. High aquifer-scale proportion is defined as the areal percentage of the primary aquifer system with a high relative-concentration for a particular constituent or class of constituents. Moderate and low aquifer-scale proportions were defined as the areal percentage of the primary aquifer system with moderate and low relative-concentrations, respectively. Two statistical approaches_-grid-based and spatially weighted-were used to evaluate aquifer-scale proportions for individual constituents and classes of constituents. Grid-based and spatially weighted estimates were comparable for the study (within 90 percent confidence intervals).

For inorganic constituents with human-health benchmarks, relative-concentrations were high for at least one constituent for 33 percent of the primary aquifer system in the SCRC study unit. Arsenic, molybdenum, and nitrate were the primary inorganic constituents with human-health benchmarks that were detected at high relative-concentrations. Inorganic constituents with aesthetic benchmarks, referred to as secondary maximum contaminant levels (SMCLs), had high relative-concentrations for 35 percent of the primary aquifer system. Iron, manganese, total dissolved solids (TDS), and sulfate were the inorganic constituents with SMCLs detected at high relative-concentrations. 
In contrast to inorganic constituents, organic constituents with human-health benchmarks were not detected at high relative-concentrations in the primary aquifer system in the SCRC study unit. Of the 205 organic constituents analyzed, 21 were detected-13 with humanhealth benchmarks. Perchloroethene (PCE) was the only VOC detected at moderate relative-concentrations. PCE, dichlorodifluoromethane (CFC-12), and chloroform were detected in more than 10 percent of the primary aquifer system. Of the two special-interest constituents, one was detected; perchlorate, which has a human-health benchmark, was detected at moderate relative-concentrations in 29 percent of the primary aquifer system and had a detection frequency of 60 percent in the SCRC study unit.

The second component of this study, the understanding assessment, identified the natural and human factors that may have affected groundwater quality in the SCRC study unit by evaluating statistical correlations between waterquality constituents and potential explanatory factors. The potential explanatory factors evaluated were land use, septic tank density, well depth and depth to top-ofperforations, groundwater age, density and distance to the nearest formerly leaking underground fuel tank (LUFT), $\mathrm{pH}$, and dissolved oxygen (DO) concentration. Results of the statistical evaluations were used to explain the occurrence and distribution of constituents in the study unit.

DO was the primary explanatory factor influencing the concentrations of many inorganic constituents. Arsenic, iron, and manganese concentrations increased as DO concentrations decreased, consistent with patterns expected as a result of reductive dissolution of iron and (or) manganese oxides in aquifer sediments. Molybdenum concentrations increased in anoxic conditions and in oxic conditions with high $\mathrm{pH}$, reflecting two mechanisms for the mobilization of molybdenum - reductive dissolution and $\mathrm{pH}$-dependent desorption under oxic conditions from aquifer sediments. Nitrate concentrations decreased as DO concentrations decreased which would be consistent with degradation of nitrate under anoxic conditions (denitrification). It also is possible that nitrate concentrations decreased in relation to increasing depth and groundwater age and not as a result of denitrification.

Groundwater age was another explanatory factor frequently correlated to several inorganic constituents. Iron and manganese concentrations were higher in pre-modern (water recharged before 1952) or mixed-age groundwater. This correlation is one indication that iron and manganese are from natural sources. Nitrate, TDS, and sulfate concentrations were higher in modern groundwater (water recharged since 1952) and may indicate that human activities increase concentrations of nitrate, TDS, and sulfate.

Land use was a third explanatory factor frequently correlated with inorganic constituents. Nitrate, TDS, and sulfate concentrations were higher in agricultural land-use areas than in natural land-use areas, indicating that increased concentrations may be a result of agricultural practices.
Organic constituents usually were detected at low relative-concentrations; therefore, statistical analyses of relations to explanatory factors usually were done for classes of constituents (for example, pesticides or solvents) as well as for selected constituents. The number of VOCs detected in a well was not correlated to any of the explanatory factors evaluated. The number of pesticide and solvent detections and PCE and CFC-12 concentrations were higher in modern groundwater than in pre-modern groundwater. PCE and CFC12 also were positively correlated to the density of LUFTs. PCE was negatively correlated to natural land use. Chloroform concentrations were positively correlated to the density of septic systems.

Perchlorate concentrations were greater in agricultural areas than in urban or natural areas. Correlation of perchlorate with DO may indicate that perchlorate biodegradation under anoxic conditions may occur. Anthropogenic sources have contributed perchlorate to groundwater in the SCRC study unit, although low levels of perchlorate may occur naturally.

\section{Introduction}

Groundwater composes nearly half of the water used for public supply in California (Hutson and others, 2004). To assess the quality of ambient groundwater in aquifers used for drinking-water supply and to establish a baseline groundwater-quality monitoring program, the California State Water Resources Control Board (SWRCB), in collaboration with the U.S. Geological Survey (USGS) and Lawrence Livermore National Laboratory (LLNL), implemented the Groundwater Ambient Monitoring and Assessment (GAMA) Program (California State Water Resources Control Board, 2011, website at http://www.waterboards.ca.gov/water issues/ programs/gama). The statewide GAMA Program currently consists of four projects: (1) the GAMA Priority Basin Project, conducted by the USGS; (2) the GAMA Domestic Well Project, conducted by the SWRCB; (3) the GAMA Special Studies, conducted by LLNL; and (4) GeoTracker GAMA, conducted by the SWRCB. On a statewide basis, the GAMA Priority Basin Project primarily focused on the deep portion of the groundwater resource (primary aquifer system), and the SWRCB Domestic Well Project generally focused on the shallow aquifer systems. The primary aquifer system may be at less risk of contamination than the shallow wells, such as private domestic or environmental monitoring wells, that are closer to surficial sources of contaminants. As a result, concentrations of contaminants, such as volatile organic compounds (VOCs) and nitrate, in wells screened in the deeper primary aquifer system may be lower than concentrations of contaminants in shallow wells (Kulongoski and others, 2010; Landon and others, 2010; Burton and others, 2012). 
The SWRCB initiated the GAMA Program in 2000 in response to Legislative mandates (State of California, 1999, 2001a; Supplemental Report of the 1999 Budget Act 1999-00 Fiscal Year). The GAMA Priority Basin Project was initiated in response to the Groundwater Quality Monitoring Act of 2001 (State of California, 2001b, Sections 10780-10782.3 of the California Water Code, Assembly Bill 599) to assess and monitor the quality of groundwater in California. The GAMA Priority Basin Project is a comprehensive assessment of statewide groundwater quality designed to improve the understanding of and to identify risks to groundwater resources and to increase the availability of information about groundwater quality to the public. For the GAMA Priority Basin Project, the USGS, in collaboration with the SWRCB, developed a monitoring plan to assess groundwater basins through direct and other statistically reliable sampling approaches (Belitz and others, 2003; California State Water Resources Control Board, 2003). Additional partners in the GAMA Priority Basin Project include the California Department of Public Health (CDPH), the California Department of Pesticide Regulation (CDPR), the California Department of Water Resources (CDWR), and local water agencies and well owners (Kulongoski and Belitz, 2004).

The range of hydrologic, geologic, and climatic conditions in California should be considered in an assessment of groundwater quality. Belitz and others (2003) partitioned the State into 10 hydrogeologic provinces, each with distinctive hydrologic, geologic, and climatic characteristics (fig. 1). These hydrogeologic provinces include groundwater basins and subbasins designated by the CDWR (California Department of Water Resources, 2003). Groundwater basins generally consist of relatively permeable, unconsolidated deposits of alluvial or volcanic origin (California Department of Water Resources, 2003). Eighty percent of California's approximately 16,000 drinkingwater wells listed in the statewide database maintained by the $\mathrm{CDPH}$ (hereinafter referred to as CDPH wells) are located in designated groundwater basins within these hydrologic provinces. Groundwater basins and subbasins were prioritized for sampling on the basis of the number of CDPH wells in the basin or subbasin, with secondary consideration given to municipal groundwater use, agricultural pumping, the number of historical leaking underground fuel tanks, and registered pesticide applications (Belitz and others, 2003). Of the 472 basins and subbasins designated by the CDWR, 116 priority basins, as well as additional areas outside defined groundwater basins, were grouped into 35 study units, which include approximately 95 percent of CDPH wells in California. The South Coast Range-Coastal study unit (hereinafter referred to as the SCRC study unit) is located along the California coast in the southwestern part of the Southern Coast Ranges hydrogeologic province (fig. 1).

\section{Purpose and Scope}

This report is one of a series of GAMA Priority Basin Project assessment reports presenting the status and understanding of current water-quality conditions in GAMA Priority Basin Project study units. The purposes of this report are to provide (1) a study unit description: description of the hydrogeologic setting of the SCRC study unit, (2) a status assessment: assessment of the status of the current quality of groundwater in the primary aquifer system in the SCRC study unit, and (3) an understanding assessment: identification of natural and human factors affecting groundwater quality and the relations between water quality and selected explanatory factors.

This report describes methods used to design the sampling network, identify CDPH data for use in the status assessment, estimate aquifer-scale proportions of relative-concentrations, analyze ancillary datasets, classify groundwater age, and assess the status and understanding of groundwater quality by statistical and graphical approaches. Water-quality data for samples collected by the USGS for the GAMA Program in the SCRC study unit and details of sample collection, analysis, and quality-assurance procedures are reported by Mathany and others (2010).

The status assessment includes analyses of water-quality data for 55 wells selected for sampling by the USGS within spatially distributed grid cells across the SCRC study unit (hereinafter referred to as USGS-grid wells). Samples were collected for analysis of anthropogenic constituents, such as volatile organic compounds (VOCs) and pesticides, and naturally occurring inorganic constituents, such as major ions and trace elements. Water-quality data from the CDPH database were used to supplement data collected by the USGS for the GAMA Priority Basin Project. The resulting set of water-quality data from USGS-grid wells and selected CDPH wells was considered to be representative of the primary aquifer system in the SCRC study unit; the primary aquifer system is defined by the depth intervals of the wells listed in the CDPH database for the SCRC study unit. GAMA status assessments were designed to provide a statistically robust characterization of groundwater quality in the primary aquifer system at the basin-scale (Belitz and others, 2003), which allows for comparisons between basins and allows results to be synthesized regionally and statewide.

The understanding assessment uses data from the 55 USGS-grid wells and selected CDPH wells plus an additional 15 wells sampled by the USGS (hereinafter referred to as USGS-understanding wells) to identify the natural and human factors affecting groundwater quality and to help explain the relations between water quality and selected potential explanatory factors. Potential explanatory factors examined included land use, well depth and depth to top-ofperforations, distance to formerly leaking underground fuel tanks (LUFTs), septic tank density, groundwater age, and geochemical conditions. 


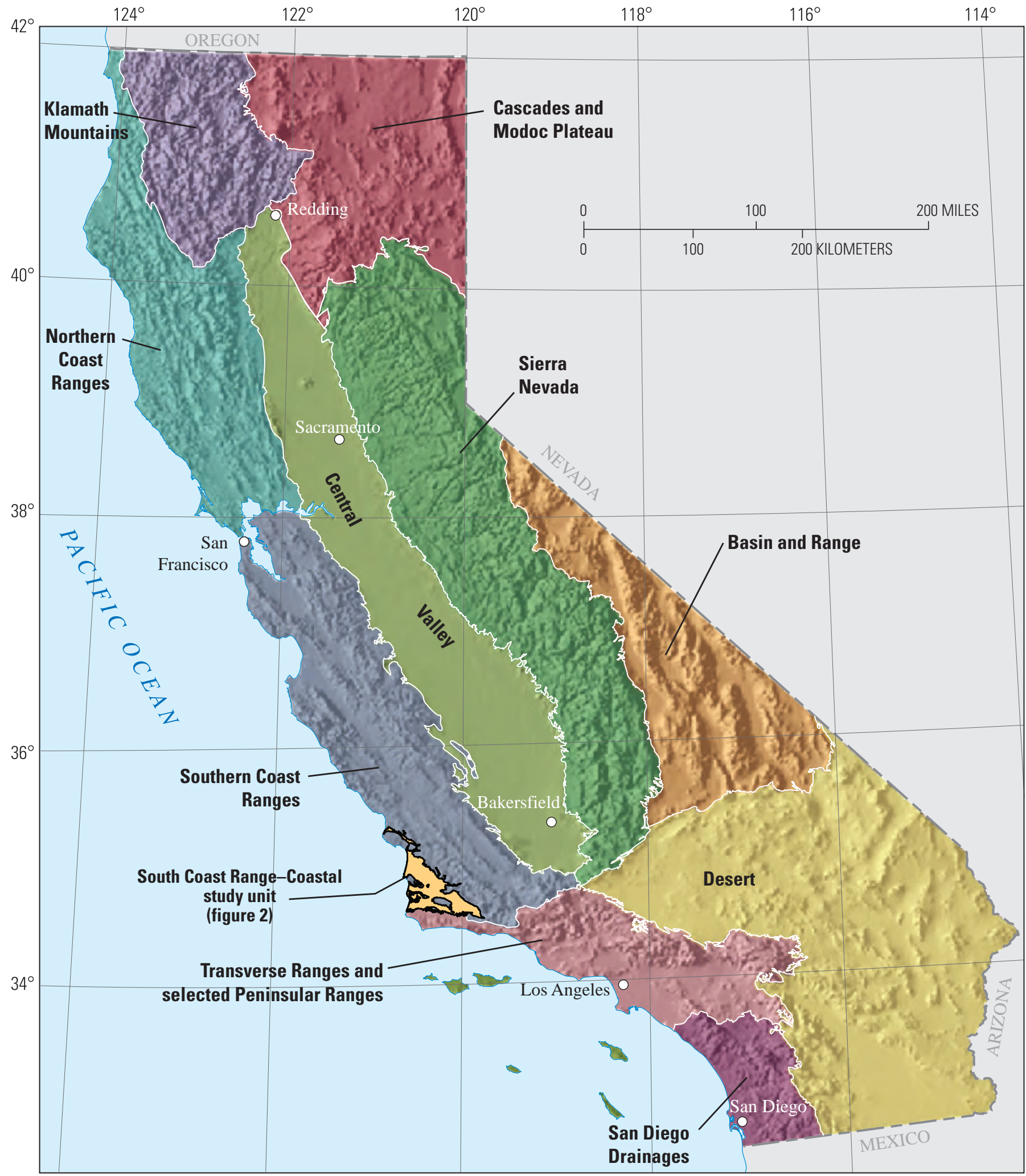

Shaded relief derived from U.S. Geological Survey

Provinces from Belitz and others, 2003 National Elevation Dataset, 2006,

Albers Equal Area Conic Projection

Figure 1. Location of the South Coast Range-Coastal study unit and California hydrogeologic provinces (modified from Belitz and others, 2003), California GAMA Priority Basin Project. 
To provide context, the water-quality data discussed in this report were compared to California and Federal regulatory and non-regulatory benchmarks for treated drinking water. The assessments in this report are intended to characterize the quality of untreated groundwater resources in the primary aquifer system within the study unit, not the treated drinking water delivered to consumers by water purveyors. This study does not attempt to evaluate the quality of water delivered to consumers; after withdrawal from the ground, water typically is treated, disinfected, and (or) blended with other waters to maintain acceptable water quality. Regulatory benchmarks apply to treated water that is delivered to the consumer, not to untreated groundwater.

\section{Description of South Coast Range- Coastal Study Unit}

The SCRC study unit covers approximately 766 square miles $\left(\mathrm{mi}^{2}\right)\left(1,980\right.$ square kilometers [ $\left.\left.\mathrm{km}^{2}\right]\right)$ in Santa Barbara and San Luis Obispo Counties, California, and lies in the southwestern part of the Southern Coast Ranges hydrogeologic province (fig. 1) (Belitz and others, 2003). The SCRC study unit includes five groundwater basins (Los Osos Valley, San Luis Obispo Valley, Santa Maria River Valley, San Antonio Creek Valley, and Santa Ynez River Valley [California Department of Water Resources, 2003]), as well as upland areas that consist of Plio-Pleistocene non-marine and Pliocene marine sediments that are adjacent to the groundwater basins (fig. 2). The SCRC is bordered on the north by the Santa Lucia and San Luis Ranges, on the east by the San Rafael Mountains, on the south by the Santa Ynez Mountains, and on the west by the Pacific Ocean. Altitudes in the SCRC range from sea level, where the study unit boundary touches the Pacific Ocean, to about 6,500 feet (ft) ( $1,980 \mathrm{~m})$ above sea level in the San Rafael Mountains. The major surface-drainage features of the SCRC study unit are the Santa Maria River, Santa Ynez River, San Antonio Creek, and their tributaries, all of which terminate in the Pacific Ocean (fig. 2). The SCRC study unit is divided into two study areas - the Basins and Uplands study areas.

The climate in the SCRC study unit is influenced in large part by the Pacific Ocean as well as by the topography of the surrounding areas. Areas located along the coastal lowlands and (or) valleys near the Pacific Ocean have a coastal climate characterized by warm, dry summers and cool, wet winters. Coastal fog is common throughout the year (Bright and others, 1992). Areas in the SCRC located farther from the Pacific Ocean, on the slopes of the coastal valleys or within the upland areas, have a Mediterranean climate with hot, dry summers and cool, wet winters (Hamlin, 1985). Practically all precipitation in the SCRC occurs from October through
April, with average annual precipitation ranging from about 13 inches (in.) (33 centimeters [cm]) along the coastal lowlands in the Santa Maria River Valley groundwater basin, to more than 20 in. $(51 \mathrm{~cm})$ in the uplands of the San Luis Obispo Valley groundwater basin (California Department of Water Resources, 2004b, c).

Land use in the SCRC study unit primarily is natural. Land use is approximately 61 percent natural, 29 percent agricultural, and 10 percent urban, based on the classification of USGS National Land Cover Data (Nakagaki and others, 2007; fig. 3). The natural land use mostly consists of grasslands, shrubs, and sand. Agricultural land use consists of row crops (such as vegetables and flowers), pasture and hay, and vineyards. The largest urban areas in the SCRC study unit are the cities of Santa Maria, San Luis Obispo, Lompoc, and Arroyo Grande.

The SCRC study unit was separated into the two study areas (Basins and Uplands) by the non-marine and marine geologic formations in the five groundwater basins. The Basins study area is defined by the presence of the Quaternary alluvium and Quaternary sand formations in the Los Osos Valley, Santa Maria River Valley, San Antonio Creek Valley, and Santa Ynez River Valley groundwater basins (California Department of Water Resources, 2004a, c, d, e) (fig. 4). The Uplands study area is delineated largely by the location of the terrace formations of Plio-Pleistocene non-marine and Pliocene marine sediment in the San Luis Obispo, Santa Maria River Valley, San Antonio Creek Valley, and Santa Ynez River Valley groundwater basins (California Department of Water Resources, 2004b, c, d, e) and areas adjacent to the basins (fig. 4).

The Quaternary alluvium and sand formations that were used to delineate the Basins study area are the alluvial deposits located along river channels of Holocene age, the unnamed dune sand formations of Holocene and Pleistocene age, and some terrace deposits of Pleistocene age (Upson and Thomasson, 1951; Bright and others, 1992, 1997; California Department of Water Resources, 2002; California Department of Water Resources, 2004a, b, c, d, e). The alluvium of Holocene age consists of unconsolidated gravel, clay, silt, and sand of fluvial origin (California Department of Water Resources, 2004a, b, c, d, e). Dune sand formations of Pleistocene age occur in the Los Osos Valley and San Antonio Creek Valley groundwater basins, and dune sand of Holocene and Pleistocene age are present in the Santa Maria River Valley groundwater basin (California Department of Water Resources, 2004a, c, d). Terrace deposits of the Orcutt Formation are present in the lower Santa Ynez River Valley. The Paso Robles Formation and the Careaga Sand, which outcrop in the Uplands study area, underlie much of the alluvium and sand dunes in the Basins study area (Wilson, 1959; Yates and Wiese, 1988; California Department of Water Resources, 2004a, b, c, d, e). 


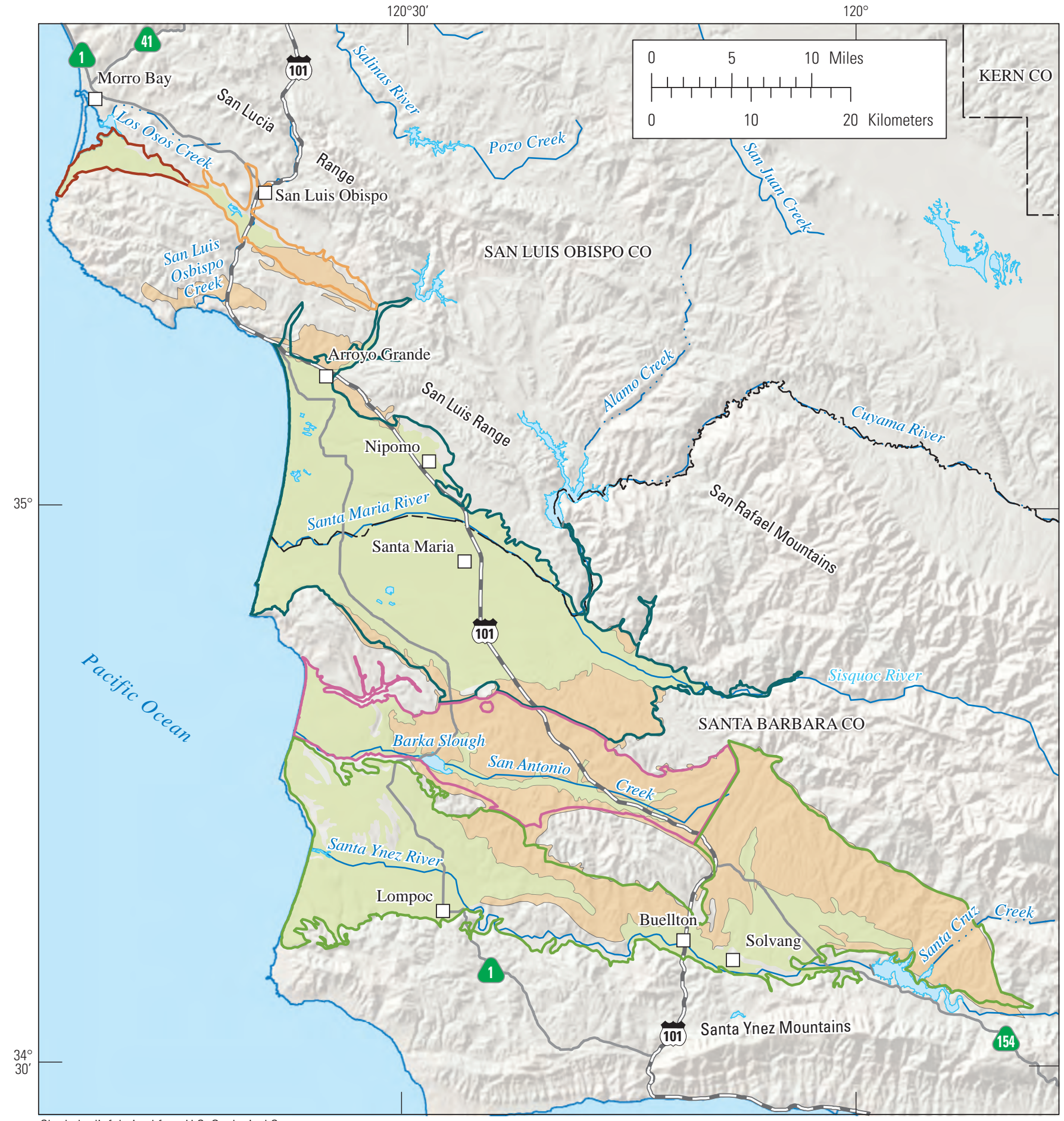

Shaded relief derived from U.S. Geological Survey National Elevation Dataset, 2006,

Albers Equal Area Conic Projection

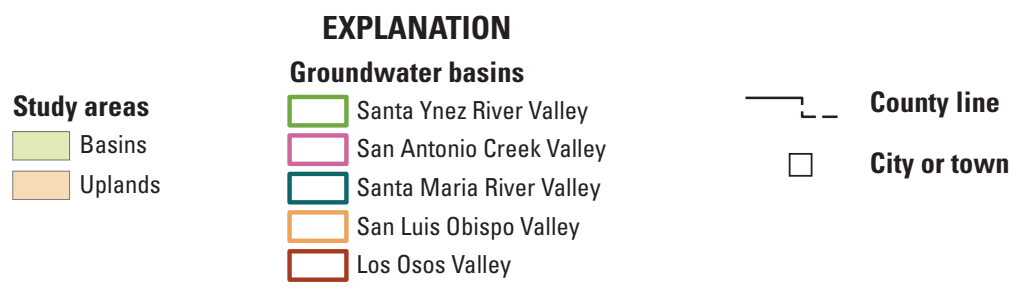

Figure 2. Study areas, groundwater basins, and geographic features of the South Coast Range-Coastal study unit, California GAMA Priority Basin Project. 


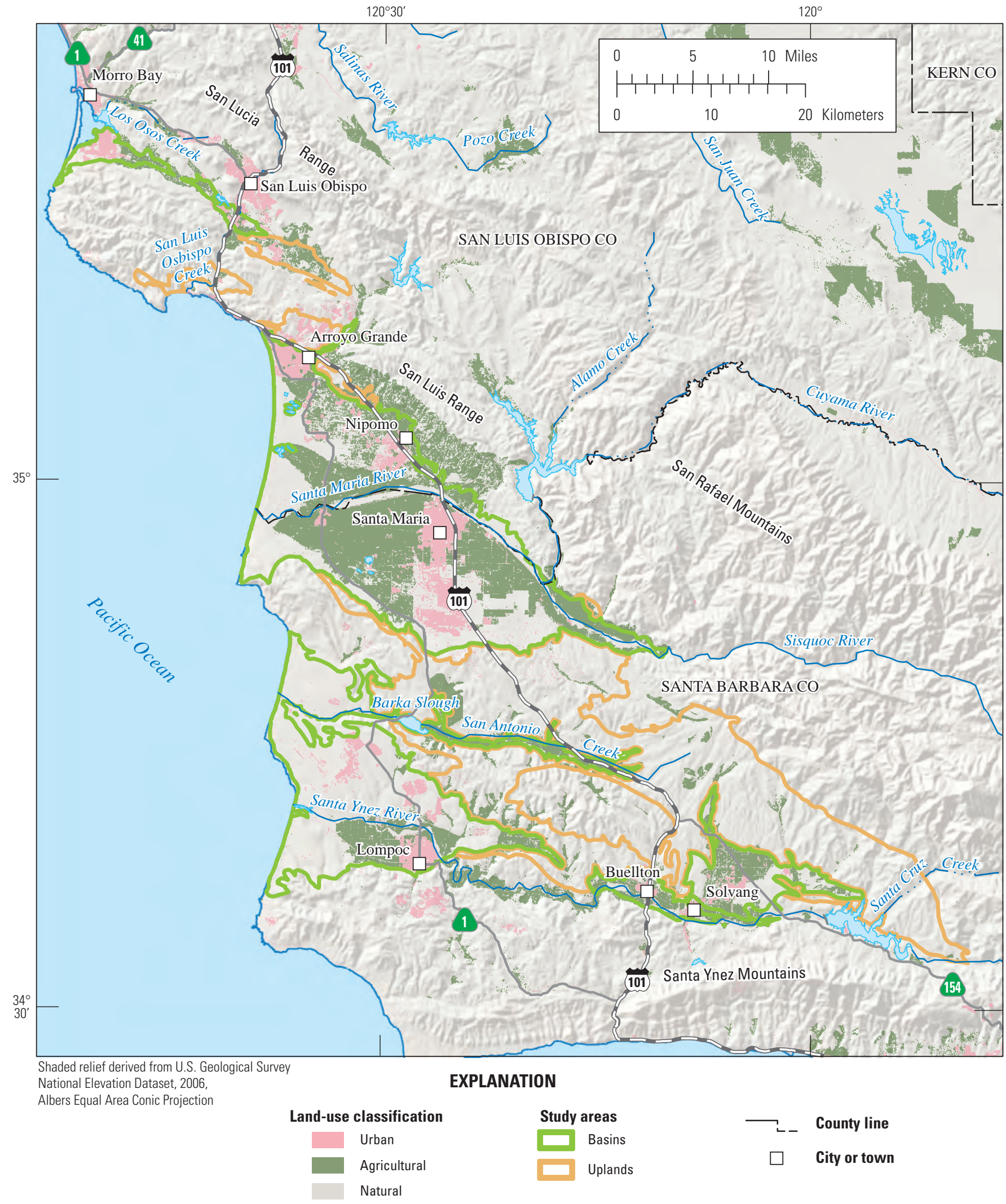

Figure 3. Land use in the South Coast Range-Coastal study unit, California GAMA Priority Basin Project. 


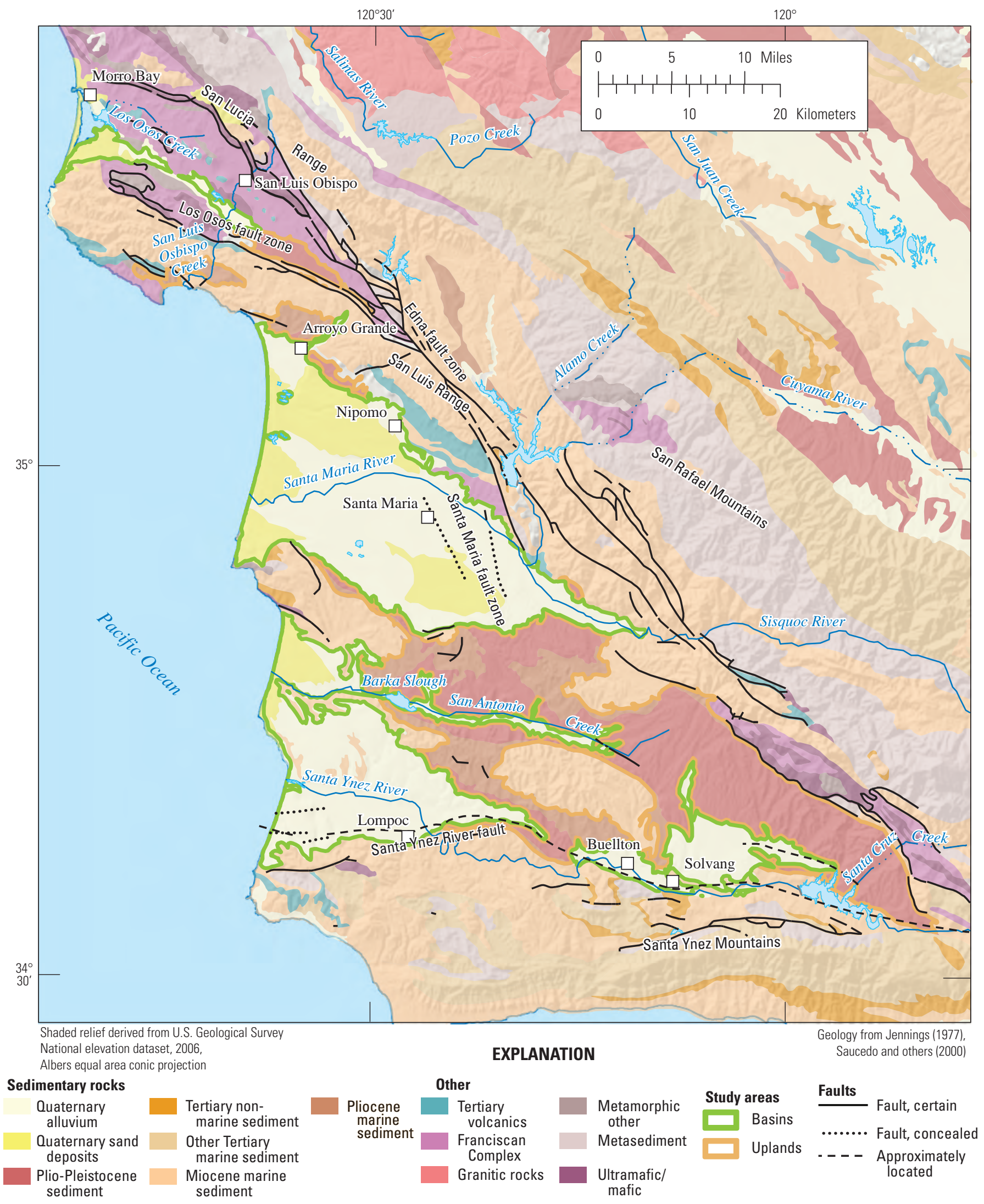

Figure 4. Geology and study areas in the South Coast Range-Coastal study unit, California GAMA Priority Basin Project. 
The geologic formations that were used to delineate the Uplands study area are the non-marine sediments of PlioPleistocene age and marine sediments of Pliocene age. These formations include the alluvial terrace deposits (including the Orcutt Formation), the Paso Robles Formation, and Careaga Sand. The alluvial terrace deposits are of Pleistocene age, are composed of unconsolidated sand, gravel, silt, and clay, and are located in the San Luis Obispo Valley and the Santa Ynez River Valley groundwater basins and in the uplands located just outside of the Santa Maria River Valley groundwater basin (California Department of Water Resources, 2004b, c, e). The Orcutt Formation of Pleistocene age, which may be classified as a terrace deposit, is primarily of fluvial origin and is composed of unconsolidated clay and sand interbedded with gravel (California Department of Water Resources, 2004c, d, e). The Paso Robles Formation is of Plio-Pleistocene age and consists of unconsolidated to poorly consolidated coarse sand and gravel, as well as finer sand, silt, and clay and some limestone that formed from deposition in floodplains and small lakes. The Careaga Sand is of Pliocene age and consists of unconsolidated fine- to medium-grained marine sand. The Careaga Sand generally underlies the Paso Robles Formation but is exposed in the San Luis Obispo Valley, the northern part of the Santa Maria River Valley, and the central part of the Santa Ynez River Valley groundwater basins (Upson and Thomasson, 1951; California Department of Water Resources, 2002, 2004b).

The area surrounding the study unit mostly consists of marine sediment of Miocene age (fig. 4). The area around the Los Osos Valley and San Luis Obispo Valley groundwater basins mostly consists of the Franciscan complex which may include some rocks of volcanic origin. Some volcanics of Tertiary age exist in the San Luis Range near Nipomo, and ultramafic and mafic rocks border the Uplands study area northeast of Solvang.

The SCRC study unit has three major faults zones (the Los Osos, Edna, and Santa Maria) that act as barriers to the lateral movement of groundwater from the surrounding mountains. A fourth fault, the Santa Ynez River Fault, does not restrict groundwater flows into the basins (Sylvester and Darrow, 1979; California Department of Water Resources, 2004a, b, c, d, e) (fig. 4). There also is a subsurface restrictive structure within the San Antonio Creek Valley groundwater basin that creates the wetland known as Barka Slough

(California Department of Water Resources, 2004c).

The water-bearing formations that serve as the primary aquifer system in the SCRC study unit are the alluvial deposits of non-marine and fluvial origin and of Holocene age, the Paso Robles Formation, and the Careaga Sand. The water-bearing units are underlain by much less permeable bedrock and granite of Tertiary and Cretaceous age (Valentine and others, 2001).

Groundwater recharge in the SCRC study unit occurs from a mixture of ambient recharge (percolation of precipitation, irrigation waters, and seepage from streams and rivers), subsurface inflow, and engineered recharge (urban and agricultural return water, treated wastewater, and lakes) (California Department of Water Resources, 2004a, b, c, d, e). Groundwater flow generally is westward toward the Pacific Ocean for all groundwater basins except San Luis Obispo Valley (fig. 5; Bright and others, 1992; California Department of Water Resources, 2002, 2004a, c, d, e; http://www.water. ca.gov/waterdatalibrary/groundwater/contour/index.cfm [water levels for February-April 2008, accessed January 6, 2012]). Groundwater flow in the San Luis Obispo Valley is eastward or westward but always toward San Luis Obispo Creek. The main source of groundwater discharge in the SCRC study unit is from groundwater pumping, used primarily for irrigation and secondarily for public water supply (California Department of Water Resources, 2004a, b, c, d, e). The cities of Arroyo Grande, Lompoc, San Luis Obispo, and Santa Maria get all or part of their water supply from groundwater (Water Education Foundation, 2006). Pumping depressions occur near Nipomo and west of Lompoc (California Department of Water Resources, 2002; http://www.water.ca.gov/waterdatalibrary/ groundwater/contour/index.cfm [water levels for FebruaryApril 2008, accessed January 6, 2012]). 


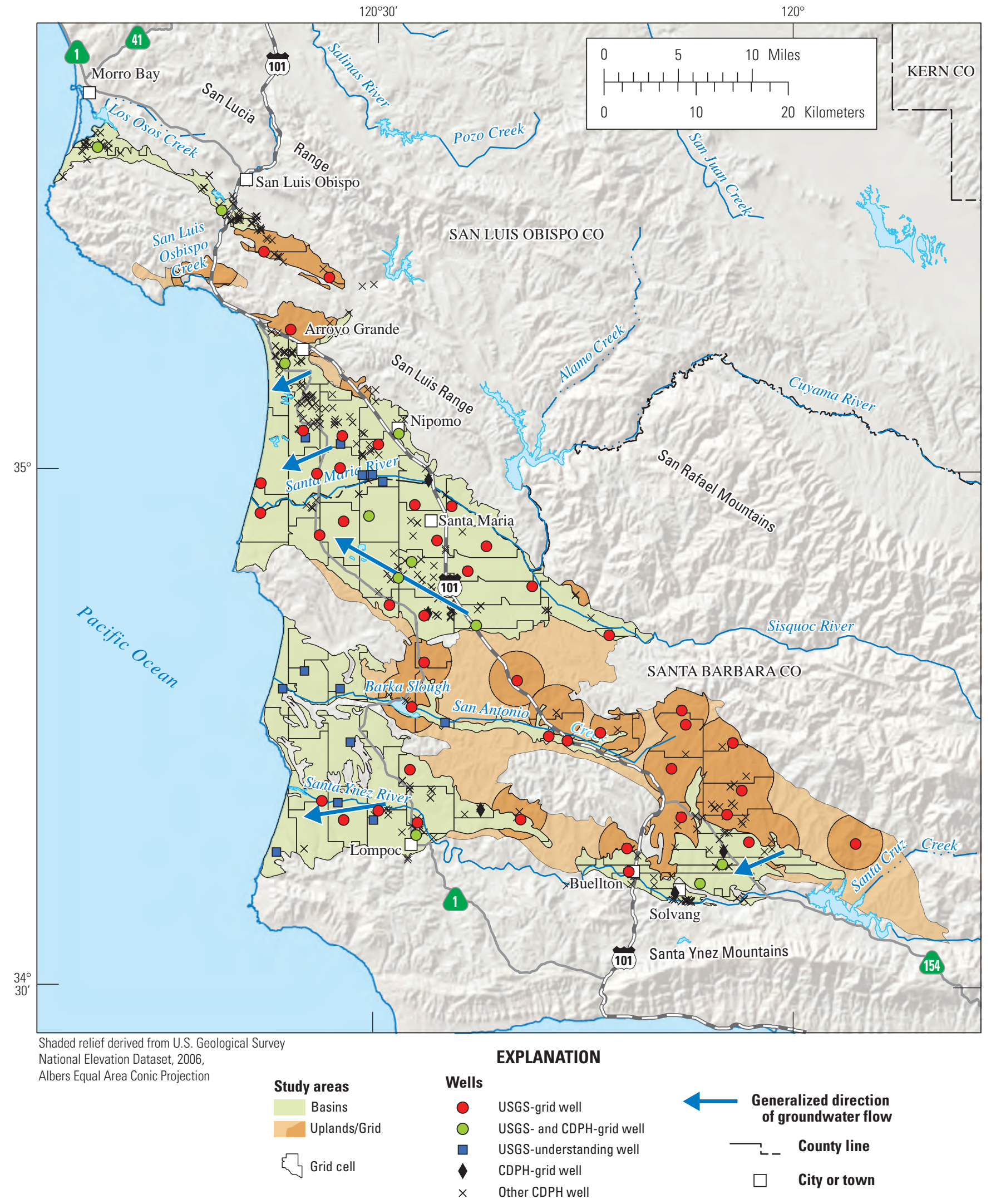

Figure 5. Grid cells, USGS-grid and USGS-understanding wells sampled during May-December 2008, California Department of Public Health (CDPH)-grid wells sampled for inorganic constituents, and generalized groundwater flow for the South Coast RangeCoastal study unit, California GAMA Priority Basin Project. 


\section{Methods}

The status assessment was designed to provide a spatially unbiased evaluation of the areal proportions of individual constituents and classes of constituents possibly affecting groundwater quality of the primary aquifer system. The understanding assessment was designed to identify the relation between observed groundwater quality and potential natural and human explanatory factors. This section describes the methods used for (1) defining groundwater quality,

(2) assembling the datasets used for the status assessment,

(3) determining which constituents warranted assessment,

(4) calculating aquifer-scale proportions, and (5) analyzing explanatory factors and water-quality datasets as part of the understanding assessment. Methods used for compilation of data on potential explanatory factors are described in appendix A.

The primary metric for defining groundwater quality is relative-concentration, which compares concentrations of constituents measured in groundwater to regulatory and non-regulatory benchmarks used to evaluate drinking-water quality. Constituents were selected for additional evaluation in the assessment based on objective criteria by using their relative-concentrations. Groundwater-quality data collected by the GAMA Priority Basin Project (Mathany and others, 2010) and data compiled in the CDPH database were used in the status assessment. Two statistical methods based on spatially unbiased equal-area grids were used to calculate aquifer-scale proportions of low, moderate, or high relative-concentrations: the "grid-based" method uses one value per cell to represent groundwater quality, and the "spatially weighted" method uses many values per cell (Belitz and others, 2010).

Priority Basin Project understanding assessments were designed to evaluate the natural and human factors that affect groundwater quality at the study-unit level. A finite set of potential explanatory factors was analyzed in relation to constituents of interest to place the observed water quality within the context of physical and chemical processes.

Nonparametric statistical tests were used to identify significant correlations between the constituents of interest and potential explanatory factors.

\section{Status Assessment Methods}

The status assessment included the following two steps. (1) Water-quality data were normalized to their respective water-quality benchmarks by calculating their relativeconcentrations (Toccalino and others, 2004; Toccalino and Norman, 2006), and (2) aquifer-scale proportions were determined for categories of "high," "moderate," and "low" relative-concentrations by using two methods: grid-based and spatially weighted. Results for the two approaches were compared, and results from the preferred approach were used to identify constituents of interest for further discussion.

\section{Relative-Concentrations and Water-Quality Benchmarks}

To provide context for water-quality data, measured concentrations of constituents may be compared to waterquality benchmarks that are typically applied to finished drinking water. Concentrations of constituents are presented as relative-concentrations in the status assessment section of this report:

$$
\text { Relative-concentration }=\frac{\text { Sample concentration }}{\text { Water-quality benchmark concentration }} \text {. }
$$

Toccalino and others (2004), Toccalino and Norman (2006), and Rowe and others (2007) used the ratio of measured concentration to a benchmark (either maximum contaminant levels [MCLs] or health-based screening levels [HBSLs]) and defined this ratio as the benchmark quotient. Benchmark quotients are relative-concentrations. Relativeconcentrations less than 1.0 indicate sample concentrations less than the benchmark, and values greater than 1.0 indicate sample concentrations greater than the benchmark. The use of relative-concentrations permits comparison of a wide range of concentrations for different constituents on a single scale.

In this report, the ratio of measured concentration to a water-quality benchmark is called a relative-concentration rather than a benchmark quotient because the benchmarks used to calculate relative-concentrations are not the same as the benchmarks used to calculate benchmark quotients for all constituents. Benchmark quotients are calculated using U.S. Environmental Protection Agency (USEPA) maximum contaminant levels (MCL-US) or USGS-USEPA HBSLs. HBSLs are determined using USEPA methodologies for establishing drinking-water guidelines, and the most recent USEPA peer-reviewed, publicly available humanhealth toxicity information (Toccalino, 2007). Relativeconcentrations are calculated using benchmarks established by the USEPA and CDPH (U.S. Environmental Protection Agency, 2006; California Department of Health Services, 2007). HBSLs were not used in this report because HBSLs are not currently used as benchmarks by California drinking-water regulatory agencies.

Regulatory and non-regulatory benchmarks apply to water that is served to the consumer, not to untreated groundwater. The benchmarks used for each constituent were selected in the following order of priority:

1. Regulatory, in the order of health-based USEPA and CDPH maximum contaminant levels (MCL-US and MCL-CA), USEPA action levels (AL-US), and USEPA treatment technique levels (TT-US). Federal benchmarks were used unless the California levels were lower.

2. Non-regulatory USEPA and CDPH secondary maximum contaminant levels (SMCL-US and SMCL-CA). For constituents with recommended and upper SMCL-CA levels, the values for the upper levels were used. 
3. Non-regulatory, in the order of health-based CDPH notification levels (NL-CA), USEPA lifetime health advisory levels (HAL-US) and USEPA risk-specific dose (1 in 100,000 lifetime risk of cancer, RSD5-US).

Note that for constituents with multiple types of benchmarks, this hierarchy may not result in selection of the benchmark with the lowest concentration. Additional information on the types of benchmarks and the benchmarks for all constituents analyzed is provided by Mathany and others (2010).

Relative-concentrations were classified into high, moderate, and low categories:

\begin{tabular}{lcc}
\hline \multicolumn{1}{c}{ Category } & $\begin{array}{c}\text { Relative-concentrations for } \\
\text { organic constituents }\end{array}$ & $\begin{array}{c}\text { Relative-concentrations for } \\
\text { inorganic constituents }\end{array}$ \\
\hline High & $>1$ & $>1$ \\
Moderate & $>0.1$ and $\leq 1$ & $>0.5$ and $\leq 1$ \\
Low & $\leq 0.1$ & $\leq 0.5$ \\
\hline
\end{tabular}

A relative-concentration greater than 1.0 is classified as high, indicating the concentration is greater than the benchmark concentration. A relative-concentration of 0.1 was used as a boundary between moderate and low values of organic and special-interest constituents for consistency with other studies and reporting requirements (Toccalino and others, 2004). The USEPA also established a relativeconcentration of 0.1 of the regulatory benchmark as a threshold concentration so that the agency would be notified if the presence of a pesticide in surface water or groundwater is greater than or equal to that threshold (U.S. Environmental Protection Agency, 1997). In addition, organic and specialinterest constituents, which generally are anthropogenic, usually are less prevalent and have smaller maximum relative-concentrations than inorganic constituents. In contrast, inorganic constituents are typically naturally occurring at concentrations that could be greater than 0.1 of regulatory benchmarks; consequently, it would be difficult, or potentially misleading, to identify inorganic constituents that may have elevated concentrations greater than background levels if a relative-concentration of 0.1 was used as the threshold between moderate and low relative-concentrations. Therefore, the boundary between moderate and low relativeconcentrations was set at 0.5 of the regulatory benchmark for inorganic constituents.

\section{Design of Sampling Networks for Status Assessment}

The wells selected for sampling by the USGS in the SCRC study provide a statistically unbiased, spatially distributed set of wells for the assessment of the quality of groundwater in the primary aquifer system (USGS-grid wells). Water-quality data from the USGS-grid wells were supplemented with data from selected wells in the CDPH database (CDPH-grid wells; see the "California Department of Public Health Grid Well Selection" section) to obtain more complete spatial coverage and to include constituents that were not analyzed for in every USGS-grid well. These data were used to assess proportions of the primary aquifer system with high, moderate, and low relative-concentrations.

The primary data used for the grid-based calculations of aquifer-scale proportions were data from wells sampled by the GAMA Priority Basin Project. Detailed descriptions of the methods used to identify wells for sampling are given in Mathany and others (2010). USGS-grid wells (39 wells in the Basins study area and 16 wells in the Uplands study area) were selected to provide a statistically unbiased and spatially distributed set of wells for the assessment of the quality of groundwater in the primary aquifer system (Scott, 1990). The SCRC study unit was divided into equal-area grid cells of approximately $10 \mathrm{mi}^{2}\left(25 \mathrm{~km}^{2}\right)$. The objective of the grid design was to sample one CDPH well in each cell. If a grid cell did not contain accessible CDPH wells, then commercial, irrigation, or domestic wells were considered for sampling. The USGS-grid wells were sampled by the USGS for the GAMA Priority Basin Project, but are owned by other organizations or individuals.

One USGS-grid well was sampled in 55 of the 61 grid cells in the SCRC study unit, including 39 of the 45 grid cells in the Basins study area and all 16 grid cells in the Uplands study area (fig. 5). The grid cells from which samples were not collected had few, if any, wells, or permission to sample was not granted for wells in those cells. The 55 USGS-grid wells sampled in the SCRC study unit included $31 \mathrm{CDPH}$ wells, 20 irrigation wells, 2 industrial wells, 1 domestic well, and 1 monitoring well. The irrigation, industrial, domestic, and monitoring wells had depth of perforations within the range of the depth of perforations for CDPH wells located in the SCRC study unit. The CDPH wells, irrigation wells, industrial wells, and domestic well are considered production wells for this report. USGS-grid wells in the SCRC study unit were numbered in the order of sample collection with the prefix varying by study area: Basins study area, SCRC-B and Uplands study area, SCRC-H (igg. A1, table A1). 
Samples collected from USGS-grid wells were analyzed for 220 to 289 constituents, depending on the particular sampling schedule(s) used for the well (table 1). The fast and slow analytical schedules refer to the amount of time required for a field crew to complete all work at a well. Samples from all wells were analyzed for VOCs, pesticides, perchlorate, noble gases, tritium, and stable isotopes of hydrogen and oxygen. Samples from 32 USGS-grid wells and 7 understanding wells were analyzed for pharmaceuticals, $\mathrm{N}$-nitrosodimethylamine (NDMA), major and minor ions, trace elements, nutrients, dissolved organic carbon, gross alpha and beta radioactivity, carbon isotopes, and arsenic and iron species. In addition, samples from six USGS-grid wells and six USGS-understanding wells were analyzed for dissolved gases, stable isotopes of nitrogen and oxygen in nitrate, and stable isotopes of nitrogen in dissolved nitrogen gas. The collection, analysis, and quality-control data for the analytes listed in table 1 are described by Mathany and others (2010) except for stable isotopes of nitrogen in dissolved nitrogen gas which are described in appendix E.

\section{California Department of Public Health Grid Well Selection}

Samples for analysis of inorganic constituents on the slow or special study schedules were collected from 32 to 36 of the 55 USGS-grid wells (table 2). Because the GAMA Priority Basin Project did not collect samples for analysis of a complete suite of inorganic constituents for all grid cells, the CDPH database was used to provide data for inorganic constituents for the cells without these data (table 2). In addition, the GAMA Priority Basin Project was not able to sample wells in six of the grid cells. CDPH wells were selected to represent as many of these grid cells as possible. CDPH wells that were selected to supplement USGS-grid wells are referred to as "CDPH-grid" wells. The approach used to identify suitable CDPH wells is described in appendix A. Briefly, the first choice was to use CDPH data from the same well as the USGS-grid well ("DG" CDPH-grid wells; table A1). If the DG well did not have all needed data, a second well was randomly selected from the subset of CDPH wells in the same cell with data ("DPH" CDPH-grid wells; table A1). Combining data from CDPH-grid wells with data from USGS-grid wells produced inorganic data for 44 cells (56 cells for total dissolved solids). All other CDPH wells with data from the current period (May 20, 2005, through May 19, 2008) not selected to be CDPH-grid wells are referred to as "CDPH-other" wells. Comparisons of data from USGS and $\mathrm{CDPH}$ wells to assess the validity of using these different sources in combination are presented in appendix B.

Samples for analysis of VOCs, pesticides, and perchlorate were collected at all USGS-grid wells. More VOCs and pesticides were analyzed by the GAMA Priority Basin Project than were available in the CDPH database (table 3). Where data were available from both databases, organic constituents analyzed in samples collected as part of the GAMA Priority Basin Project were selected for data interpretation largely because of lower laboratory reporting levels of the GAMA Priority Basin Project data, typically by one or two orders of magnitude, relative to the method detection limits (MDLs) used for analyses compiled by the CDPH (table 3).

Low-level analyses of VOCs and pesticides may be used as tracers of groundwater that has recharged since these compounds began to be used for industrial and commercial purposes. Low-level analyses provide an early awareness of constituents whose presence in groundwater at low concentrations may be important for the prioritization of monitoring water quality in the future.

\section{Selection of Constituents for Additional Evaluation}

The GAMA Priority Basin Project used available monitoring data along with newly collected data for characterization of the groundwater resource. The statewide CDPH database contains data for regulated constituents with water-quality benchmarks. Although other organizations in California also collect water-quality data, the CDPH has the only statewide database of public-supply well data available for comprehensive analysis. Data for some constituents, including VOCs, pesticides, inorganic constituents, and radioactive constituents, are available from the GAMA Priority Basin Project and the CDPH databases. Both datasets are used in the status and understanding assessments. The CDPH database contains more than 200,000 records from more than 500 wells in the SCRC study unit, necessitating targeted retrievals to access water-quality data effectively. CDPH data were used with USGS-grid data to identify constituents in the study unit at concentrations greater than water-quality benchmarks at any time during the period of record (January 18, 1984, through May 19, 2008).

More than 300 constituents were analyzed in the SCRC study unit; however, only a subset of these constituents was selected for additional evaluation in this report. Three criteria were used to identify constituents for additional evaluation in the status assessment:

1. Constituents with concentrations at high or moderate relative-concentrations in the CDPH database during the current 3-year period (May 20, 2005, to May 19, 2008),

2. Constituents with concentrations at high or moderate relative-concentrations in the USGS-grid wells or USGSunderstanding wells, or

3. Organic constituents having detection frequencies greater than 10 percent in the USGS-grid well dataset for a given study unit, even if relative-concentrations were low. 


\section{Status and Understanding of Groundwater Quality in the South Coast Range-Coastal Study Unit, 2008}

Table 1. Analytes and wells sampled for each analytical schedule for the South Coast Range-Coastal study unit, California GAMA Priority Basin Project, May-November 2008.

[GAMA, Groundwater Ambient Monitoring and Assessment Program; -, no data]

\begin{tabular}{|c|c|c|c|}
\hline \multirow{2}{*}{ Number of wells } & \multicolumn{3}{|c|}{ Sampling schedule ${ }^{1}$} \\
\hline & Fast & Slow & Special study ${ }^{2}$ \\
\hline Total number of wells & 31 & 39 & 13 \\
\hline Number of understanding wells sampled & 8 & 7 & 7 \\
\hline Analyte groups & \multicolumn{3}{|c|}{ Number of constituents } \\
\hline Dissolved oxygen and $\mathrm{pH}$ & 2 & 2 & - \\
\hline Field alkalinity, bicarbonate, and carbonate & - & 3 & - \\
\hline \multicolumn{4}{|l|}{ Organic constituents } \\
\hline Volatile organic compounds (VOCs) ${ }^{3}$ & 85 & 85 & - \\
\hline Dissolved organic carbon & - & 1 & - \\
\hline \multicolumn{4}{|l|}{ Constituents of special interest } \\
\hline Perchlorate & 1 & 1 & - \\
\hline $\mathrm{N}$-Nitrosodimethylamine (NDMA) & - & 1 & - \\
\hline \multicolumn{4}{|l|}{ Inorganic constituents } \\
\hline Trace elements, major and minor ions, and total dissolved solids (TDS) & - & 36 & - \\
\hline Nutrients & - & 5 & 5 \\
\hline Arsenic and iron species & - & 4 & - \\
\hline \multicolumn{4}{|l|}{ Isotopes } \\
\hline Stable isotopes of hydrogen and oxygen & 2 & 2 & - \\
\hline Noble gases and tritium & 7 & 7 & - \\
\hline Gross alpha and beta radioactivity ${ }^{4}$ & - & 4 & - \\
\hline Total & 220 & 289 & 13 \\
\hline
\end{tabular}

${ }^{1}$ Fast and slow analytical schedules refer to the amount of time required for a field crew to complete all work at a well.

${ }^{2}$ Special study analytes were added to 10 wells on the slow schedule and 3 wells on the fast schedule.

${ }^{3}$ Includes nine constituents classified as fumigants or fumigant synthesis byproducts.

${ }^{4}$ Both gross alpha and gross beta particle activities were measured after 72-hour and 30-day holding times; the 30-day results are used in this report. 
Table 2. Inorganic constituents, associated benchmark information, and number of grid wells per constituent, South Coast RangeCoastal study unit, California GAMA Priority Basin Project.

[CDPH, California Department of Public Health; GAMA, Groundwater Ambient Monitoring and Assessment Program; MCL-CA, California Department of Public Health (CDPH) maximum contaminant level; MCL-US, U.S. Environmental Protection Agency (USEPA) maximum contaminant level; SMCL-CA, CDPH secondary maximum contaminant level; NL-CA, CDPH notification level; AL-US, USEPA action level; HAL-US, USEPA lifetime health advisory level; USGS, U.S. Geological Survey; mg/L, milligrams per liter; $\mu \mathrm{g} / \mathrm{L}$, micrograms per liter; pCi/L, picocuries per liter]

\begin{tabular}{|c|c|c|c|c|c|}
\hline Constituent & $\begin{array}{c}\text { Benchmark } \\
\text { type }\end{array}$ & $\begin{array}{l}\text { Benchmark } \\
\text { value }\end{array}$ & $\begin{array}{l}\text { Benchmark } \\
\text { unit }\end{array}$ & $\begin{array}{l}\text { Number of grid } \\
\text { wells sampled by } \\
\text { USGS GAMA }\end{array}$ & $\begin{array}{l}\text { Number of grid wells } \\
\text { with data selected } \\
\text { from CDPH }\end{array}$ \\
\hline \multicolumn{6}{|c|}{ Nutrients with health-based benchmarks } \\
\hline Ammonia, as nitrogen & HAL-US & ${ }^{1} 24.7$ & $\mathrm{mg} / \mathrm{L}$ & ${ }^{2} 36$ & 0 \\
\hline Nitrate plus nitrite, as nitrogen & MCL-US & 10 & $\mathrm{mg} / \mathrm{L}$ & ${ }^{2} 36$ & 13 \\
\hline Nitrite, as nitrogen & MCL-US & 1 & $\mathrm{mg} / \mathrm{L}$ & ${ }^{2} 36$ & 10 \\
\hline Aluminum & MCL-CA & 1,000 & $\mu \mathrm{g} / \mathrm{L}$ & 32 & 12 \\
\hline Antimony & MCL-US & 6 & $\mu g / L$ & 32 & 12 \\
\hline Arsenic & MCL-US & 10 & $\mu g / L$ & 32 & 12 \\
\hline Barium & MCL-CA & 1,000 & $\mu \mathrm{g} / \mathrm{L}$ & 32 & 12 \\
\hline Beryllium & MCL-US & 4 & $\mu \mathrm{g} / \mathrm{L}$ & 32 & 12 \\
\hline Copper & AL-US & 1,300 & $\mu g / L$ & 32 & 12 \\
\hline Lead & AL-US & 15 & $\mu g / L$ & 32 & 12 \\
\hline Mercury & MCL-US & 2 & $\mu \mathrm{g} / \mathrm{L}$ & 30 & 12 \\
\hline Molybdenum & HAL-US & 40 & $\mu \mathrm{g} / \mathrm{L}$ & 32 & 0 \\
\hline Nickel & MCL-CA & 100 & $\mu \mathrm{g} / \mathrm{L}$ & 32 & 12 \\
\hline Selenium & MCL-US & 50 & $\mu \mathrm{g} / \mathrm{L}$ & 32 & 12 \\
\hline Strontium & HAL-US & 4,000 & $\mu \mathrm{g} / \mathrm{L}$ & 32 & 0 \\
\hline Thallium & MCL-US & 2 & $\mu \mathrm{g} / \mathrm{L}$ & 32 & 12 \\
\hline Vanadium & NL-CA & 50 & $\mu \mathrm{g} / \mathrm{L}$ & 32 & 8 \\
\hline Chloride & SMCL-CA & 500 & $\mathrm{mg} / \mathrm{L}$ & 35 & 12 \\
\hline Sulfate & SMCL-CA & 500 & $\mathrm{mg} / \mathrm{L}$ & 35 & 12 \\
\hline Total dissolved solids (TDS) & SMCL-CA & 1,000 & $\mathrm{mg} / \mathrm{L}$ & ${ }^{3} 43$ & 12 \\
\hline \multicolumn{6}{|c|}{ Radioactive constituents with health-based benchmarks } \\
\hline Gross alpha radioactivity & MCL-US & 15 & $\mathrm{pCi} / \mathrm{L}$ & 32 & 8 \\
\hline Gross beta radioactivity & MCL-CA & 50 & $\mathrm{pCi} / \mathrm{L}$ & 32 & 0 \\
\hline Uranium & MCL-US & 30 & $\mu \mathrm{g} / \mathrm{L}$ & 32 & 4 \\
\hline
\end{tabular}

${ }^{1}$ The HAL-US is $30 \mathrm{mg} / \mathrm{L}$ "as ammonia.” To facilitate comparison to the analytical results, we have converted and reported this HAL-US as $24.7 \mathrm{mg} / \mathrm{L}$ "as nitrogen."

${ }^{2}$ One well was a CDPH grid well (SCRC-DPH-B25) and a USGS-understanding well (SCRC-U04).

${ }^{3}$ TDS concentrations for eight wells were calculated from specific conductance data. 
Table 3. Comparison of the number of compounds and median method detection levels or laboratory reporting levels by constituent class for data stored in the California Department of Public Health (CDPH) database and for data collected by the U.S. Geological Survey in the South Coast Range-Coastal study unit, California GAMA Priority Basin Project, May-November 2008.

[GAMA, Groundwater Ambient Monitoring and Assessment Program; MDL, method detection limit; LRL, laboratory reporting level; mg/L, milligrams per liter; $\mu \mathrm{g} / \mathrm{L}$, micrograms per liter; $\mathrm{pCi} / \mathrm{L}$, picocuries per liter; $\mathrm{ssL}_{\mathrm{c}}$, sample-specific critical level; nc, not collected]

\begin{tabular}{|c|c|c|c|c|c|}
\hline \multirow{2}{*}{$\begin{array}{c}\text { Constituent } \\
\text { type }\end{array}$} & \multicolumn{2}{|c|}{ CDPH } & \multicolumn{2}{|c|}{ GAMA } & \multirow{2}{*}{$\begin{array}{l}\text { Concentration } \\
\text { or activity } \\
\text { units }\end{array}$} \\
\hline & $\begin{array}{l}\text { Number of } \\
\text { compounds }\end{array}$ & $\begin{array}{c}\text { Median } \\
\text { MDL }\end{array}$ & $\begin{array}{l}\text { Number of } \\
\text { compounds }\end{array}$ & $\begin{array}{c}\text { Median } \\
\text { LRL }\end{array}$ & \\
\hline Volatile organic compounds plus gasoline oxygenates (including fumigants) & 73 & 0.5 & 85 & 0.06 & $\mu \mathrm{g} / \mathrm{L}$ \\
\hline Pesticides plus degradates & 70 & 1 & 121 & 0.040 & $\mu \mathrm{g} / \mathrm{L}$ \\
\hline Pharmaceuticals & nc & nc & 13 & 0.030 & $\mu g / L$ \\
\hline$N$-Nitrosodimethylamine (NDMA) & 1 & unknown & 1 & 0.002 & $\mu \mathrm{g} / \mathrm{L}$ \\
\hline Trace elements & 21 & 6 & 25 & 0.12 & $\mu \mathrm{g} / \mathrm{L}$ \\
\hline Radioactive constituents ( $\mathrm{ssL}_{\mathrm{c}}$ ) & 6 & 1 & 4 & ${ }^{1} 1.10$ & $\mathrm{pCi} / \mathrm{L}$ \\
\hline Nutrients, dissolved organic carbon & 6 & 0.4 & 6 & 0.05 & $\mathrm{mg} / \mathrm{L}$ \\
\hline Major and minor ions & 10 & unknown & 11 & 0.10 & $\mathrm{mg} / \mathrm{L}$ \\
\hline
\end{tabular}

${ }^{1}$ Value reported is a median sample-specific critical level $\left(\mathrm{ssL}_{\mathrm{c}}\right)$ for four radioactive constituents collected and analyzed by GAMA.

A complete list of the constituents investigated by the GAMA Priority Basin Project in the SCRC study unit may be found in the data report (Mathany and others, 2010).

The CDPH database was used to identify constituents that have been reported at high relative-concentrations historically but not currently (table 4). The historical period was defined as the period starting with the earliest record maintained in the CDPH electronic database and ending just prior to the 3-year interval used for the status assessment (January 18, 1984, to May 19, 2005). Constituent concentrations retrieved from the CDPH database for samples in the study unit were identified as "historically high" (table 4) if concentrations were high (greater than benchmarks) before the current period but not high during the current period or in USGS-grid data. Historically high constituents that do not otherwise meet the criteria for additional evaluation in the status assessment were not considered representative of potential groundwaterquality concerns in the study unit during the current period. Constituents may be historically high but not currently high because of improvement of groundwater quality with time or abandonment of wells with high concentrations of constituents.

\section{Calculation of Aquifer-Scale Proportions}

The status assessment is intended to characterize the quality of groundwater resources in the primary aquifer system of the SCRC study unit. The primary aquifer system is defined by the depth intervals over which wells listed in the CDPH database are perforated. The use of the term "primary aquifer system" does not imply that there is a discrete aquifer unit. In most groundwater basins, municipal and community supply wells generally are perforated at greater depths than are domestic wells. Most of the wells used in the status assessment are listed in the CDPH databases. Thus, because domestic wells are not listed in the CDPH database, the primary aquifer system generally corresponds to the part of the aquifer system tapped by municipal and community supply wells. Depths of CDPH wells in the SCRC study unit typically range from 265 to $630 \mathrm{ft}$ below land surface (bls); top-of-perforations typically range from 115 to $350 \mathrm{ft}$ bls.

Water quality in the primary aquifer system can differ from water quality in shallow or deep parts of the aquifer system. Previous investigations in the study unit have shown that groundwater in shallow parts of the aquifer in the Santa Ynez River Valley groundwater basin generally is of poorer quality than groundwater at greater depths in the aquifer (Hamlin, 1985; Bright and others, 1992). A report for the northern part of the Santa Maria River Valley groundwater basin indicates that groundwater quality varies with depth in some areas, but not in others (California Department of Water Resources, 2002). An earlier study in the Santa Maria River Valley groundwater basin did not demonstrate differences in water quality with depth (Worts, 1951). The aquifer-scale proportions discussed in this report do not characterize water quality in parts of the aquifer system that are more shallow than or deeper than the primary aquifer system.

Two statistical methods_-grid-based and spatially weighted - were applied to evaluate the proportions of the primary aquifer system in the SCRC study unit with high, moderate, and low relative-concentrations of constituents. For ease of discussion, these proportions are referred to as "high," "moderate," and "low" aquifer-scale proportions. Calculations of aquifer-scale proportions were made for individual constituents meeting the criteria for additional evaluation in the status assessment, and for classes of constituents. Classes of constituents with health-based benchmarks included trihalomethanes (THMs), solvents, other VOCs, pesticides, 
Table 4. Constituents in California Department of Public Health (CDPH) wells with historically high concentrations but not high during the current period (May 20, 2005, to May 19, 2008) in the South Coast Range-Coastal study unit, California GAMA Priority Basin Project.

[A high analysis is defined as a concentration that is greater than the human-health benchmark for that constituent. Abbreviations CDPH, California Department of Public Health; GAMA, Groundwater Ambient Monitoring and Assessment Program; MCL-US; U.S. Environmental Protection Agency (USEPA) maximum contaminant level; MCL-CA, CDPH maximum contaminant level; NL-CA, CDPH notification level; $\mathrm{pCi} / \mathrm{L}$, picocuries per liter; $\mu \mathrm{g} / \mathrm{L}$, micrograms per liter]

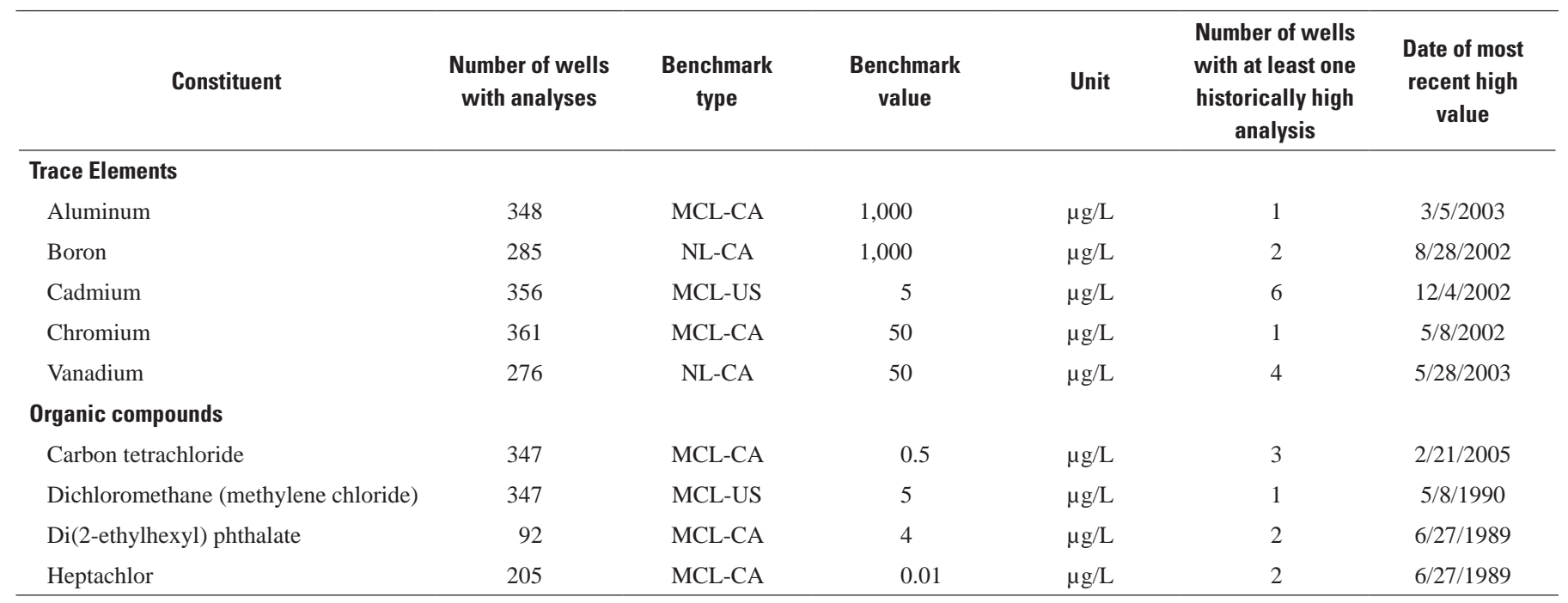

trace elements and minor ions, radioactive constituents, and nutrients. Among constituents with aesthetic benchmarks (SMCLs), aquifer-scale proportions were calculated for major ions (total dissolved solids, chloride, and sulfate) in addition to manganese and iron.

The grid-based calculation uses the grid-well dataset assembled from the USGS- and CDPH-grid wells (Belitz and others, 2010). The areal proportion of the primary aquifer system with high relative-concentrations of a constituent was calculated by dividing the number of grid cells represented by a high value for that constituent by the total number of grid cells with data for that constituent (see appendix $\mathrm{C}$ for details of methods). Areal proportions of moderate and low relative-concentrations were calculated similarly. Confidence intervals for grid-based detection frequencies of high relativeconcentrations were computed using the Jeffreys interval for the binomial distribution (Brown and others, 2001). Although the grid-based estimate is spatially unbiased, the grid-based approach may not detect constituents that are present at high relative-concentrations in small proportions of the primary aquifer system. For calculation of high aquifer-scale proportion for a class of constituents, cells were considered high if the value for any of the constituents in that particular class was high. Cells were considered moderate if the relativeconcentration for any of the constituents was moderate, but none of the relative-concentrations were high.

The spatially weighted calculation used all available data from the following sources to calculate the aquifer-scale proportions - (1) all CDPH wells in the study unit (most recent analysis from each well with data for the constituent available during the current period, May 20, 2005, to May 19, 2008, (2) USGS-grid wells, and (3) USGS-understanding wells with perforation intervals representative of the primary aquifer system. USGS-understanding wells that were monitoring wells were excluded because these wells were perforated at shallower depths than is typical for wells in the CDPH database. For the spatially weighted approach, areal proportions were computed on a cell-by-cell basis (Isaaks and Srivastava, 1989; Belitz and others, 2010). The areal proportion of high relative-concentrations for each constituent for the primary aquifer system was computed (1) by computing the proportion of wells with high relativeconcentrations in each grid cell and (2) by calculating the average of the grid-cell proportions computed in step (1) (see appendix $C$ for details of methods). Similar procedures were used to calculate the aquifer-scale proportions of moderate and low relative-concentrations. The resulting proportions are spatially unbiased (Isaaks and Srivastava, 1989).

Raw detection frequencies of constituents with high relative-concentrations, calculated using the same data used for the spatially weighted approach, are provided for reference in this report, but were not used to assess aquifer-scale proportions. Wells are not uniformly distributed throughout the study area; therefore, the frequency of encountering a well with high relative-concentrations is spatially biased. For example, high relative-concentrations in spatially clustered wells in a particular area representing a small part of the primary aquifer system could be given a disproportionately higher weight compared to spatially unbiased methods.

The grid-based aquifer-scale proportions were used to represent proportions in the primary aquifer system unless the spatially weighted proportions were significantly different from the grid-based values. Significantly different results were defined as follows: 
1. If the grid-based high aquifer-scale proportion was zero and spatially weighted aquifer-scale proportion was nonzero, then the spatially weighted result was used. This situation can arise when the concentration of a constituent is high in a small fraction of the aquifer.

2. If the grid-based high aquifer-scale proportion was nonzero, then the 90 percent confidence interval (based on the Jeffreys interval for the binomial distribution, Brown and others, 2001) was used to evaluate the difference. If the spatially weighted proportion was outside the 90 percent confidence interval, then the spatially weighted proportion was used.

The grid-based method to evaluate the aquifer-scale proportion of moderate and low relative-concentrations was used in most cases because the reporting limits for many organic constituents and some inorganic constituents in the CDPH database were higher than the boundary between the moderate and low categories. However, if the grid-based moderate proportion was zero and the spatially weighted proportion non-zero, then the spatially weighed value was used as an estimate for the moderate proportion.

\section{Calculation of Gross Alpha Radioactivity, Uranium, and Total Dissolved Solids}

The MCL-US (15 picocuries per liter [pCi/L]) for gross alpha particle activity applies to adjusted gross alpha activity, which is equal to the measured gross alpha activity minus uranium activity (U.S. Environmental Protection Agency, 2009). Gross alpha is used a screening tool to determine whether other radioactive constituents must be analyzed. For regulatory purposes, analysis of uranium is only required if gross alpha activity is greater than $15 \mathrm{pCi} / \mathrm{L}$; as a result, it is not always possible to calculate adjusted gross alpha activity. For this reason, gross alpha data without correction for uranium were the primary data used in this report.

Examination of data from samples having USGS-GAMA data for uranium and gross alpha indicated that, in the absence of data for uranium, uncorrected gross alpha data likely provide a more accurate estimate of the aquifer-scale proportions for uranium and radioactive constituents as a class than does adjusted gross alpha (Miranda Fram, USGS California Water Science Center, written commun., 2012).

USGS-GAMA reports data for gross alpha particle activity counted at 72 hours and at 30 days after sample collection. Regulatory sampling for gross alpha activity permits use of quarterly composite samples (U.S. Environmental Protection Agency, 2000; California Department of Public Health, 2012); thus, the USGS-GAMA gross alpha 30-day count data may be more appropriate to use when combining USGS-GAMA and CDPH datasets. Gross alpha activity in a groundwater sample may change with time after sample collection due to radioactive decay and ingrowth (activity may increase or decrease depending on sample composition and holding time) (Arndt, 2010).

Most data for uranium in the CDPH database are reported as activities in units of picocuries per liter, and the majority of uranium data gathered by USGS-GAMA are reported as concentrations in units of micrograms per liter. The factor used to convert uranium mass concentration to uranium activity depends on the isotopic composition of the uranium (U.S. Environmental Protection Agency, 2000). This report uses a conversion factor of 0.79 (Wong and others, 1999).

For USGS- and CDPH-grid wells without measured total dissolved solids (TDS) concentrations, TDS was estimated from specific conductance (SC) by using a linear regression equation, which was developed from measured SC and TDS data for 35 USGS-grid and understanding wells. Generally, SC follows a linear relation with TDS, and SC data were available for all 55 USGS-grid and 15 USGS-understanding wells, whereas laboratory-measured TDS data (as residue on evaporation) were available for only 35 of these wells. The predicted TDS using the regression equation (TDS = [0.748*SC]-54.12) closely matched measured TDS $\left(\mathrm{R}^{2}>\right.$ $0.97)$.

\section{Understanding Assessment Methods}

The understanding assessment was based on USGS- and CDPH-grid wells and USGS-understanding wells (figs. 5 and A1). Constituents discussed in the status assessment were selected for the understanding assessment if relativeconcentrations were considered high in more than 2 percent of the primary aquifer system, or, for organics, were detected in more than 10 percent of the USGS-grid well dataset. These constituents were selected to focus the assessment for understanding on those constituents that have the greatest effect on groundwater quality. CDPH-other wells were not used in the understanding assessment because data for many of the potential explanatory factors were not available (for example, tritium, dissolved oxygen, and well construction information).

The potential explanatory factors-land use, well depth, depth to the top-of-perforations, classified groundwater age, and geochemical condition (see appendix D for more details) - were analyzed in relation to constituents selected for additional evaluation for the understanding assessment to establish context for physical and chemical processes within the groundwater system. Statistical tests were used to identify significant correlations between the constituents of interest and potential explanatory factors. Graphs, bar charts, and maps were used to improve the understanding of factors affecting water quality for selected constituents with correlations to explanatory factors. 


\section{U.S. Geological Survey Understanding Wells}

Fifteen wells (USGS-understanding wells) were selected for sampling by the USGS to increase the data density in some areas to assess spatial changes in water quality. The USGS-understanding wells sampled in the SCRC study unit were identified with a prefix modified from those used for the USGS-grid wells (SCRC-U) and numbered 01 through 15.

The USGS-understanding wells were selected on the basis of two design objectives: (1) to assess changes in water quality along groundwater flow paths across parts of the Santa Maria River Valley groundwater basin and the Santa Ynez River Valley groundwater basin, and (2) to assess the water quality in the near-ocean aquifer in the Santa Ynez River Valley and San Antonio Creek Valley groundwater basins. The understanding wells included eight irrigation wells, six monitoring wells, and one CDPH well.

\section{Statistical Analysis}

Nonparametric statistical methods were used to test the significance of correlations between water-quality parameters and potential explanatory variables. Nonparametric statistics are robust techniques that generally are not affected by outliers and do not require that the data follow any particular distribution (Helsel and Hirsch, 2002). The significance level (p) used for hypothesis testing for this report was compared to a threshold value $(\alpha)$ of 5 percent $(\alpha=0.05)$ to evaluate whether the relation was statistically significant $(p<\alpha)$. Two different types of statistical tests were used because the set of potential explanatory factors included both continuous and categorical variables. Relations between categorical variables (for example, classified groundwater age or land-use class) and water-quality variables were evaluated using the Wilcoxon rank-sum or Kruskal-Wallis nonparametric tests. Correlations between continuous variables were evaluated by using Spearman's method. Correlations between potential explanatory factors, between water-quality parameters, and between potential explanatory factors and water-quality constituents were tested for significance.

Correlations between explanatory factors and groundwater constituents were tested by using either the set of USGS- and CDPH-grid wells plus USGS-understanding wells or USGS- and CDPH-grid wells only. Because the USGS-understanding wells represented relatively shallow groundwater or were in agricultural areas that were not randomly selected on a spatially distributed grid, they were excluded from analysis of relations between water quality and areally distributed explanatory variables (such as land use and study area) to avoid areal-clustering bias. However, USGSunderstanding wells were included in analysis of relations between water-quality constituents and vertically distributed explanatory factors (such as well depth, classified groundwater age, and oxidation-reduction characteristics).

\section{Potential Explanatory Factors}

A brief description of potential explanatory factors including land use, well depth, septic system density, formerly leaking underground fuel tanks (LUFTs), groundwater age, and geochemical conditions is given in this section. The data sources and methodology used for assigning values for potential explanatory factors are described in appendix D.

\section{Land Use}

Land use was quantified as the percentage of three land-use types: natural, agricultural, and urban. Land-use percentages were calculated for study units, study area, and within a 500-meter $(\mathrm{m})$ radius around wells (Johnson and Belitz, 2009).

Land use in the SCRC study unit is 61 percent natural, 29 percent agricultural, and 10 percent urban (figs. 3 and $\underline{6 B}$; Nakagaki and others, 2007). Land use in the areas surrounding the SCRC primarily is natural (fig. 3). In contrast, within the $500-\mathrm{m}(1,640-\mathrm{ft})$ radius around each grid well, the average land use was 47 percent natural, 32 percent agricultural, and 21 percent urban (fig. 6 ). The average natural land use was lower and the average urban land use was higher within the $500-\mathrm{m}$ radius around each grid well than for the study unit (fig. 6B). Within the 500-m (1,640-ft) radius around each $\mathrm{CDPH}$ well, the average agricultural land use was lower than that for the SCRC study unit or for the grid wells (25 percent), and urban land-use was higher than that for the study unit or for the grid wells (33 percent) (fig. 6B). In general, the land use around the grid wells in the SCRC study unit overrepresent the urban land use and under-represent the natural land use but are closer to the average land use of the study unit than land use around the CDPH wells.

Land use in the Uplands study area is 85 percent natural, 11 percent agricultural, and 4 percent urban; land use in the Basins study area is 52 percent natural, 36 percent agricultural, and 12 percent urban (fig. 6B). Within the 500-m radius around each well, the average land use around Upland grid wells was about the same as in the Uplands area, but the average land use around Basins grid wells had higher agricultural (41 percent) and urban (28 percent) land use than the Basins study area. In general, the Basins study area was more developed than the Uplands study area on the basis of the percentages of agricultural and urban land use. 

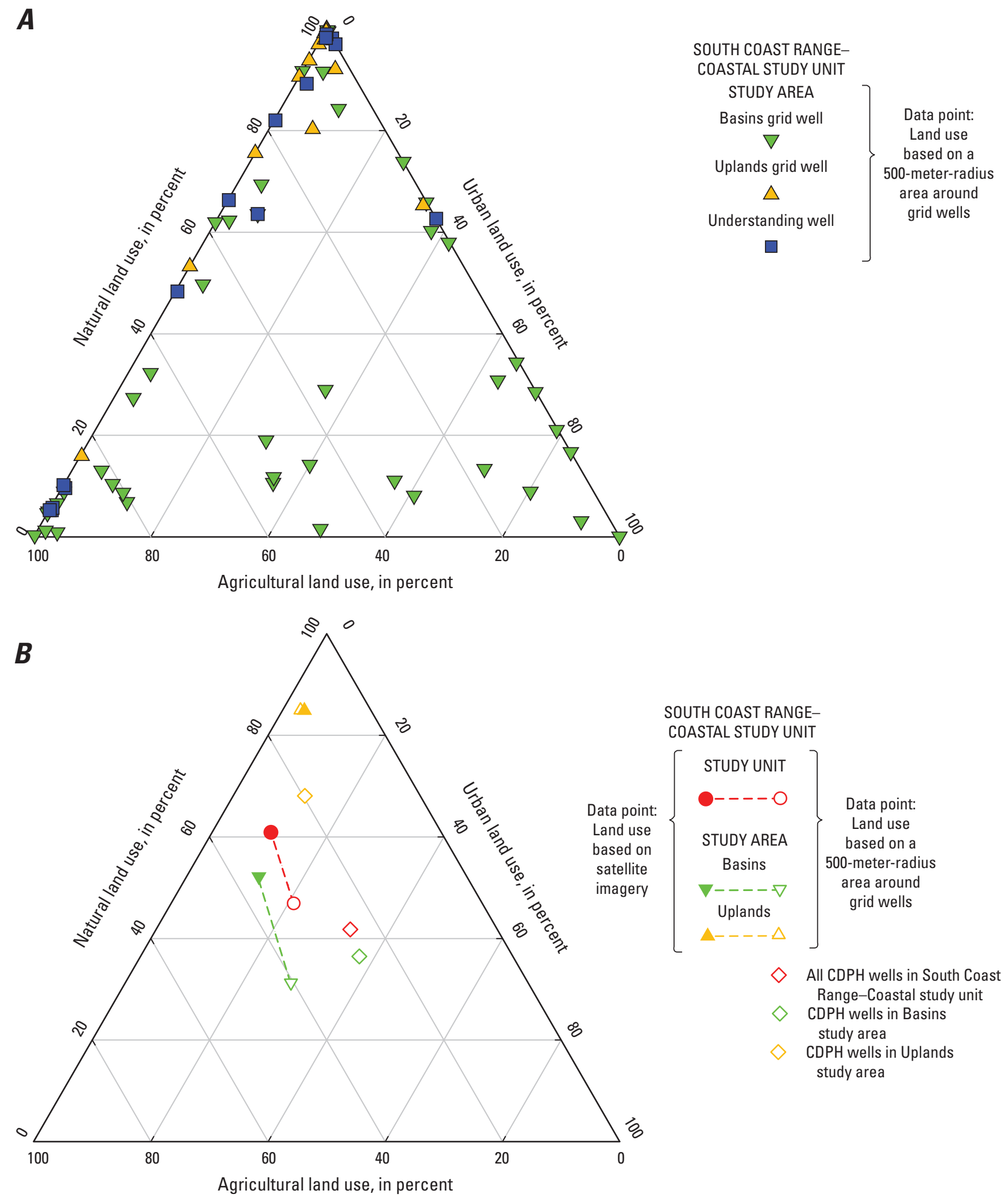

Figure 6. Ternary diagram with proportions of natural, agricultural, and urban land use for $(A)$ wells and $(B)$ the study unit and study areas, South Coast Range-Coastal study unit, California GAMA Priority Basin Project. 


\section{Depth}

The median well depth for grid wells in the SCRC study unit was $460 \mathrm{ft}$ (140 m) bls; well depths ranged from 68 to 1,263 ft bls (21-385 m bls; fig. 7A, table A1). The median depth to top-of-perforations for grid wells was $207 \mathrm{ft}$ (63 $\mathrm{m}$ ) bls. The median well depth for the Basins study area grid wells was $418 \mathrm{ft}(127 \mathrm{~m})$ bls; well depths ranged from 68 to $1,120 \mathrm{ft}$ bls (21-341 m bls; $\underline{\text { fig. } 7 \mathrm{~B}}$ ). The median well depth for Uplands study area grid wells was $575 \mathrm{ft}(175 \mathrm{~m})$ bls; well depths ranged from 260 to 1,263 ft (79-385 m) bls. The median depth to the top-of-perforations for the Basins study area grid wells was $188 \mathrm{ft}(57 \mathrm{~m})$ bls; depth to the top-ofperforations ranged from 33 to $650 \mathrm{ft}$ bls $(10-198 \mathrm{~m}$ bls; fig. 7B). The median depth to the top-of-perforations for Uplands study area grid wells was $252 \mathrm{ft}(77 \mathrm{~m})$ bls; depth to the top-of-perforations ranged from 75 to $535 \mathrm{ft}$ (23-163 m) bls. (fig. 7B). These values represent a subset of the grid wells because well depth and depth to the top-of-perforations were not known for several wells.

The median depth of USGS-understanding wells (130 ft [40 m] bls) in the SCRC study unit was shallower than the median depth for grid wells (ig. 7A). This was expected because 6 of the 15 understanding wells were monitoring wells that tap shallow groundwater. The median depth to top-of-perforations for USGS-understanding wells was $53 \mathrm{ft}$ (16 m) bls.

\section{Septic-System Density}

The number of septic tanks or cesspools in the 500-m (1,640-ft) radius around each USGS-grid and understanding well in the SCRC study unit ranged from 0 to 799 septic tanks per square kilometer (tanks $\left./ \mathrm{km}^{2}\right)$, with a median of 1.1 septic $\operatorname{tank} / \mathrm{km}^{2}$ (table D1). The number of septic tanks or cesspools ranged from 0 to 799 septic tanks $/ \mathrm{km}^{2}$ in the Basins study area and ranged from 0 to 9.4 septic tanks $/ \mathrm{km}^{2}$ in the Uplands study area (table D1).

\section{Formerly Leaking Underground Fuel Tanks}

The density of LUFTs located within the Thiessen polygon (a description of a Thiessen polygon can be found in appendix D in the section Formerly Leaking Underground Fuel Tanks) around each USGS- and CDPH-grid and USGSunderstanding well in the SCRC study unit ranged from $<0.01$ to 13.04 tanks $/ \mathrm{km}^{2}$, with a median of $0.02 \mathrm{tank} / \mathrm{km}^{2}$ (table D1). The median distance to the nearest LUFT was 9,012 ft $(2,747 \mathrm{~m})$. The LUFT density for most of the wells in the SCRC study unit was very low-usually less than $0.05 \operatorname{tank} / \mathrm{km}^{2}$
The density of LUFTs around grid and understanding wells in the Basins study area also ranged from $<0.01$ to 13.04 tanks $/ \mathrm{km}^{2}$, with a median of $0.02 \mathrm{tank} / \mathrm{km}^{2}$ (table D1). However, the median distance to the nearest LUFT was only $6,263 \mathrm{ft}(1,909 \mathrm{~m})$.

The density of LUFTs around grid and understanding wells was less in the Uplands study area $(<0.01$ to $0.37 \operatorname{tank} / \mathrm{km}^{2}$ ) than in the Basins study area, with a median of $0.01 \mathrm{tank} / \mathrm{km}^{2}$ (table D1). The median distance to the nearest LUFT in the Uplands study area was 18,441 ft (5,621 m).

\section{Groundwater Age}

Groundwater samples were assigned age classifications based on the tritium, carbon-14 $\left({ }^{14} \mathrm{C}\right)$, and terrigenic helium content of the samples (appendix D). Of the 70 USGS-grid and understanding wells in the SCRC study unit evaluated by the Priority Basin Project for groundwater age, groundwater samples were classified as modern for 21 wells, mixedage for 4 wells (evidence of both modern and pre-modern groundwater in the same sample), and pre-modern for 28 wells (table D2). Samples from nine wells were classified as pre-modern or mixed. For statistical purposes, these samples were combined with samples of pre-modern age. Samples from eight wells were classified as modern or mixedage because the age-tracer data were incomplete. For statistical purposes, these samples were combined with samples of mixed-age. Groundwater age varied between the two study areas (fig. 8A). Samples from all but one well in the Uplands study area were classified as pre-modern groundwater, whereas the wells in the Basins study area included a mixture of modern, mixed-age, and pre-modern groundwater.

\section{Geochemical Conditions}

Geochemical conditions investigated as potential explanatory factors in this report include oxidation-reduction characteristics, including dissolved oxygen (DO), and $\mathrm{pH}$. An abridged classification of oxidation-reduction (redox) conditions adapted from the framework presented by McMahon and Chapelle (2008) for USGS-grid and USGSunderstanding wells in the SCRC study unit is given in appendix D (table D3). The classification "indeterminate" was added to the framework for groundwater samples that did not have sufficient data available to be classified as oxic, anoxic/ suboxic, or mixed anoxic/oxic (Jurgens and others, 2009). $\mathrm{pH}$ data were available for all grid and understanding wells, but DO concentration data were not available for some grid wells. Groundwater in the SCRC study unit was oxic (redox category oxic, or DO greater than or equal to 0.5 milligram per liter [mg/L]) in 84 percent of USGS-grid wells and 79 percent of USGS-understanding wells. pH ranged from 5.8 to 7.9 in USGS-grid and understanding wells. 

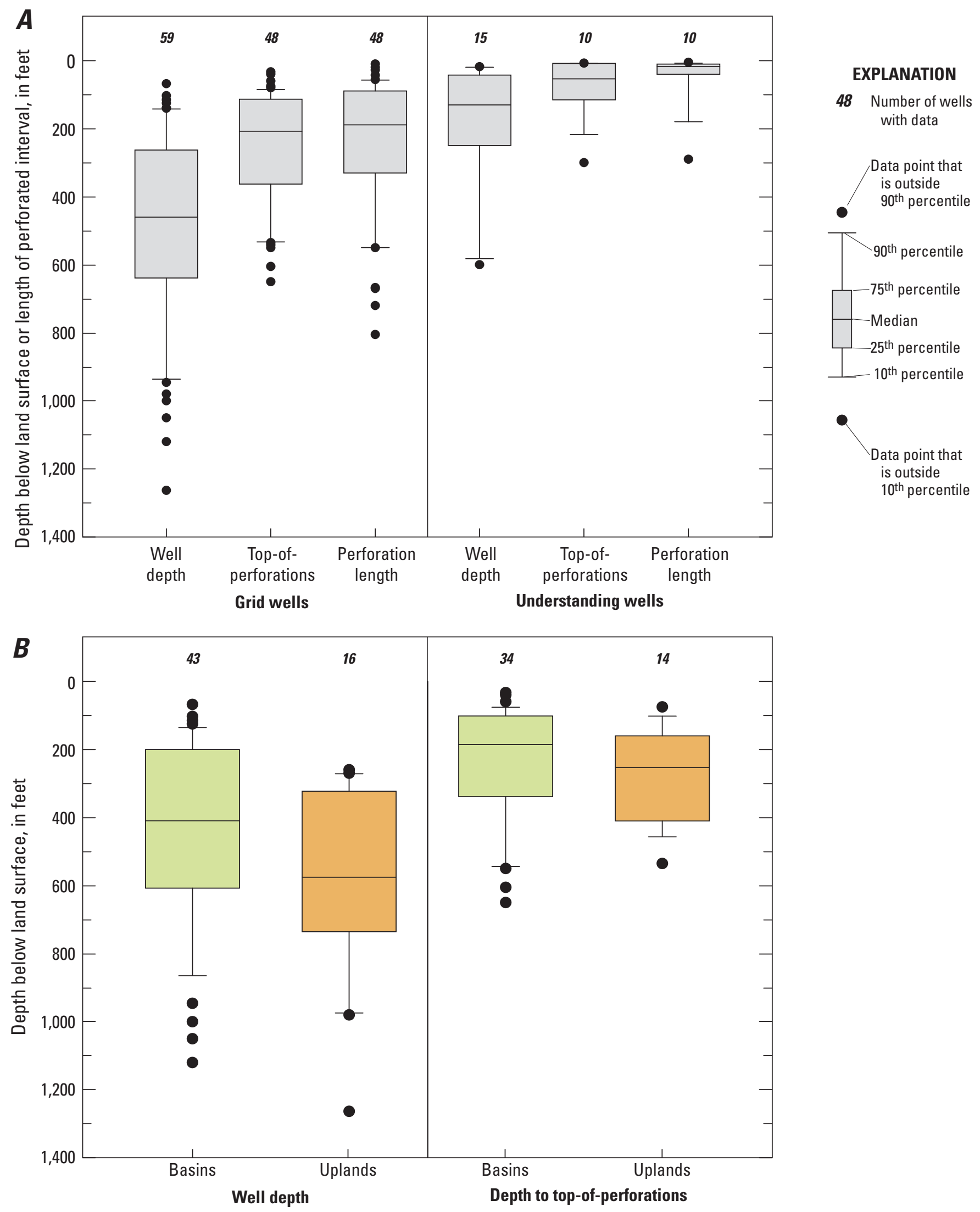

Figure 7. Construction characteristics for $(A)$ USGS- and CDPH-grid wells and USGS-understanding wells and $(B)$ grid wells in the Basins and Uplands study areas, South Coast Range-Coastal study unit, California GAMA Priority Basin Project. 
$\boldsymbol{A}$

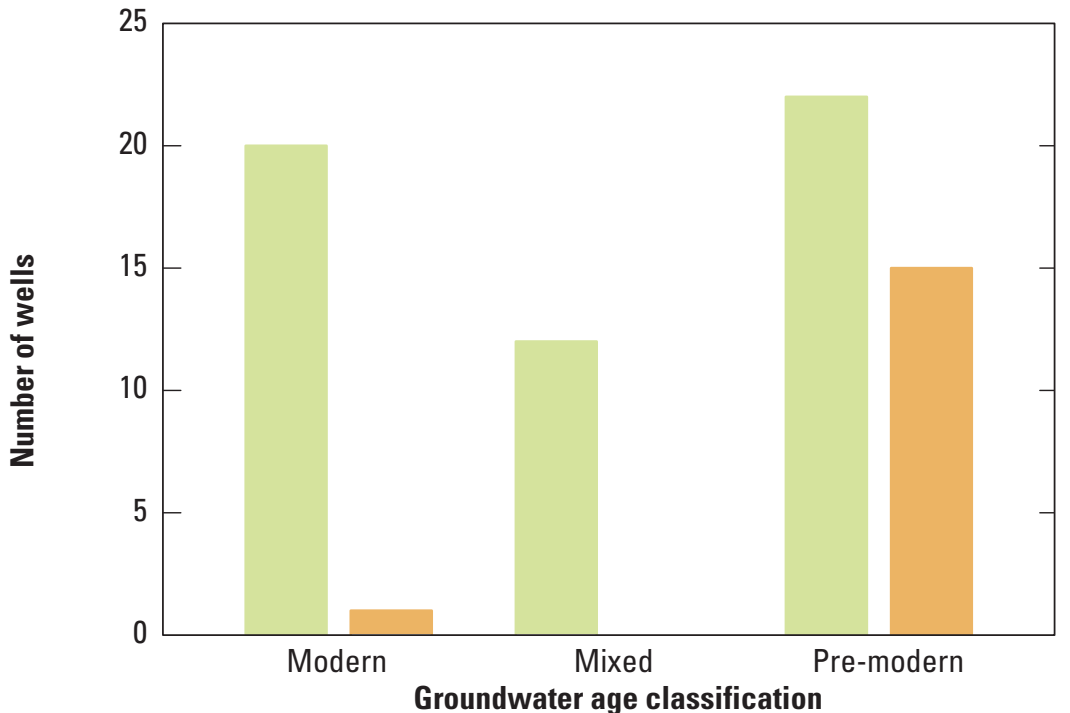

\section{EXPLANATION}

Basins study area

Uplands study area

$\boldsymbol{B}$

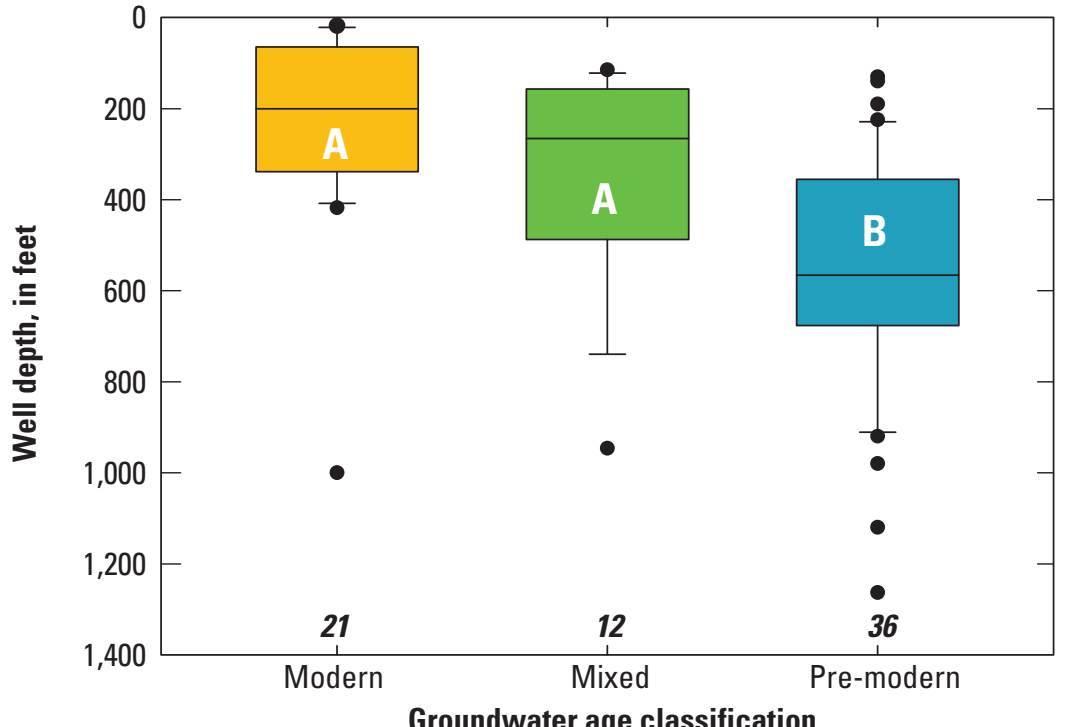

C

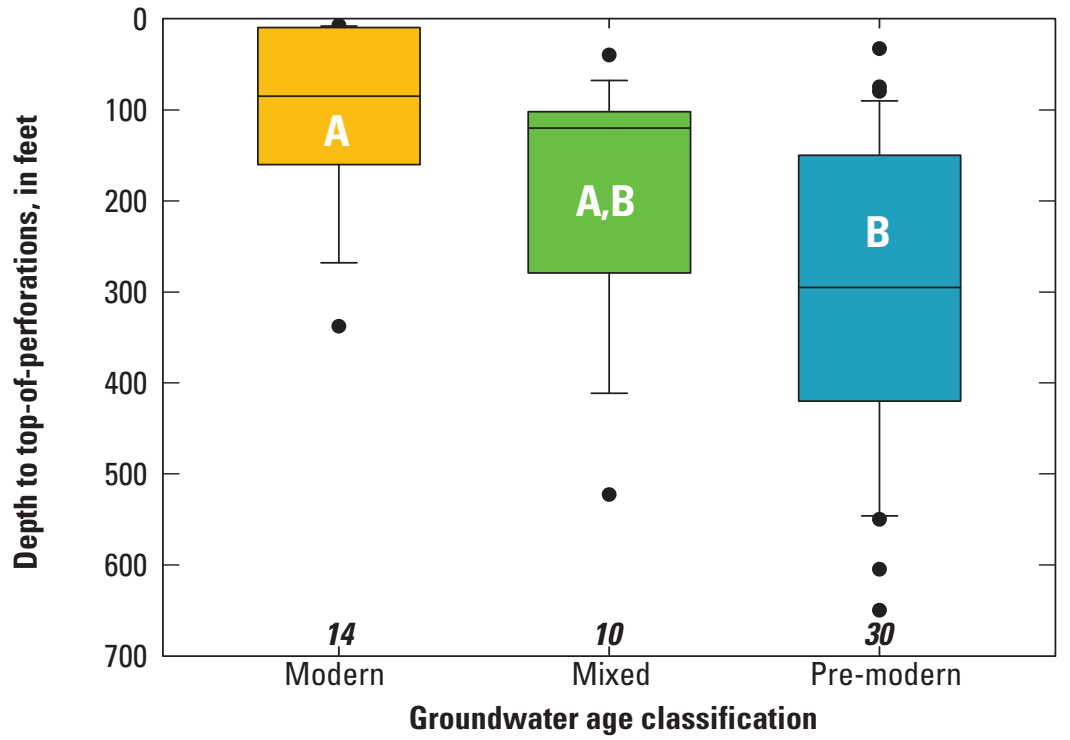

Boxes with different letters are significantly different

Figure 8. Groundwater age classification in relation to $(A)$ study areas, $(B)$ well depth, and $(C)$ depth to top-of-perforations, South Coast Range-Coastal study unit, California GAMA Priority Basin Project. 


\section{Correlations Between Explanatory Variables}

Apparent correlations between an explanatory variable and a water-quality constituent could indicate relations between two explanatory variables and not between an explanatory variable and a water-quality constituent. Therefore, significant correlations between explanatory variables are important to identify. Significant correlations between categorical explanatory variables that were obtained by using the Wilcoxon or Kruskal-Wallis statistical tests are given in table 5 for the SCRC study unit. Significant correlations between continuous explanatory variables that were obtained by using the Spearman's method are given in table 6.

Relations were observed between well depth and groundwater age. The median depth of USGS-grid and understanding wells in the SCRC study unit with groundwater classified as pre-modern was deeper than the depths of wells with groundwater classified as modern or mixed ages (table 5; fig. $8 B$ ). The median depth to the top-of-perforations of wells with groundwater classified as pre-modern also was deeper than the depth to the top-of-perforations of wells with groundwater classified as modern or mixed ages (table 5; fig. 8C). Well depths or depths to top-of-perforations in wells with groundwater samples classified as modern and mixed ages were not significantly different.

Groundwater ages for most SCRC wells perforated entirely at depths less than $400 \mathrm{ft}$ (122 m) bls (26 of 37 wells, 70 percent) were modern, mixed, or modern or mixed (fig. 9). Groundwater ages for most of the wells with the top-of-perforations less than $400 \mathrm{ft}$ but with the bottom-ofperforations greater than or equal to $400 \mathrm{ft}$ were pre-modern, or mixed or pre-modern (13 of 19 wells). Groundwater ages for wells perforated entirely at depths greater than or equal to $400 \mathrm{ft}$ were all pre-modern except for one well that had mixedage groundwater.

Each of the three depth categories included wells from more than one of the groundwater age classifications (fig. 9). The presence of pre-modern groundwater from wells less than $400 \mathrm{ft}$ (122 m) deep and mixed-age groundwater from wells greater than or equal to $400 \mathrm{ft}$ deep (fig. 9) indicates that there are local variations in the general groundwater age-depth relations. These variations may indicate the position of the well relative to the regional groundwater flow system.

Wells with pre-modern groundwater were more likely to be in areas of natural land use than wells with modern groundwater (table 5). Urban and natural land uses were correlated with LUFTs. The density of LUFTs increased as the percentage of urban land use increased; in contrast, the LUFT density decreased as the percentage of natural land use increased (table 6). The distance to the nearest LUFT was less for wells in urban land-use areas than for wells in natural landuse areas (tables 5 and $\underline{6}$ ).

DO concentrations were greater for modern groundwater than for pre-modern groundwater and were positively correlated with agricultural land use, $\mathrm{pH}$, and the number of

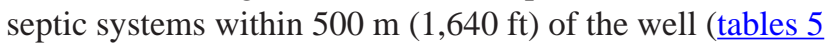
and $\underline{6}$ ). The lack of a correlation between DO and well depth was unexpected because DO concentrations were lower in pre-modern and mixed-age groundwater, and groundwater age

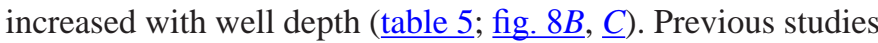
in other aquifers have reported a negative correlation of DO with depth (McMahon and Chapelle, 2008; Burton and others, 2011); however, some other Priority Basin Project study units located in coastal basins also did not have a correlation of DO with depth (Kulongoski and others, 2010; Kulongoski and Belitz, 2011). DO was correlated with agricultural land use. This correlation was not found in other Priority Basin Project study units (Kulongoski and Belitz, 2010; Landon and others, 2010; Burton and others, 2011, 2012). The correlation of DO with agriculture may be a result of irrigation practices which may accelerate the percolation of aerated water to the primary aquifer system. DO also was positively correlated with $\mathrm{pH}$. This correlation was different from findings for other study units in the GAMA Priority Basin Project that reported DO to be negatively correlated or not correlated to $\mathrm{pH}$ (Kulongoski and others, 2010; Landon and others, 2010; Kulongoski and Belitz, 2011; Burton and others, 2012; Fram and Belitz, 2012). Areas with low DO include parts of the Santa Ynez River Valley and San Antonio Creek Valley groundwater basins and the northern edge of the Santa Maria River Valley groundwater basin (fig. 10A).

$\mathrm{pH}$ was positively correlated with the depth to top-ofperforations and the density of septic systems within $500 \mathrm{~m}$ $(1,640 \mathrm{ft})$ of the well. Wells with groundwater having a $\mathrm{pH}$ of less than 7 are located in the area near Arroyo Grande, as well as near the San Antonio Creek Valley and the Santa Ynez River Valley groundwater basins (fig. 10B). Wells with groundwater having a $\mathrm{pH}$ greater than 7.5 primarily are located south of the city of Santa Maria and in the eastern portion of the Santa Ynez River Valley groundwater basin. 
Table 5. Results of nonparametric statistical tests (Kruskal-Wallis or Wilcoxon) for differences in values of potential categorical and continuous explanatory factors and differences in values of potential categorical explanatory factors and selected water-quality constituents for the South Coast Range-Coastal study unit, California GAMA Priority Basin Project.

[Groundwater age class: Mod, modern water; Mix, mixture of modern and pre-modern water; preM, pre-modern water (see appendix D for explanation of groundwater age classes). p-values less than 0.05 calculated using the Kruskal-Wallis (for comparing three or more groups) or Wilcoxon (for comparing two groups). Nonparametric tests indicate significant differences. Abbreviations GAMA, Groundwater Ambient Monitoring and Assessment Program; Ag, agricultural; Nat, natural; m, meter; mg/L, milligrams per liter; na, not applicable; ns, not significant; VOC, volatile organic compound; >, greater than; $<$, less than; tanks $/ \mathrm{km}^{2}$, tanks per square kilometer]

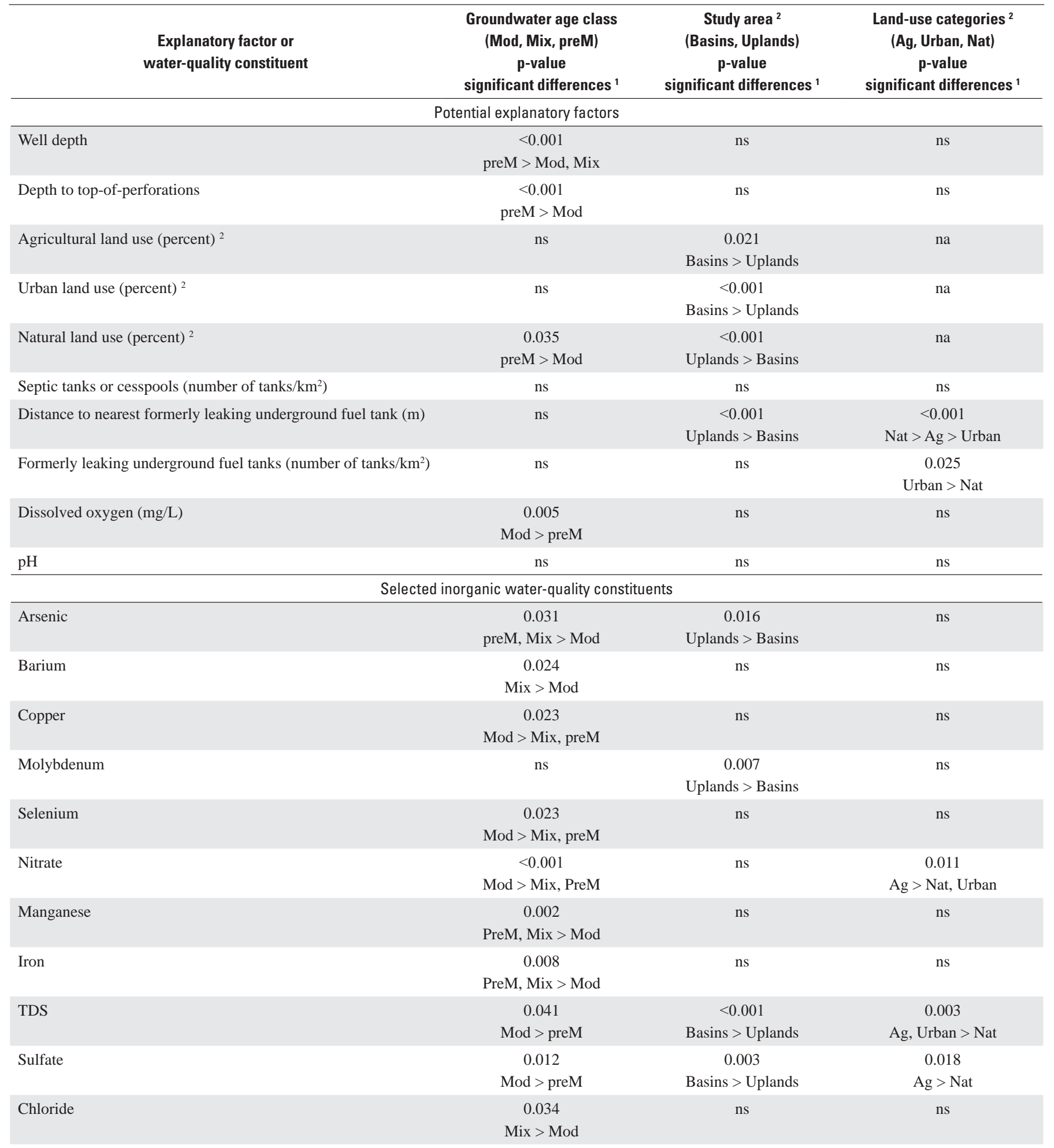


Table 5. Results of nonparametric statistical tests (Kruskal-Wallis or Wilcoxon) for differences in values of potential categorical and continuous explanatory factors and differences in values of potential categorical explanatory factors and selected water-quality constituents for the South Coast Range-Coastal study unit, California GAMA Priority Basin Project.-Continued

[Groundwater age class: Mod, modern water; Mix, mixture of modern and pre-modern water; preM, pre-modern water (see appendix D for explanation of groundwater age classes). p-values less than 0.05 calculated using the Kruskal-Wallis (for comparing three or more groups) or Wilcoxon (for comparing two groups). Nonparametric tests indicate significant differences. Abbreviations GAMA, Groundwater Ambient Monitoring and Assessment Program; Ag, agricultural; Nat, natural; m, meter; mg/L, milligrams per liter; na, not applicable; ns, not significant; VOC, volatile organic compound; >, greater than; $<$, less than; tanks $/ \mathrm{km}^{2}$, tanks per square kilometer]

\begin{tabular}{|c|c|c|c|}
\hline Potential explanatory factors & $\begin{array}{l}\text { Groundwater age class } \\
\text { (Mod, Mix, preM) } \\
\text { p-value } \\
\text { significant differences }{ }^{1}\end{array}$ & $\begin{array}{c}\text { Study area } \\
\text { (Basins, Uplands) } \\
\text { p-value } \\
\text { significant differences }{ }^{1}\end{array}$ & $\begin{array}{c}\text { Land-use categories }^{2} \\
\text { (Ag, Urban, Nat) } \\
\text { p-value } \\
\text { significant differences }{ }^{1}\end{array}$ \\
\hline \multicolumn{4}{|c|}{ Selected organic and special-interest water-quality constituents } \\
\hline Number of VOC detections ${ }^{3}$ & ns & ns & ns \\
\hline Chloroform & ns & ns & ns \\
\hline Number of solvent detections & $\begin{array}{c}0.027 \\
\text { Mod }>\text { PreM }\end{array}$ & ns & ns \\
\hline Perchloroethene (PCE) & $\begin{array}{c}0.016 \\
\text { Mod > preM }\end{array}$ & ns & ns \\
\hline Number of other VOC detections & ns & ns & ns \\
\hline Dichlorodifluoromethane (CFC-12) & $\begin{array}{c}0.038 \\
\text { Mod > preM }\end{array}$ & ns & ns \\
\hline Number of pesticide detections ${ }^{4}$ & $\begin{array}{c}0.035 \\
\text { Mod > preM }\end{array}$ & ns & ns \\
\hline Perchlorate & ns & $\begin{array}{c}0.037 \\
\text { Basins }>\text { Uplands }\end{array}$ & $\begin{array}{c}0.027 \\
\text { Ag }>\text { Urban }\end{array}$ \\
\hline
\end{tabular}

${ }^{1}$ Only significant differences are shown. For example, PreM>Mod for well depth means that wells with pre-modern-age water are significantly deeper than wells with modern-age water, but wells with mixed-age water are not significantly different from wells with pre-modern-age or modern-age water.

${ }^{2}$ Grid wells only.

${ }^{3}$ Does not include VOCs classified as fumigants.

${ }^{4}$ Includes VOCs classified as fumigants. 
Table 6. Results of nonparametric (Spearman's method) analysis of correlations between selected potential explanatory factors in grid and understanding wells, South Coast Range-Coastal study unit, California GAMA Priority Basin Project.

[Spearman's correlation statistic $(\rho)$ and p-values are shown when correlations between selected potential explanatory factors are significant $(p<0.05)$. Number of septic tanks or cesspools in 500-meter radius around each well (U.S. Census Bureau, 1990). Number of formerly leaking underground fuel tanks within a Thiessen polygon, in square kilometers, data from Geographic Information Management System GeoTracker (California Environmental Protection Agency, 2001). Abbreviations GAMA, Groundwater Ambient Monitoring and Assessment Program; p, significance level of Spearman's test based on a threshold value $(\alpha)$ of $0.05 ; \mathrm{LSD}$, land surface datum; $\mathrm{m}$, meter; $\mathrm{mg} / \mathrm{L}$, milligrams per liter; $\mathrm{ns}$, not significant; tanks $/ \mathrm{km}^{2}$, tanks per square kilometer]

\begin{tabular}{|c|c|c|c|c|c|c|c|}
\hline \multirow[b]{2}{*}{$\begin{array}{l}\text { Explanatory } \\
\text { factor }\end{array}$} & \multicolumn{7}{|c|}{$\rho / p$} \\
\hline & $\begin{array}{c}\text { Well depth } \\
\text { (in feet below } \\
\text { LSD) }\end{array}$ & $\begin{array}{c}\text { Depth to } \\
\text { top-of- } \\
\text { perforations } \\
\text { (in feet below } \\
\text { LSD) }\end{array}$ & $\begin{array}{c}\text { Dissolved } \\
\text { oxygen } \\
\text { (mg/L) }\end{array}$ & $\mathrm{pH}$ & $\begin{array}{c}\text { Number of } \\
\text { septic tanks } \\
\text { (number of } \\
\text { tanks/km²) }\end{array}$ & $\begin{array}{l}\text { Distance } \\
\text { to nearest } \\
\text { formerly } \\
\text { leaking } \\
\text { underground } \\
\text { fuel tank } \\
\text { (m) }\end{array}$ & $\begin{array}{l}\text { Number of } \\
\text { formerly } \\
\text { leaking } \\
\text { underground } \\
\text { fuel tanks } \\
\text { (number of } \\
\text { tanks/km²) }\end{array}$ \\
\hline \multicolumn{8}{|c|}{ Grid wells used in analysis } \\
\hline Agricultural land use (percent) & ns & ns & $\begin{array}{l}0.284 \\
0.022\end{array}$ & ns & ns & ns & ns \\
\hline Natural land use (percent) & ns & ns & ns & ns & $\begin{array}{r}-0.249 \\
0.033\end{array}$ & $\begin{array}{r}0.523 \\
<0.001\end{array}$ & $\begin{array}{r}-0.419 \\
0.008\end{array}$ \\
\hline Urban land use (percent) & ns & ns & ns & ns & $\begin{array}{l}0.330 \\
0.004\end{array}$ & $\begin{array}{l}-0.696 \\
<0.001\end{array}$ & $\begin{array}{r}0.395 \\
<0.001\end{array}$ \\
\hline $\begin{array}{l}\text { Depth to top-of-perforations } \\
\text { (in feet below LSD) }\end{array}$ & & & ns & $\begin{array}{l}0.273 \\
0.042\end{array}$ & ns & ns & ns \\
\hline Dissolved oxygen (mg/L) & & & & $\begin{array}{l}0.281 \\
0.023\end{array}$ & $\begin{array}{l}0.305 \\
0.014\end{array}$ & ns & ns \\
\hline $\mathrm{pH}$ & & & & & $\begin{array}{l}0.243 \\
0.040\end{array}$ & ns & ns \\
\hline $\begin{array}{l}\text { Number of septic tanks or cesspools } \\
\text { (number of tanks } / \mathrm{km}^{2} \text { ) }\end{array}$ & & & & & & $\begin{array}{r}-0.294 \\
0.014\end{array}$ & ns \\
\hline $\begin{array}{l}\text { Distance to nearest formerly leaking } \\
\text { underground fuel tank (m) }\end{array}$ & & & & & & & $\begin{array}{l}-0.557 \\
<0.001\end{array}$ \\
\hline
\end{tabular}




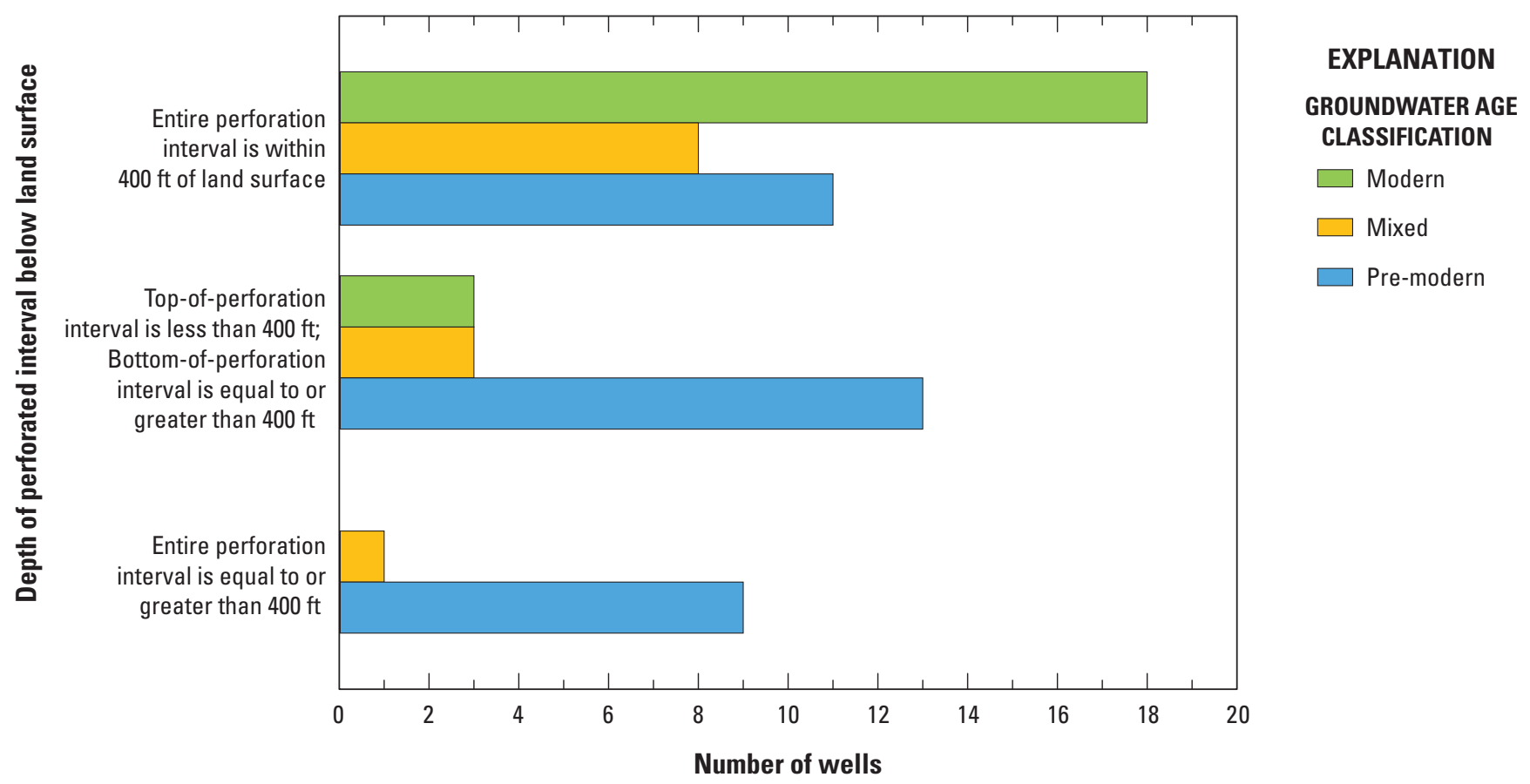

Figure 9. Relation of groundwater age classification to numbers of wells in each of the three depth categories, South Coast Range-Coastal study unit, California GAMA Priority Basin Project.

\section{Status and Understanding of Water Quality}

The status assessment was designed to identify the constituents or classes of constituents most likely to be water-quality concerns because of high relativeconcentrations or prevalence. The assessment applies only to constituents with regulatory (MCL-US, MCL-CA, and AL-US) or non-regulatory (HAL-US, RSD5-US, or NL-CA) human-health benchmarks or aesthetic benchmarks (SMCL-US or SMCL-CA) established by the USEPA or the CDPH (California Department of Public Health, 2008a; U.S. Environmental Protection Agency, 2008a, b). The spatially distributed, randomized approach to well selection and data analysis yields a view of groundwater quality in which all areas of the primary aquifer system are weighted equally.

The understanding assessment was designed to help answer the question of why specific constituents are, or are not, detected in groundwater. The understanding assessment addresses a subset of the constituents discussed in the status assessment and is based on statistical correlations between water quality and a selected set of potential explanatory factors. This assessment may improve our understanding of how human and natural sources of contaminants affect groundwater quality in the SCRC study unit; however, it was not designed to identify specific sources of constituents to specific wells.

Samples from USGS-grid wells in the SCRC study unit were analyzed for 205 organic constituents (85 VOCs, 63 pesticides, and 57 polar pesticides) and 2 special-interest constituents. In USGS-grid wells, about one-tenth of organic and special-interest constituents analyzed for were detected (22 of 207). Human-health benchmarks are established for about two-thirds of the organic and special-interest constituents detected (14 of 22, table 7). Of the 85 VOCs analyzed, 9 VOCs were detected - 8 with human-health benchmarks. Of the 120 pesticides and polar pesticides analyzed, 8 pesticides and 4 pesticide degradates were detected (Mathany and others, 2010). Five of the eight pesticides had human-health benchmarks (Mathany and others, 2010). The four pesticide degradates [de-ethylatrazine, 3,4-dichloroanaline, 3-(4-chlorophenyl)-1-methyl urea, and fipronil sulfide] did not have benchmarks; however, humanhealth benchmarks are established for two of the three parent compounds (atrazine and diuron) of these degradates. Humanhealth benchmarks have not been established for the parent compound (fipronil) of the remaining two degradates that were detected. Human-health benchmarks are established for the constituent of special interest detected (perchlorate). Thus, most of the organic and special-interest compounds detected in groundwater in the SCRC study unit have established benchmarks. 


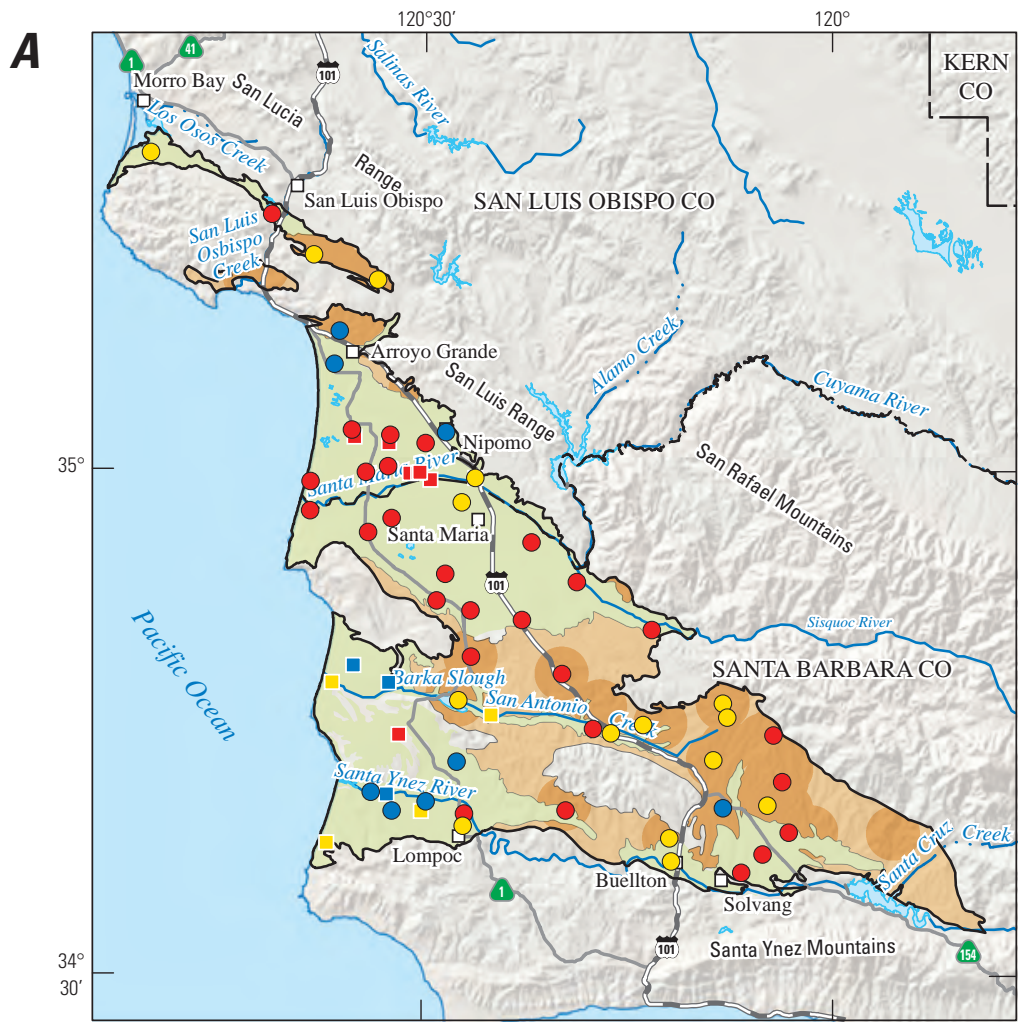

\section{EXPLANATION}

$\begin{array}{ll}\text { Study unit boundary } & \text { Study areas } \\ \square & \text { Uplands/Grid }\end{array}$

Dissolved oxygen concentration, in milligrams per liter

Grid wells

$0<0.5$

0.5 to $<2$

$0 \geq 2$

Understanding wells

- $<0.5$

a. 0.5 to $<2$

- $\geq 2$
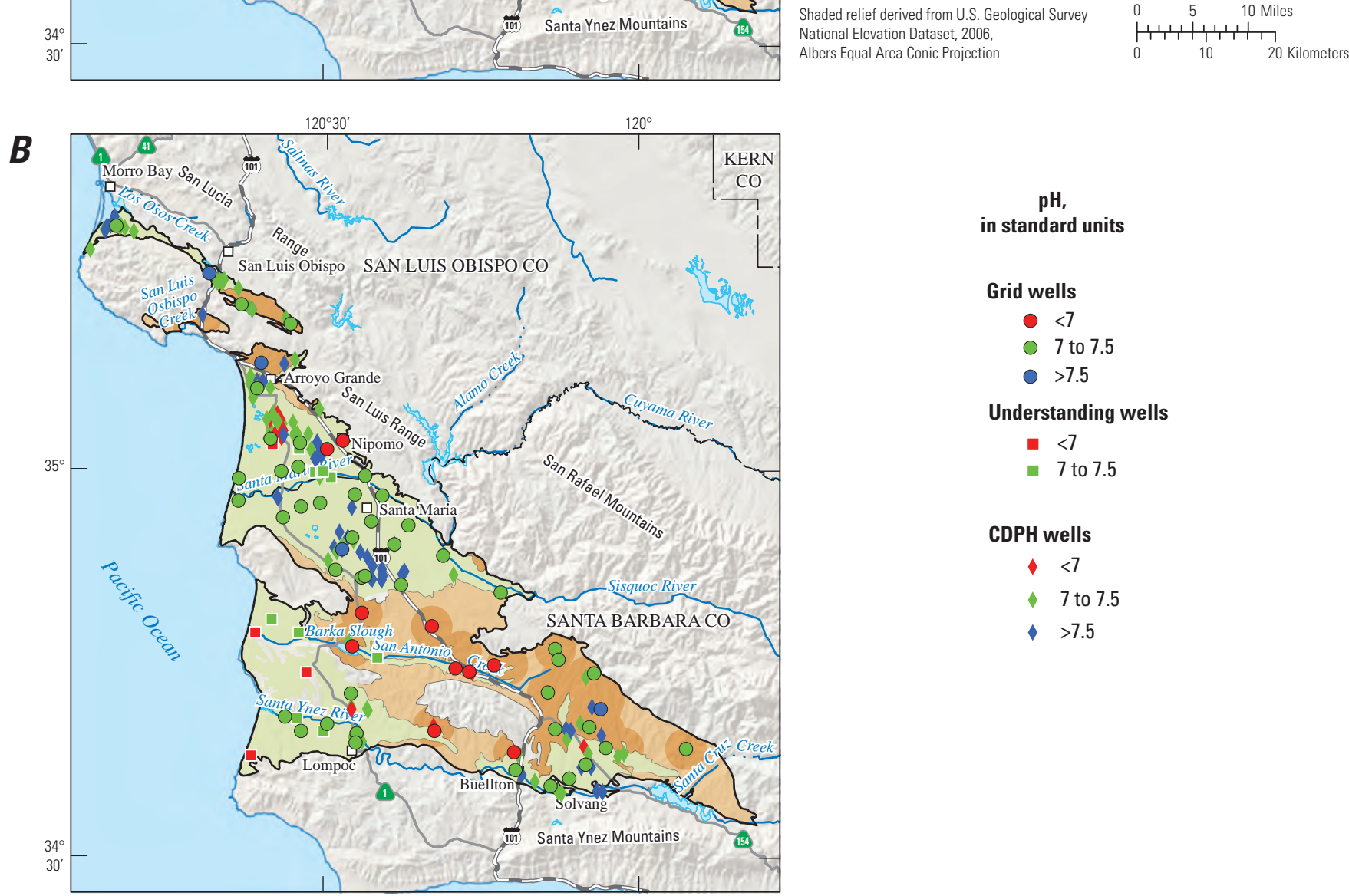

$\mathrm{pH}_{\text {, }}$

in standard units

Grid wells

- $<7$

○ 7 to 7.5

- $>7.5$

Understanding wells

- $<7$

ㅁ 7 to 7.5

CDPH wells

$-<7$

7 to 7.5

$>7.5$

Figure 10. $(A)$ Dissolved oxygen concentrations and $(B) \mathrm{pH}$ values for wells in the South Coast Range-Coastal study unit, California GAMA Priority Basin Project. 
Table 7. Number of constituents analyzed and detected in USGS-grid wells, listed by human-health-based or aesthetic benchmarks and constituent class, in the South Coast RangeCoastal study unit, California GAMA Priority Basin Project.

[Regulatory human-health benchmarks include U.S. Environmental Protection Agency (USEPA) maximum contaminant level and California Department of Public Health (CDPH) maximum contaminant level. Non-regulatory humanhealth benchmarks include USEPA lifetime health advisory levels and riskspecific dose level at $10^{-5}$ lifetime cancer risk and CDPH notification level. Abbreviations GAMA, Groundwater Ambient Monitoring and Assessment Program; HHB, human-health-based benchmark; NWQL, U.S. Geological Survey (USGS) National Water Quality Laboratory; SMCL, USEPA or CDPH secondary maximum contaminant level (aesthetic based)]

\begin{tabular}{|c|c|c|}
\hline Benchmark type & $\begin{array}{c}\text { Number of } \\
\text { constituents } \\
\text { analyzed }\end{array}$ & $\begin{array}{l}\text { Number of } \\
\text { constituents } \\
\text { detected }\end{array}$ \\
\hline \multicolumn{3}{|c|}{ Volatile organic compounds (VOCs) } \\
\hline Regulatory HHB & 33 & 17 \\
\hline Non-regulatory HHB & 25 & 1 \\
\hline None & 27 & 1 \\
\hline Total & 85 & 9 \\
\hline \multicolumn{3}{|c|}{ Pesticides and degradates } \\
\hline Regulatory HHB & 3 & 2 \\
\hline Non-regulatory HHB & 17 & ${ }^{1} 1$ \\
\hline None & 43 & 6 \\
\hline Total & 63 & 9 \\
\hline \multicolumn{3}{|c|}{ Polar pesticides and degradates } \\
\hline Regulatory HHB & 8 & 0 \\
\hline Non-regulatory HHB & 11 & 2 \\
\hline None & 38 & ${ }^{1} 1$ \\
\hline Total & 57 & 3 \\
\hline \multicolumn{3}{|c|}{ Special-interest constituents } \\
\hline Regulatory HHB & 1 & 1 \\
\hline Non-regulatory HHB & 1 & 0 \\
\hline Total & 2 & 1 \\
\hline \multicolumn{3}{|c|}{ Inorganic and radioactive constituents } \\
\hline Regulatory HHB & 20 & 20 \\
\hline Non-regulatory HHB & 5 & 5 \\
\hline Aesthetic - SMCL & 7 & 7 \\
\hline None & 14 & 14 \\
\hline Total & 46 & 46 \\
\hline
\end{tabular}

${ }^{1}$ Additional constituent(s) were detected in USGS-understanding wells.
In contrast to organic constituents, all inorganic constituents analyzed for were detected (46 of 46 , table 7 ) in USGS- and CDPH-grid wells. Human-health or aesthetic benchmarks have been established for more than two-thirds of the inorganic constituents detected (32 of 46). Most of the 14 constituents without benchmarks are major or minor ions that are naturally present in nearly all groundwater.

The maximum relative-concentration for each constituent with a water-quality benchmark in grid wells is shown in figure 11. In the SCRC study unit, seven inorganic constituents were detected at high relative-concentrations in one or more grid wells, and eight additional inorganic constituents were detected at moderate relative-concentrations. In contrast, none of the organic and special-interest constituents were detected at high relative-concentrations in grid wells, although two constituents, one organic and one special-interest constituent, were detected at moderate relative-concentrations.

Aquifer-scale proportions were calculated for each inorganic and organic constituent detected at high or moderate relative-concentrations and for each organic and specialinterest constituent detected in more than 10 percent of the grid wells (table 8). The spatially weighted high aquifer-scale proportions for these constituents were within the 90 percent confidence intervals for their respective grid-based high aquifer-scale proportions, providing evidence that the gridbased approach yields statistically equivalent results to the spatially weighted approach.

\section{Inorganic Constituents}

Inorganic constituents generally occur naturally in groundwater, although concentrations of these constituents may be affected by human as well as natural factors. Inorganic constituents in the SCRC study unit with human-health benchmarks, as a class (trace elements and minor ions, radioactive constituents, and nutrients), were detected at high relative-concentrations in 33 percent, at moderate relative-concentrations in 35 percent, and at low relative-concentrations or not detected in 31 percent of the primary aquifer system (table 9). Inorganic constituents with aesthetic benchmarks, as a class, were detected at high relative-concentrations in 35 percent, at moderate relative-concentrations in 55 percent, and at low relativeconcentrations or not detected in 11 percent of the primary aquifer system. All detections are in untreated groundwater collected from the primary aquifer system and not from drinking water; generally, drinking water is treated before it is delivered to consumers by water purveyors. 


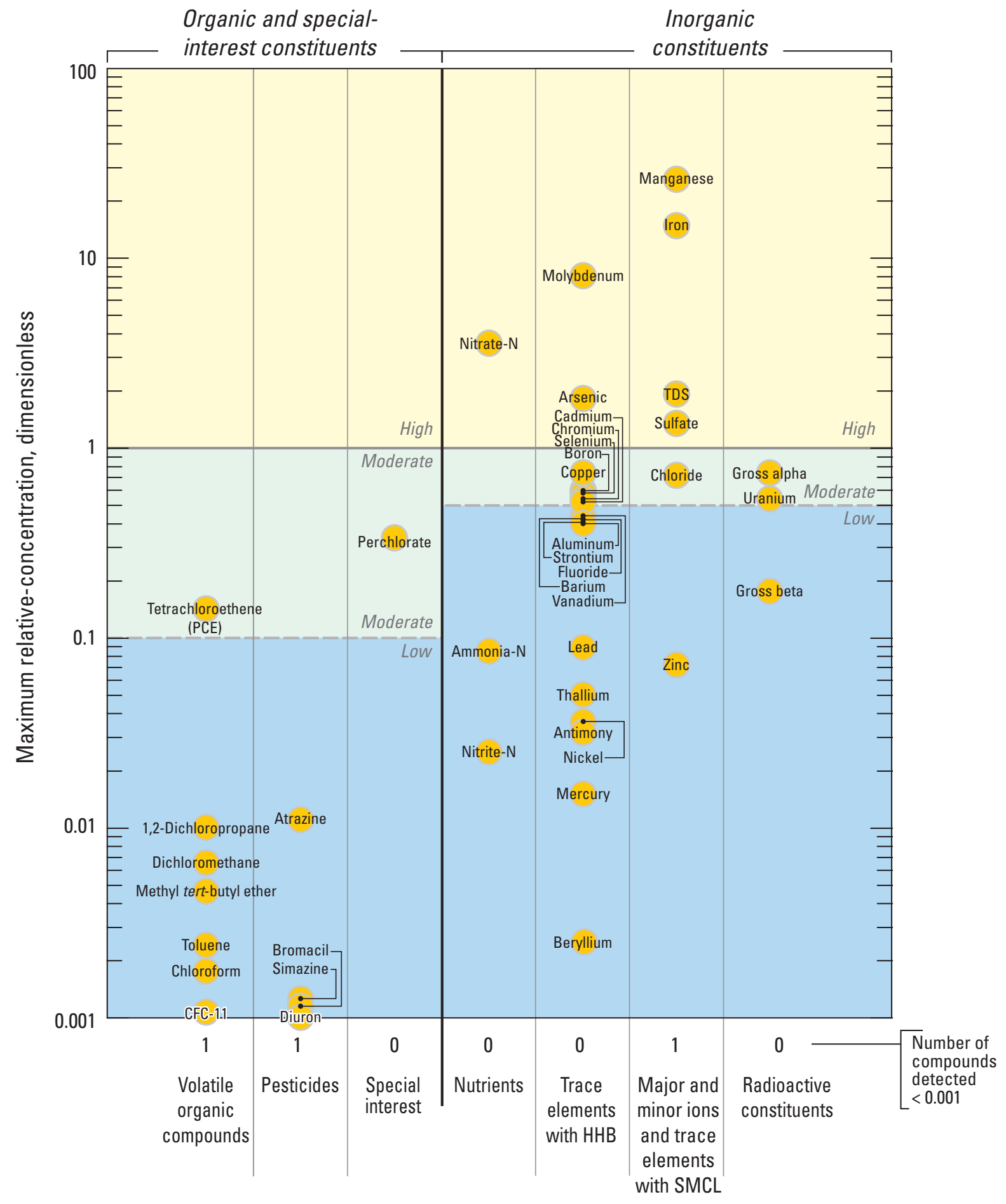

EXPLANATION

Silver Name and center of symbol is the maximum relative-concentration for that constituentUnless indicated by following location line:

Abbreviations: N, nitrogen; TDS, total dissolved solids; HHB, human-health-based benchmark; SMCL, secondary maximum contaminant levels

Figure 11. Maximum relative-concentration in USGS- and CDPH-grid wells for detected constituents by constituent class, South Coast Range-Coastal study unit, California GAMA Priority Basin Project. 


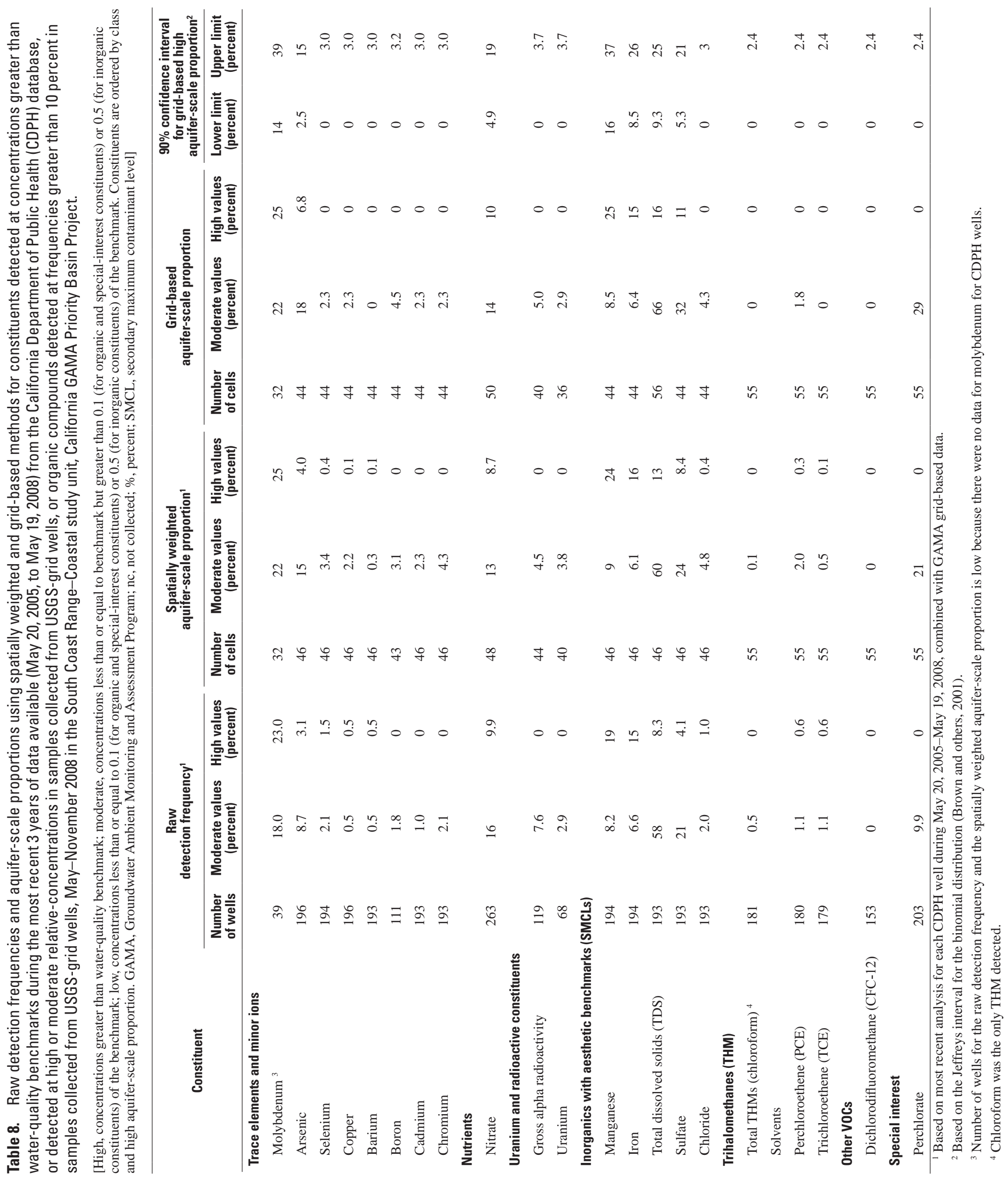


Table 9. Aquifer-scale proportions for constituent classes and constituents of special interest for the South Coast Range-Coastal study unit, California GAMA Priority Basin Project.

[Aquifer-scale proportions are given in percentage of area of the primary aquifer. All values greater than 10 percent are rounded to the nearest 1 percent. Values less than 10 percent are rounded to the nearest 0.1 percent. Values may not add up to 100 precent because of rounding. GAMA, Groundwater Ambient Monitoring and Assessment Program; VOCs, volatile organic compounds; SMCL, secondary maximum contaminant level; TDS, total dissolved solids; $\mathrm{SO}_{4}$, sulfate; $\mathrm{Cl}$, chloride]

\begin{tabular}{|c|c|c|c|}
\hline \multirow{2}{*}{ Constituent class } & \multicolumn{3}{|c|}{$\begin{array}{l}\text { Aquifer-scale proportion } \\
\text { (percent) }\end{array}$} \\
\hline & High & Moderate & $\begin{array}{c}\text { Low or } \\
\text { not detected }\end{array}$ \\
\hline \multicolumn{4}{|l|}{ Inorganics with human-health benchmarks } \\
\hline Trace elements and minor ions & 27 & 29 & 44 \\
\hline Uranium and radioactive constituents ${ }^{1}$ & 0 & 5.0 & 95 \\
\hline Nutrients & 10 & 14 & 76 \\
\hline $\begin{array}{l}\text { Any inorganic with human-health } \\
\text { benchmarks }\end{array}$ & 33 & 35 & 31 \\
\hline \multicolumn{4}{|c|}{ Inorganics with aesthetic benchmarks (SMCLs) } \\
\hline Major ions (TDS, $\mathrm{SO}_{4}, \mathrm{Cl}$ ) & 19 & 65 & 16 \\
\hline Manganese and iron & 34 & 4.3 & 62 \\
\hline Any inorganic with an SMCL & 35 & 55 & 11 \\
\hline \multicolumn{4}{|l|}{ Organics with human-health benchmarks } \\
\hline Trihalomethanes (chloroform)² & 0 & 0.1 & 100 \\
\hline Solvents & 0.4 & 1.8 & 98 \\
\hline Other VOCs & 0 & 0 & 100 \\
\hline Pesticides & 0 & 0 & 100 \\
\hline Any organic constituent & 0.4 & 1.8 & 98 \\
\hline \multicolumn{4}{|l|}{ Constituents of special interest } \\
\hline Perchlorate, NDMA & 0 & 29 & 71 \\
\hline
\end{tabular}

${ }^{1}$ Aquifer-scale proportions for the class uranium and radioactive constituents and all inorganic constituents with health-based benchmarks were calculated using unadjusted gross alpha activity.

${ }^{2}$ Chloroform was the only THM detected.

\section{Trace Elements and Minor lons}

In the SCRC study unit, trace elements, as a class, were detected at high relative-concentrations in 27 percent, at moderate relative-concentrations in 29 percent, and at low relative-concentrations or not detected in 44 percent of the primary aquifer system (table 9). The only trace elements with human-health benchmarks with high relative-concentrations in more than 2 percent of the primary aquifer system were arsenic and molybdenum (table 8). Barium, copper, and selenium were detected at high relative-concentrations in less than 2 percent of the primary aquifer system. Boron, cadmium, and chromium were detected at moderate concentrations (table 8; fig. 12). Only constituents detected at high relativeconcentrations in more than 2 percent of the primary aquifer system in the study unit are discussed further in this report.

\section{Arsenic}

Arsenic is a naturally occurring semi-metallic trace element. The most common source of arsenic is from aquifer materials, including dissolution of arsenic-rich minerals such as arsenopyrite, a common constituent of shales, and apatite, a common constituent of phosphorites. Arsenic in ocean waters is often sequestered by iron or manganese hydroxides in marine sediment (Maher, 1984) or can be incorporated into pyrite (Belzile and Lebel, 1986). Anthropogenic sources of arsenic include use as a wood preservative, in paints and dyes, in drugs, and in the mining of copper and gold (Welch and others, 2000).

Arsenic was detected at high relative-concentrations in 6.8 percent of the primary aquifer system in the SCRC study unit (table 8). Arsenic was detected at high relativeconcentrations in USGS- and CDPH-grid wells in the Basins and Uplands study areas (fig. 12). The grid well with high relative-concentrations of arsenic in the Basins study area was located in the Santa Ynez River Valley (fig. 13A). The two grid wells with high relative-concentrations of arsenic in the Uplands study area are located between the Santa Ynez River Valley and Santa Maria River Valley groundwater basins. There is one CDPH-other well with high relativeconcentration located just north of the Santa Maria River Valley (fig. 13A).

Arsenic concentrations were higher in pre-modern and mixed-age groundwater than in modern groundwater (table 5). Arsenic concentrations were not significantly correlated to any of the other explanatory variables investigated in the SCRC study unit (table 10), although arsenic concentrations were significantly higher in the Uplands study area (table 5). 
$\boldsymbol{A}$

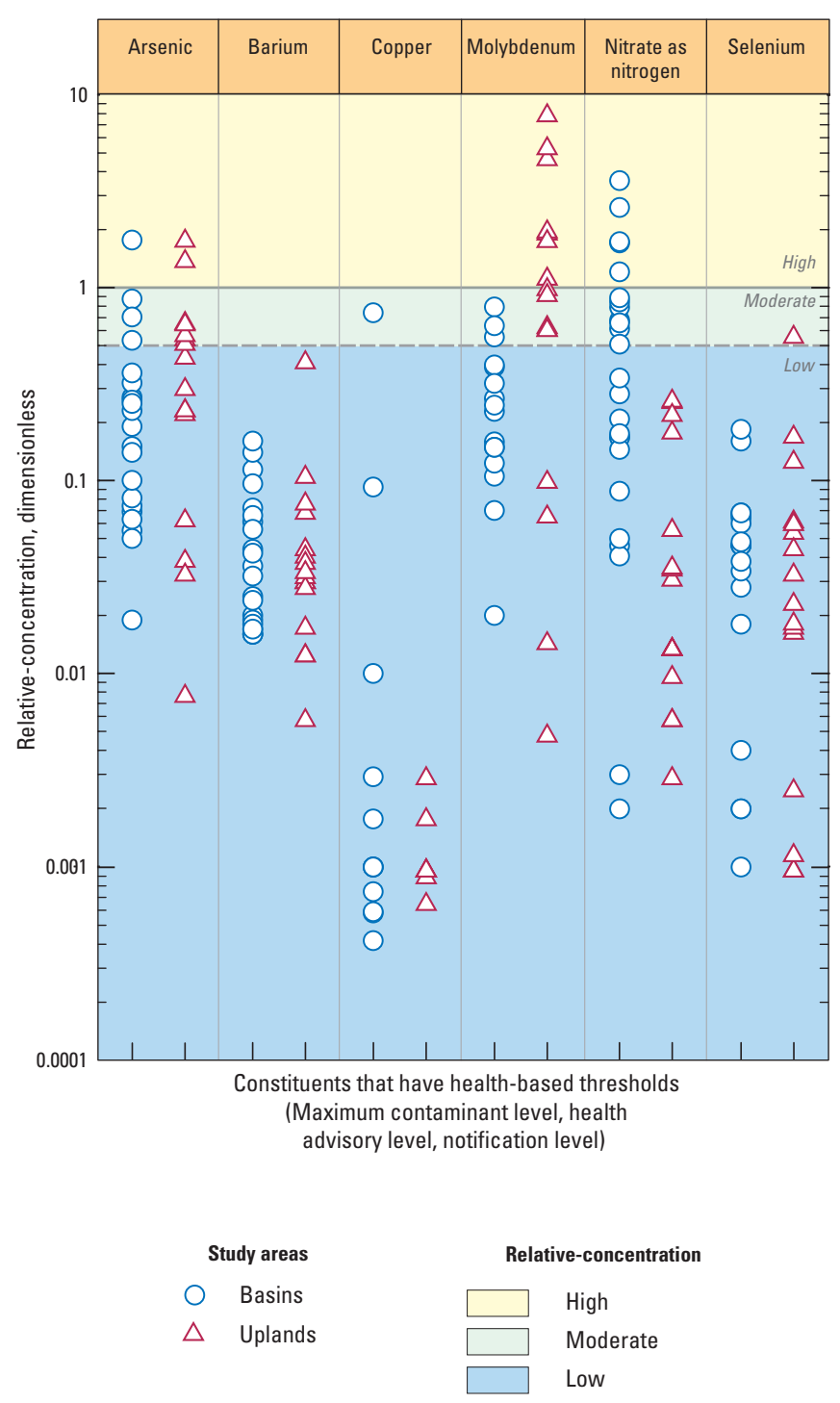

B

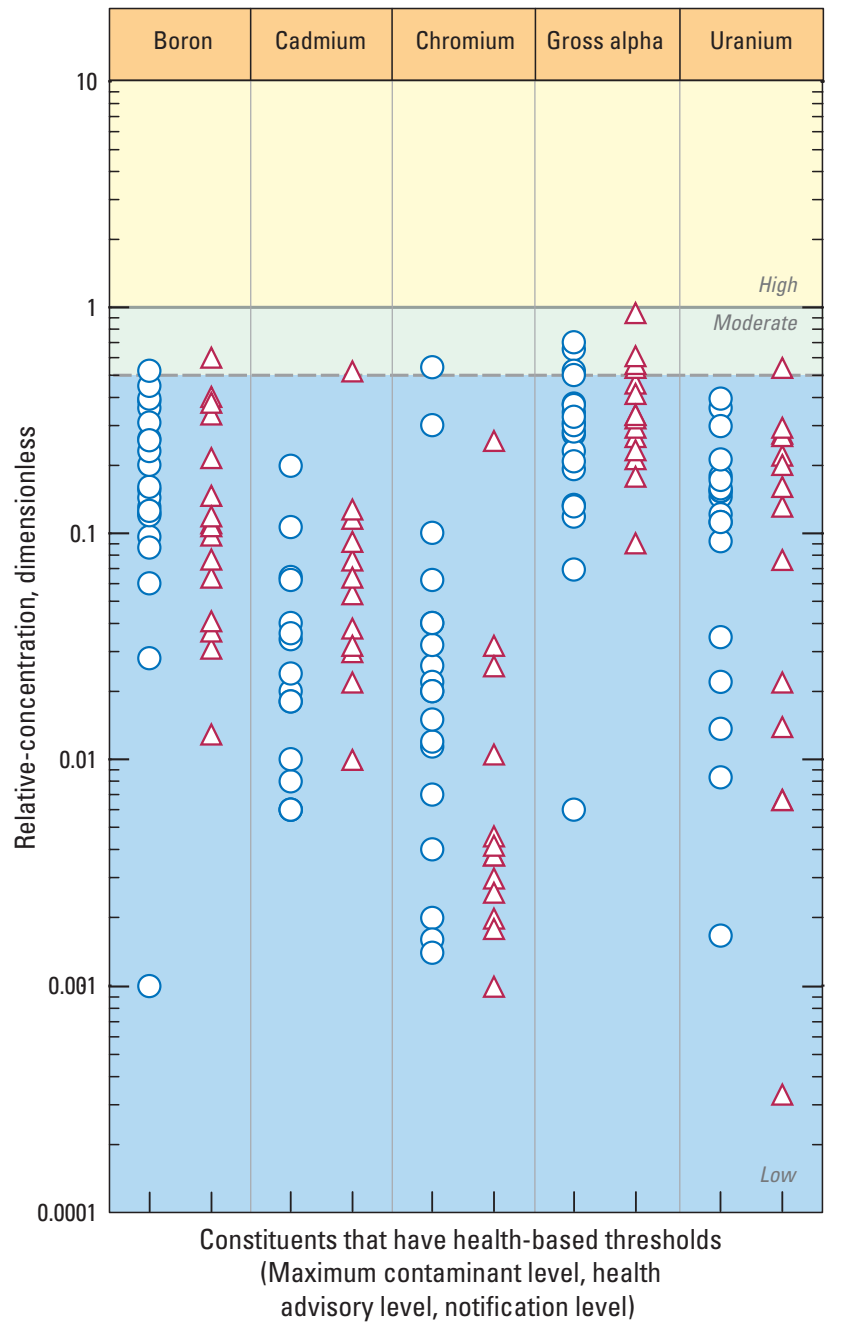

Relative-concentration

High

Moderate

Low

Figure 12. Relative-concentrations of inorganic constituents having $(A, B)$ human-health-based or $(C)$ SMCL benchmarks and high or moderate maximum relative-concentrations in USGS- and CDPH-grid wells, South Coast Range-Coastal study unit, California GAMA Priority Basin Project. 
C

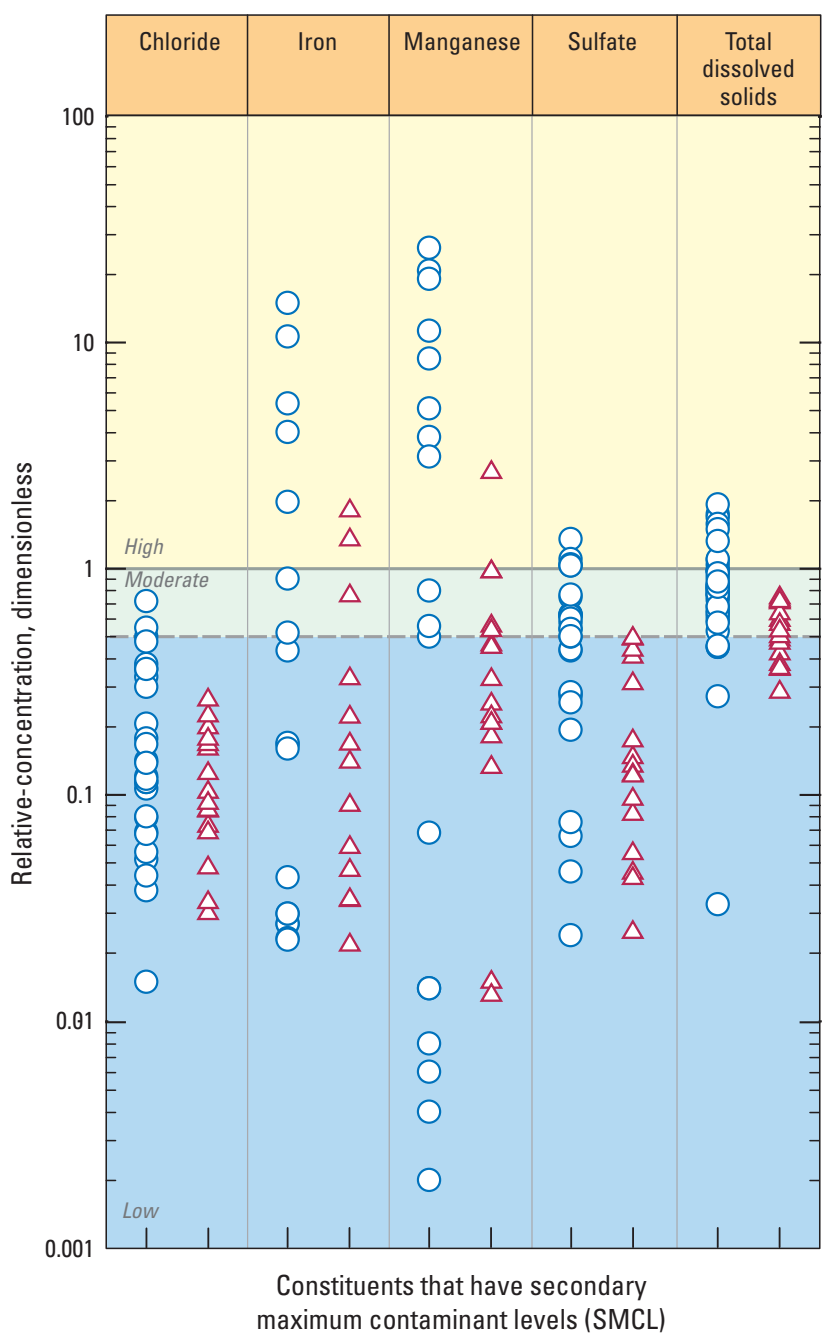

Figure 12.-Continued.

Arsenic mobilization and distribution in groundwater is affected by the oxidation-reduction (redox) and $\mathrm{pH}$ conditions of the groundwater system. Arsenic concentrations also can be higher in older groundwater because of extended exposure to arsenic-bearing minerals under the appropriate redox or $\mathrm{pH}$ conditions. Previous investigations of arsenic in other aquifers (Belitz and others, 2003; Welch and others, 2006; Izbicki and others, 2008) and literature reviews (Welch and others, 2000; Stollenwerk, 2003) have indicated two mechanisms for elevated arsenic: (1) the release of arsenic resulting from reductive dissolution of iron or manganese oxyhydroxides under iron- or manganese-reducing conditions, and (2) the $\mathrm{pH}$-dependent desorption of arsenic from aquifer sediments or inhibition of arsenic sorption to aquifer sediments under alkaline conditions, which tends to occur in groundwater with pH greater than 7 (Stollenwerk, 2003).

Evidence for the release of arsenic under reducing conditions in the Basins study area in the SCRC study unit includes the correlation of arsenic with manganese (rho = 0.512, $\mathrm{p}=0.002$ ). Most of the samples from the Basins study area with arsenic greater than $2 \mu \mathrm{g} / \mathrm{L}$ also had manganese concentrations greater than $50 \mu \mathrm{g} / \mathrm{L}$ (largely indicative of manganese-reducing conditions; fig. 14; table D3). Almost all of the arsenic detections greater than $2 \mu \mathrm{g} / \mathrm{L}$ are from groundwater samples of pre-modern or mixed ages (ig. 14A). This suggests that the accumulation of arsenic from the longer exposure to arsenic-bearing minerals under reducing conditions also may contribute to the elevated arsenic in the Basins study area.

Although reductive dissolution may be a possible mechanism for the occurrence of high relative-concentrations of arsenic in the Basins area, there is little evidence for this mechanism contributing to elevated arsenic concentrations in the Uplands study area. Arsenic is not correlated with either iron or manganese in the Uplands study area. However, most high and moderate concentrations of arsenic (5 of 7) in the Uplands study area are associated with DO concentrations less than $2 \mathrm{mg} / \mathrm{L}$ (fig. 14B), which indicates that some reduction dissolution may occur. While arsenic was not correlated to $\mathrm{pH}$ on the study-unit scale, arsenic was negatively correlated to $\mathrm{pH}$ in the Uplands (rho $=-0.568, \mathrm{p}=0.021$ ). This is different from what has been found in other GAMA study units where arsenic showed a positive correlation with pH (Kulongoski and others, 2010; Landon and others, 2010; Burton and others, 2012). This indicates that the second mechanism-preferential desorption from sediments under alkaline conditions-is not a major mechanism for elevated arsenic concentrations in the Uplands study area. It is unknown if the aquifer sediments in the Uplands study area contain more arsenic than the sediments in the Basins study area. It is possible that the higher arsenic concentrations in the Uplands study area may result from extended exposure of groundwater to arsenic-bearing minerals or arsenic adsorbed to minerals in the aquifer sediments in areas where DO is relatively low because the groundwater in the Uplands study area is generally pre-modern. 


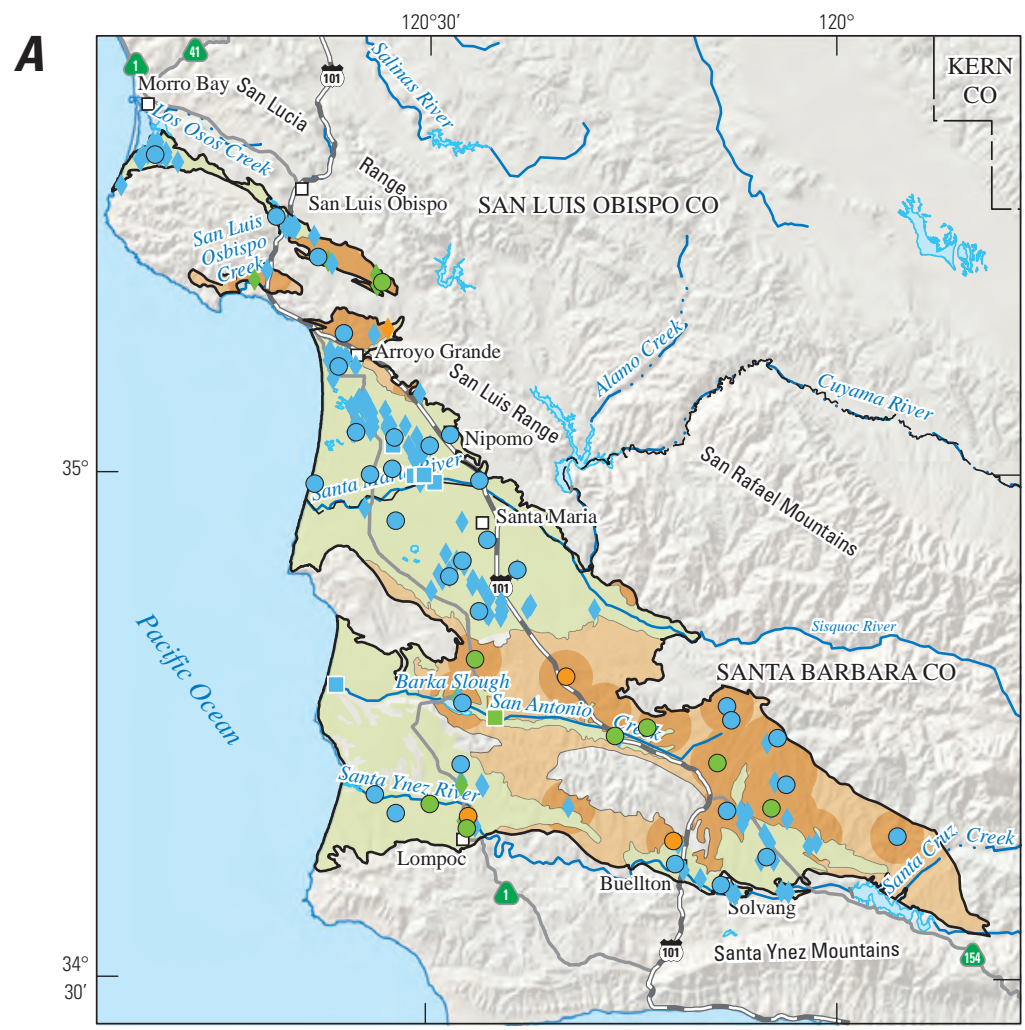

B

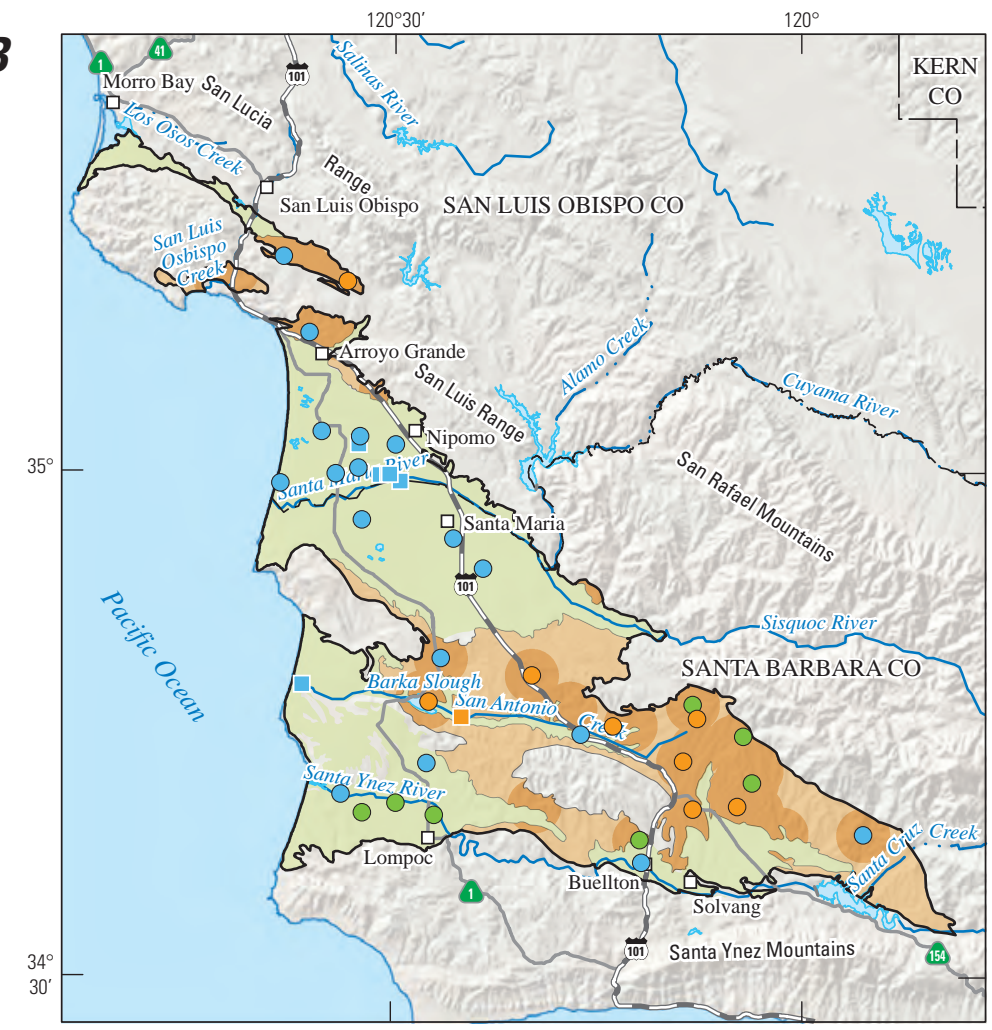

\section{EXPLANATION}

Study unit boundary רת

Relative-concentration
Relative-concentration

Low
$\begin{gathered}\text { Moderate } \\ \text { High }\end{gathered}$
Low
High

\section{Arsenic concentration, in micrograms per liter}

\section{Grid wells}

$\begin{array}{ll}0 & \leq 5 \\ 0 & >5 \text { to } \leq 10 \\ 0 & >10\end{array}$

Understanding wells

11. $\leq 5$

- $>5$ to $\leq 10$

Other CDPH wells

$$
\begin{aligned}
& \leq 5 \\
& >5 \text { to } \leq 10 \\
& >
\end{aligned}
$$

Shaded relief derived from U.S. Geological Survey National Elevation Dataset, 2006 Albers Equal Area Conic Projection

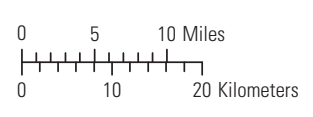

Molybdenum concentration, in micrograms per liter

Grid wells

$\begin{aligned} & \leq 20 \\ & >20 \text { to } \leq 40 \\ & >40\end{aligned}$

Understanding wells

$\square \leq 20$

- >40

Figure 13. Relative-concentrations of $(A)$ arsenic, $(B)$ molybdenum, and $(C)$ nitrate in USGS-grid and CDPH-grid wells and $\mathrm{CDPH}$-other wells in the South Coast Range-Coastal study unit, California GAMA Priority Basin Project. 

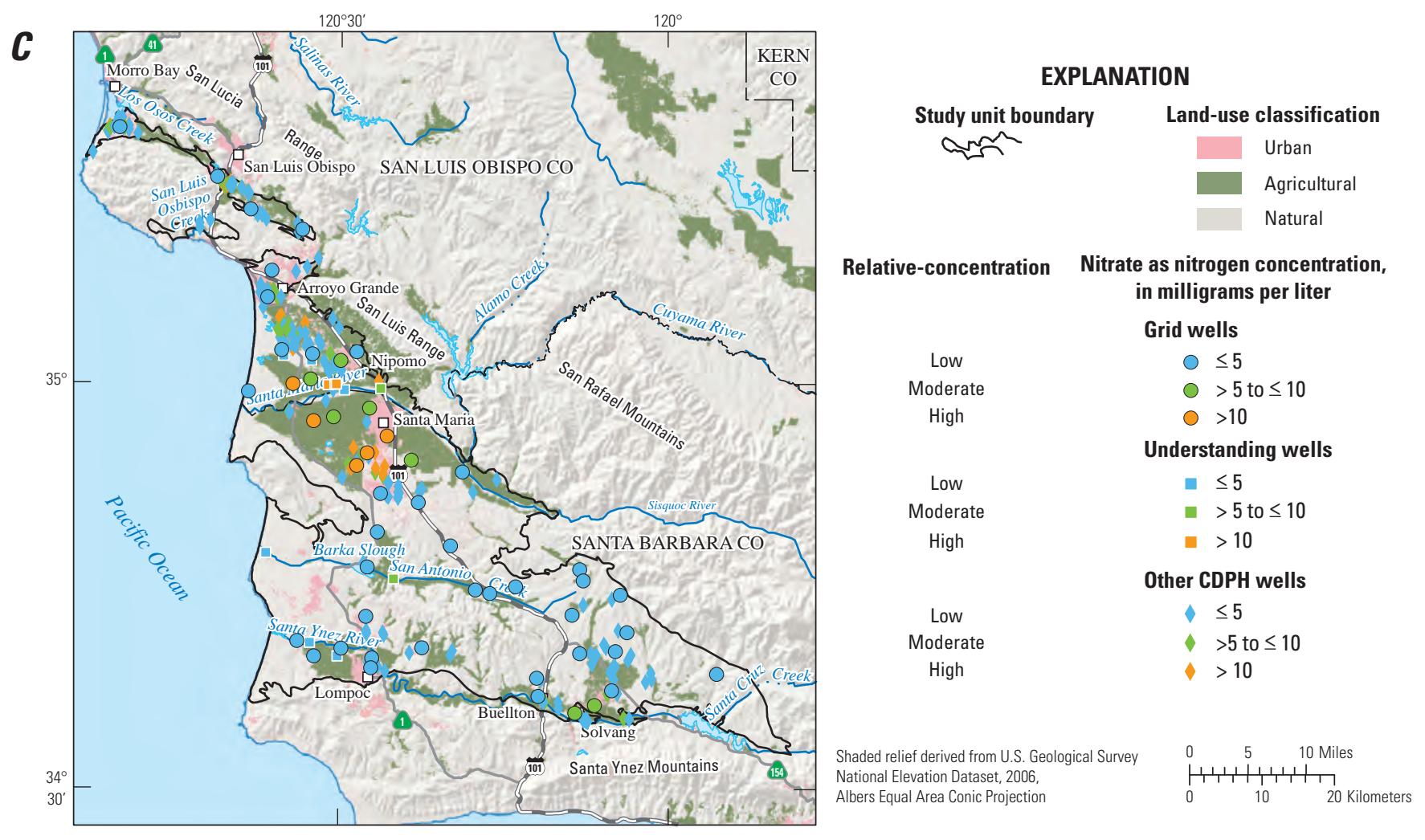

Figure 13.-Continued.

In summary, data indicate that the occurrences of elevated arsenic concentrations likely result from the release of naturally occurring arsenic from dissolution of manganese oxides under manganese-reducing conditions in the Basins study area and possible accumulation during relatively long residence times in the Uplands study area.

\section{Molybdenum}

Molybdenum is a metallic trace element used in highstrength steel alloys. The main natural source of molybdenum to groundwater is dissolution of molybdenum-bearing minerals in aquifer materials, the most common of which is the sulfide mineral molybdenite $\left(\mathrm{MoS}_{2}\right)$. Molybdenite generally forms in high-temperature environments and therefore occurs in many igneous and contact metamorphic rocks and may be present in fossil fuels. Molybdenum is more soluble under oxic conditions than anoxic conditions (Drever, 1997; Reimann and de Caritat, 1998). Potential anthropogenic sources include manufacture and use of molybdenum steel alloys, dry lubricants, and other industrial products (Hem, 1985). Molybdenum can readily accumulate in vegetation, especially for nitrogen-fixing species such as legumes. High levels of molybdenum in plants may be harmful to grazing animals (Reisenauer and others, 1973, as cited by Goldberg, 2009).

Molybdenum was detected at high relative-concentrations in 25 percent, and at moderate relative-concentrations in 22 percent of the primary aquifer system (table 8). High relative-concentrations of molybdenum occurred in the Uplands study area (figs. $12 A$ and $\underline{13 B}$ ). Moderate relativeconcentrations of molybdenum were detected in some USGSgrid wells in the Santa Ynez River Valley groundwater basin in the Basins study area. There were no data for molybdenum in the CDPH database for the SCRC study unit.

Molybdenum was positively correlated to well depth (table 10, fig. 15A) and positively correlated with arsenic $(\mathrm{rho}=0.738, \mathrm{p}<0.001$; fig. 15B). This indicates molybdenum may be released during reductive dissolution of the oxides, similar to arsenic. Molybdenum was not significantly correlated to groundwater age; however, almost all of the high and moderate relative-concentrations of molybdenum were found in wells with pre-modern groundwater (fig. 15A). 


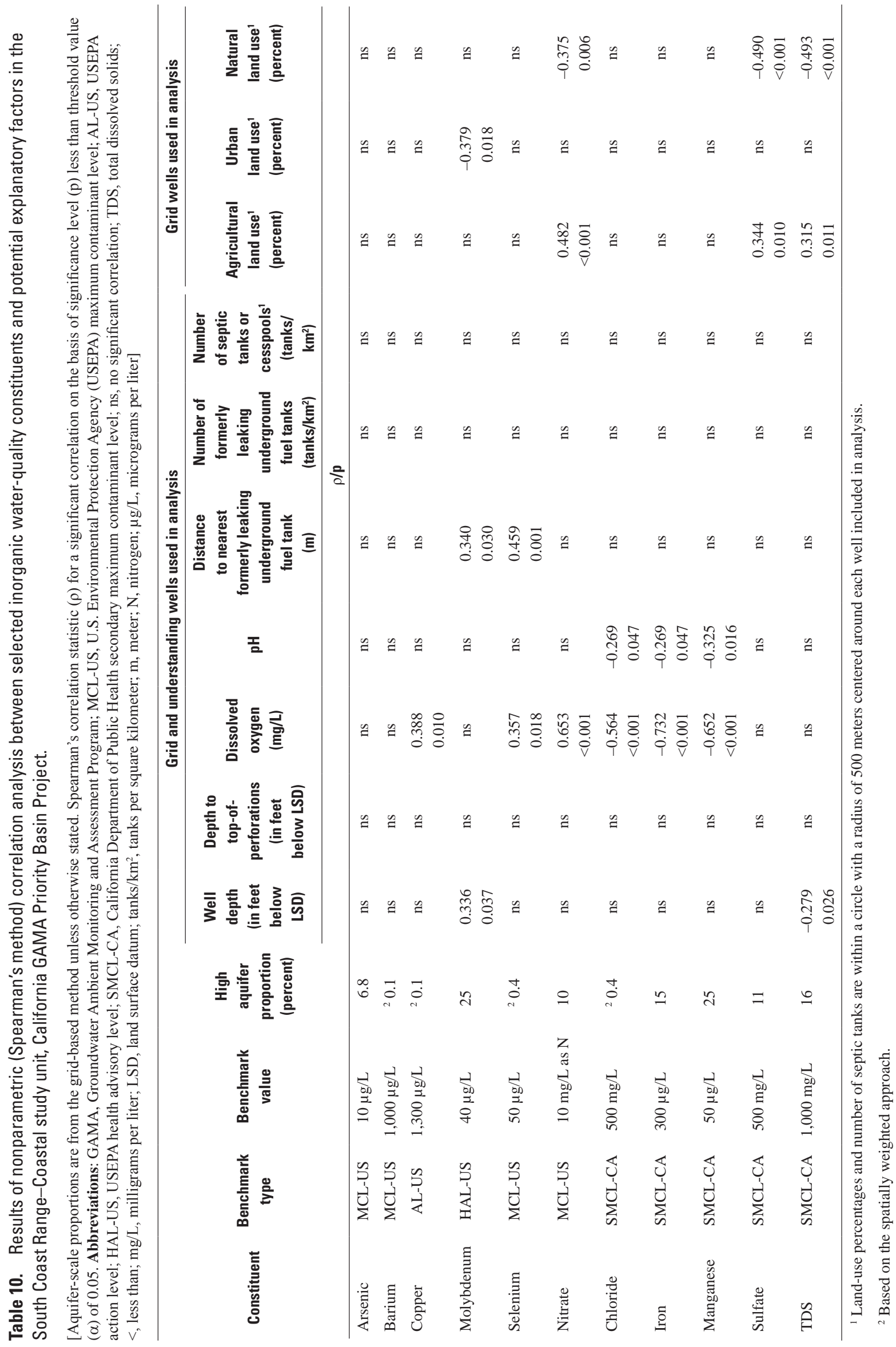


$\boldsymbol{A}$

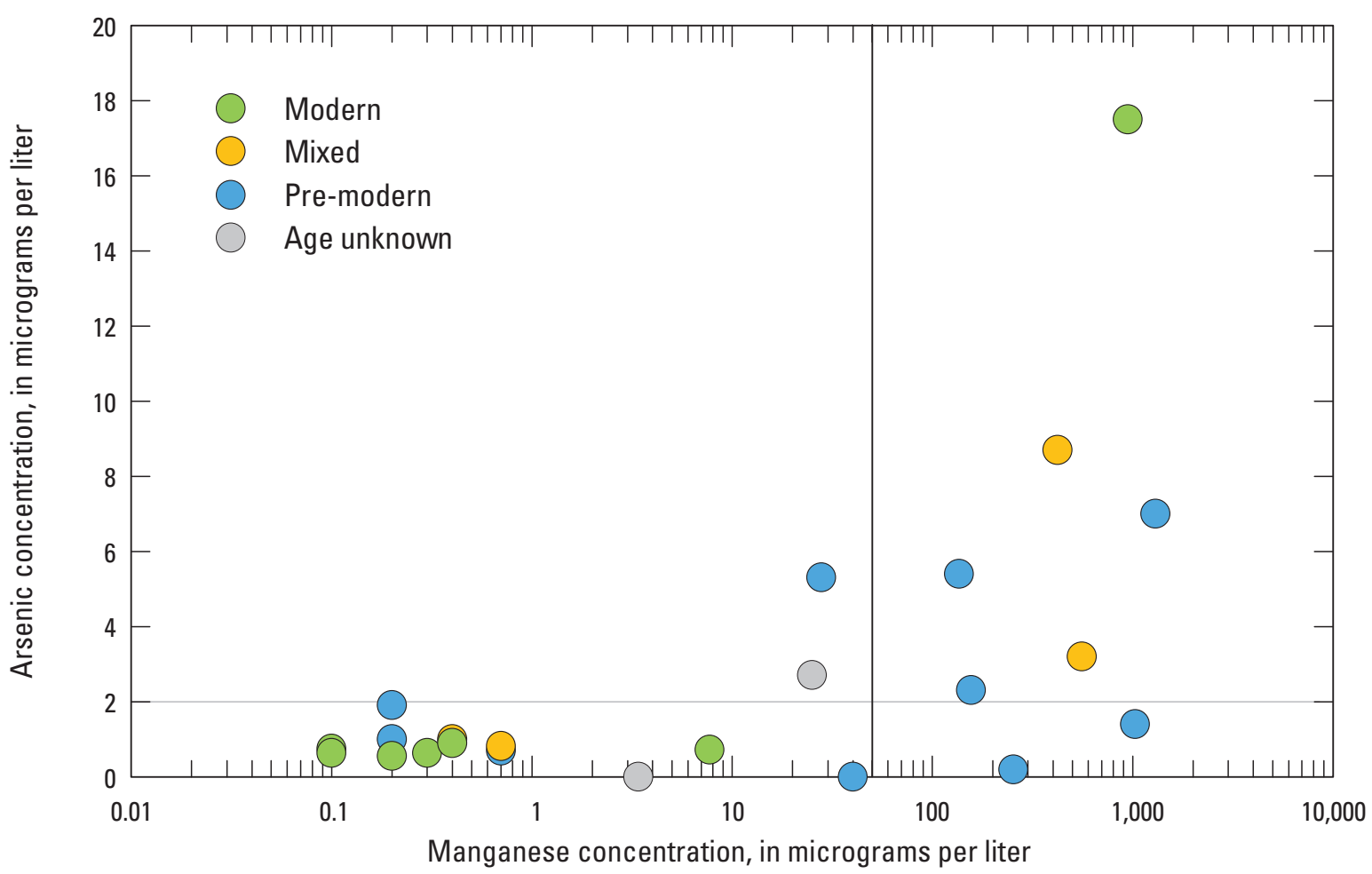

$\boldsymbol{B}$

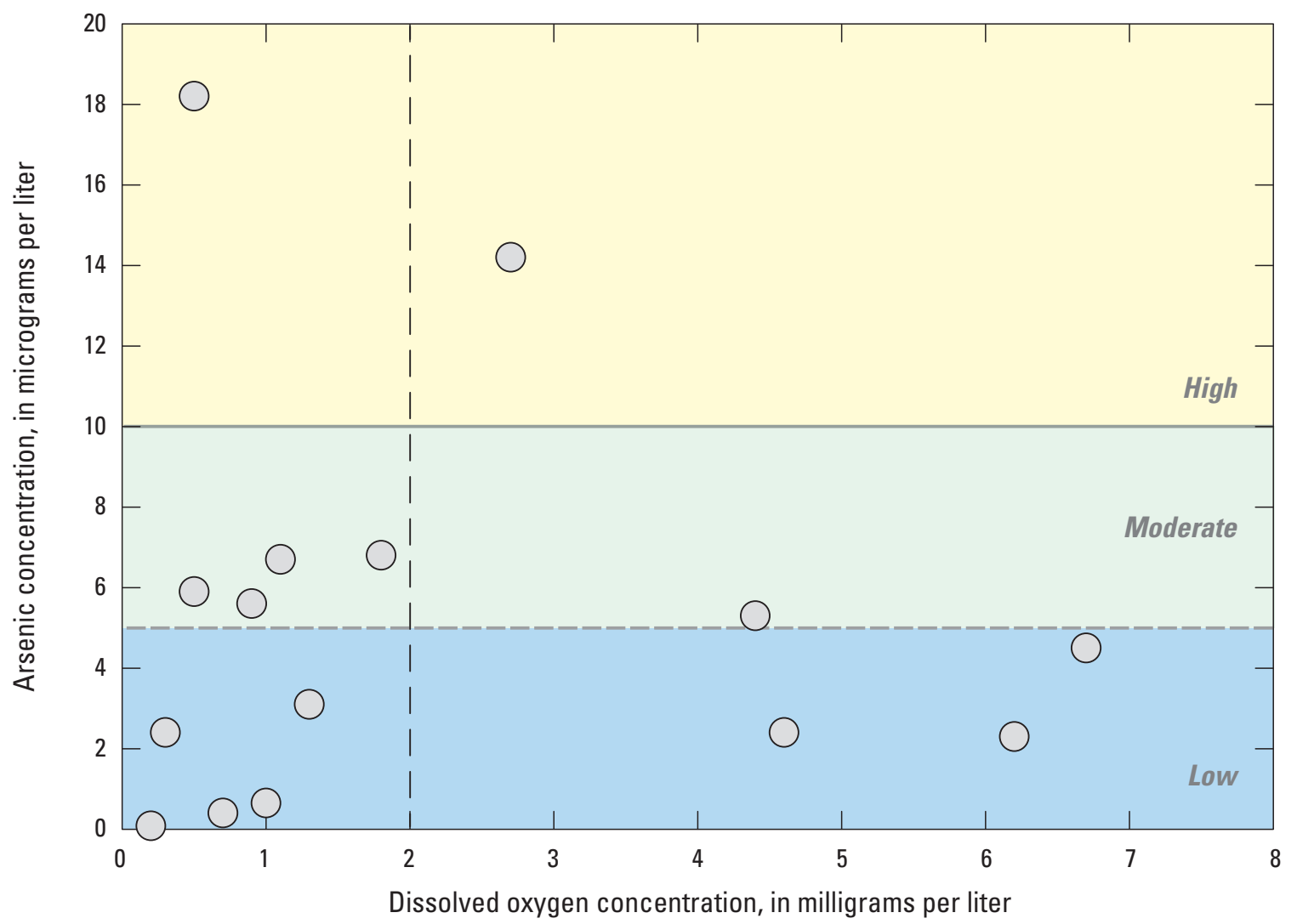

Figure 14. Relation of arsenic concentrations to $(A)$ manganese concentrations and groundwater age in the Basins study area and $(B)$ dissolved oxygen concentrations in the Uplands study area, South Coast RangeCoastal study unit, California GAMA Priority Basin Project. 
$\boldsymbol{A}$

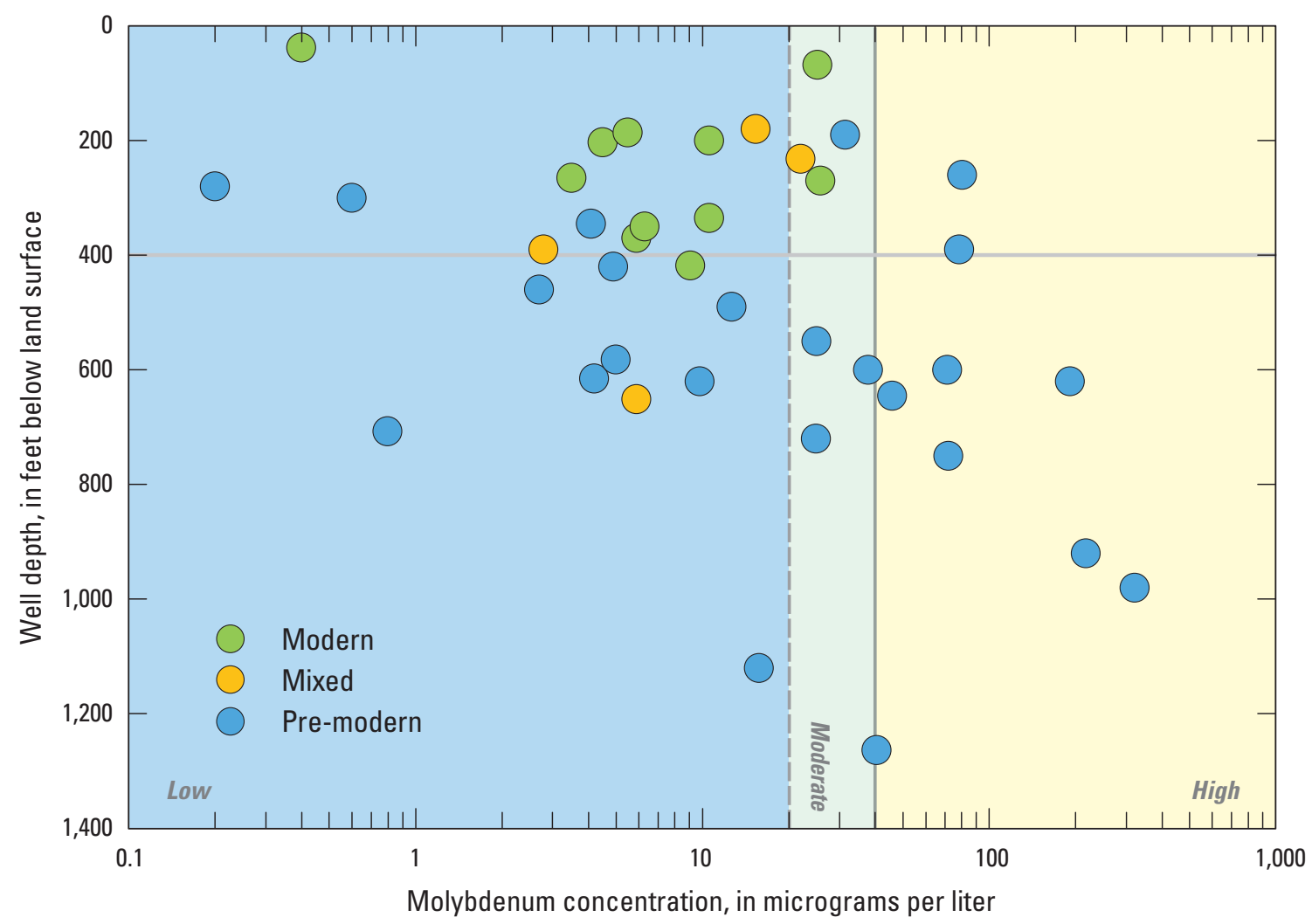

$\boldsymbol{B}$

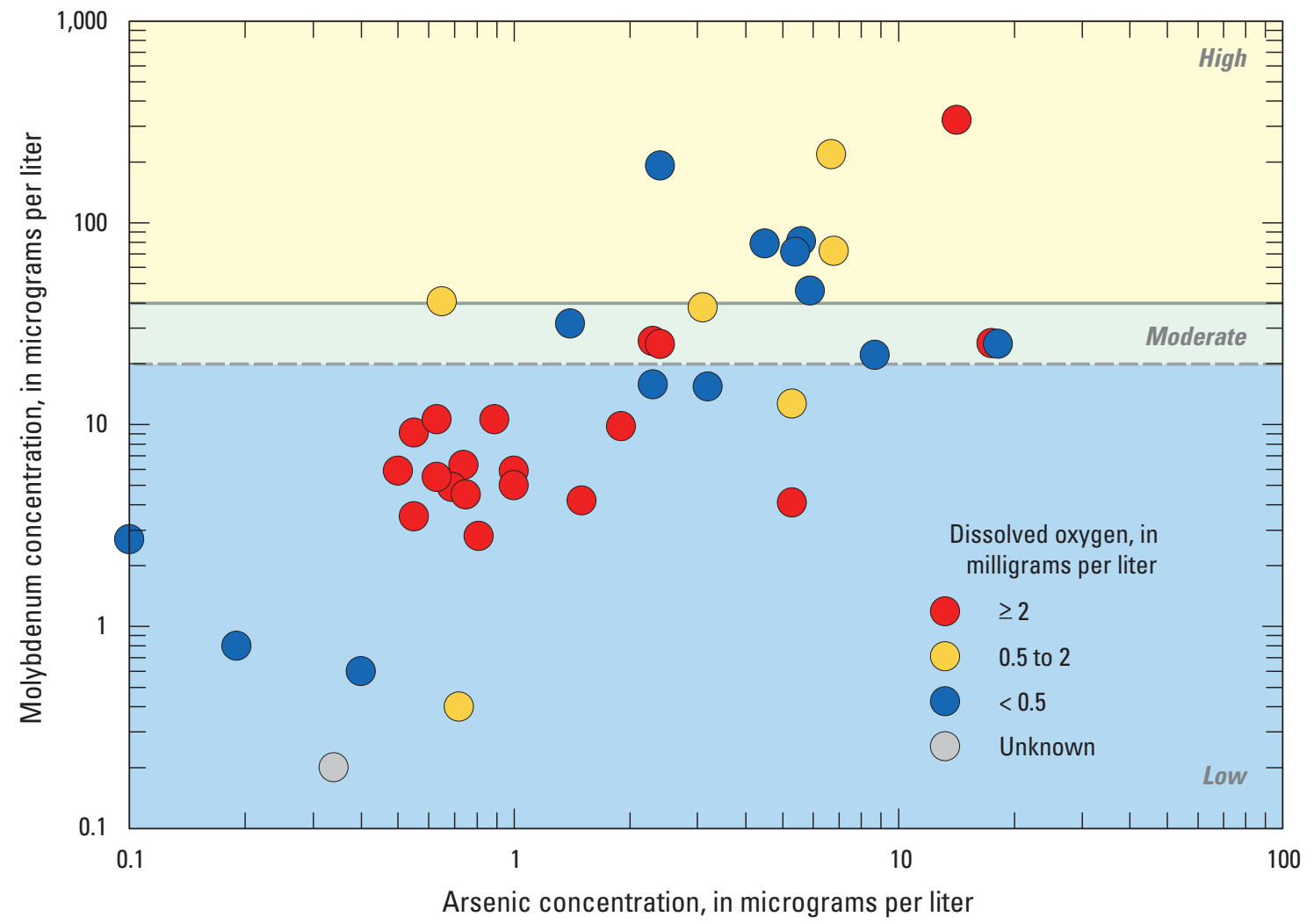

Figure 15. Relation of molybdenum concentrations to $(A)$ well depth and groundwater age and to $(B)$ arsenic and dissolved oxygen concentrations and $(C) \mathrm{pH}$ in wells with disolved oxygen greater than 0.5 milligram per liter, South Coast Range-Coastal study unit, California GAMA Priority Basin Project. 


\section{C}

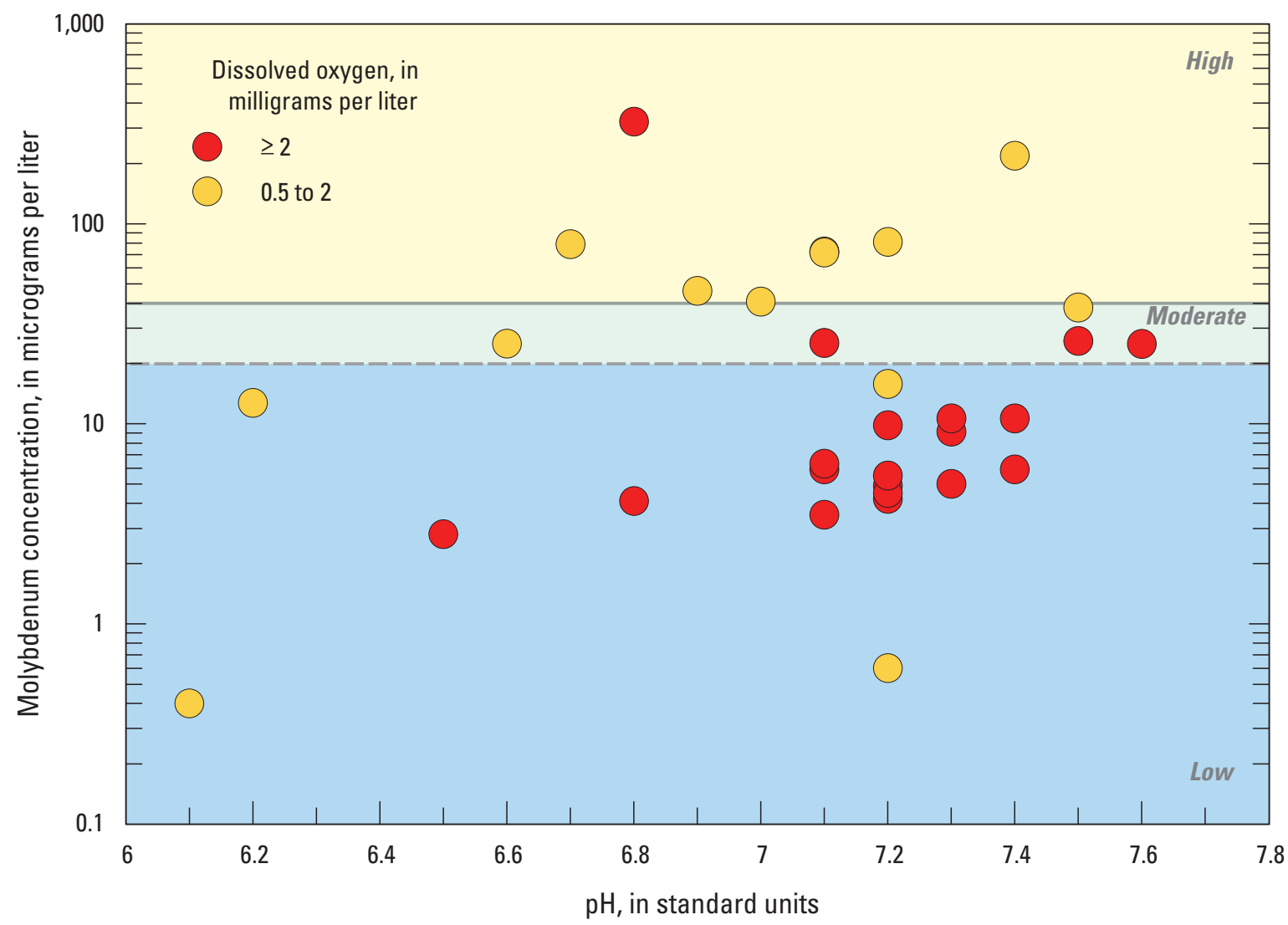

Figure 15.-Continued.

Molybdenum was not correlated with DO; however, most of the high and moderate relative-concentrations were in samples with DO less than $2 \mathrm{mg} / \mathrm{L}$ (fig. 15B). In addition, most of the high and moderate relative-concentrations of molybdenum were in groundwater that was suboxic or manganese-reducing. This observation is similar to what was found in some groundwater basins in the Sierras (Fram and Belitz, 2012). This observation indicates that the molybdate oxyanion, which is the major soluble species of molybdenum at $\mathrm{pH}$ greater than 5 , adsorbed to manganese oxide minerals is released during reductive dissolution of the oxides, similar to the release of arsenic resulting from reductive dissolution of iron or manganese oxides.

Dissolved molybdenum also can increase from $\mathrm{pH}$-dependent desorption of molybdenum from aquifer sediments under oxic conditions; this tends to occur in groundwater with $\mathrm{pH}$ greater than 4 (Goldberg, 2009), especially when groundwater is neutral or alkaline (Reimann and de Caritat, 1998). Molybdenum was not correlated with $\mathrm{pH}$ in the SCRC study unit (table 10). However, molybdenum concentrations tended to increase with $\mathrm{pH}$ when the DO concentration was greater than $0.5 \mathrm{mg} / \mathrm{L}$ (fig. 15C).
Molybdenum was negatively correlated to urban land use and positively correlated to the distance to the nearest LUFT (table 10). Molybdenum concentrations decreased as urban land use increased and the distance to the nearest LUFT increased. These correlations suggest that the primary source of elevated molybdenum is not from anthropogenic sources. The positive correlation of molybdenum with the distance to the nearest LUFT may reflect the correlation of LUFTs with urban land use rather than a direct relation of molybdenum with LUFTs or that the location of high and moderate molybdenum concentrations is in the Uplands study area where there is less urban and agricultural development than in the Basins study area.

In summary, molybdenum is from natural sources. High relative-concentrations of molybdenum occurred in the Uplands study area. Similar to arsenic, molybdenum concentrations may be influenced by the release of adsorbed molybdenum during reductive dissolution of manganese or iron oxides in reducing conditions. In oxic conditions, molybdenum concentrations may be influenced by pH-dependent desorption. 


\section{Nutrients}

The only nutrient with human-health benchmarks detected at high relative-concentrations in the study unit was nitrate plus nitrite (table 8). Nitrate plus nitrite was detected at high relative-concentrations in 10 percent of the primary aquifer system (table 9). Nitrite concentrations were negligible for wells sampled in the SCRC study unit (Mathany and others, 2010); therefore, nitrate plus nitrite is referred to as nitrate in this report.

\section{Nitrate}

Nitrogen in groundwater occurs in the forms of dissolved nitrate, nitrite, or ammonia. Certain bacteria and algae naturally convert nitrogen from the atmosphere to nitrate, which is an important nutrient for plants. Nitrate also is present in precipitation (Hem, 1970), partly from nitrogen oxides $\left(\mathrm{NO}_{\mathrm{x}}\right)$ released during the combustion of fossil fuels (Kendall, 1998). Anthropogenic sources of nitrate include its application as an inorganic fertilizer for agriculture and production by livestock of nitrogenous waste that can leach to groundwater when animals are present in concentrated numbers (Hem, 1985; Sparks, 2003). Septic and municipal sewage systems also contain nitrogenous waste that may leach into groundwater (Sparks, 2003).

Nitrate was detected at high relative-concentrations in 10 percent of the primary aquifer system in the SCRC study unit (table 8). High and moderate relative-concentrations of nitrate occurred in grid and understanding wells in the Basins study area (fig. 12A); specifically, high and moderate relativeconcentrations of nitrate were located in the Santa Maria River Valley groundwater basin (fig. 13C). Some moderate relativeconcentrations of nitrate also were detected in the Los Osos Valley and San Luis Obispo Valley groundwater basins to the north and in the upper Santa Ynez River Valley groundwater basin to the south (fig. 13C).

Nitrate was positively correlated with agricultural land use and negatively correlated with natural land use (table 10); nitrate concentrations were greater in areas with agricultural land use than in areas with urban or natural land uses (table 5). Elevated nitrate concentrations have been attributed to agricultural practices in the northern part of the Santa Maria River Valley near Arroyo Grande (California Department of Water Resources, 2002).

Nitrate was correlated to groundwater age (table 5) and positively correlated with DO in the SCRC study unit (table 10). Samples of modern groundwater have significantly higher nitrate concentrations than samples of mixed-age or pre-modern groundwater (table 5; fig. 16). Almost all of the moderate and high relative-concentrations of nitrate had DO concentrations greater than $2 \mathrm{mg} / \mathrm{L}$ (fig. 16). Almost all of the samples with very low (greater than $0.3 \mathrm{mg} / \mathrm{L}$ but less than or equal to $1 \mathrm{mg} / \mathrm{L}$ ) and ultra-low (less than or equal to $0.3 \mathrm{mg} / \mathrm{L}$ ) nitrate concentrations had DO concentrations less than $2 \mathrm{mg} / \mathrm{L}$. The positive correlation of nitrate, a redox-sensitive constituent, to DO indicates that nitrate is preserved in aerobic environments (Kendall, 1998) or that higher nitrate and DO tend to co-occur in modern, shallow groundwater and decrease with depth and age. Nitrate also was negatively correlated with manganese (rho $=-0.681, \mathrm{p}<0.001)$ and iron ( rho $=-0.649$, $\mathrm{p}<0.001$ ), which substantiates the prevalence of nitrate under oxidizing conditions. Reducing conditions mostly exist in parts of the Santa Ynez River Valley and San Antonio Creek Valley groundwater basins. Nitrate concentrations are low in those areas.

Unlike in other Priority Basin Project study units in California, nitrate was not correlated with well depth or depth to top-of-perforations (table 10) (Bennett and others, 2010; Landon and others, 2010; Kulongoski and others, 2010; Kulongoski and Belitz, 2011; Burton and others, 2011, 2012). Worts (1951) also did not see a relation of nitrate with depth in the Santa Maria River Valley area. However, high concentrations of nitrate were observed in shallow wells (top-of-perforations less than $100 \mathrm{ft}$ ) in the northern part of the Santa Maria River Valley groundwater basin (California Department of Water Resources, 2002). In the SCRC study unit, the relation of nitrate with well depth and depth to top-ofperforations may be complicated by the existence of shallow wells (well depth less than $400 \mathrm{ft}$ ) with low DO concentrations and pre-modern groundwater. Some of these shallow wells were located in the agricultural area near Lompoc; other wells were located in the Uplands study area or near the boundary of the Basins study area where there was less agricultural and urban development. These shallow wells are depicted on the left side of figure 16 where nitrate concentrations are categorized as ultra-low. Nitrate concentrations are negatively correlated with well depth (rho $=-0.406, p=0.012)$ if these shallow wells are omitted from the analysis.

In summary, nitrate concentrations in the SCRC study unit are influenced by a number of factors. Correlations of nitrate with agricultural and natural land use, groundwater age, and well depth indicate elevated concentrations result from human activities. In the SCRC study unit, nitrate concentrations are strongly influenced by redox conditions as indicated by relations with $\mathrm{DO}$, manganese, and iron.

\section{Uranium and Radioactive Constituents}

Uranium and other radioactive constituents occur naturally, primarily in granites, shale, and schist (Drever, 1997; Reimann and de Caritat, 1998). Uranium-238, thorium-232, and uranium-235 are the main sources of natural radioactivity in groundwater (Hem, 1985). Uranium-238 is the most common. Gross alpha radioactivity usually consists of isotopes of radium and radon which are part of the uranium and thorium radioactive decay series (Hem, 1985). In this study, the method used to analyze gross alpha radioactivity removes radon (Arndt, 2010); therefore, gross alpha radioactivity reported in this study results from the decay of uranium and radium. 


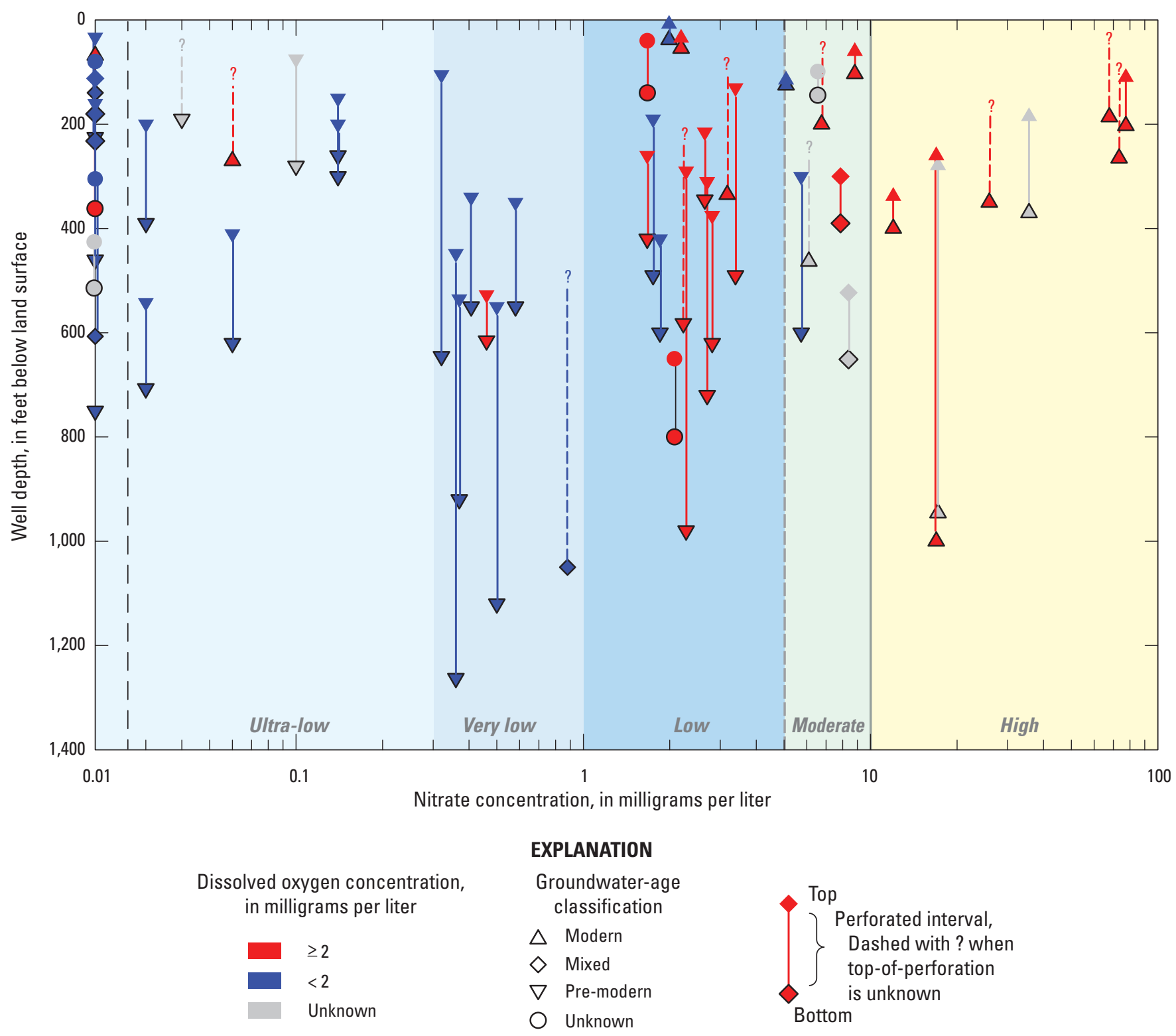

Figure 16. Relation of nitrate concentrations to dissolved oxygen concentrations, groundwater age, and well perforation intervals in the South Coast Range-Coastal study unit, California GAMA Priority Basin Project. 
Radioactive constituents were detected at moderate relative-concentrations in 5.0 percent and at low relativeconcentrations or not detected in 95 percent of the primary aquifer system in the SCRC study unit (table 9). Uranium had moderate relative-concentrations in 2.9 percent of the primary aquifer system, and gross alpha radioactivity had moderate relative-concentrations in 5 percent of the primary aquifer system (table 8; fig. 12).

\section{Inorganic Constituents with Aesthetic Benchmarks}

As a class, inorganic constituents with aesthetic benchmarks (SMCLs) were detected at high relativeconcentrations in 35 percent of the primary aquifer system and at moderate relative-concentrations in 55 percent (for one or more constituents; table 9). Inorganic constituents with aesthetic benchmarks that were detected at high relativeconcentrations in more than 2 percent of the primary aquifer system were iron, manganese, TDS, and sulfate (table 8). Chloride was detected at high relative-concentrations in less than 2 percent of the primary aquifer system and, therefore, is not discussed further in this report.

\section{Manganese and Iron}

Potential natural sources of manganese and iron to groundwater include the dissolution of igneous and metamorphic rocks as well as various secondary minerals (Hem, 1970) which can be mobilized under reducing or low pH conditions (McMahon and Chapelle, 2008). Potential anthropogenic sources of these constituents to groundwater include effluents associated with the steel and mining industries (Reimann and de Caritat, 1998) and soil amendments, in the form of manganese and iron sulfates, that are added to deficient soils to stimulate crop growth.

Manganese was detected at high relative-concentrations in 25 percent and at moderate relative-concentrations in 8.5 percent of the primary aquifer system in the SCRC study unit (table 8). High relative-concentrations of manganese occurred in USGS- and CDPH-grid wells mostly in the Basins study area (fig. 12C). Most of these high concentrations are in the Santa Ynez River and San Antonio Creek Valleys (fig. 17A). High relative-concentrations of manganese also were detected in some CDPH-other wells in the northern part of the Santa Maria River Valley (fig. 17A).

Iron was detected at high relative-concentrations in 15 percent and at moderate relative-concentrations in 6.4 percent of the primary aquifer system in the SCRC study unit (table 8). Most high relative-concentrations of iron in USGS- and CDPH-grid wells occurred in the Basins study area in parts of the Santa Ynez River Valley (fig. 17B). In addition, high relative-concentrations of iron were detected in CDPH-other wells in the northern part of Santa Maria River Valley. Distributions of high relative-concentrations of iron were similar to high relative-concentrations of manganese.
Distributions of manganese and iron concentrations are strongly influenced by redox conditions. Under anoxic conditions, reductive dissolution of manganese and iron oxides that commonly coat sediment particles increases the mobility of manganese and iron in aquifer systems (Sparks, 2003). Both manganese and iron were negatively correlated with DO in the SCRC study unit (table 10); these relations are expected if reductive dissolution is a significant pathway for the mobilization of manganese and iron in the primary aquifer system in the SCRC study unit. The negative correlations of manganese and iron with $\mathrm{pH}$ were not expected based on the lack of correlations observed in other coastal study units (Kulongoski and others, 2010; Kulongoski and Belitz, 2011; Mary Parsons, USGS, written commun., 2012) and may reflect that $\mathrm{pH}$ in the SCRC study unit was less than 8.

Manganese and iron concentrations were higher in mixed and pre-modern groundwater than in modern groundwater (table 5). Manganese and iron concentrations were not correlated to land use (table 10). In summary, higher manganese and iron concentrations in older and more reduced groundwater indicate mobilization from aquifer sediments as the primary source of manganese and iron in the SCRC study unit.

\section{Total Dissolved Solids}

Natural sources of TDS include seawater intrusion, mixing of groundwater in the primary aquifer system used for public supply with deep saline groundwater affected by interactions with deep marine and lacustrine sediments, concentration of salts by evaporation in discharge areas, and(or) rock/water interaction (Sparks, 2003). Potential anthropogenic sources of TDS to groundwater include concentration of salts by evaporation from agricultural and urban irrigation, disposal of wastewater and industrial effluent, and leaking water and sewer pipes (Sparks, 2003).

TDS was detected at high relative-concentrations in 16 percent and at moderate relative-concentrations in 66 percent of the primary aquifer system in the SCRC study unit (table 8). TDS concentrations are significantly higher in the Basins study area than in the Uplands study area (table 5). The high relative-concentrations of TDS in USGSand CDPH-grid wells occur in the Basins study area in the Santa Maria River and Santa Ynez River Valleys (figs. 12C and $\underline{17 C}$ ). Moderate relative-concentrations of TDS occur throughout the study unit.

TDS concentrations were significantly higher in wells with modern groundwater than in wells with pre-modern groundwater (table 5). TDS concentrations also were higher in areas with predominantly agricultural or urban land use than in areas with natural land use. Although TDS concentrations were statistically similar in groundwater collected from wells categorized as agricultural or urban (table D1), TDS concentrations were positively correlated only to the percentage of agricultural land use (table 10). Bright and others $(1992,1997)$ observed that TDS concentrations 

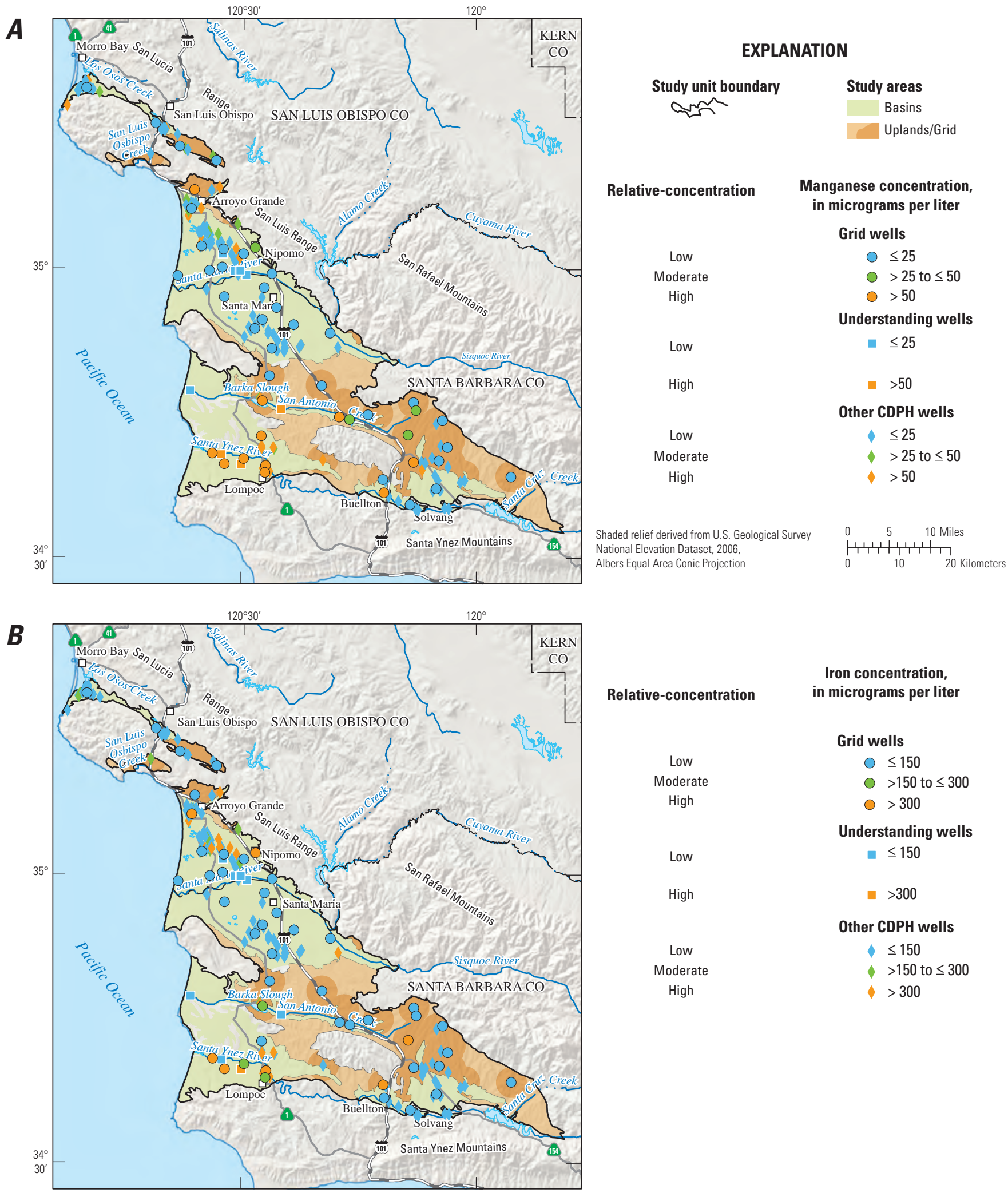

Relative-concentration

Iron concentration, in micrograms per liter

$\begin{gathered}\text { Low } \\ \text { Moderate } \\ \text { High }\end{gathered}$
Low
High
Low
$\begin{gathered}\text { Moderate } \\ \text { High }\end{gathered}$

Grid wells

$0 \leq 150$

- $>150$ to $\leq 300$

○ $>300$

Understanding wells

a $\leq 150$

- $>300$

Other CDPH wells

$\checkmark \leq 150$

$>150$ to $\leq 300$

$>300$

Figure 17. Relative-concentrations of $(A)$ manganese, $(B)$ iron, $(C)$ total dissolved solids, and $(D)$ sulfate in USGS-grid and CDPH-grid wells, USGS-understanding wells, and CDPH-other wells in the South Coast Range-Coastal study unit, California GAMA Priority Basin Project. 

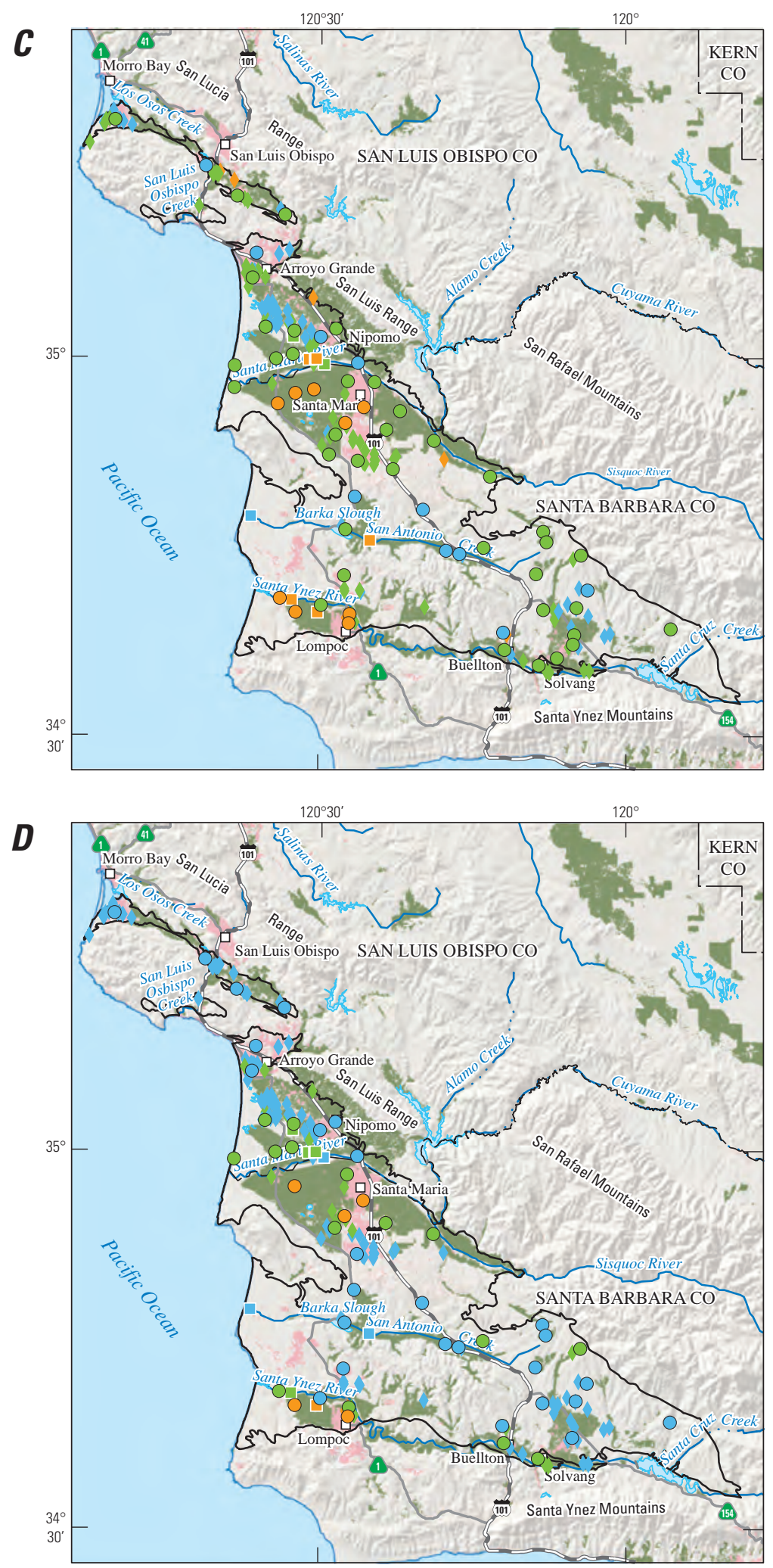

\section{EXPLANATION}

Study unit boundary $\overbrace{}^{n}$

Land-use classification

Urban Agricultural

Natural

Relative-concentration Total dissolved solids concentration, in milligrams per liter

Grid wells

$$
\begin{aligned}
& \leq 500 \\
0 & >500 \text { to } \leq 1,000 \\
& >1,000
\end{aligned}
$$

Moderate

Understanding wells

$$
\begin{aligned}
& \leq 500 \\
\square & >500 \text { to } \leq 1,000 \\
& >1,000
\end{aligned}
$$$$
\text { Low }
$$

Moderate

High

Low

Moderate

High

Other CDPH wells
$\leq 500$
$>500$ to $\leq 1,000$
$>1,000$

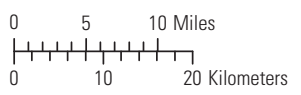

Shaded relief derived from U.S. Geological Survey National Elevation Dataset, 2006, Albers Equal Area Conic Projection

Relative-concentration

Sulfate concentration, in milligrams per liter

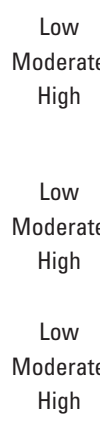

Grid wells

$$
\begin{aligned}
& \leq 250 \\
0 & >250 \text { to } \leq 500 \\
& >500
\end{aligned}
$$

Understanding wells

- $\leq 250$

- $>250$ to $\leq 500$

- $>500$

Other CDPH wells

$$
\begin{aligned}
& \leq 250 \\
& > \\
& >
\end{aligned}
$$

Figure 17.-Continued. 
increased in shallow zones in agricultural areas based on samples collected in the 1940s and late 1980s in the Lompoc area. Although Worts (1951) did not find a relation with well depth in the Santa Maria River Valley, the findings in this study were similar to those of Bright and others (1992, 1997), where TDS concentrations were negatively correlated with well depth (table 10). Other studies have shown that differences in TDS concentrations were found with depth in the alluvium and in the Paso Robles Formation in some areas of the SCRC study unit (California Department of Water Resources, 2002). In the Lompoc area, groundwater that was in contact with the consolidated rock of marine origin had higher concentrations of TDS than other groundwater (Bright and others, 1997). In summary, TDS concentrations are naturally occurring, but correlations with groundwater age, agricultural and urban land use, and well depth indicate that human activities may elevate TDS concentrations.

\section{Sulfate}

Sulfur occurs naturally in both igneous and sedimentary rocks as metallic sulfides. Pyrite crystals that occur in many sedimentary rocks are a major source of both ferrous iron and sulfate in groundwater (Hem, 1985). Sulfate also occurs in evaporate minerals such as gypsum (calcium sulfate) and is common in rainfall (Hem, 1970). The sulfate in rainfall has been attributed to the emission of hydrogen sulfide $\left(\mathrm{H}_{2} \mathrm{~S}\right)$ at the ocean margins, the combustion of fuels, the solution of dust particles, dissolution of gypsum or anhydrite, and the oxidation of uplifted fine-grained marine sediments (Hem, 1970). Sulfur also is applied as an agricultural fertilizer in parts of the SCRC study unit (California Department of Pesticide Regulation, 2008).

Sulfate was detected at high relative-concentrations in 11 percent and at moderate relative-concentrations in 32 percent of the primary aquifer system in the SCRC study unit (table 8). The distribution of sulfate is similar to the distribution of TDS. Sulfate concentrations are significantly higher in the Basins study area than in the Uplands study area (table 5; fig. 12C). The high relative-concentrations of sulfate occur in USGS-grid and understanding wells in the Basins study area in the south-central Santa Maria River Valley and parts of the Santa Ynez River Valley (fig. 17D).

Similar to TDS concentrations, sulfate concentrations were higher in wells with modern groundwater than in wells with pre-modern groundwater (table 5). Sulfate concentrations were significantly higher in areas with agricultural land use than in areas with natural land use (table 5), and were positively correlated with agricultural land use and negatively with natural land use (table 10). Sulfate concentrations were highly correlated to TDS concentrations (rho $=0.855$, $\mathrm{p}<0.001$ ). The correlation of sulfate with TDS indicates that sulfate contributes significantly to the composition of TDS. The correlations of sulfate with groundwater age and land use indicate that concentrations of sulfate may be elevated as a result of human activities.

\section{Organic Constituents}

Organic constituents (such as VOCs and pesticides), unlike inorganic constituents, usually are of anthropogenic origin. VOCs may be present in paints, solvents, fuels, and refrigerants, can be byproducts of water disinfection, and are characterized by their tendency to evaporate. Pesticides are used to control weeds, insects, or fungi in agricultural, urban, and suburban settings. Classes of organic compounds consisted of VOCs - which were further subdivided into trihalomethanes (THMs), solvents, and other VOCs—and pesticides.

Organic constituents with human-health benchmarks were detected at high relative-concentrations in 0.4 percent and at moderate relative-concentrations in 1.8 percent of the primary aquifer system in the SCRC study unit (table 9). The only class of organic constituents detected at high relativeconcentrations was solvents; both solvents and THMs were detected at moderate relative-concentrations. Other VOCs and pesticides with human-health benchmarks were detected at low relative-concentrations or were not detected (table 9). The THM chloroform, the solvent perchloroethene (PCE), and the refrigerant dichlorodifluoromethane (CFC-12) were organic constituents that were prevalent (detection frequency greater than 10 percent in USGS-grid wells) in the primary aquifer system (fig. 18). The detection frequencies and relativeconcentrations of selected organic compounds are shown in figure 19 in relation to the study area in which they were detected.

\section{Volatile Organic Compounds}

VOCs discussed in this report are classified as THMs, solvents, and other VOCs. More than one VOC was detected in 15 percent of the USGS-grid wells with VOC detections. Figure 20A shows the number of VOC detections in USGSgrid wells, USGS-understanding wells, and CDPH wells. Wells with more than one VOC generally were located in the Santa Maria River Valley groundwater basin. The number of VOC detections was not correlated with any of the explanatory factors evaluated (ables 5 and $\underline{11})$. 


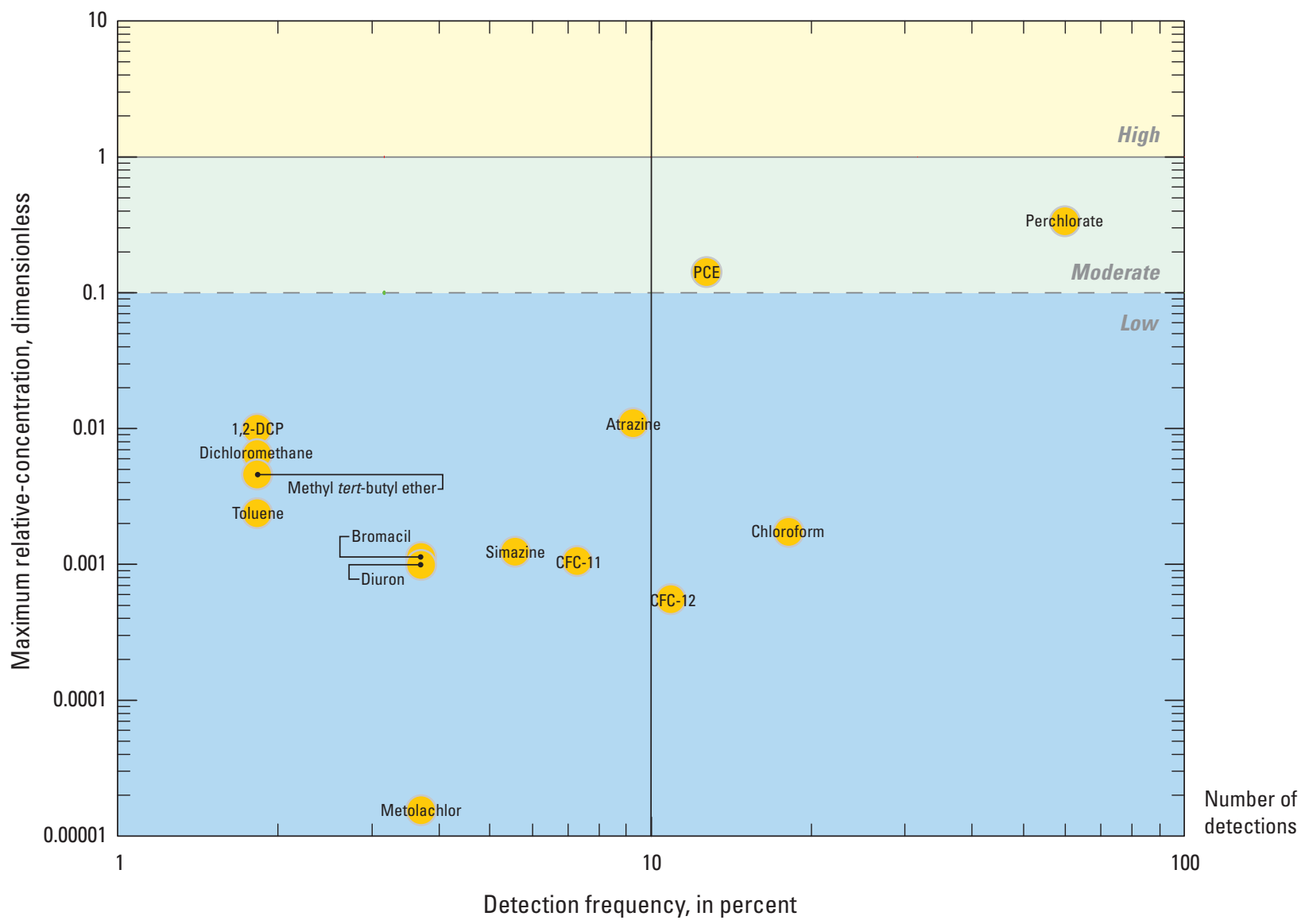

\section{EXPLANATION}

Simazine Name and center of symbol is the maximum relative-concentration for that constituentUnless indicated by following location line:

Figure 18. Detection frequencies and maximum relative-concentrations of organic and special-interest constituents detected in USGS-grid wells in the South Coast Range-Coastal study unit, California GAMA Priority Basin Project. 

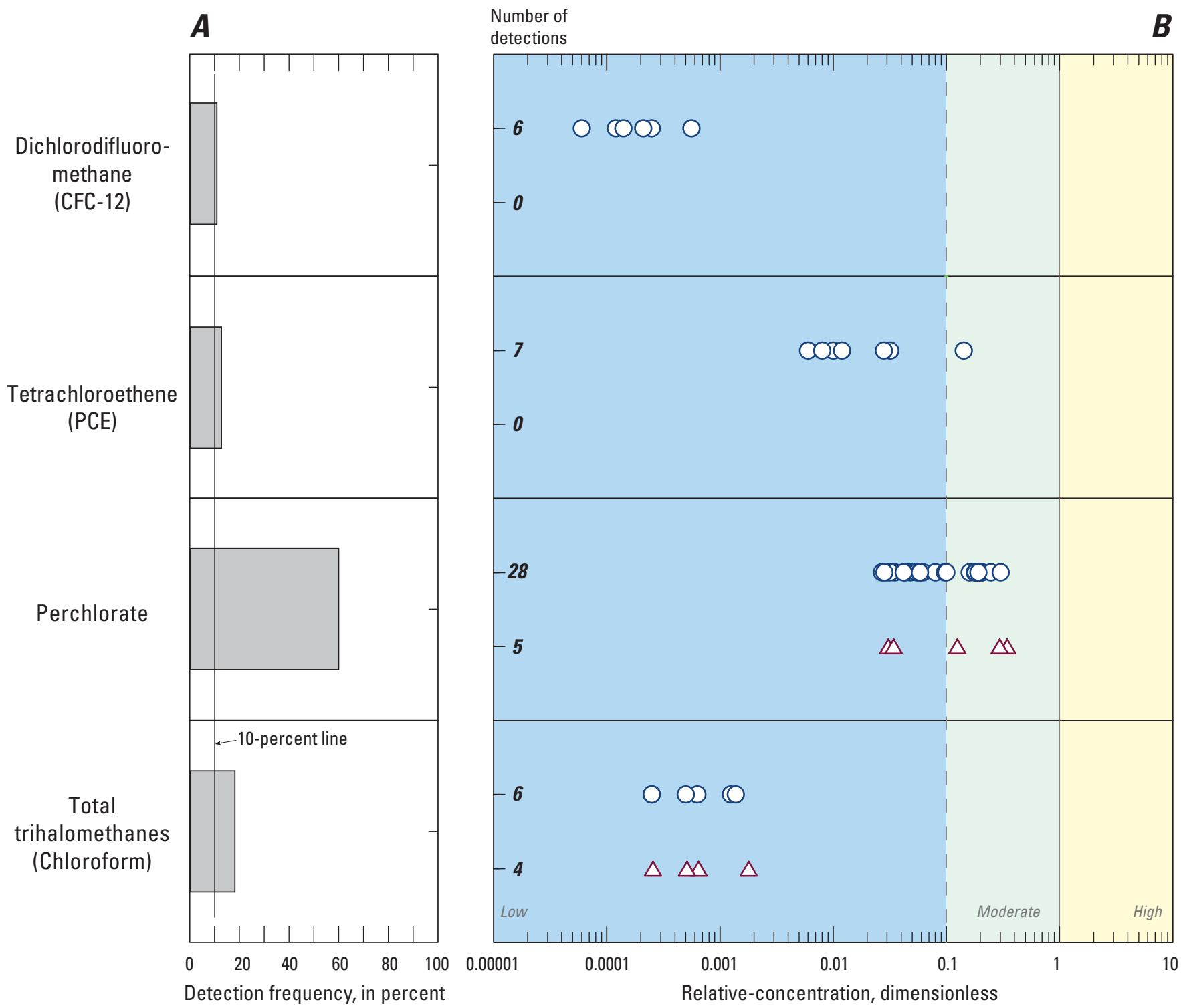

\section{EXPLANATION}

\begin{tabular}{cc}
\multicolumn{2}{c}{ Study areas } \\
$\bigcirc$ & Basins \\
$\Delta$ & Uplands
\end{tabular}

Relative-concentration

High

Moderate

Low

Figure 19. (A) Detection frequencies and $(B)$ relative-concentrations of selected organic and special-interest constituents in USGS-grid wells in the South Coast Range-Coastal study unit, California GAMA Priority Basin Project. 


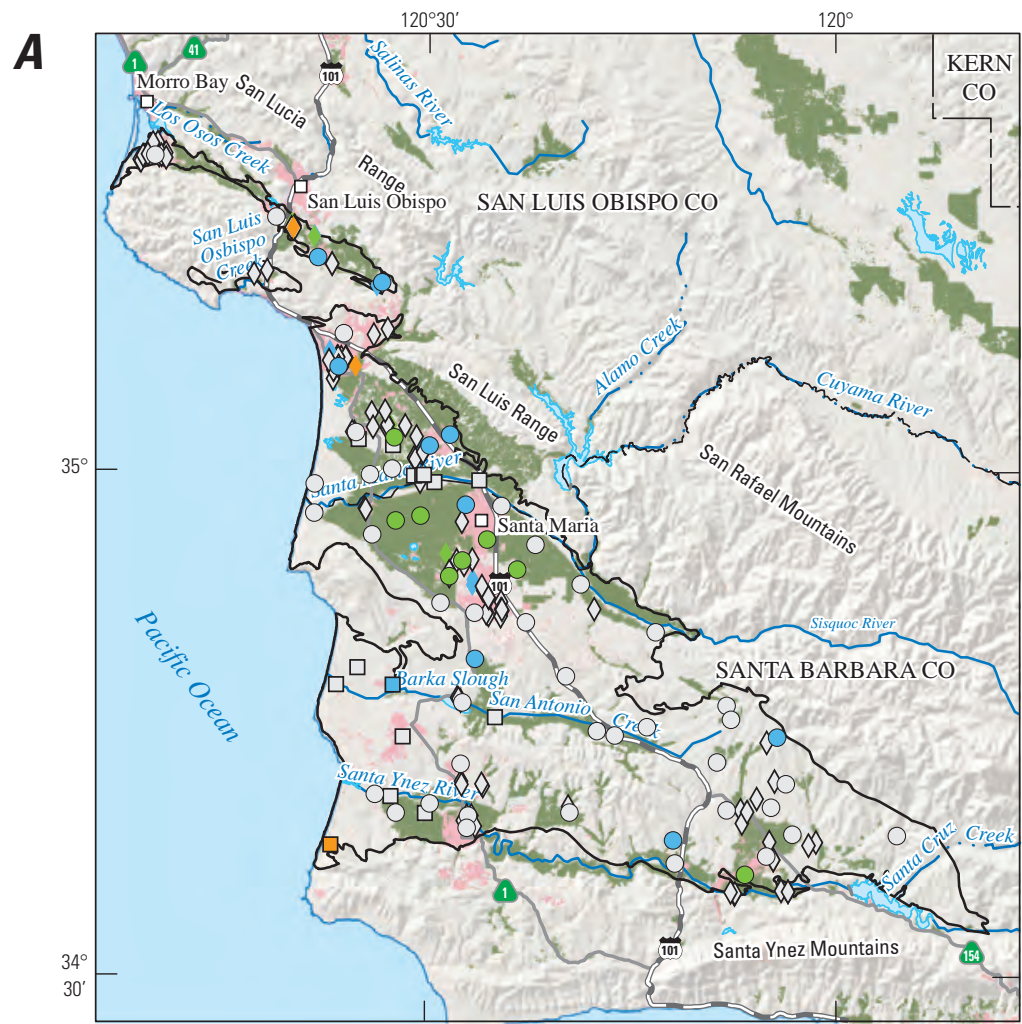

\section{EXPLANATION}

Study unit boundary רก

Land-use classification

Urban

Agricultural

Natural

Volatile organic compound (VOC) detections

USGS-grid wells

O No detections

- 1 VOC

- 2 to 3 VOCs

USGS-understanding wells

$\square$ No detections

$\square 1 \mathrm{VOC}$

$\square>5 \mathrm{VOCs}$

CDPH wells

$\diamond$ No detections

1 VOC

- 2 to 3 VOCs

$>3 \mathrm{VOCs}$

Shaded relief derived from U.S. Geological Survey National Elevation Dataset, 2006 Albers Equal Area Conic Projection

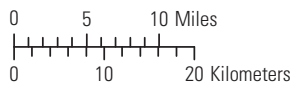

\section{$\boldsymbol{B}$}

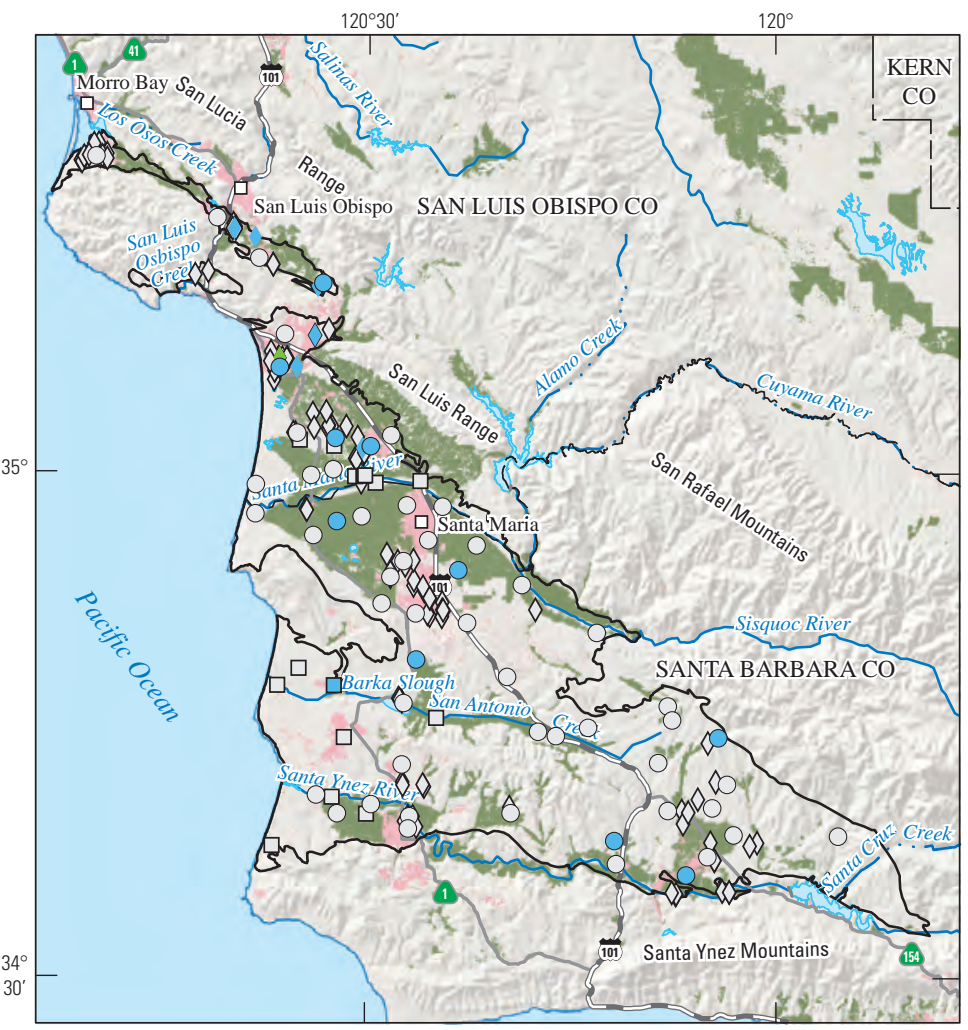

Relative-concentration

Low

Low

Low

Moderate
Total trihalomethane (TTHM) concentrations, in micrograms per liter

USGS-grid wells

$\bigcirc$ No detections

$0 \leq 8$

USGS-understanding wells

$\square$ No detections

$\square \leq 8$

CDPH wells

$\diamond$ No detections

$\leq 8$

$\checkmark>8$

Figure 20. (A) Number of volatile organic compound (VOC) detections, $(B)$ trihalomethane (chloroform) concentrations, $(C)$ perchloroethene (PCE) concentrations, $(D)$ number of other VOC detections, and $(E$ ) number of pesticide detections in USGSgrid and USGS-understanding wells, and CDPH-wells in the South Coast Range-Coastal study unit, California GAMA Priority Basin Project. 

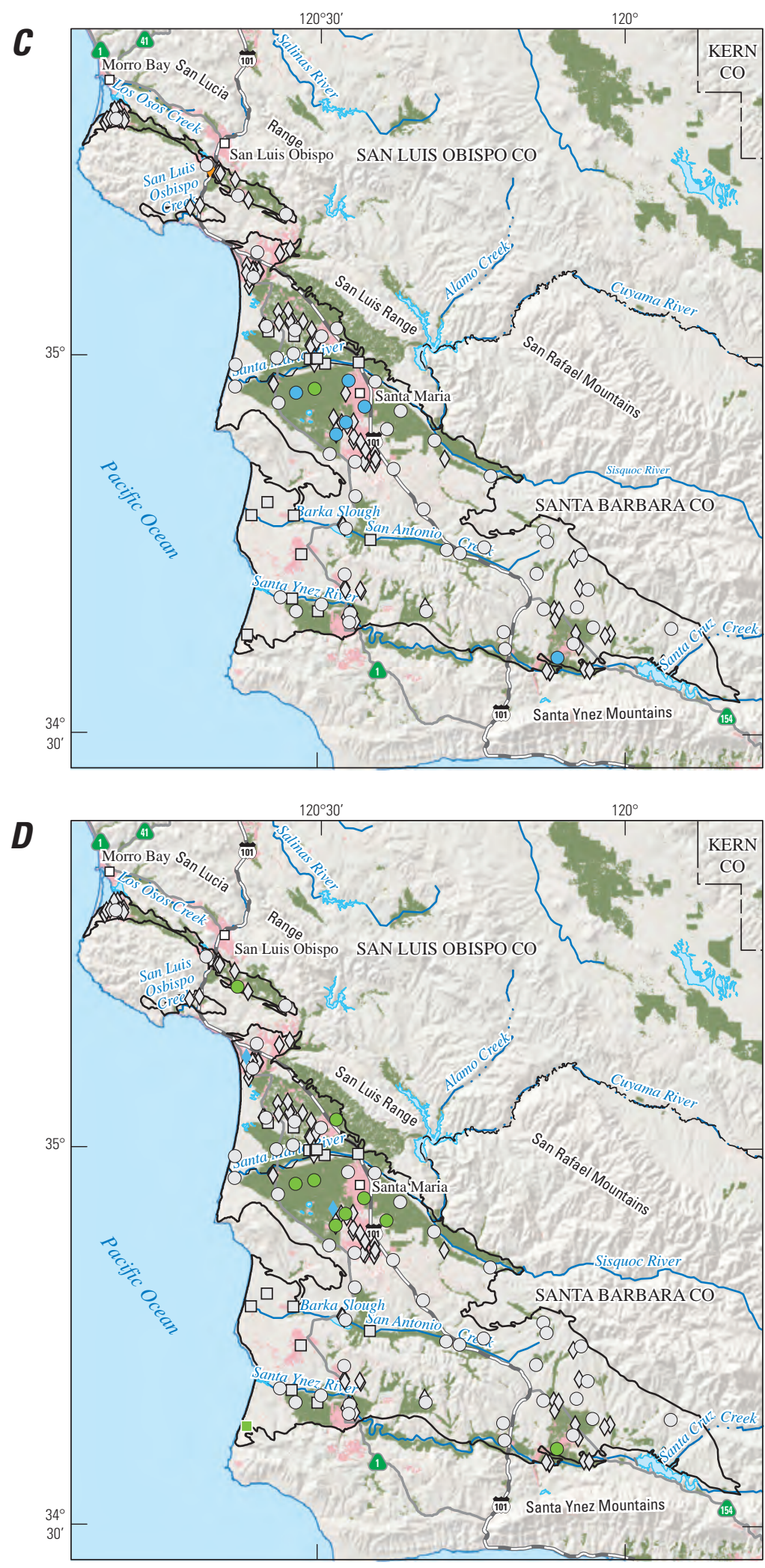

Figure 20.-Continued.

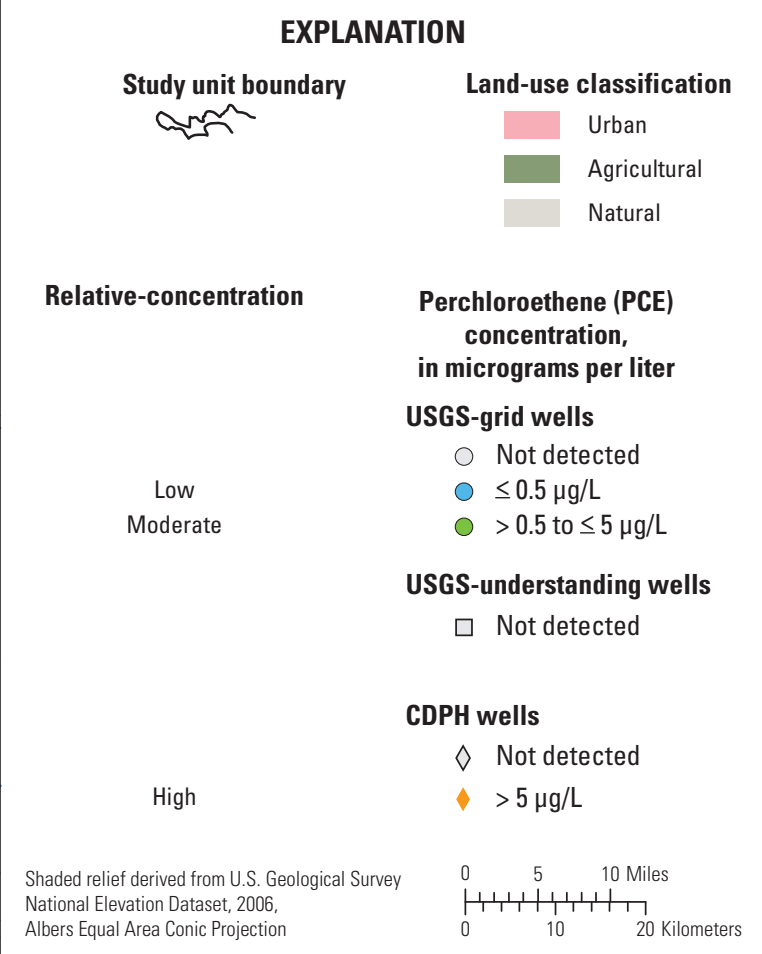

Other volatile organic compound (VOC) detections
USGS-understanding wells

$\square$ No detections

- 2 Other VOCs

CDPH wells

$\diamond$ No detections

$\checkmark 1$ Other VOC 

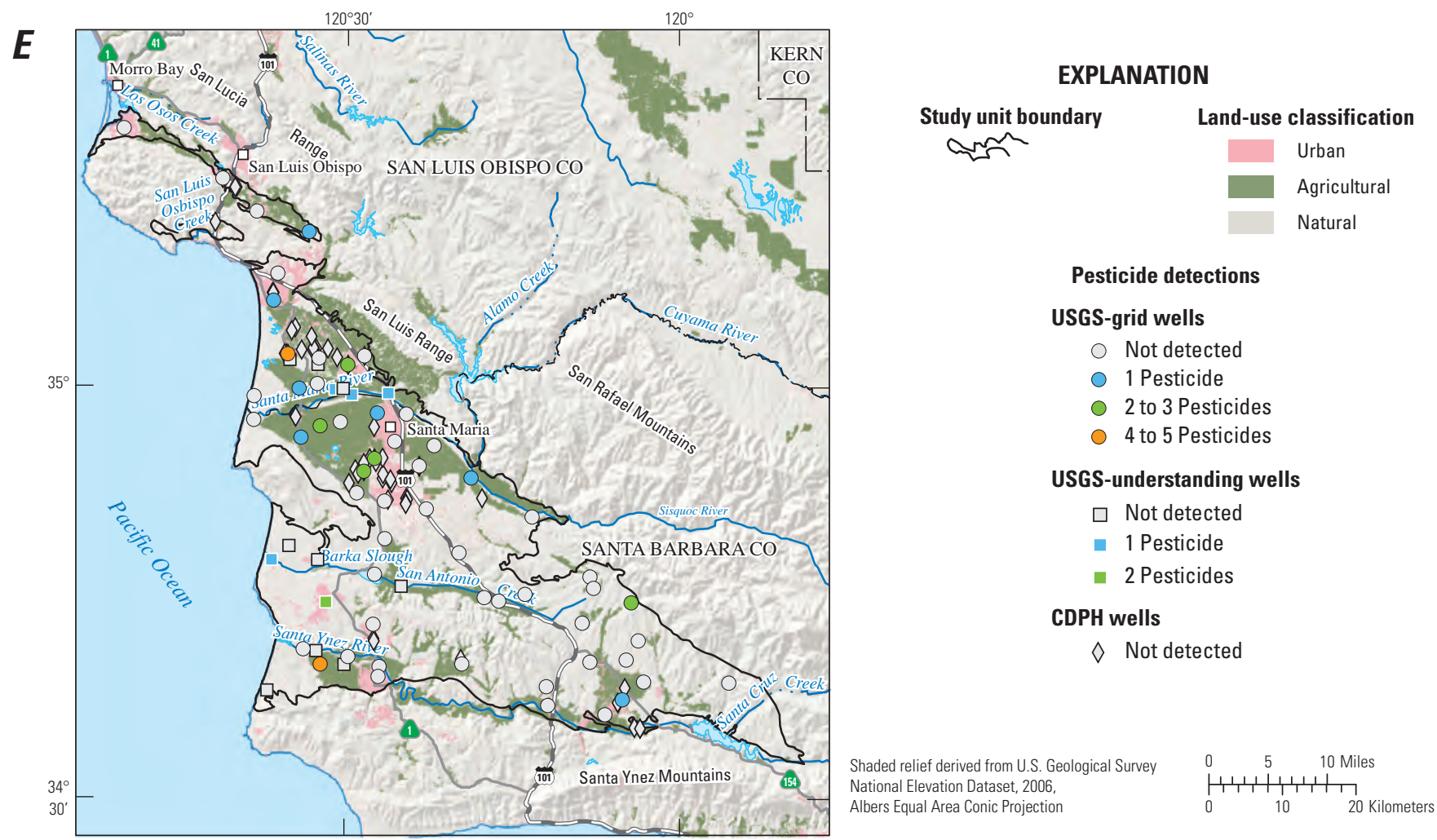

Figure 20.-Continued.

\section{Trihalomethanes (Chloroform)}

Water used for drinking water and other household uses in both domestic and municipal systems commonly is disinfected with chlorine solutions (bleach). As a side effect of disinfection, the chlorine reacts with organic matter to produce THMs and other chlorinated and/or brominated disinfection byproducts. The THMs analyzed in this study were chloroform, bromodichloromethane, dibromochloromethane, and bromoform. Chloroform, the only THM detected, was present at low relative-concentrations in the primary aquifer system (fig. 19B) with a detection frequency of 18 percent (fig. 18). Chloroform was detected in both study areas (figs. 19B and 20B). Nationally, chloroform was the most frequently detected VOC in aquifers in studies conducted by the USGS National Water-Quality Assessment Program (NAWQA; Zogorski and others, 2006).

In the SCRC study unit, chloroform concentrations were positively correlated with the number of septic tanks or cesspools (table 11). Chloroform concentrations were not correlated with urban land use or modern groundwater as has been found in other GAMA Priority Basin Project study units (Kulongoski and others, 2010; Landon and others, 2010; Fram and Belitz, 2012). Nationally, chloroform and THMs have been strongly correlated with percentage of urban land use (Zogorski and others, 2006).

\section{Perchloroethene (PCE) and Other Solvents}

Solvents are used for various industrial, commercial, and domestic purposes. PCE is a solvent that is primarily used for dry cleaning of fabrics and degreasing metal parts and is an ingredient in a wide range of products, including paint removers, polishes, printing inks, lubricants, and adhesives. Trichloroethene (TCE) is a degradate of PCE under reducing conditions (Vogel and McCarty, 1985; Russell and others, 1992). Solvents as a class had a high aquifer-scale proportion of 0.4 percent and a moderate aquifer-scale proportion of 1.8 percent of the primary aquifer system (table 9 ). The solvents PCE and TCE had spatially weighted high aquiferscale proportions of 0.3 and 0.1 percent of the primary aquifer system, respectively (table 8). PCE also had a detection frequency of 13 percent (fig. 18 and $\underline{19 A}$ ) and was detected at moderate relative-concentrations in 2 percent of the primary aquifer system (table 8). All of the PCE detections were in the Basins study area (ig. 19B), mostly near the city of Santa Maria (fig. 20C). 


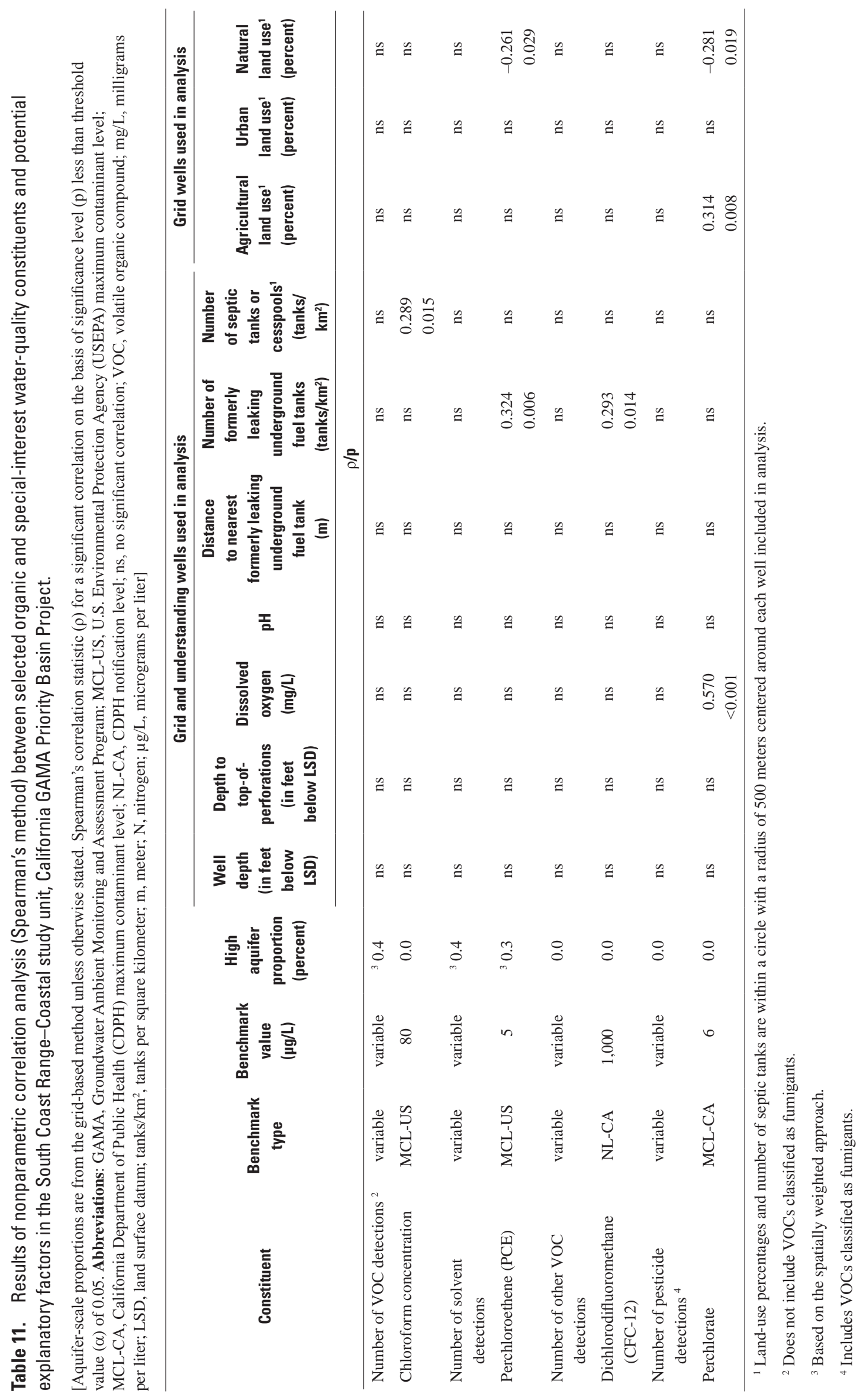


The number of solvents detected and PCE concentrations were higher in modern groundwater than in pre-modern groundwater (table 5). PCE was not correlated with urban land use, although, nationally, solvent concentrations have been correlated with urban land use because most solvents are of anthropogenic origin (Zogorski and others, 2006; Moran and others, 2007). However, PCE was negatively correlated with natural land use and positively correlated to the number of LUFTs per square kilometer within $500 \mathrm{~m}$ of the sampled wells (table 11). Because LUFTs are correlated to urban land use, these correlations may relate to the anthropogenic sources of PCE.

\section{Dichlorodifluoromethane (CFC-12) and Other Volatile Organic Compounds}

The organic constituent class referred to as "other VOCs" includes organic synthesis reagents, refrigerants, and gasoline hydrocarbons. Other VOCs, as a class, were not detected at high or moderate relative-concentrations in the primary aquifer system in the SCRC study unit (table 9). Detections of other VOCs in USGS-grid wells in the SCRC study unit consisted of two refrigerants, one gasoline hydrocarbon, and one gasoline oxygenate (Mathany and others, 2010). Dichlorodifluoromethane (CFC-12), a refrigerant, was detected at low relative-concentrations, with a detection frequency of 11 percent (igs. 18 and $\underline{19}$; Mathany and others, 2010). The distribution of the detections of other VOCs was similar to the distribution of PCE. Most of the detections were near the city of Santa Maria (fig. 20D). CFC-12 concentrations were higher in modern groundwater than in pre-modern groundwater (table 5). CFC-12 concentrations also were correlated to the number of LUFTs per square kilometer within $500 \mathrm{~m}$ of a well (table 11). The correlation of CFC-12 to LUFTs may relate to the anthropogenic origin of CFC-12, or the relation may be coincidence and not have any causative basis.

\section{Pesticides}

Pesticides include herbicides, insecticides, and fungicides and are used in agricultural and urban settings. Pesticides, as a class, were not detected at high or moderate relativeconcentrations in the SCRC study unit (table 9). Pesticides were detected at low relative-concentrations and in less than 10 percent of the primary aquifer system in the SCRC study unit. More than one pesticide (or pesticide degradate) was detected in about half of the wells (9 of 21 wells) with pesticide detections (fig. 20E). The number of pesticide detections was greater in wells with modern groundwater than in wells with pre-modern groundwater (table 5; fig. 21). The number of pesticide detections was not correlated with any of the other explanatory factors evaluated in this report (table 11); however, most of the pesticide detections were in wells less than $400 \mathrm{ft}$ deep (ig. 21). Atrazine and its degradate, deethylatrazine (which does not have a benchmark), were the most frequently detected pesticides at 9 and 18 percent, respectively (Mathany and others, 2010).

\section{Constituents of Special Interest}

Special-interest constituents, similar to organic constituents, usually are anthropogenic in origin. The special-interest constituents analyzed by the Priority Basin Project in the SCRC study unit are perchlorate and $\mathrm{N}$-nitrosodimethylamine (NDMA). Constituents of special interest, as a class, were not detected at high relativeconcentrations in the SCRC study unit, but were detected at moderate relative-concentrations in 29 percent of the primary aquifer system in the SCRC study unit (table 9). Perchlorate was the only constituent of special interest that was detected.

\section{Perchlorate}

Possible anthropogenic sources of perchlorate include nitrate fertilizers mined from the Atacama Desert of Chile that have been used historically on some orchard crops (Dasgupta and others, 2006), or industrial, manufacturing, and commercial uses such as explosives, road flares, rocket fuel, and other products (California Department of Public Health, 2008b; Parker and others, 2008). Perchlorate can occur under natural conditions in a variety of climatic conditions (Fram and Belitz, 2011) and not just in arid climates (Dasgupta and others, 2005; Plummer and others, 2006). However, perchlorate is more likely to occur naturally in the arid and semi-arid environments found further inland in the southwestern United States (Fram and Belitz, 2011). Perchlorate has been detected recently in, or is considered to have the potential to reach, water resources used for drinkingwater supplies (California Department of Public Health, 2008b).

Perchlorate had a detection frequency of 60 percent in the SCRC study unit (fig. 18). Moderate relative-concentrations of perchlorate were located throughout most of the study unit (fig. 22), except from the area north of Santa Maria to Morro Bay in the northern part of the study unit where perchlorate, if detected, had low relative-concentrations. Perchlorate concentrations were generally higher in the Basins study area than in the Uplands study area (table 5).

Perchlorate was positively correlated with DO in the SCRC study unit (table 11; fig. 23). Most of the detections of perchlorate had a DO concentration greater than $2 \mathrm{mg} / \mathrm{L}$. The positive correlation of perchlorate with DO in the SCRC study unit was similar to relations noted in the Central Valley (Landon and others, 2010; Burton and others, 2012). The positive correlation between perchlorate and DO concentration suggests that perchlorate is preserved (or stable) under aerobic conditions because perchlorate can biodegrade under anoxic conditions (Sturchio and others, 2007). 


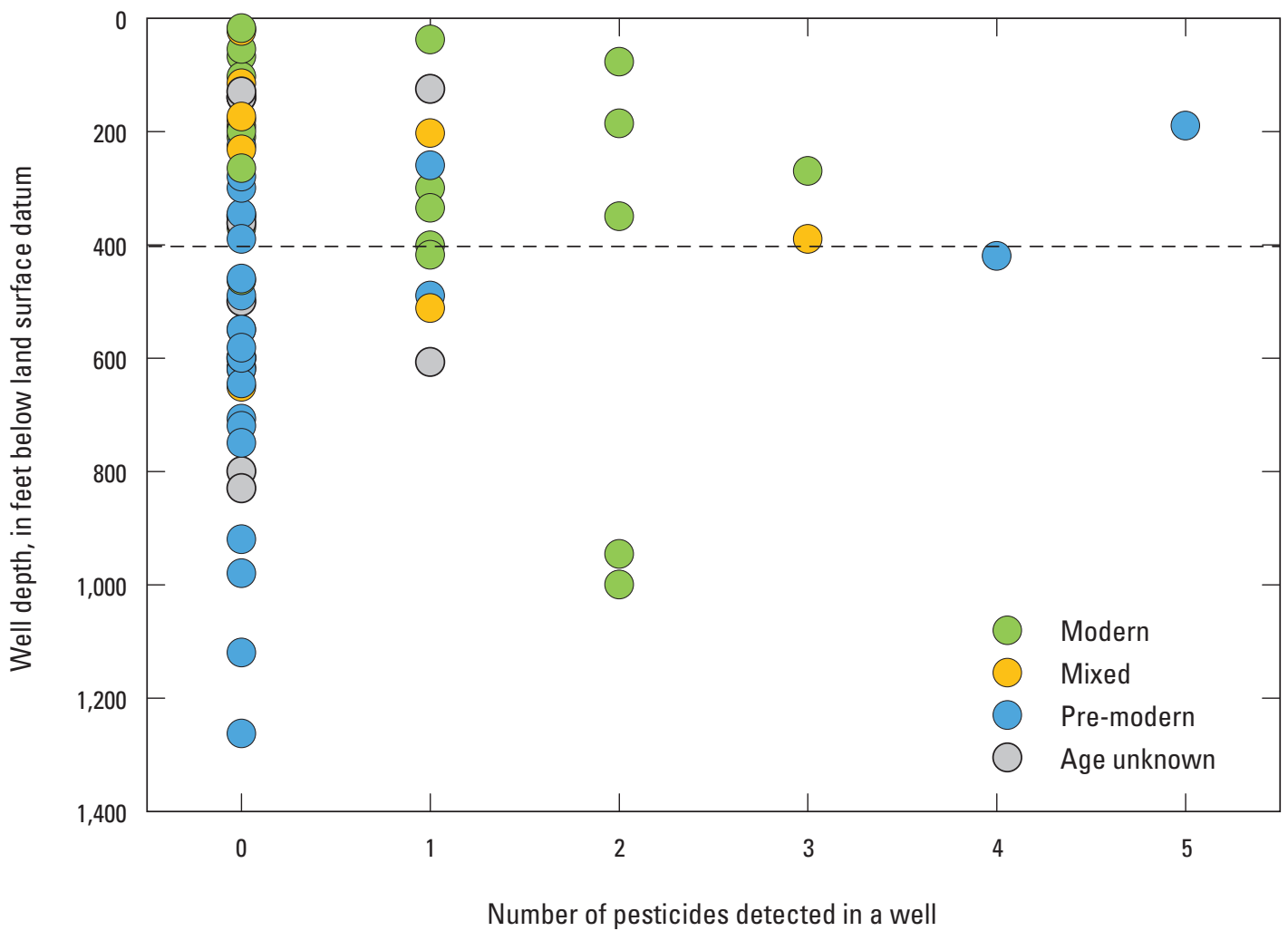

Figure 21. Relation of the number of pesticide detections per well with well depth and groundwater age in the South Coast Range-Coastal study unit, California GAMA Priority Basin Project.

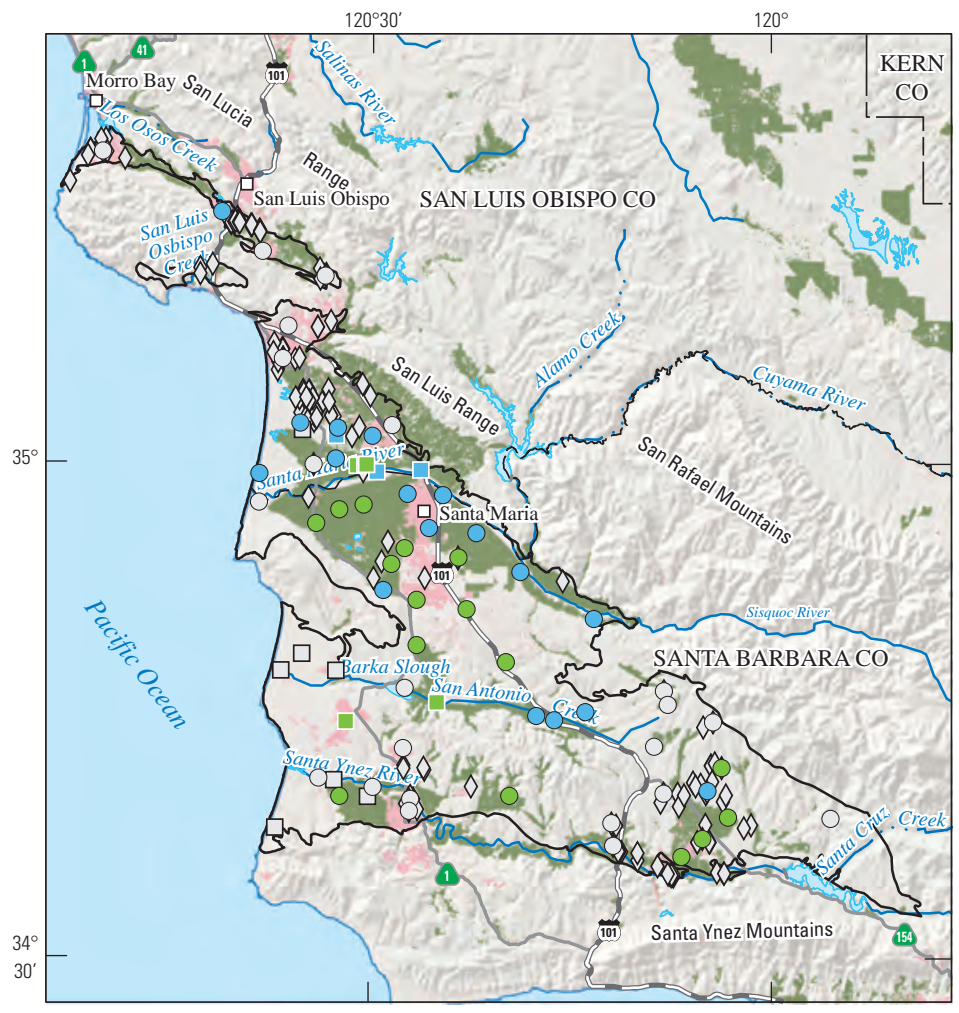

EXPLANATION

Study unit boundary רת

Relative-concentration

Low

Moderate

Low

Moderate
Land-use classification

Urban

Agricultural

Natural

Perchlorate concentration, in micrograms per liter

USGS-grid wells

No detections

$0 \leq 0.6$

$>0.6$ to 6

USGS-understanding wells

$\square$ No detections

$\leq 0.6$

$>0.6$ to 6

CDPH wells

$\diamond$ Not detected

Shaded relief derived from U.S. Geological Survey National Elevation Dataset, 2006 Albers Equal Area Conic Projection

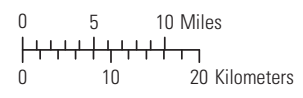

Figure 22. Perchlorate concentrations in USGS-grid wells, USGS-understanding wells, and CDPH-wells in the South Coast Range-Coastal study unit, California GAMA Priority Basin Project. 


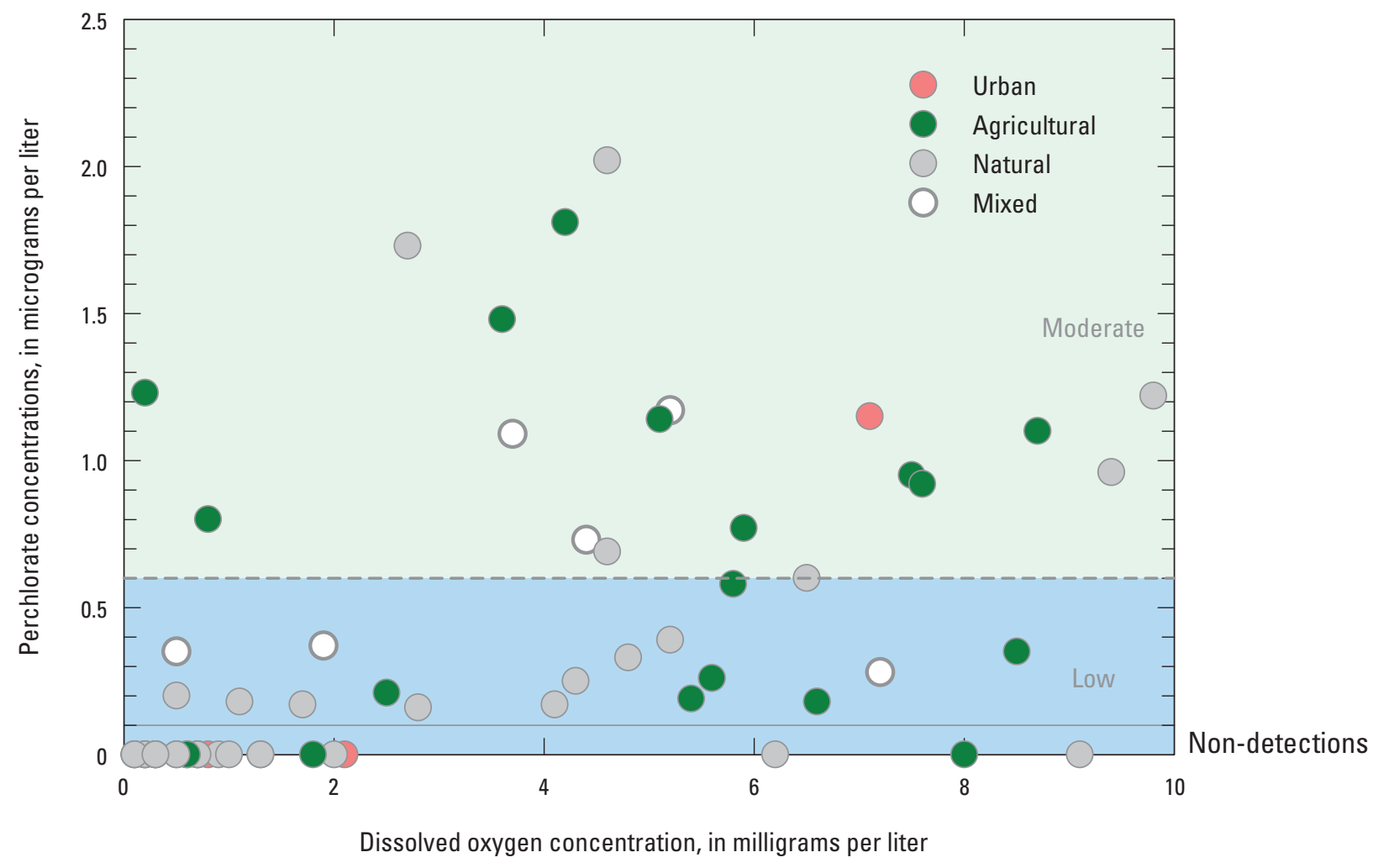

Figure 23. Relation of perchlorate concentrations to dissolved oxygen concentrations in the South Coast RangeCoastal study unit, California GAMA Priority Basin Project.

Perchlorate was correlated to land use (tables 5 and $\underline{11})$. Perchlorate was positively correlated with agricultural land use and negatively correlated with natural land use. Most of the samples collected from agricultural areas (15 of 18) had detections of perchlorate (fig. 23). About half of the samples collected from natural areas (18 of 34) did not have any perchlorate detections.

The predicted probability of detecting naturally occurring perchlorate at a concentration greater than $0.5 \mu \mathrm{g} / \mathrm{L}$ is 5 to 10 percent on the basis of the logistic regression model developed by Fram and Belitz (2011) for the semi-arid climate of the SCRC study unit. This low probability implies that anthropogenic sources may have contributed perchlorate to groundwater in the study unit. The predicted probability of detecting naturally occurring perchlorate at a concentration greater than $0.1 \mu \mathrm{g} / \mathrm{L}$ is 50 to 60 percent (Fram and Belitz, 2011). About half of the detections in the SCRC study unit that are less than $0.5 \mu \mathrm{g} / \mathrm{L}$ are in areas with natural land use. It is possible that some of the detections between 0.1 and $0.5 \mu \mathrm{g} / \mathrm{L}$ are from natural sources.

In summary, perchlorate concentrations were greater in areas with agricultural land use. Perchlorate occurs naturally in the SCRC study unit, but human activities may elevate the perchlorate concentrations. Correlation of perchlorate with DO indicates that biodegradation under anoxic conditions may occur.

\section{Summary}

Groundwater quality in the $766-\mathrm{mi}^{2}\left(1,980-\mathrm{km}^{2}\right)$ South Coast Range-Coastal (SCRC) study unit was investigated as part of the Priority Basin Project of the Groundwater Ambient Monitoring and Assessment (GAMA) Program. The GAMA Priority Basin Project is designed to provide a statistically unbiased, spatially distributed assessment of untreated groundwater quality in the primary aquifer system at the basin-scale. The primary aquifer system was defined as that part of the aquifer corresponding to the perforation interval of wells listed in the California Department of Public Health (CDPH) database for the SCRC study unit.

Wells were randomly selected within spatially distributed grid cells across the study unit to assess the quality of the groundwater. Samples were collected by the U.S. Geological Survey (USGS) from May through November 2008 from 55 grid wells. An additional 15 wells were sampled to improve the understanding of the relation of water quality to explanatory factors representing general groundwater characteristics and land-use activities. Samples from USGSgrid and USGS-understanding wells were analyzed for up to 302 constituents. CDPH inorganic data from the 3-year period (May 20, 2005, to May 19, 2008) were used to complement USGS-grid well data and provide additional information about groundwater quality. 
The first component of this study, the status assessment, characterized the current quality of groundwater resources in the primary aquifer system of the SCRC study unit, before it is treated and delivered to consumers by water purveyors. This assessment used data from samples analyzed for anthropogenic constituents such as volatile organic compounds (VOCs) and pesticides, as well as naturally occurring inorganic constituents such as major ions and trace elements. Relative-concentrations (sample concentration divided by the health- or aesthetic-based benchmark concentration) were used for evaluating groundwater quality for those constituents that have Federal and (or) California regulatory or non-regulatory benchmarks for drinking-water quality. The relative-concentration threshold for classifying inorganic constituents as moderate was 0.5 , whereas for organic constituents it was 0.1 . A relative-concentration of 0.1 was used as a boundary between low and moderate values of organic and special-interest constituents for consistency with other studies and reporting requirements.

Aquifer-scale proportion was used as a metric for assessing the quality of untreated groundwater within the SCRC study unit. High aquifer-scale proportion is defined as the areal percentage of the primary aquifer system with a relative-concentration greater than 1.0 for a particular constituent or class of constituents. Moderate and low aquiferscale proportions were defined as the areal percentage of the primary aquifer system with moderate and low relativeconcentrations, respectively. Grid-based and spatially weighted statistical approaches were used to assess aquiferscale proportions of constituents at high, moderate, and low relative-concentrations in the primary aquifer system.

Inorganic constituents were more prevalent and generally had higher relative-concentrations than organic constituents. For inorganic constituents with human-health benchmarks, relative-concentrations for 33 percent of the primary aquifer system were high for at least one constituent in the SCRC study unit. The inorganic constituents with human-healthbased benchmarks that were detected at high relativeconcentrations in more than 2 percent of the primary aquifer system were arsenic, molybdenum, and nitrate.

For inorganic constituents with aesthetic benchmarks (SMCLs), relative-concentrations were high for at least one constituent in 35 percent of the primary aquifer system in the SCRC study unit. Inorganic constituents with aesthetic benchmarks that were detected at high relative-concentrations in more than 2 percent of the primary aquifer system were iron, manganese, total dissolved solids (TDS), and sulfate.

In contrast to inorganic constituents, organic constituents with human-health benchmarks were not detected at high relative-concentrations in the primary aquifer system in the SCRC study unit. Of the 85 VOCs analyzed, 9 were detected-8 with human-health benchmarks. Perchloroethene (PCE) was the only VOC detected at moderate relative-concentrations in the SCRC study unit. PCE, dichlorodifluoromethane (CFC-12), and chloroform had detection frequencies greater than 10 percent. Of the 120 pesticides and degradates analyzed, 12 were detected -5 with human-health benchmarks. All pesticides were detected at low relative-concentrations or were not detected. The special-interest constituent perchlorate was detected at moderate relative-concentrations in 29 percent of the primary aquifer system and had a detection frequency of 60 percent in the SCRC study unit.

The second component of this work, the understanding assessment, identified some of the primary natural and human factors that may affect groundwater quality by evaluating correlations between potential explanatory factors and relative-concentrations of constituents. The potential explanatory factors evaluated were land use, well depth, septic system density, density and distance to nearest formerly leaking underground fuel tanks (LUFTs), groundwater age, and geochemical conditions (dissolved oxygen [DO] and $\mathrm{pH}$ ). Results from these analyses attempt to explain the occurrence and distribution of constituents in the SCRC study unit.

Selected constituents with high relative-concentrations for any constituent or detection frequencies greater than or equal to 10 percent for organic constituents were selected to focus the understanding assessment on those constituents that were of greatest concern.

Arsenic concentrations were higher in pre-modern and mixed-age groundwater than in modern groundwater. In the Basins study area, data indicate that the occurrences of elevated arsenic concentrations likely result from the release of naturally occurring arsenic from dissolution of aquifer sediments under reducing conditions. In the Uplands study area, arsenic concentrations may be elevated as a result of extended exposure to arsenic-bearing minerals or arsenic adsorbed to minerals in the aquifer sediments in areas where $\mathrm{DO}$ is relatively low.

Molybdenum was negatively correlated with urban land use and positively correlated with well depth, the distance to the nearest LUFT, and arsenic concentrations. These correlations indicate that molybdenum is from natural sources. Molybdenum showed similar geochemical characteristics to arsenic; molybdenum concentrations may be influenced by the release of adsorbed molybdenum during reductive dissolution of metal oxides. In other areas, molybdenum concentrations may be influenced by $\mathrm{pH}$-dependent desorption from aquifer sediments under oxic conditions.

Nitrate was positively correlated to agricultural land use and negatively correlated to natural land use. Nitrate concentrations are higher in modern groundwater than in mixed-age or pre-modern groundwater. The correlations with groundwater age and land use are consistent with elevated concentrations of nitrate resulting from human activities. Nitrate was positively correlated with DO and negatively correlated with manganese and iron concentrations, which indicates that nitrate may be influenced by redox conditions in the SCRC study unit.

Manganese and iron were negatively correlated to DO and $\mathrm{pH}$, and concentrations were higher in older groundwater. Manganese and iron concentrations were not correlated to 
any other explanatory factor. These correlations indicate that manganese and iron are from naturally occurring sediments and that concentrations likely are influenced by the reductive dissolution of manganese and iron oxides in reducing environments.

TDS and sulfate are naturally occurring as a result of interaction of the groundwater with the sediments that exist in the SCRC study unit. TDS and sulfate concentrations were higher in the Basins study area than in the Uplands study area. Higher concentrations of TDS also were in modern groundwater and areas with agricultural or urban land use. TDS concentrations decrease with well depth. Sulfate concentrations were higher in modern groundwater and in areas with agricultural land use. These correlations indicate that human activities elevate natural TDS and sulfate concentrations.

Organic compounds usually were detected at low relative-concentrations; therefore, statistical analyses of relations to explanatory factors usually were done for classes of constituents. Classes of organic compounds consisted of VOCs - which were further subdivided into trihalomethanes (THMs), solvents, and other VOCs—and pesticides. The number of VOCs detected in any particular well was not correlated to any of the explanatory factors evaluated.

The number of solvents and pesticides detected in a well, PCE concentrations, and CFC-12 concentrations were higher in modern groundwater than in pre-modern groundwater. PCE and CFC-12 were also correlated to the number of LUFTs located near the well; PCE was negatively correlated to natural land use. These VOC compounds appear to be more prevalent in urban areas than in agricultural or natural areas in the study unit.

Perchlorate was positively correlated with agricultural land use and DO and negatively correlated with natural land use. Perchlorate concentrations were greater in agricultural areas than in urban areas. Correlation of perchlorate with DO indicates that perchlorate is more stable under aerobic conditions. Perchlorate concentrations generally were high in groundwater with high DO concentrations. Anthropogenic sources have contributed perchlorate to groundwater in the SCRC study unit, although low levels of perchlorate may occur naturally.

Low-level analyses of VOCs and pesticides may be used as tracers of groundwater that has recharged over the decades when these compounds began to be used for industrial and commercial purposes. Low-level analyses provide an early awareness of constituents whose presence in groundwater at low concentrations may be important for the prioritization of monitoring water quality in the future.

\section{Acknowledgments}

The authors thank the following cooperators for their support: the California State Water Resources Control Board, Lawrence Livermore National Laboratory, California Department of Public Health, and California Department of Water Resources. We especially thank the well owners and water purveyors for their cooperation and generosity in allowing the USGS to collect samples from their wells. Funding for this work was provided by State of California bonds authorized by Proposition 50 and administered by the State Water Resources Control Board.

\section{References Cited}

Andrews, J.N., 1985, The isotopic composition of radiogenic helium and its use to study groundwater movement in confined aquifers: Chemical Geology, v. 49, p. 339-351.

Andrews, J.N., and Lee, D.J., 1979, Inert gases in groundwater from the Bunter Sandstone of England as indicators of age and paleoclimatic trends: Journal of Hydrology, v. 41, p. 233-252.

Arndt, M.F., 2010, Evaluation of gross alpha and uranium measurements for MCL compliance: Denver, CO, Water Research Foundation, 299 p.

Belitz, Kenneth, Dubrovsky, N.M., Burow, K.R., Jurgens, Bryant, and Johnson, Tyler, 2003, Framework for a ground-water quality monitoring and assessment program for California: U.S. Geological Survey Water-Resources Investigations Report 03-4166, 78 p. (Also available at http://pubs.usgs.gov/wri/wri034166/.)

Belitz, K., Jurgens, B., Landon, M.K., Fram, M.S., and Johnson, T., 2010, Estimation of aquifer-scale proportion using equal-area grids-Assessment of regional-scale groundwater quality: Water Resources Research, v. 46, citation number W11550, doi:10.1029/2010WR009321, accessed March 14, 2011, at http://www.agu.org/pubs/ crossref/2010/2010WR009321.shtml.

Belzile, Nelson, and Lebel, Jean, 1986, Capture of arsenic by pyrite in near-shore marine sediments: Chemical Geology, v. 54, p. 279-281. 
Bennett, G.L., V, Fram, M.S., Belitz, Kenneth, and Jurgens, B.C., 2010, Status and understanding of groundwater quality in the northern San Joaquin Basin, 2005: California GAMA Priority Basin Project: U.S. Geological Survey Scientific Investigations Report 2010-5175, 82 p.

Bright, D.J., Nash, D.B., and Martin, Peter, 1997, Evaluation of the ground-water flow and solute transport in the Lompoc area, Santa Barbara County, California: U.S. Geological Survey Water-Resources Investigations Report 97-4056, $113 \mathrm{p}$.

Bright, D.J., Stamos, C.L., Martin, P., and Nash, D.B., 1992, Ground-water hydrology and quality in the Lompoc area, Santa Barbara County, California, 1987-88: U.S. Geological Survey Water-Resources Investigations Report 91-4172, 77 p.

Brown, L.D., Cai, T.T., and Dasgupta, A., 2001, Interval estimation for a binomial proportion: Statistical Science, v. 16, no. 2, p. 101-133, doi:10.1214/ss/1009213286, accessed March 14, 2011, at http://projecteuclid.org/euclid. ss/1009213286.

Burton, C.A., Montrella, Joseph, Landon, M.K., and Belitz, Kenneth, 2011, Status and understanding of groundwater quality in the Santa Clara River Valley, 2007California GAMA Priority Basin Project: U.S. Geological Survey Scientific Investigations Report 2011-5052, 86 p.

Burton, C.A., Shelton, J.L., and Belitz, Kenneth, 2012, Status and understanding of groundwater quality in the two southern San Joaquin Valley study units, 2005-2006California GAMA Priority Basin Project: U.S. Geological Survey Scientific Investigations Report 2011-5218, 150 p. (Also available at http://pubs.usgs.gov/sir/2011/5218/.)

California Department of Health Services, 2007, California Code of Regulations, Title 22, Social Security, Division 4, Environmental Health, Chapter 15, Domestic water quality and monitoring regulations: Register 2007, No. 4, accessed February 10, 2007, at http://ccr.oal.ca.gov/.

California Department of Pesticide Regulation, 2008, California pesticide information portal, accessed April 2, 2008, at http://calpip.cdpr.ca.gov/main.cfm.

California Department of Public Health, 2008a, California drinking water-related laws: California Department of Public Health website, accessed June 1, 2008, at http:// www.cdph.ca.gov/certlic/drinkingwater/Pages/Lawbook. aspx.

California Department of Public Health, 2008b, Perchlorate in drinking water: California Department of Public Health website, accessed January 2, 2008 at http://www.cdph. ca.gov/certlic/drinkingwater/Pages/Perchlorate.aspx.
California Department of Public Health, 2012, California Code of Regulation, Title 22, Division 4, Environmental Health, Chapter 15, Domestic water quality and monitoring regulations, accessed March 20, 2012, at http://ccr.oal. ca.gov.

California Department of Water Resources, 2002, Water resources of the Arroyo Grande - Nipomo Mesa, 2002: Southern District report, 160 p. accessed October 5, 2011, at http://wwwdpla.water.ca.gov/sd/water quality/arroyo grande/arroyo_grande-nipomo_mesa.html.

California Department of Water Resources, 2003, California's groundwater: California Department of Water Resources Bulletin 118, 246 p., accessed March 23, 2011, at http:/www.water.ca.gov/groundwater/bulletin118/ bulletin118update2003.cfm.

California Department of Water Resources, 2004a, California's groundwater, Los Osos Valley Groundwater Basin: California Department of Water Resources Bulletin 118, accessed September 14, 2009, at http://www.water.ca.gov/ pubs/groundwater/bulletin 118/basindescriptions/3-8.pdf.

California Department of Water Resources, 2004b, California’s groundwater, San Luis Obispo Valley Groundwater Basin: California Department of Water Resources Bulletin 118, accessed September 14, 2009, at http://www.water.ca.gov/pubs/groundwater/bulletin 118/ basindescriptions/3-9.pdf.

California Department of Water Resources, 2004c, California's groundwater, Santa Maria River Valley Groundwater Basin: California Department of Water Resources Bulletin 118, accessed September 14, 2009, at http://www.water.ca.gov/ pubs/groundwater/bulletin_118/basindescriptions/3-12.pdf.

California Department of Water Resources, 2004d, California's groundwater, San Antonio Creek Valley Groundwater Basin: California Department of Water Resources Bulletin 118, accessed September 14, 2009, at http://www.water.ca.gov/pubs/groundwater/bulletin 118/ basindescriptions/3-14.pdf.

California Department of Water Resources, 2004e, California's groundwater, Santa Ynez River Valley Groundwater Basin: California Department of Water Resources Bulletin 118, accessed September 14, 2009, at http://www.water.ca.gov/ pubs/groundwater/bulletin_118/basindescriptions/3-15.pdf.

California Environmental Protection Agency, 2001, Geographic Environmental Information Management System GeoTracker (GEIMS) Leaking Underground Fuel/ Storage Tank database (LUFT) [digital data]: Sacramento, Calif., California Environmental Protection Agency, State Water Resources Control Board, Division of Water Quality. 
California State Water Resources Control Board, 2003, A Comprehensive Groundwater Quality Monitoring Program for California: Report to the Governor and Legislature, March 2003, 121 p., accessed March 28, 2011, at http://www.waterboards.ca.gov/gama/docs/final_ab 599 rpt to legis 731 03.pdf.

California State Water Resources Control Board, 2011, GAMA — Groundwater Ambient Monitoring and Assessment Program: State Water Resources Control Board website, accessed March 14, 2011, at http://www. waterboards.ca.gov/water issues/programs/gama.

Chapelle, F.H., 2001, Ground-water microbiology and geochemistry: New York, John Wiley and Sons, Inc., 477 p.

Chapelle, F.H., McMahon, P.B., Dubrovsky, N.M., Fuji, R.F., Oaksford, E.T., and Vroblesky, D.A., 1995, Deducing the distribution of terminal electron-accepting processes in hydrologically diverse groundwater systems: Water Resources Research, v. 31, no. 2, p. 359-371.

Clark, I.D., and Fritz, P., 1997, Environmental isotopes in hydrogeology: Boca Raton, Florida, CRC Press LLC, 328 p.

Cook, P.G., and Böhlke, J.K., 2000, Determining timescales for groundwater flow and solute transport, in Cook, P.G., and Herczeg, A., eds., Environmental tracers in subsurface hydrology: Boston, Kluwer Academic Publishers, p. 1-30.

Coplen, T.B., 2011, Guidelines and recommended terms for expression of stable-isotope-ratio and gas-ratio measurement results: Rapid Communications in Mass Spectrometry, v. 25, p. 2538-2560.

Craig, H., and Lal, D., 1961, The production rate of natural tritium: Tellus, v. 13, p. 85-105.

Dasgupta, P.K., Dyke, J.V., Kirk, A.B., and Jackson, W.A., 2006, Perchlorate in the United States-Analysis of relative source contributions to the food chain: Environmental Science \& Technology, v. 40, p. 6608-6614, doi: 10.1021/ es061321z, accessed March 14, 2011, at http://pubs.acs.org/ doi/abs/10.1021/es061321z.

Dasgupta, P.K., Martinelango, P.K., Jackson, W.A., Anderson, T.A., Tian, K., Tock, R.W., and Rajagopalan, S., 2005, The origin of naturally occurring perchlorate-The role of atmospheric processes: Environmental Science \& Technology, v. 39, p. 1569-1575.

Davis, S., and DeWiest, R.J., 1966, Hydrogeology: New York, John Wiley and Sons, 413 p.

Drever, J.I., 1997, The geochemistry of natural waterSurface and groundwater environments ( $3^{\mathrm{d}}$ ed.): Upper Saddle River, New Jersey, Prentice Hall, 436 p.
Eaton, G.F., Hudson, G.B., and Moran, J.E., 2003, Tritiumhelium-3 age-dating of groundwater in the Livermore Valley of California: American Chemical Society ACS Symposium Series, v. 868, p. 235-245.

Fontes, J.C., and Garnier, J.M., 1979, Determination of the initial ${ }^{14} \mathrm{C}$ activity of the total dissolved carbon-A review of the existing models and a new approach: Water Resources Research, v. 15, p. 399-413.

Fram, M.S., and Belitz, K., 2011, Probability of detecting perchlorate under natural conditions in deep groundwater in California and the southwestern United States: Environmental Science \& Technology, v. 45, p. 1271-1277.

Fram, M.S., and Belitz, K., 2012, Status and understanding of groundwater quality in the Tahoe-Martis, Central Sierra, and Southern Sierra study units, 2006-2007-California GAMA Priority Basin Project: U.S. Geological Survey Scientific Investigations Report 2011-5216, 222 p.

Gilliom, R.J., Barbash, J.E., Crawford, C.G., Hamilton, P.A., Martin, J.D., Nakagaki, N., Nowell, L.H., Scott, J.C., Stackelberg, P.E., Thelin, G.P., and Wolock, D.M., 2006, The quality of our Nation's waters-Pesticides in the Nation's streams and ground water, 1992-2001: U.S. Geological Survey Circular 1291, 172 p. (Also available at http://pubs.usgs.gov/circ/2005/1291/.)

Goldberg, Sabine, 2009, Influence of soil solution salinity on molybdenum adsorption by soils: Soil Science, v. 174, p. 9-13.

Green, C.T., Puckett, L.J., Böhlke, J.K., Bekins, B.A., Phillips, S.P., Kauffman, L.J., Denver, J.M., and Johnson, H.M., 2008, Limited occurrence of denitrification in four shallow aquifers in agricultural areas of the United States: Journal of Environmental Quality, v. 37, p. 9941009.

Hamlin, S.N., 1985, Ground-water quality in the Santa Rita, Buellton, and Los Olivos hydrologic subareas of the Santa Ynez River basin, Santa Barbara County, California: U.S. Geological Survey Water-Resources Investigations Report 84-4131, 75 p.

Helsel, D.R., and Hirsch, R.M., 2002, Statistical methods in water resources: U.S. Geological Survey Techniques of Water-Resources Investigations, book 4, chapter A3, 510 p. (Also available at http://water.usgs.gov/pubs/twri/twri4a3/.)

Hem, J.D., 1970, Study and interpretation of the chemical characteristics of natural water (2d ed.): U.S. Geological Survey Water-Supply Paper 1473, 363 p.

Hem, J.D., 1985, Study and interpretation of the chemical characteristics of natural water (3d ed.): U.S. Geological Survey Water-Supply Paper 2254, 263 p. 
Hutson, S.S., Barber, N.L., Kenny, J.F., Linsey, K.S., Lumia, D.S., and Maupin, M.A., 2004, Estimated use of water in the United States in 2000: U.S. Geological Survey Circular 1268, 46 p. (Also available at http://pubs.usgs.gov/ circ/2004/circ1268/index.html.)

Isaaks, E.H., and Srivastava, R.M., 1989, Applied geostatistics: New York, Oxford University Press, 561 p.

Izbicki, J.A., Stamos, C.L., Metzger, L.F., Halford, K.J., Kulp, T.R., and Bennett, G.L., 2008, Source, distribution, and management of arsenic in water from wells, eastern San Joaquin ground-water subbasin, California: U.S. Geological Survey Open-File Report 2008-1272, 8 p. (Also available at http://pubs.usgs.gov/of/2008/1272/.)

Jennings, C.W., 1977, Geologic map of California: California Department of Conservation, Division of Mines and Geology, Geologic Data Map, No. 2, scale 1:750,000.

Johnson, T.D., and Belitz, K., 2009, Assigning land use to supply wells for the statistical characterization of regional groundwater quality —Correlating urban land use and VOC occurrence: Journal of Hydrology, v. 370, p. 100-108.

Jurgens, B.C., McMahon, P.B., Chapelle, F.H., and Eberts, S.M., 2009, An Excel ${ }^{\circledR}$ workbook for identifying redox processes in ground water: U.S. Geological Survey Open-File Report 2009-1004, 8 p. (Also available at http:// pubs.usgs.gov/of/2009/1004/.)

Kendall, C., 1998, Tracing nitrogen sources and cycling in catchments, in Kendall, C., and McDonnell, J.J., eds., Isotope tracers in catchment hydrology: Amsterdam, Elsevier Science, chapter 16, p. 519-576.

Kulongoski, J., and Belitz, K., 2004, Ground-Water Ambient Monitoring and Assessment Program: U.S. Geological Survey Fact Sheet 2004-3088, 2 p.

Kulongoski, J.T., and Belitz, Kenneth, 2011, Status and understanding of groundwater quality in the Monterey Bay and Salinas Valley Basins, 2005-California GAMA Priority Basin Project: U.S. Geological Survey Scientific Investigations Report 2011-5058, 84 p.

Kulongoski, J.T., Belitz, Kenneth, Landon, M.K., and Farrar, Christopher, 2010, Status and understanding of groundwater quality in the North San Francisco Bay groundwater basins, 2004_California GAMA Priority Basin Project: U.S. Geological Survey Scientific Investigations Report 2010-5089, 88 p.

Kulongoski, J.T., Hilton, D.R., Cresswell, R.G., Hostetler, S., and Jacobson, G., 2008, Helium-4 characteristics of groundwaters from Central Australia-Comparative chronology with chlorine-36 and carbon-14 dating techniques: Journal of Hydrology, v. 348, p. 176-194.
Landon, M.K., Belitz, K., Jurgens, B.C., Kulongoski, J.T., and Johnson, T.D., 2010, Status and understanding of groundwater quality in the Central Eastside San Joaquin Basin, 2006-California GAMA Program Priority Basin Project: U.S. Geological Survey Scientific Investigations Report 2009-5266, 97 p. (Also available at http://pubs.usgs. gov/sir/2009/5266/.)

Lindburg, R.D., and Runnells, D.D., 1984, Groundwater redox reactions: Science, v. 225, p. 925-927.

Lucas, L.L., and Unterweger, M.P., 2000, Comprehensive review and critical evaluation of the half-life of tritium: Journal of Research of the National Institute of Standards and Technology, v. 105, no. 4, p. 541-549.

Maher, W.A., 1984, Mode of occurrence and speciation of arsenic in some pelagic and estuarine sediments: Chemical Geology, v. 47, p. 333-345.

Manning, A.H., Solomon, D.K., and Thiros, S.A., 2005, ${ }^{3} \mathrm{H} /{ }^{3} \mathrm{He}$ age data in assessing the susceptibility of wells to contamination: Ground Water, v. 43, no. 3, p. 353-367.

Mathany, T.M., Burton, C.A., Land, Michael, and Belitz, Kenneth, 2010, Groundwater-quality data in the South Coast Range-Coastal study unit, 2008-Results from the California GAMA Program: U.S. Geological Survey Data Series 504, 106 p.

McMahon, P.B., and Chapelle, F.H., 2008, Redox processes and water quality of selected principal aquifer systems: Ground Water, v. 46, no. 2, p. 259-271.

Michel, R.L., 1989, Tritium deposition in the continental United States, 1953-83: U.S. Geological Survey WaterResources Investigations Report 89-4072, 46 p.

Michel, R.L., and Schroeder, R., 1994, Use of long-term tritium records from the Colorado River to determine timescales for hydrologic processes associated with irrigation in the Imperial Valley, California: Applied Geochemistry, v. 9, p. 387-401.

Mook, W.G., and Van Der Plicht, Johannes, 1999, Reporting ${ }^{14} \mathrm{C}$ activities and concentrations: Radiocarbon, v. 41, no. 3 , p. 227-239.

Moran, J.E., Hudson, G.B., Eaton, G.F., and Leif, R., 2002, A contamination vulnerability assessment for the Livermore-Amador and Niles Cone Groundwater Basins: Lawrence Livermore National Laboratory internal report UCRL-AR-148831, 25 p.

Moran, M.J., Zogorski, J.S., and Squillace, P.J., 2007, Chlorinated solvents in groundwater of the United States: Environmental Science \& Technology, v. 41, no. 1, p. 74-81. 
Morrison, P., and Pine, J., 1955, Radiogenic origin of the helium isotopes in rock: Annual New York Academy of Sciences, v. 12, p. 19-92.

Nakagaki, Naomi, Price, C.V., Falcone, J.A., Hitt, K.J., and Ruddy, B.C., 2007, Enhanced National Land Cover Data 1992 (NLCDe 92): U.S. Geological Survey raster digital data, accessed March 28, 2011, at http://water.usgs.gov/ lookup/getspatial?nlcde92.

Nakagaki, Naomi, and Wolock, D.M., 2005, Estimation of agricultural pesticide use in drainage basins using land cover maps and county pesticide data: U.S. Geological Survey Open-File Report 2005-1188, 46 p. (Also available at http://pubs.usgs.gov/of/2005/1188/.)

Parker, D.R., Seyfferth, A.L., and Kiel, B.K., 2008, Perchlorate in groundwater-A synoptic survey of "pristine" sites in the coterminous United States: Environmental Science \& Technology, v. 42, no. 5, p. $1465-1471$.

Paul, A.P., Seiler, R.L., Rowe, T.G., and Rosen, M.R., 2007, Effects of agriculture and urbanization on quality of shallow ground water in the arid to semiarid western United States, 1993-2004: U.S. Geological Survey Scientific Investigations Report 2007-5179, 56 p.

Piper, A.M., 1944, A graphic procedure in the geochemical interpretation of water analyses: American Geophysical Union Transactions, v. 25, p. 914-923.

Plummer, L.N., Bexfield, L.M., Anderholm, S.K., Sanford, W.E., and Busenberg, Eurybiades, 2004, Geochemical characterization of groundwater flow in the Santa Fe Group aquifer system, Middle Rio Grande Basin, New Mexico: U.S. Geological Survey Water-Resources Investigations Report 03-4131, 395 p.

Plummer, L.N., Böhlke, J.K., and Doughten, M.W., 2006, Perchlorate in Pleistocene and Holocene groundwater in North-Central New Mexico: Environmental Science and Technology, v. 40, no. 6, p. 1757-1763.

Plummer, L.N., Michel, R.L., Thurman, E.M., and Glynn, P.D., 1993, Environmental tracers for age-dating young ground water, in Alley, W.M., ed., Regional groundwater quality: New York, Van Nostrand Reinhold, chap. 11, p. 255-294.

Poreda, R.J., Cerling, T.E., and Salomon, D.K., 1988, Tritium and helium isotopes as hydrologic tracers in a shallow unconfined aquifer: Journal of Hydrology, v. 103, p. 1-9.

Reimann, C., and de Caritat, P., 1998, Chemical elements in the environment, factsheets for the geochemist and environmental scientist: Berlin, Springer-Verlag, 398 p.
Reisenauer, H.M., Walsh, L.M., and Hoeft, R.G., 1973, Testing soils for sulphur, boron, molybdenum, and chlorine, in Walsh, L.M., and Beaton, J.D., eds., Soil testing and plant analysis, revised edition: Madison, Wisconsin, Soil Science Society of America, p. 173-200.

Revesz, K., Böhlke, J.K., Smith, R.L., and Yoshinari, T., 1999, Stable isotope composition of dissolved $\mathrm{O}_{2}$ undergoing respiration in a ground-water contamination gradient, in Morganwalp, D.W., and Buxton, H.T., eds., U.S. Geological Survey Toxic Substances Hydrology Program-Proceedings of the Technical Meeting, Charleston, South Carolina, March 8-12, 1999: U.S. Geological Survey WaterResources Investigations Report 99-4018B, p. 323-328.

Rowe, B.L., Toccalino, P.L., Moran, M.J., Zogorski, J.S., and Price, C.V., 2007, Occurrence and potential human-health relevance of volatile organic compounds in drinking water from domestic wells in the United States: Environmental Health Perspectives, v. 115, no. 11, p. 1539-1546.

Russell, H.H., Matthews, J.E., and Sewell, G.W., 1992, TCE removal from contaminated soil and ground water: U.S. Environmental Protection Agency, EPA/540/S-92/002, $10 \mathrm{p}$.

Saucedo, G.J., Bedford, D.R., Raines, G.L., Miller, R.J., and Wentworth, C.M., 2000, GIS data for the geologic map of California (version 2.0): Sacramento, Calif., California Department of Conservation, Division of Mines and Geology.

Schlosser, P., Stute, M., Dörr, H., Sonntag, C., and Munnich, K.O., 1988, Tritium $/{ }^{3}$ He dating of shallow groundwater: Earth and Planetary Science Letters, v. 89, p. 353-362.

Scott, J.C., 1990, Computerized stratified random site selection approaches for design of a ground-water quality sampling network: U.S. Geological Survey Water-Resources Investigations Report 90-4101, 109 p.

Solomon, D.K., and Cook, P.G., 2000, ${ }^{3} \mathrm{H}$ and ${ }^{3} \mathrm{He}$, in Cook, P.G., and Herczeg, A.L., eds., Environmental tracers in subsurface hydrology: Boston, Kluwer Academic Press, p. 397-424.

Sparks, D.L., 2003, Environmental soil chemistry, $2^{\mathrm{d}}$ ed.: San Diego, Academic Press, 352 p.

State of California, 1999, Resources-State Water Resources Control Board, in Supplemental Report of the 1999 Budget Act, 1999-00 Fiscal Year: State of California Legislative Analyst's Office website, Item 3940-001-0001, accessed March 16, 2011, at http://www.lao.ca.gov/1999/99-00 supp_rpt_lang.html\#3940. 
State of California, 2001a, Assembly Bill No. 599, Chapter 522, accessed March 16, 2011, at http://www. swrcb.ca.gov/gama/docs/ab 599 bill 20011005 chaptered. pdf.

State of California, 2001b, Groundwater Monitoring Act of 2001 (California Water Code, pt. 2.76, sec. 1078010782.3), accessed March 16, 2011, at http://www.leginfo. ca.gov/cgi-bin/displaycode?section=wat\&group $=10001-$ $11000 \&$ file $=10780-10782.3$.

Stollenwerk, K.G., 2003, Geochemical processes controlling transport of arsenic in groundwater, a review of adsorption, in Welch, A.H., and Stollenwerk, K.G., eds., Arsenic in groundwater-geochemistry and occurrence: Boston, Kluwer Academic Publishers, 488 p.

Sturchio, N.C., Böhlke, J.K., Beloso, A.D., Streger, S.H., Heraty, L.J., and Hatzinger, P.B., 2007, Oxygen and chlorine isotopic fractionation during perchlorate biodegradationLaboratory results and implications for forensics and natural attenuation studies: Environmental Science \& Technology, v. 41, no. 8 , p. 2796-2802.

Sylvester, A.G., and Darrow, A.C., 1979, Structure and neotectonics of the western Santa Ynez fault system in southern California: Tectonophysics, v. 52, p. 389-405.

Takaoka, N., and Mizutani, Y., 1987, Tritiogenic ${ }^{3} \mathrm{He}$ in groundwater in Takaoka: Earth and Planetary Science Letters, v. 85, p. 74-78.

Tobias, C.R., Böhlke, J.K., and Harvey, J.W., 2007, The oxygen-18 isotope approach for measuring aquatic metabolism in high-productivity waters: Limnology and Oceanography, v. 52, p. 1439-1453, accessed May 21, 2013, at http://aslo.org/lo/toc/vol_52/issue_4/1439.html.

Toccalino, P.L., 2007, Development and application of healthbased screening levels for use in water-quality assessments: U.S. Geological Survey Scientific Investigations Report 2007-5106, 12 p. (Also available at http://pubs.usgs. gov/sir/2007/5106/.)

Toccalino, P.L., and Norman, J.E., 2006, Health-based screening levels to evaluate U.S. Geological Survey ground water quality data: Risk Analysis, v. 26, no. 5, p. 13391348.

Toccalino, P.L., Norman, J.E., Phillips, R.H., Kauffman, L.J., Stackelberg, P.E., Nowell, L.H., Krietzman, S.J., and Post, G.B., 2004, Application of health-based screening levels to ground-water quality data in a state-scale pilot effort: U.S. Geological Survey Scientific Investigations Report 2004-5174, 64 p. (Also available at http://pubs.usgs. gov/sir/2004/5174/.)
Tolstikhin, I.N., and Kamenskiy, I.L., 1969, Determination of groundwater ages by the $\mathrm{T}^{3} \mathrm{He}$ method: Geochemistry International, v. 6, p. 810-811.

Torgersen, T., 1980, Controls on pore-fluid concentrations of ${ }^{4} \mathrm{He}$ and ${ }^{222} \mathrm{Rn}$ and the calculation of ${ }^{4} \mathrm{He} /{ }^{222} \mathrm{Rn}$ ages: Journal of Geochemical Exploration, v. 13, p. 57-75.

Torgersen, T., and Clarke, W.B., 1985, Helium accumulation in groundwater-I. An evaluation of sources and continental flux of crustal ${ }^{4} \mathrm{He}$ in the Great Artesian basin, Australia: Geochimica et Cosmochimica Acta, v. 49, p. 1211-1218.

Upson, J.E., and Thomasson, H.G., 1951, Geology and water resources of the Santa Ynez River Basin, Santa Barbara County, California: U.S. Geological Survey Water-Supply Paper 1107, $194 \mathrm{p}$.

U.S. Census Bureau, 1990, U.S. Census ftp site, accessed September 28, 2010, at ftp://ftp2.census.gov/census 1990.

U.S. Environmental Protection Agency, 1997, Reporting requirements for risk/benefit information; final rule: Federal Register, v. 62, no. 182, Friday, September 19, 1997, Rules and Regulations, p. 49369-49395, accessed March 28, 2011, at http://www.gpoaccess.gov/fr/retrieve.html.

U.S. Environmental Protection Agency, 2000, National primary drinking water regulations; radionuclides; final rule, accessed February 2012 at https://federalregister. gov/a/00-30421.

U.S. Environmental Protection Agency, 2006, 2006 Edition of the Drinking Water Standards and Health Advisories: U.S. Environmental Protection Agency, Office of Water EPA/822/R-06-013, accessed March 16, 2011, at http:// www.epa.gov/waterscience/criteria/drinking/dwstandards. pdf.

U.S. Environmental Protection Agency, 2008a, Drinking water contaminants: U.S. Environmental Protection Agency website, accessed June 1, 2008, at http://www.epa.gov/ safewater/contaminants/index.html.

U.S. Environmental Protection Agency, 2008b, Archived tables, 2006, in Drinking water health advisories and science support-Drinking water standards and health advisory tables: U.S. Environmental Protections Agency website, accessed June 1, 2008, at http://www.epa.gov/ waterscience/criteria/drinking/.

U.S. Environmental Protection Agency, 2009, National primary drinking water regulations, accessed January 2011 at http://water.epa.gov/drink/contaminants/upload/mcl-2. pdf.

U.S. Geological Survey, 2011, What is the Priority Basin Project?: U.S. Geological Survey website, accessed March 16, 2011, at http://ca.water.usgs.gov/gama. 
Valentine, D.W., Densmore, J.N., Galloway, D.L., and Amelung, F., 2001, Use of InSAR to identify land-surface displacements caused by aquifer-system compaction in the Paso Robles area, San Luis Obispo County, California, March to August 1997: U.S. Geological Survey Open-File Report 00-447, 1 p.

Vogel, J.C., and Ehhalt, D., 1963, The use of the carbon isotopes in groundwater studies, in Radioisotopes in Hydrology: Vienna, International Atomic Energy Agency, p. 383-395.

Vogel, T.M., and McCarty, P.L., 1985, Biotransformation of tetrachloroethylene, dichloroethylene, vinyl chloride, and carbon dioxide under methanogenic conditions: Applied and Environmental Microbiology, v. 49, no. 5, p. 1080-1083.

Water Education Foundation, 2006, Where does my water come from?: State Water Resources Control Board website, accessed March 16, 2011, at http://www.water-ed.org/ watersources/default.asp.

Weiss, R.F., 1968, Piggyback sampler for dissolved gas studies on sealed water samples: Deep Sea Research, v. 15, p. 721-735.

Welch, A.H., Oremland, R.S., Davis, J.A., and Watkins, S.A., 2006, Arsenic in groundwater-A review of current knowledge and relation to the CALFED solution area with recommendations for needed research: San Francisco Estuary and Watershed Science, v. 4, no. 2, article 4, 32 p.
Welch, A.H., Westjohn, D.B., Helsel, D.R., and Wanty, R.B., 2000, Arsenic in ground water of the United StatesOccurrence and geochemistry: Ground Water, v. 38, no. 4, p. 589-604.

Wilson, H.D., Jr., 1959, Ground-water appraisal of the Santa Ynez River Basin, Santa Barbara County, California, 1945-52: U.S. Geological Survey Water-Supply Paper 1467, $119 \mathrm{p}$.

Wong, C.T., Okamoto, H.S., Milea, A.M., Perera, S.K., and Baumann, F.J., 1999, Isotopic uranium activity ratios in California groundwater: Journal of the American Water Works Association, v. 91, no.4, p. 171-185.

Worts, G.F., Jr., 1951, Geology and ground-water resources of the Santa Maria Valley area, California: U.S. Geological Survey Water-Supply Paper 1000, 169 p.

Yates, E.B., and Wiese, J.H., 1988, Hydrogeology and water resources of the Los Osos Valley ground-water basin, San Luis Obispo County, California: U.S. Geological Survey Water-Resources Investigations Report 88-4081, 74 p.

Zogorski, J.S., Carter, J.M., Ivahnenko, T., Lapham, W.W., Moran, M.J., Rowe, B.L., Squillace, P.J., and Toccalino, P.L., 2006, The quality of our Nation's watersVolatile organic compounds in the Nation's ground water and drinking-water supply wells: U.S. Geological Survey Circular 1292, 101 p. (Also available at http://pubs.usgs. gov/circ/circ1292/.) 


\section{Appendix A. Selection of California Department of Public Health Grid Wells}

California requires samples to be collected regularly from public-supply wells under Title 22 (California Department of Health Services, 2007). Historical data derived from these samples are available from the CDPH database. Assembly Bill 599 directs the GAMA Program to use available data and to collect new data as needed. The GAMA Priority Basin Project used the existing monitoring data along with newly collected data to characterize the water quality of the primary aquifer system. The CDPH database provided additional water-quality data for the spatially weighted and grid-based approaches to estimating aquifer-scale proportions for a wide range of constituents. CDPH data were not used to provide data for grid wells for VOCs, pesticides, or perchlorate because reporting limits for these constituents in the CDPH database generally were not sufficiently low enough to differentiate between "low" and "moderate" concentrations.

Three approaches were used to select CDPH inorganic constituent data for each grid cell where the USGS did not sample for inorganic constituents. The first approach was to identify CDPH data collected during the current period (May 20, 2005, to May 19, 2008) for any USGS-grid well not sampled for inorganic constituents by the USGS. Analytical results obtained from the CDPH database were reviewed for cation-anion charge balance, a commonly used qualitycontrol criterion for water-sample analysis (Hem, 1985). Because water is electrically neutral, the total positive charge on dissolved cation species in a water sample must equal the total negative charge on dissolved anion species. Cation-anion imbalance was calculated as the absolute difference between the total cations and total anions divided by the sum of the cations and anions, expressed as a percentage:

$$
\text { percent difference }=\left(\frac{\mid \sum \text { cations }-\sum \text { anions } \mid}{\sum \text { cations }+\sum \text { anions }}\right) \times 100,
$$

where

$\sum$ cations is the sum of calcium, magnesium, sodium, and potassium, in milliequivalents per liter (meq/L), and

$\sum$ anions is the sum of chloride, sulfate, fluoride, nitrate, and bicarbonate, in meq/L.

An imbalance, or percentage difference, greater than or equal to 5 percent indicates uncertainty in the quality of the data. The most recent CDPH data from the current period for the USGS-grid wells with missing data were evaluated to determine whether the cation/anion imbalance for CDPH data was less than 5 percent. If so, the CDPH inorganic data for the well was selected for use as the grid well data for inorganic constituents for that well. It was assumed that if major-ion data were of acceptable quality, then the data for trace elements, nutrients, and radiochemical constituents would also be of acceptable quality. This approach resulted in the selection of inorganic data from the CDPH database for 10 USGS-grid wells in the SCRC study unit. For identification purposes, data from the CDPH database for these grid wells were assigned GAMA identification numbers equivalent to the GAMA USGS-grid well number but with "DG" inserted between the study area prefix and sequence number (for example, CDPHgrid well SCRC-DG-B01 is the same well as USGS-grid well SCRC-B01, table A1).

If the first approach did not yield CDPH inorganic data for a grid cell, the second approach was to search the CDPH database to identify the highest ranked well within that cell with a cation/anion imbalance of less than 5 percent. This approach resulted in selecting CDPH inorganic data for wells not sampled by the USGS in five grid cells in the SCRC study unit. These five CDPH-grid wells were located within the same cell as the USGS-grid well but not necessarily right next to the USGS-grid well. To identify these new CDPH-grid wells, a well ID was created that added "DPH" after the study area prefix (for example, CDPH-grid well SCRC-DPH-B07 is in the same cell as USGS-grid well SCRC-B07 but is not the same well). There was one well, SCRC-B25, where the CDPH-grid well, SCRC-DPH-B25, was the same as the USGS-understanding well, SCRC-U04. Data collected by the USGS from SCRC-U04 were used to supplement the data from well SCRC-B25 when available.

If the second approach failed to produce a well from the CDPH database having a cation-anion imbalance less than 5 percent or there were insufficient data to evaluate a charge balance, the third approach was to select the highest ranked well in the CDPH database with any of the needed inorganic data. This approach resulted in the selection of one USGS-grid well in the SCRC study unit from which some CDPH inorganic data (usually nutrient data) were available. Because the well was a USGS-grid well, a well ID was created that added "DG" to the GAMA ID (for example, well SCRC-DG-B15).

The result of these approaches was one grid well per cell with data from the USGS database, the CDPH database, or both databases. Inorganic data for $16 \mathrm{CDPH}$-grid wells in the CDPH database were used (fig. A1). Data were not available for all inorganic constituents from all $16 \mathrm{CDPH}$-grid wells. Table 2 in the report shows the number of USGS- and $\mathrm{CDPH}$-grid wells with data for each inorganic constituent. In combination with USGS-grid well inorganic data (32 wells), some inorganic data were available for 49 of the 61 grid cells. Most of the cells without a grid well were located in the coastal areas of the Santa Ynez River Valley and San Antonio Creek Valley groundwater basins. 
Table A1. Nomenclature and construction information for USGS-grid and USGS-understanding wells and CDPH-grid wells, South Coast Range-Coastal study unit, California GAMA Priority Basin Project.

[CDPH, California Department of Public Health; GAMA, Groundwater Ambient Monitoring and Assessment Program; SCRC-B, South Coast RangeCoastal study unit Basins study area; SCRC-H, South Coast Range-Coastal study unit Uplands study area; SCRC-U, South Coast Range-Coastal study unit understanding well; SCRC-DG, South Coast Range-Coastal study unit grid well with supplemental CDPH data; SCRC-DPH, CDPH grid well; ft, feet; LSD, land surface datum; na, not available; USGS, U.S. Geological Survey; —, not applicable]

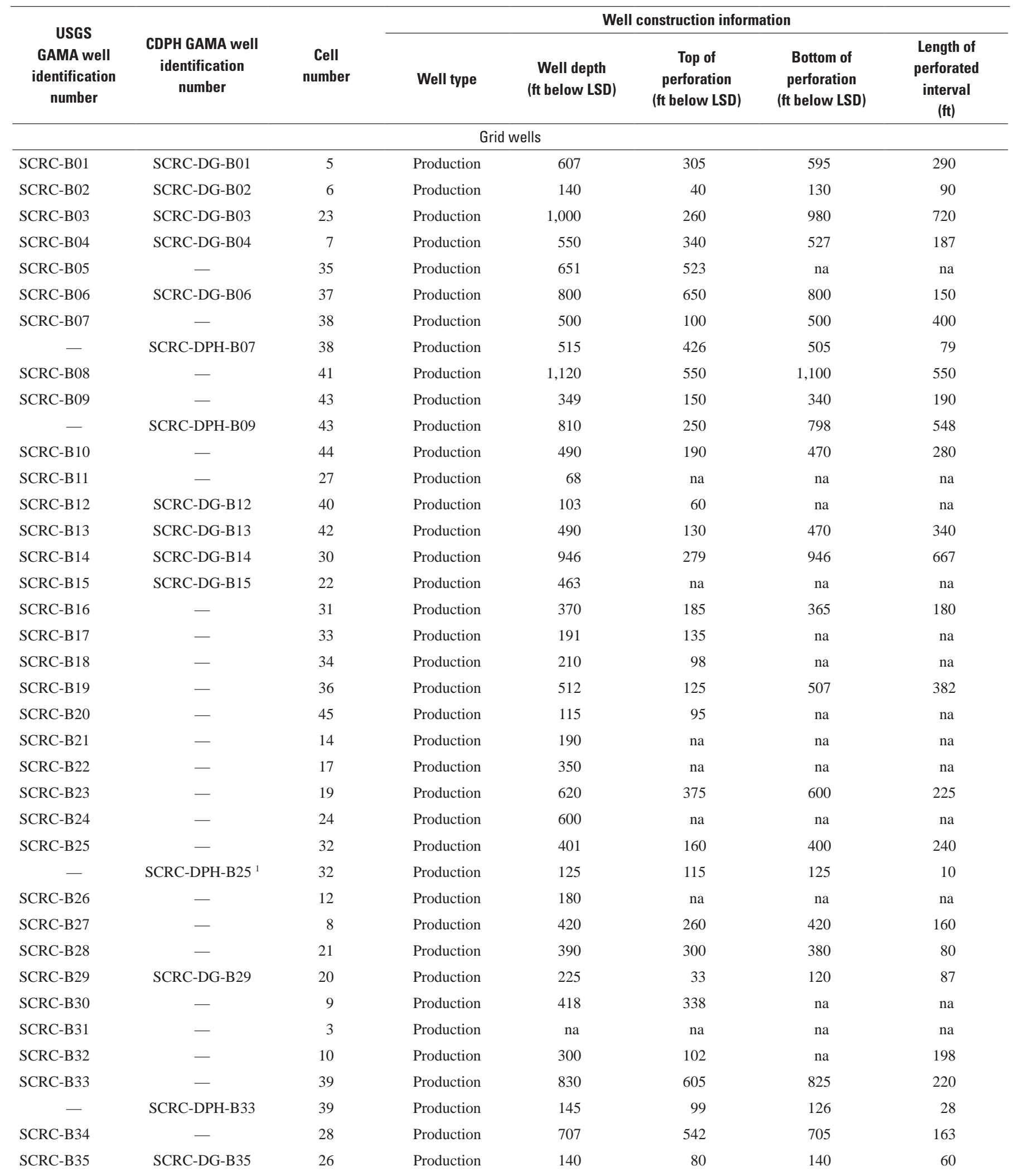


Table A1. Nomenclature and construction information for USGS-grid and USGS-understanding wells and CDPH-grid wells, South Coast Range-Coastal study unit, California GAMA Priority Basin Project.-Continued

[CDPH, California Department of Public Health; GAMA, Groundwater Ambient Monitoring and Assessment Program; SCRC-B, South Coast RangeCoastal study unit Basins study area; SCRC-H, South Coast Range-Coastal study unit Uplands study area; SCRC-U, South Coast Range-Coastal study unit understanding well; SCRC-DG, South Coast Range-Coastal study unit grid well with supplemental CDPH data; SCRC-DPH, CDPH grid well; ft, feet; LSD, land surface datum; na, not available; USGS, U.S. Geological Survey; —, not applicable]

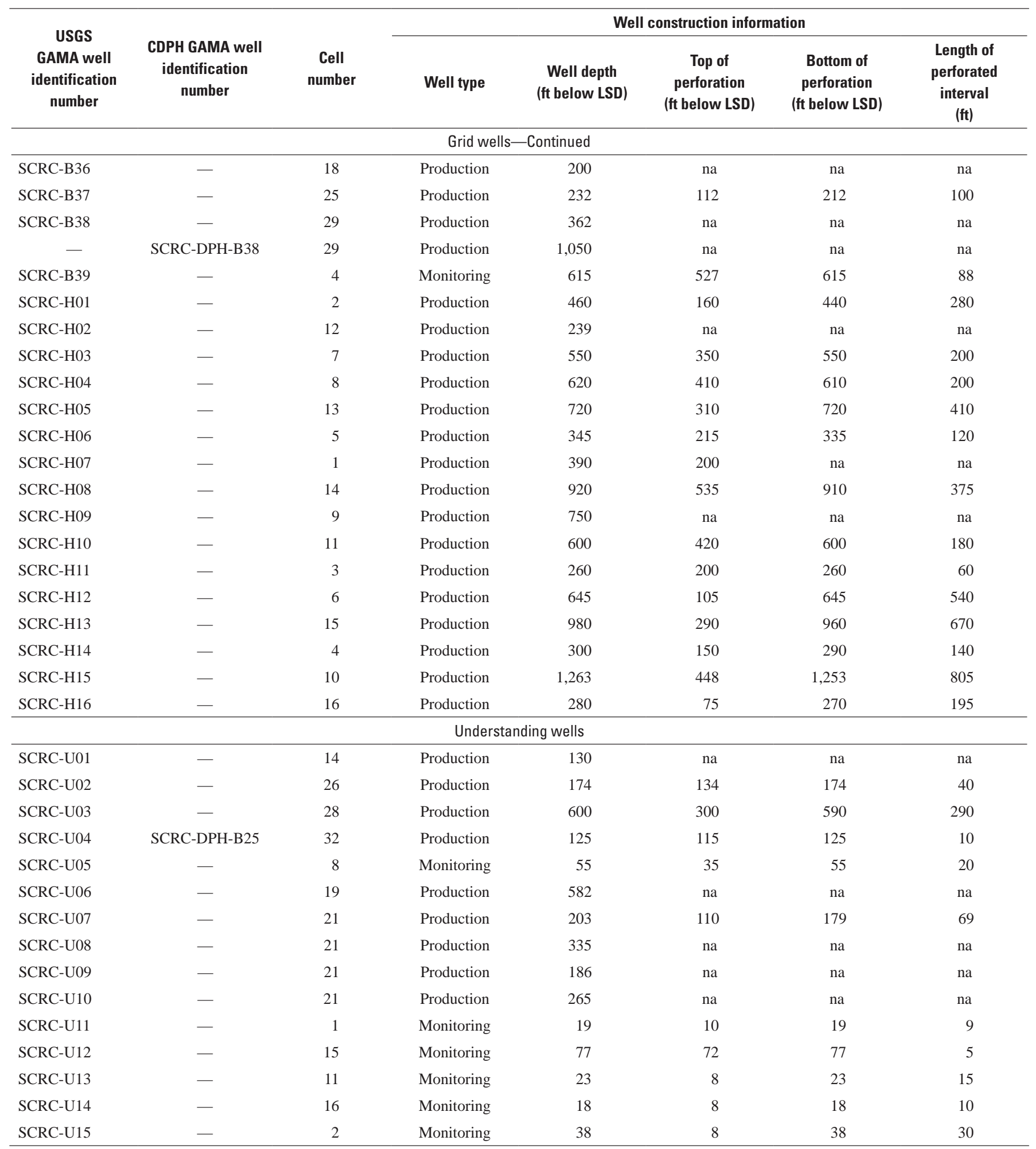

${ }^{1}$ This well was also sampled as USGS-understanding well SCRC-U04. 


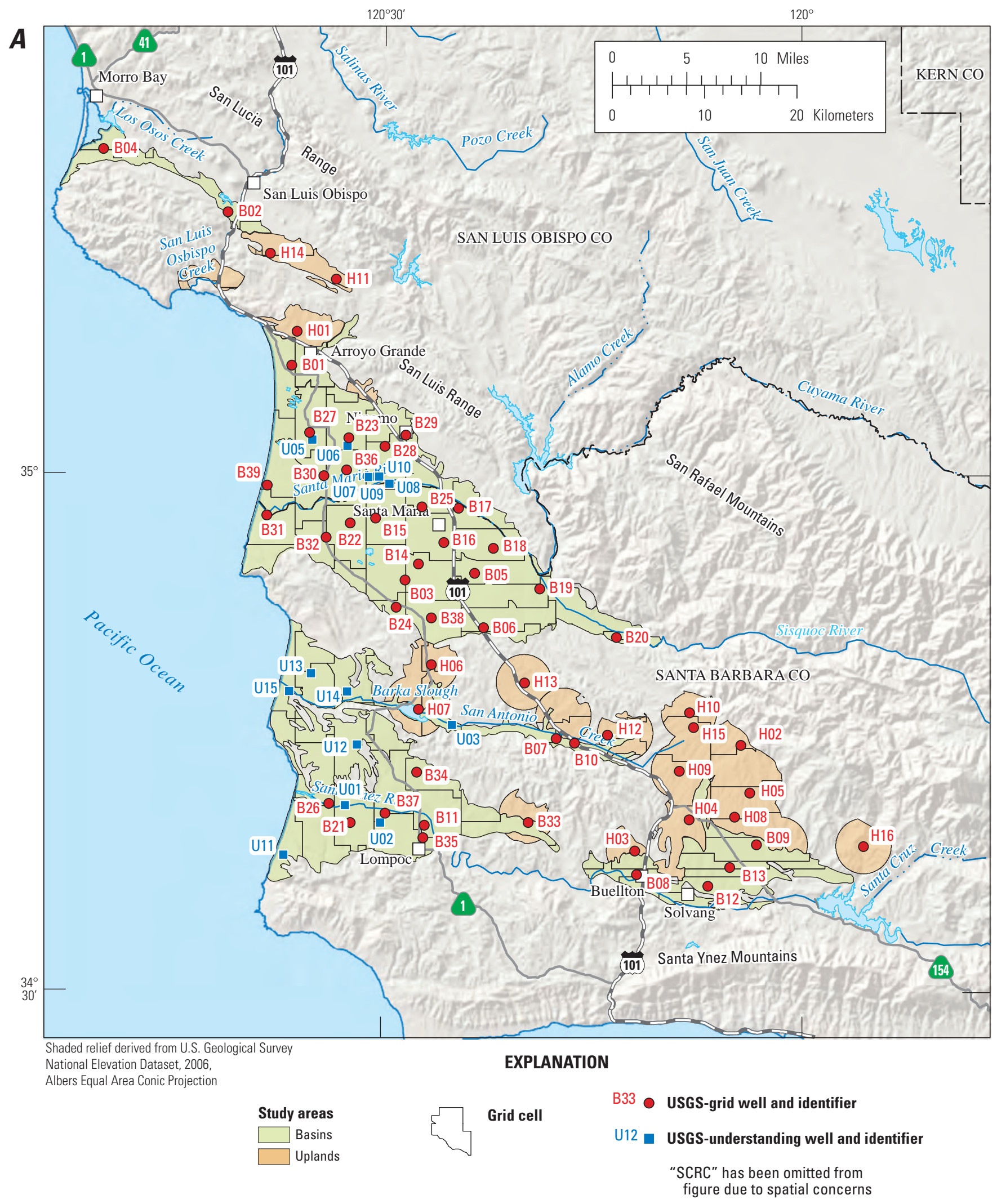

Figure A1. Identifiers and locations of (A) USGS-grid and USGS-understanding wells sampled during May through November 2008 and $(B)$ CDPH-grid wells with data for inorganic constituents from the California Department of Public Health (CDPH), South Coast Range-Coastal study unit, California GAMA Priority Basin Project. 


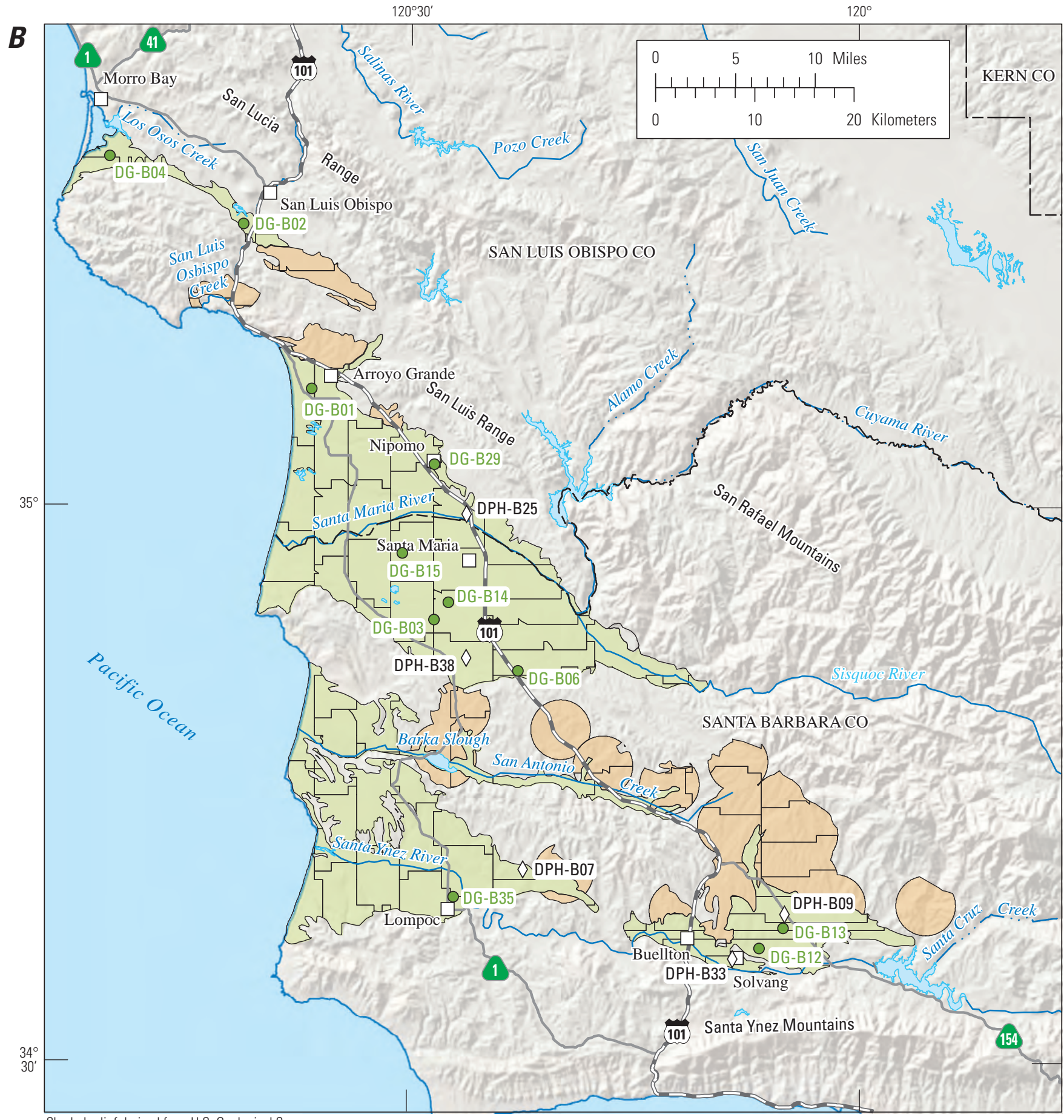

Shaded relief derived from U.S. Geological Survey National Elevation Dataset, 2006,

Albers Equal Area Conic Projection

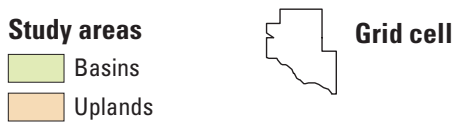

\section{EXPLANATION}

\section{DG-B12 $\bigcirc$ USGS- and CDPH-grid well and identifier DPH-B07 $\diamond \quad$ CDPH-grid well and identifier}

"SCRC" has been omitted from figure due to spatial concerns

Figure A1.-Continued. 


\section{Appendix B. Comparison of CDPH and GAMA Priority Basin Data}

CDPH and USGS-GAMA data were compared to assess the validity of combining data from these different sources. Because laboratory reporting levels for most organic constituents and trace elements were substantially lower for USGS-GAMA data than for CDPH data (table 2), only relatively high concentrations of constituents could be compared; as a result, there were insufficient data from which to evaluate agreement between CDPH and USGS-GAMA data. However, concentrations of major ions and nitrate, which generally are prevalent and have concentrations substantially above reporting levels, could be compared for each well using data from both sources.

Comparisons were made for inorganic constituents that were analyzed by the USGS-GAMA Priority Basin Project and for which CDPH data were available within the most recent 3-year interval. Major-ion and nitrate data were available from 11 to 13 wells from the SCRC study unit in the USGS and the CDPH databases for 10 constituents (calcium, magnesium, sodium, potassium, alkalinity, chloride, sulfate, total dissolved solids, nitrate, and fluoride). A nonparametric signed-rank test indicated no significant differences between the paired USGS-GAMA and CDPH data for seven of these constituents. The three constituents that showed significant differences were sodium, chloride, and alkalinity. However, the median relative percent difference (RPD, absolute difference of the two values divided by the average of the two values and multiplied by 100) calculated for these three data pairs was less than 20 percent, similar to the RPDs for the other seven constituents. This suggests that the observed differences for sodium, chloride, and alkalinity are negligible as pertains to the needs of this report. Trace element data were available for four to eight wells in the SCRC study unit in the USGS and CDPH databases for eight constituents (arsenic, barium, boron, cadmium, chromium, iron, manganese, and vanadium). A nonparametric signed-rank test indicated no significant differences between the paired USGS-GAMA and CDPH data for all eight trace elements. Although differences between the paired datasets occurred for a few wells, most sample pairs plotted close to a 1-to-1 line (fig. B1). These direct comparisons indicated that the GAMA and CDPH inorganic data were not significantly different.
Piper diagrams show the relative abundance of major cations and anions (on a charge equivalent basis) as a percentage of the total ion content of the water (ig. B2). Piper diagrams often are used to define groundwater type (Hem, 1985). Combined GAMA Priority Basin Project and CDPH major-ion data for grid wells were plotted on Piper diagrams (Piper, 1944) along with all CDPH major-ion data from the current period to determine whether the groundwater types in grid wells were similar to groundwater types observed historically in the study unit. All cation/anion data in the CDPH database with a cation/anion balance of less than 5 percent were retrieved and plotted on these Piper diagrams for comparison with grid well data.

The range of water types for grid wells and other wells from the CDPH database for the current period were similar (fig. B2). Most wells in the SCRC study unit were classified as mixed cation-mixed anion type waters, indicating that no single cation accounted for more than 50 percent of the total cations, and no single anion accounted for more than 50 percent of the total anions. The most common cations were calcium and magnesium, although some samples also contained a high percentage of sodium. Bicarbonate and sulfate were the dominant anions in these waters, although a few samples contained a high percentage of chloride. Waters in a minority of wells were classified as sodium-bicarbonate, magnesium-bicarbonate, mixed cation-bicarbonate, mixed cation-chloride, mixed cation-sulfate, magnesium-mixed anion, or sodium-mixed anion type waters, indicating sodium, magnesium, bicarbonate, chloride, or sulfate accounted for more than 50 percent of the total cations or anions.

The determination that the range of relative abundance of major cations and anions in grid wells (34 wells) is similar to the range of those in the selected CDPH-other wells (32 wells) indicates that the grid wells represent the diversity of water types present within the SCRC study unit. However, there was one minor difference between grid well data and CDPH-other well data. Two CDPH-other wells with a sodiumbicarbonate water type are located in the Uplands study area just north of the Santa Maria River Valley. The USGS-grid well (SCRC-H01) located just west of these wells has a mixed cation-mixed anion water type. 
$\boldsymbol{A}$

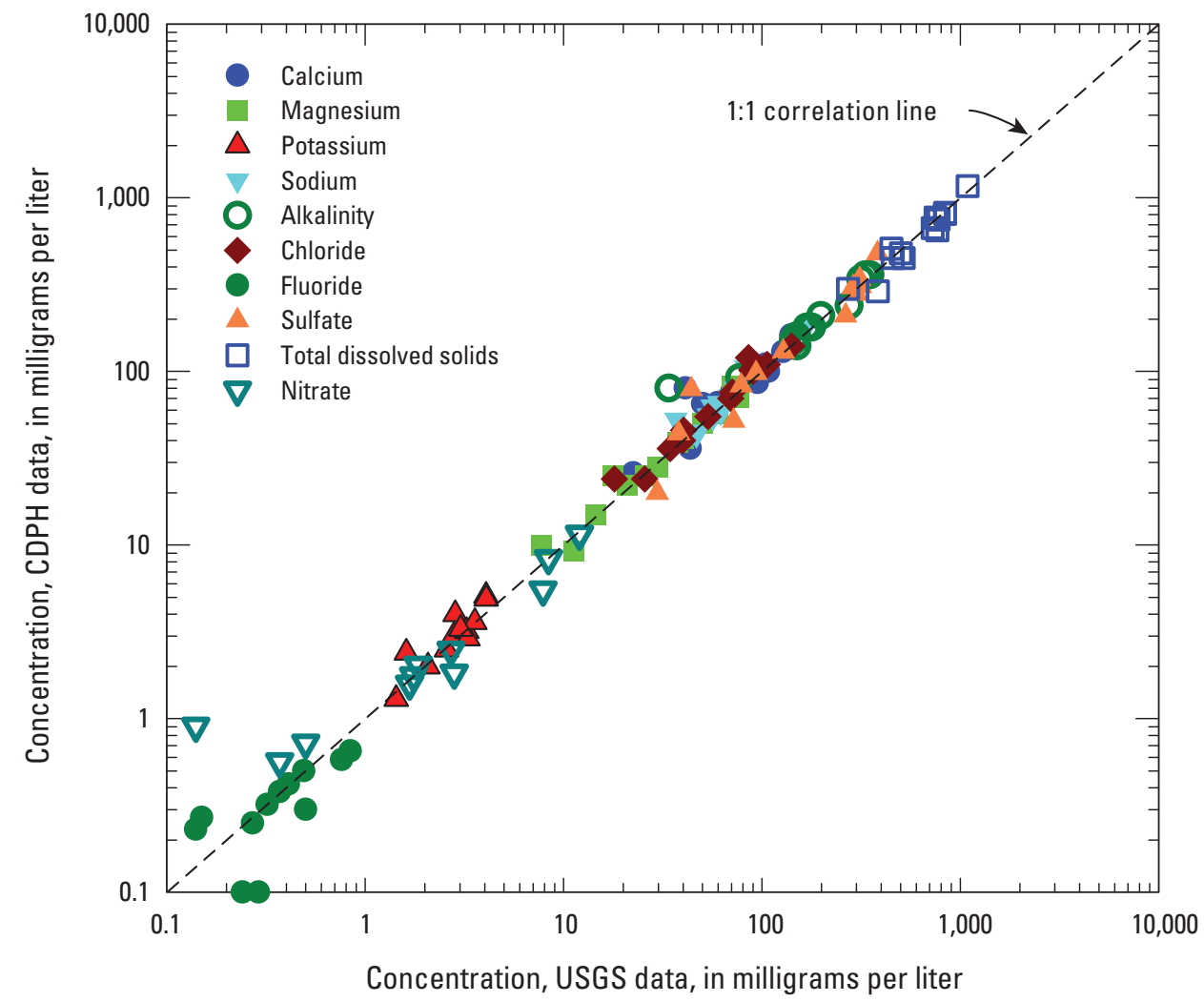

$\boldsymbol{B}$

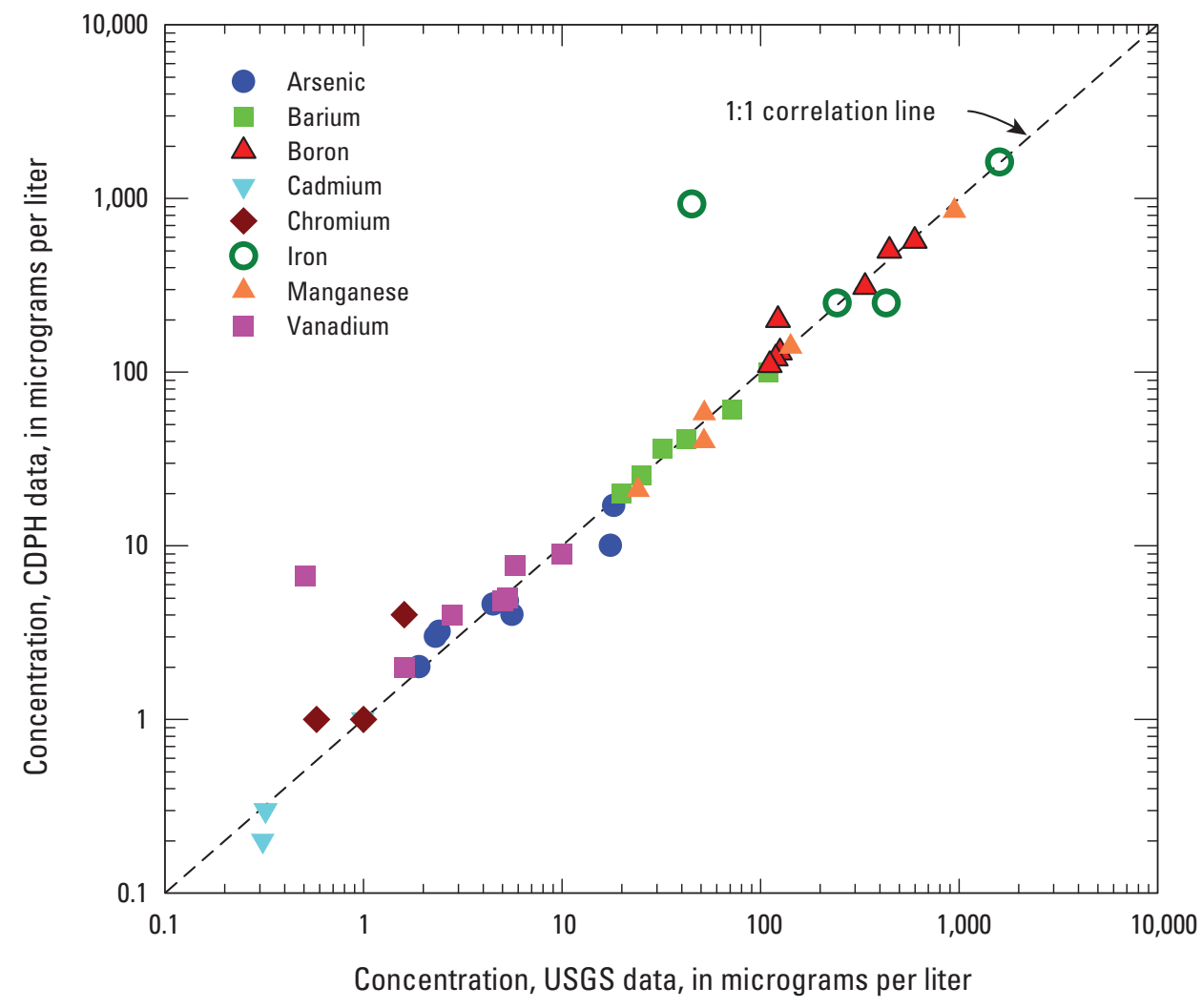

Figure B1. Paired inorganic concentrations from wells sampled in the South Coast Range-Coastal study unit (May through November 2008) and the most recent available analysis in the California Department of Health Services (May 20, 2005, to May 19, 2008) for $(A)$ major ions and nitrate and $(B)$ trace elements, California GAMA Priority Basin Project. 


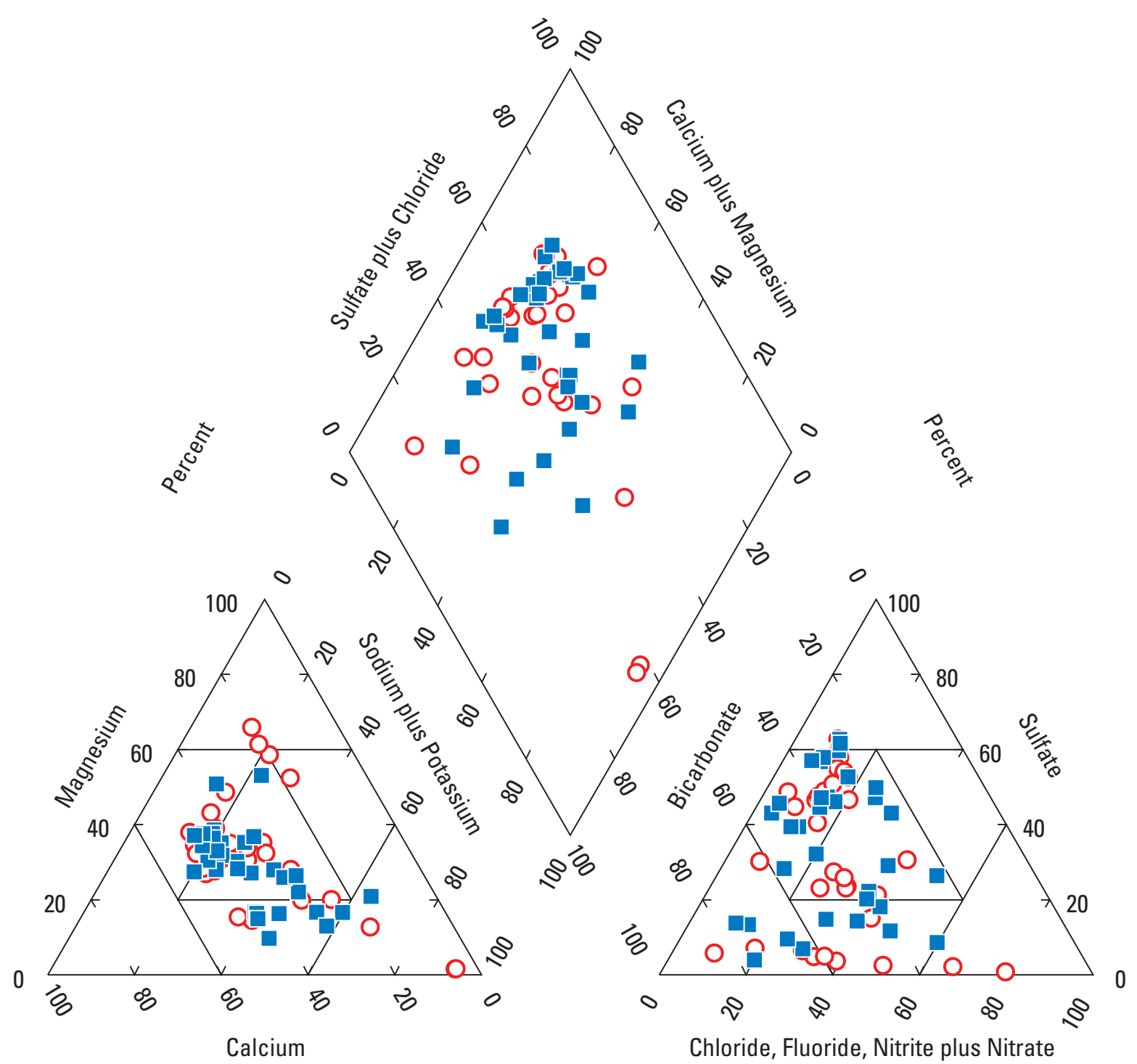

Percent

\section{EXPLANATION}

\section{USGS-grid well \\ ○ CDPH well}

Figure B2. USGS- and CDPH-grid wells and all other wells in the California Department of Public Health database with a charge imbalance of less than 5 percent in the South Coast Range-Coastal study unit, California GAMA Priority Basin Project. 


\section{Appendix C. Calculation of Aquifer-Scale Proportions}

Two statistical approaches—grid-based and spatially weighted-were selected to evaluate the aquifer-scale proportions of the primary aquifer system in the SCRC study unit with high, moderate, or low relative-concentrations (concentration relative to its water-quality benchmark) of constituents. Raw detection frequencies also were calculated for individual constituents, but were not used for estimating aquifer-scale proportions because this method creates spatial bias towards regions with large numbers of wells.

\section{Grid-Based Calculation}

One well in each grid cell, a "grid well," was used to represent the primary aquifer system. Most grid wells sampled for this study were USGS-grid wells. The relativeconcentration for each constituent (concentration relative to its water-quality benchmark) was evaluated for each grid well. The areal proportion of the primary aquifer system with high relative-concentrations was calculated by dividing the number of cells with concentrations greater than the benchmark (relative-concentration greater than 1 ) by the total number of grid wells in the study unit (Belitz and others, 2010). Proportions containing moderate and low relativeconcentrations were calculated similarly. Confidence intervals for grid-based aquifer-scale proportions were computed using the Jeffreys interval for the binomial distribution (Brown and others, 2001). The grid-based estimate is spatially unbiased. However, the grid-based approach may not detect constituents that are present at high relative-concentrations in small proportions of the primary aquifer system.

The grid-based aquifer-scale proportions for constituent classes also were calculated on a one-value-per-cell basis. A cell with a high relative-concentration for any constituent in the class is defined as a high cell, and the high proportion is the number of high cells divided by the number of cells with data for any of the constituents in that class. The moderate proportion for the constituent class is calculated similarly, except that a cell already defined as high cannot also be defined as moderate. The grid-based aquifer-scale proportion for the low category was calculated similarly, such that a cell could only be low if the relative-concentration was neither moderate nor high for any constituent in the class. The proportions for the high, moderate, and low categories were expected to total 100 percent, except for small differences as a result of rounding.

\section{Spatially Weighted Calculation}

The spatially weighted calculation of aquifer-scale proportions uses the most recent value for a constituent from all wells in the CDPH database with data in the 3-year interval prior to USGS-GAMA sampling (May 20, 2005, to May 19,
2008) in the SCRC study unit, from all USGS-grid well data, and from selected USGS-understanding well data. The spatially weighted approach computes the aquifer-scale areal proportion by using the percentage of wells with high relativeconcentrations from all the wells in each cell, instead of using data from only one well (Belitz and others, 2010). For each constituent, the high aquifer-scale proportion was computed by calculating the proportion of wells with high relativeconcentrations in each grid cell and dividing by the number of cells (Belitz and others, 2010):

$$
\begin{gathered}
P_{i}=\frac{W_{\text {high }}}{W_{\text {total }},} \\
P_{S U}=\frac{\sum_{i=1}^{n} P_{i}}{n},
\end{gathered}
$$

where

$$
\begin{gathered}
P_{i} \quad \begin{array}{c}
\text { is the proportion of wells in the } i^{\text {th }} \text { cell with } \\
\text { high relative-concentrations, }
\end{array} \\
W_{\text {total }} \quad \begin{array}{c}
\text { is the number of wells in the } i^{\text {th }} \text { cell with data } \\
\text { for the constituent, }
\end{array} \\
W_{\text {high }} \quad \begin{array}{c}
\text { is the number of wells in the } i^{\text {th }} \text { cell with high } \\
\text { relative-concentrations, }
\end{array} \\
P_{S U} \quad \begin{array}{c}
\text { is the aquifer-scale proportion for the study } \\
\text { unit, and }
\end{array} \\
n \quad \begin{array}{l}
\text { is the number of cells with data for the } \\
\text { constituent. }
\end{array}
\end{gathered}
$$

Similar procedures were used to calculate the proportions of moderate and low relative-concentrations. The resulting proportions were spatially unbiased (Isaaks and Srivastava, 1989).

\section{Raw Detection Frequencies}

The raw detection frequencies of wells with high relativeconcentrations for constituents were calculated using the same data used for the spatially weighted approach. Raw detection frequency is the percentage (frequency) of wells in the study unit with high relative-concentrations. However, raw detection frequencies are spatially biased because the wells in the CDPH database and USGS-understanding wells are not uniformly distributed. Consequently, high relativeconcentrations for wells clustered in a particular area represent a small part of the primary aquifer system and could be given a disproportionately high weight compared to that given by spatially unbiased approaches. Raw detection frequencies of high relative-concentrations are provided for reference in this report but were not used to assess aquifer-scale proportions. 


\section{Appendix D. Attribution of Potential Explanatory Factors}

\section{Well Construction Information}

Well construction data were from driller's logs or from information provided by the well owner. Well identification verification procedures are described by Mathany and others (2010). Well depths and depths to the top and bottom of the perforated interval for USGS-grid, USGS-understanding, and CDPH-grid wells are listed for the SCRC study unit in table A1. Wells were classified as production wells or monitoring wells. Production wells pump groundwater from the aquifer to a distribution system and generally are screened over long intervals. Monitoring wells are short-screened wells installed exclusively for monitoring purposes.

\section{Land-Use Classification}

Land use was classified using an enhanced version of the satellite-derived (30-m pixel resolution) nationwide USGS National Land Cover Dataset (Nakagaki and others, 2007). This dataset has been used in previous national and regional studies relating land use to water quality (Gilliom and others, 2006; Paul and others, 2007). The dataset characterizes land cover during the early 1990s. The imagery is classified into 25 land-cover classifications (Nakagaki and Wolock, 2005). These 25 land-cover classifications were assigned to 3 general land-use classifications - urban, agricultural, and natural. Land-use statistics for the SCRC study unit and for circles with a radius of $500 \mathrm{~m}$ around each well (table D1) were assigned using the USGS National Land Cover Dataset (Johnson and Belitz, 2009).

\section{Septic Systems}

Septic tank density was determined from housing characteristics data from the 1990 U.S. Census (U.S. Census Bureau, 1990). The density of septic tanks in each housing census block was calculated from the number of tanks and block area. The density of septic tanks around each well was calculated from the area-weighted mean of the block densities for blocks within a 500-m buffer around the well location (Tyler Johnson, U.S. Geological Survey, written commun., 2009) (table D1).

\section{Formerly Leaking Underground Fuel Tanks}

Density for formerly leaking underground fuel tanks (LUFTs) was determined from data obtained from the Geographic Information Management System GeoTracker (California Environmental Protection Agency, 2001). The density is a measure of the number of tanks in a Thiessen polygon in square kilometers. The boundaries of the Thiessen polygons are created by bisecting the distance between all surrounding LUFTs. For instance, if a tank is surrounded by four tanks each 1,000 $\mathrm{m}$ away, then the Thiessen polygon will be drawn exactly one-half of the distance to each tank $(500 \mathrm{~m})$, resulting in a polygon that is relatively small and therefore of high density. The density is calculated by dividing the number of tanks at a single location (usually one) and dividing it by the total area of the polygon. If the nearest tanks are many kilometers away, then the polygon will be large, and therefore the density will be relatively low. This measure was added because two wells could each be $100 \mathrm{~m}$ away from a LUFT, but one could be surrounded by 10 nearby tanks and the other secluded without another tank for $100 \mathrm{~km}$. The Thiessen polygon method is a non-interpolated measure of density that has the added value of being able to handle extreme high and low densities equally well. LUFT density data and distance to nearest LUFT for each USGS-grid and understanding well and CDPH-grid well are in table D1.

\section{Groundwater Age Classification}

Groundwater dating techniques indicate the time since the groundwater was last in contact with the atmosphere. Techniques used to estimate groundwater residence times or 'age' include those based on tritium (for example, Tolstikhin and Kamenskiy, 1969), tritium combined with its decay product helium-3 (for example, Takaoka and Mizutani, 1987; Poreda and others, 1988; Schlosser and others, 1988), carbon-14 $\left({ }^{14} \mathrm{C}\right)$ content (for example, Vogel and Ehhalt, 1963; Plummer and others, 1993), and dissolved noble gases, particularly helium-4 accumulation (for example, Davis and DeWiest, 1966; Andrews and Lee, 1979; Cey and others, 2008; Kulongoski and others, 2008).

Tritium is a short-lived radioactive isotope of hydrogen with a half-life of 12.32 years (Lucas and Unterweger, 2000). Tritium is produced naturally in the atmosphere from the interaction of cosmogenic radiation with nitrogen (Craig and Lal, 1961), by above-ground nuclear explosions (Michel, 1989), and by the operation of nuclear reactors. Tritium enters the hydrologic cycle following oxidation to tritiated water. Natural background levels of tritium in precipitation are approximately 3 to 15 tritium units (TU) (Craig and Lal, 1961; Clark and Fritz, 1997). Above-ground nuclear explosions resulted in a large increase in tritium values in precipitation, beginning in about 1952 and peaking in 1963 at values over 1,000 TU in the northern hemisphere (Michel, 1989; Solomon and Cook, 2000). Radioactive decay over a period of 50 years would decrease tritium values of $10 \mathrm{TU}$ to $0.6 \mathrm{TU}$. 
Table D1. Land-use classification, septic systems, and formerly leaking underground fuel tank information for USGS-grid and USGS-understanding wells, and CDPH-grid wells for inorganic constituents, South Coast Range-Coastal study unit, California GAMA Priority Basin Project.

[Land-use classification based on 500-meter radius around each well (Johnson and Belitz, 2009). Number of septic tanks in 500-meter radius around each well (U.S. Census Bureau, 1990). Number of formerly leaking underground fuel tanks within a Thiessen polygon in square kilometers, data from Geographic Information Management System GeoTracker (California Environmental Protection Agency, 2001). GAMA, Groundwater Ambient Monitoring and Assessment Program; SCRC-B, South Coast Range-Coastal study unit Basins study area; SCRC-H, South Coast Range-Coastal study unit Uplands study area; SCRC-U, South Coast Range-Coastal study unit understanding well; DG, South Coast Range-Coastal study unit grid well with supplemental CDPH data; DPH, CDPH-grid well; km², square kilometer; CDPH, California Department of Public Health; tanks $/ \mathrm{km}^{2}$, tanks per square kilometer]

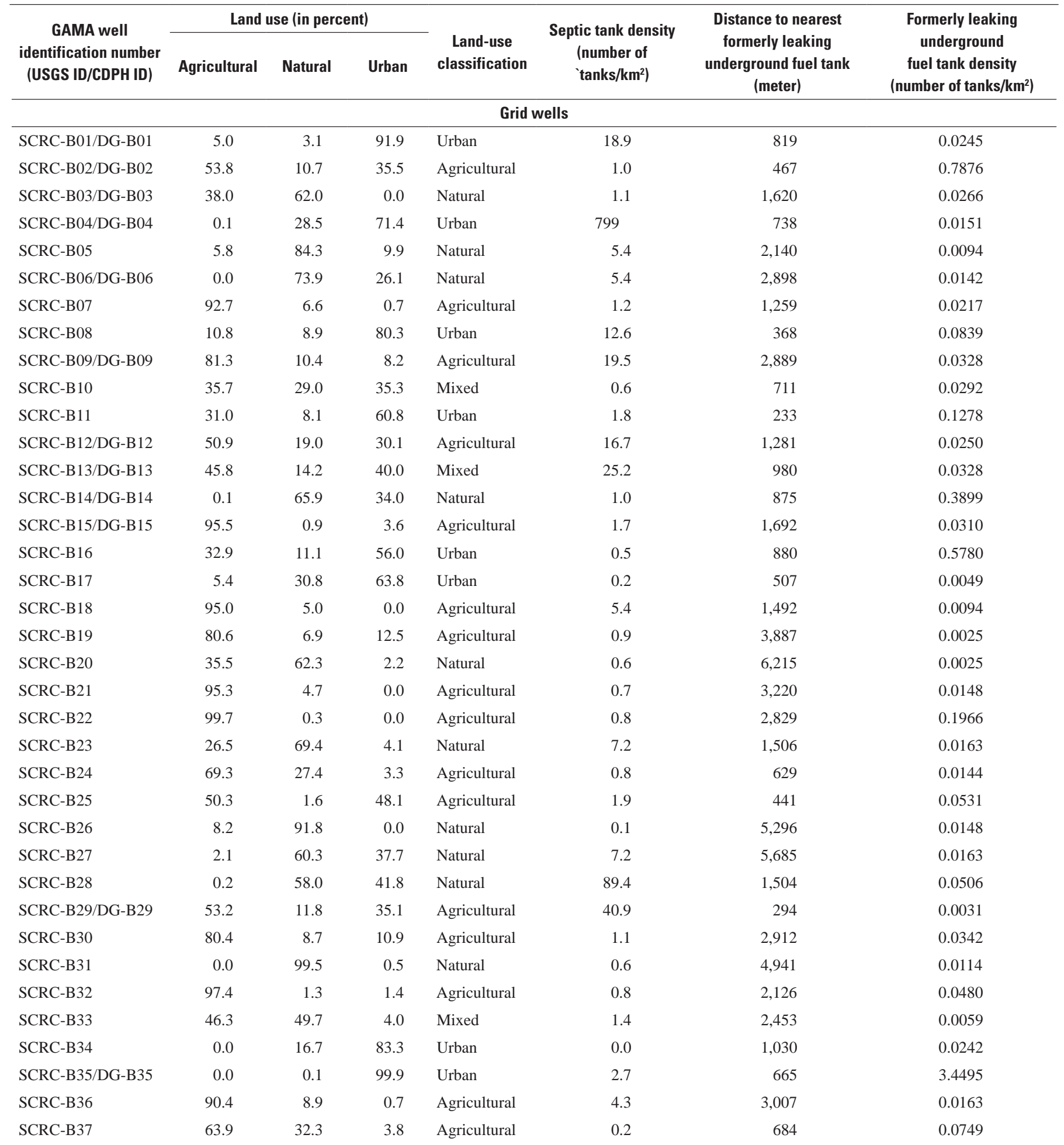


Table D1. Land-use classification, septic systems, and formerly leaking underground fuel tank information for USGS-grid and USGS-understanding wells, and CDPH-grid wells for inorganic constituents, South Coast Range-Coastal study unit, California GAMA Priority Basin Project.-Continued

[Land-use classification based on 500-meter radius around each well (Johnson and Belitz, 2009). Number of septic tanks in 500-meter radius around each well (U.S. Census Bureau, 1990). Number of formerly leaking underground fuel tanks within a Thiessen polygon in square kilometers, data from Geographic Information Management System GeoTracker (California Environmental Protection Agency, 2001). GAMA, Groundwater Ambient Monitoring and Assessment Program; SCRC-B, South Coast Range-Coastal study unit Basins study area; SCRC-H, South Coast Range-Coastal study unit Uplands study area; SCRC-U, South Coast Range-Coastal study unit understanding well; DG, South Coast Range-Coastal study unit grid well with supplemental CDPH data; DPH, CDPH-grid well; km², square kilometer; CDPH, California Department of Public Health; tanks $/ \mathrm{km}^{2}$, tanks per square kilometer]

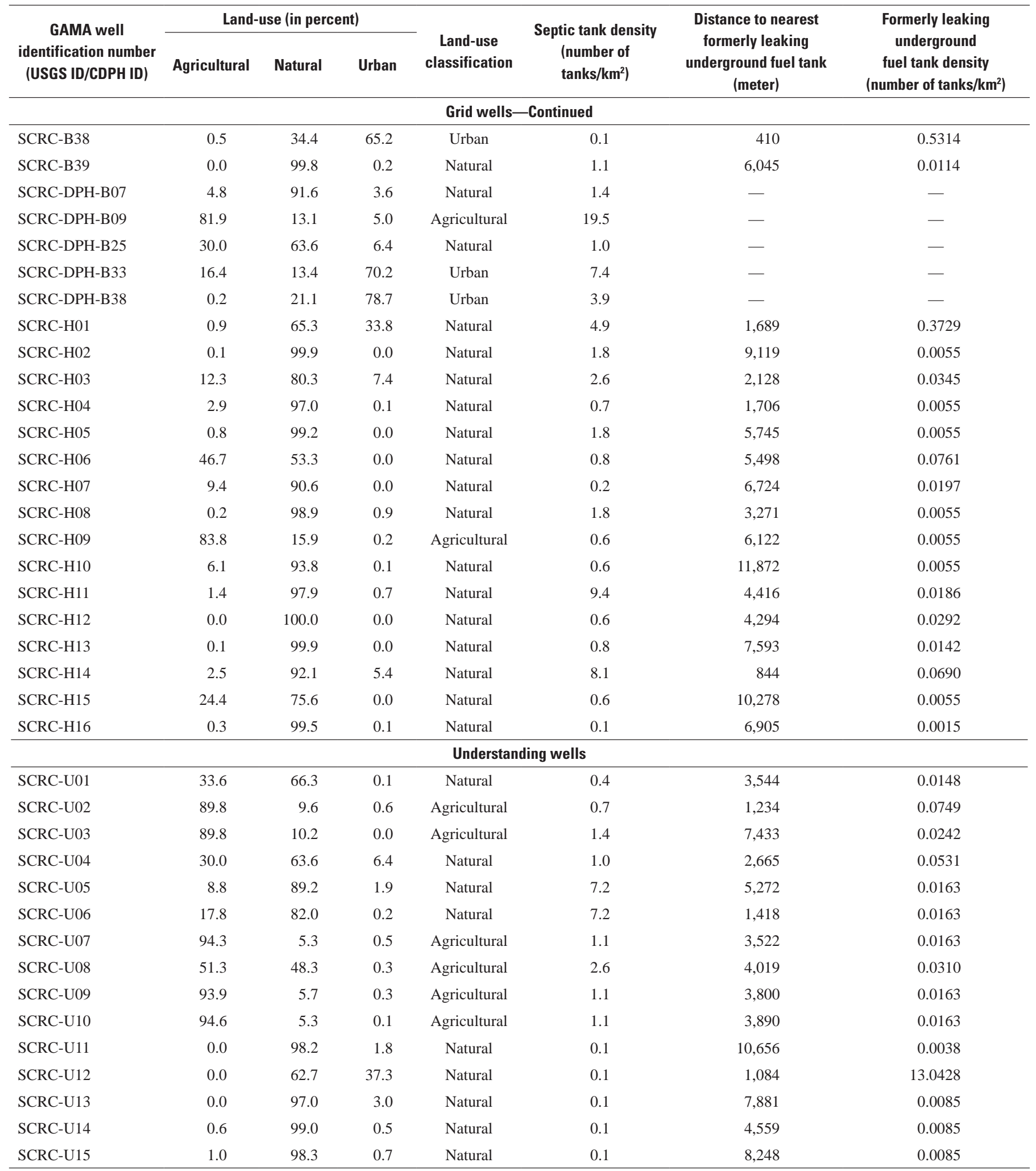


Previous investigations have used a range of tritium values from 0.3 to $1.0 \mathrm{TU}$ as thresholds for indicating presence of water that has exchanged with the atmosphere since 1952 (Michel, 1989; Plummer and others, 1993; Michel and Schroeder, 1994; Manning and others, 2005; Kulongoski and others, 2010). Tritium values greater than or equal to a threshold of 1.0 TU were defined as indicating the presence of groundwater recharged since 1952 for samples collected for the SCRC study unit. Using a tritium concentration of $1.0 \mathrm{TU}$ as the threshold in this study allows a slightly larger fraction of modern water to be present in pre-modern groundwater (Kulongoski and others, 2010; Landon and others, 2010). This higher threshold was used for this study because most of the wells were long-screened production wells and some mixing of waters of different ages likely occurred. Water recharged since 1952 is defined as "modern" groundwater.

${ }^{14} \mathrm{C}$ is a widely used chronometer based on the radiocarbon content of organic and inorganic carbon. Dissolved inorganic carbon species, carbonic acid, bicarbonate, and carbonate typically are used for ${ }^{14} \mathrm{C}$ dating of groundwater. ${ }^{14} \mathrm{C}$ is formed in the atmosphere by the interaction of cosmic-ray neutrons with nitrogen and, to a lesser degree, with oxygen and carbon, and by above-ground nuclear explosions. ${ }^{14} \mathrm{C}$ is incorporated into carbon dioxide and mixed throughout the atmosphere. The carbon dioxide enters the hydrologic cycle because it dissolves in precipitation and surface water in contact with the atmosphere. The ${ }^{14} \mathrm{C}$ content in groundwater reflects the time since the water was last exposed to the atmospheric ${ }^{14} \mathrm{C}$ source. ${ }^{14} \mathrm{C}$ has a half-life of about 5,700 years and can be used to estimate groundwater ages ranging from 1,000 to approximately 30,000 years before present (Clark and Fritz, 1997).

${ }^{14} \mathrm{C}$ data may be reported in units of percent modern (pM) or in units of percent modern carbon (pmc). ${ }^{14} \mathrm{C}$ data for the SCRC study unit (Mathany and others, 2010) are given in pM units as reported by the analyzing laboratory. ${ }^{14} \mathrm{C}$ data in $\mathrm{pM}$ units have been normalized for carbon isotopic fractionation based on a $\delta^{13} \mathrm{C}$ value of $-25 \%$ to account for biological process and exchange of carbon dioxide between the air and surface water that fractionate both ${ }^{13} \mathrm{C}$ and ${ }^{14} \mathrm{C}$ (Mook and Van Der Plicht, 1999). However, most of the variation of $\delta^{13} \mathrm{C}$ in the dissolved inorganic carbon in groundwater is caused by water-rock interaction rather than by biological or gaseous exchange processes; thus, use of normalized ${ }^{14} \mathrm{C}$ data may not be appropriate. Geochemical calculations to correct for changes in the isotopic composition of dissolved inorganic carbon by water-rock interaction must be made using ${ }^{14} \mathrm{C}$ data that have not been normalized (Plummer and others, 2004). Un-normalized ${ }^{14} \mathrm{C}$ data are reported in pmc units. Data were converted from $\mathrm{pM}$ to pmc using following equation derived from Plummer and others (2004):

$$
p m c=\frac{p M\left(1+\frac{\delta^{13} C}{1,000}\right)^{2}}{0.975^{2}}
$$

where

$p M \quad$ is the ${ }^{14} \mathrm{C}$ value in units of $\mathrm{pM}$, and

$\delta^{13} \mathrm{C} \quad$ is the measured ${ }^{13} \mathrm{C}$ composition in units of per mil.

Calculated radiocarbon ages in this study are referred to as "uncorrected" because they have not been adjusted to consider water-rock interactions, such as exchanges with sedimentary sources of carbon (Fontes and Garnier, 1979). Estimated errors in radiocarbon ages are up to \pm 20 percent. Groundwater with a ${ }^{14} \mathrm{C}$ activity of greater than $90 \mathrm{pmc}$ is reported as having an age of less than 1,000 years; no attempt was made to refine ${ }^{14} \mathrm{C}$ ages less than 1,000 years. Measured values of pmc can be greater than 100 because the definition of the ${ }^{14} \mathrm{C}$ content in "modern" carbon does not include the excess ${ }^{14} \mathrm{C}$ produced in the atmosphere by above-ground nuclear weapons testing (Clark and Fritz, 1997). For the SCRC study unit, ${ }^{14} \mathrm{C}$ activity less than $90 \mathrm{pmc}$ was defined as indicating the presence of groundwater recharged before 1952 (Kulongoski and others, 2010; Landon and others, 2010). Water recharged before 1952 is defined as "pre-modern" groundwater.

Helium (He) is a naturally occurring inert gas initially included during the accretion of the Earth and later produced by radioactive decay of lithium, uranium, and thorium in the planet's crust and mantle. Helium $\left({ }^{3} \mathrm{He}\right.$ plus $\left.{ }^{4} \mathrm{He}\right)$ concentrations in groundwater often exceed the expected solubility equilibrium values as a result of air entrainment, or subsurface production of both isotopes, and their subsequent release into the groundwater (for example, Morrison and Pine, 1955; Andrews and Lee, 1979; Torgersen, 1980; Andrews, 1985; Torgersen and Clarke, 1985). Measured He concentrations in groundwater are the sum of several He components including

$$
H e_{\text {total }}=H e_{e q}+H e_{a}+H e_{\text {trit }}+H e_{\text {terr }} \text {, }
$$

where

$$
\begin{aligned}
& \mathrm{He}_{\text {total }} \text { is the total amount of helium measured in the } \\
& \text { groundwater sample; } \\
& \mathrm{He}_{e q} \quad \text { is the helium derived from equilibration with } \\
& \text { the atmosphere at the time of recharge; } \\
& \mathrm{He}_{a} \text { is the helium derived from entrained air } \\
& \text { bubbles ("excess" air); } \\
& \mathrm{He}_{\text {trit }} \quad \text { is the helium produced by radioactive decay } \\
& \text { of tritium in the sample; and } \\
& \mathrm{He}_{\text {terr }} \text { is the helium produced by radioactive } \\
& \text { decay of uranium and thorium in aquifer } \\
& \text { materials or emanating from deeper in the } \\
& \text { Earth's crust or mantle. }
\end{aligned}
$$


$\mathrm{He}_{\mathrm{eq}}, \mathrm{He}_{\mathrm{a}}$, and $\mathrm{He}_{\text {terr }}$ all consist of helium-3 ( $\left.{ }^{3} \mathrm{He}\right)$ and helium-4 $\left({ }^{4} \mathrm{He}\right)$; however, $\mathrm{He}_{\text {trit }}$ consists only of ${ }^{3} \mathrm{He}$.

The presence of $\mathrm{He}_{\text {terr }}$ in groundwater, from its production in aquifer material or deeper in the crust, is indicative of long groundwater residence times (Andrews and Lee, 1979; Kulongoski and others, 2008). For the purpose of estimating groundwater residence times, the amount of $\mathrm{He}_{\text {terr }}$ is defined as the concentration of the total measured helium minus the fraction as a result of air equilibration $\left(\mathrm{He}_{\mathrm{eq}}\right)$ and entrained air bubbles $\left(\mathrm{He}_{\mathrm{a}}\right)$. For the purposes of this study, the percentage of $\mathrm{He}_{\text {terr }}\left(\% \mathrm{He}_{\text {terr }}\right)$ is used to identify groundwater with residence times greater than 100 years. $\% \mathrm{He}_{\text {terr }}$ is defined as the concentration of $\mathrm{He}_{\text {terr }}$ divided by the $\mathrm{He}_{\text {total }}$ in the sample (corrected for air-bubble entrainment):

$$
\% H e_{\text {terr }}=\frac{H e_{\text {terr }}}{H e_{\text {total }}-H e_{a}} \times 100
$$

( $\mathrm{He}_{\text {trit }}$ is neglected in calculation of $\% \mathrm{He}_{\text {terr }}$ because it typically is very small.) For the SCRC study unit, values of $\% \mathrm{He}_{\text {terr }}$ $>5$ were defined as indicating the presence of pre-modern groundwater similar to the procedures for other GAMA Priority Basin Project study units (Kulongoski and others, 2010; Landon and others, 2010).

Tritium concentrations, $\% \mathrm{He}_{\text {terr }}$, carbon-14 (as pmc), carbon-14 ages, and age classifications are reported in table D2. While more sophisticated lumped parameter models for analyzing age distributions that incorporate mixing are available (Cook and Böhlke, 2000), use of these alternative models to understand age mixtures was not needed for the assessments in this report. Classification into modern, mixed, and pre-modern categories was sufficient to provide an appropriate and useful characterization for the purposes of examining groundwater quality.

For the SCRC, groundwater ages were classified as follows:

\begin{tabular}{lcll}
\hline \multicolumn{1}{c}{ Classification } & Tritium (TU) & Carbon-14 (pmc) & \multicolumn{1}{c}{$\% \mathrm{He}_{\text {terr }}$} \\
\hline Modern & $\geq 1.0$ & $\geq 90$ or no data & $<5$ \\
Modern or Mixed & $\geq 1.0$ & no data & $\geq 5$ or no data \\
Mixed & $\geq 1.0$ & $<90$ & any value \\
Pre-modern or Mixed & $<1.0 \quad$ no data & $<5$ or no data \\
Pre-modern & $<1.0 \quad<90$ & any value \\
Pre-modern & $<1.0$ & no data & $\geq 5$ \\
\hline
\end{tabular}

\section{Geochemical Conditions}

Geochemical conditions investigated as potential explanatory variables in this report include oxidation-reduction characteristics, DO concentrations, and pH (table D3). Oxidation-reduction (redox) conditions and $\mathrm{pH}$ influence the mobility of many organic and inorganic constituents (Hem, 1985; McMahon and Chapelle, 2008). Along groundwater flow paths, redox conditions commonly proceed along a well-documented sequence of Terminal Electron Acceptor Processes (TEAP); one TEAP typically dominates at a particular time and aquifer location (Chapelle and others, 1995; Chapelle, 2001). The predominant TEAPs are oxygenreducing (oxic), nitrate-reducing, manganese-reducing, ironreducing, sulfate-reducing, and methanogenesis. The presence of redox-sensitive chemical species indicating more than one TEAP may indicate (1) the discharge from the well includes mixed waters from different redox zones upgradient of the well, (2) the well is screened across more than one redox zone, or (3) there is spatial heterogeneity in microbial activity in the aquifer. In addition, different redox couples often are not consistent, indicating electrochemical disequilibrium in groundwater (Lindburg and Runnells, 1984) that further complicates the assessments of redox conditions.

In this report, redox conditions were represented in two ways: dissolved oxygen concentration and classified redox state. Dissolved oxygen concentrations were measured at USGS-grid and understanding wells (Mathany and others, 2010), but are not reported in the CDPH database (table D3). Redox conditions were classified based on dissolved oxygen, nitrate, manganese, iron, and sulfate concentrations by using the classification scheme of McMahon and Chapelle (2008) (table D3). An automated workbook program was used to assign the redox classification to each sample (Jurgens and others, 2009). For wells without USGS inorganic constituent data, the most recent data within the current period (May 20, 2005, to May 19, 2008) for that well in the CDPH database were used. 
Table D2. Groundwater age classification information for USGS-grid and USGS-understanding wells, South Coast Range-Coastal study unit, California GAMA Priority Basin Project, May-November 2008.

[Sample classified as pre-modern if recharged prior to 1952. Samples classified as modern if recharged after 1952. Sample is classified as mixed if sample contains both modern and pre-modern water. GAMA, Groundwater Ambient Monitoring and Assessment Program; SCRC-B, South Coast Range-Coastal study unit Basins study area; SCRC-H, South Coast Range-Coastal study unit Uplands study area; SCRC-U, South Coast Range-Coastal study unit understanding well; TU, tritium units; <, less than; >, greater than; nc, not collected; -, no data; USGS, U.S. Geological Survey]

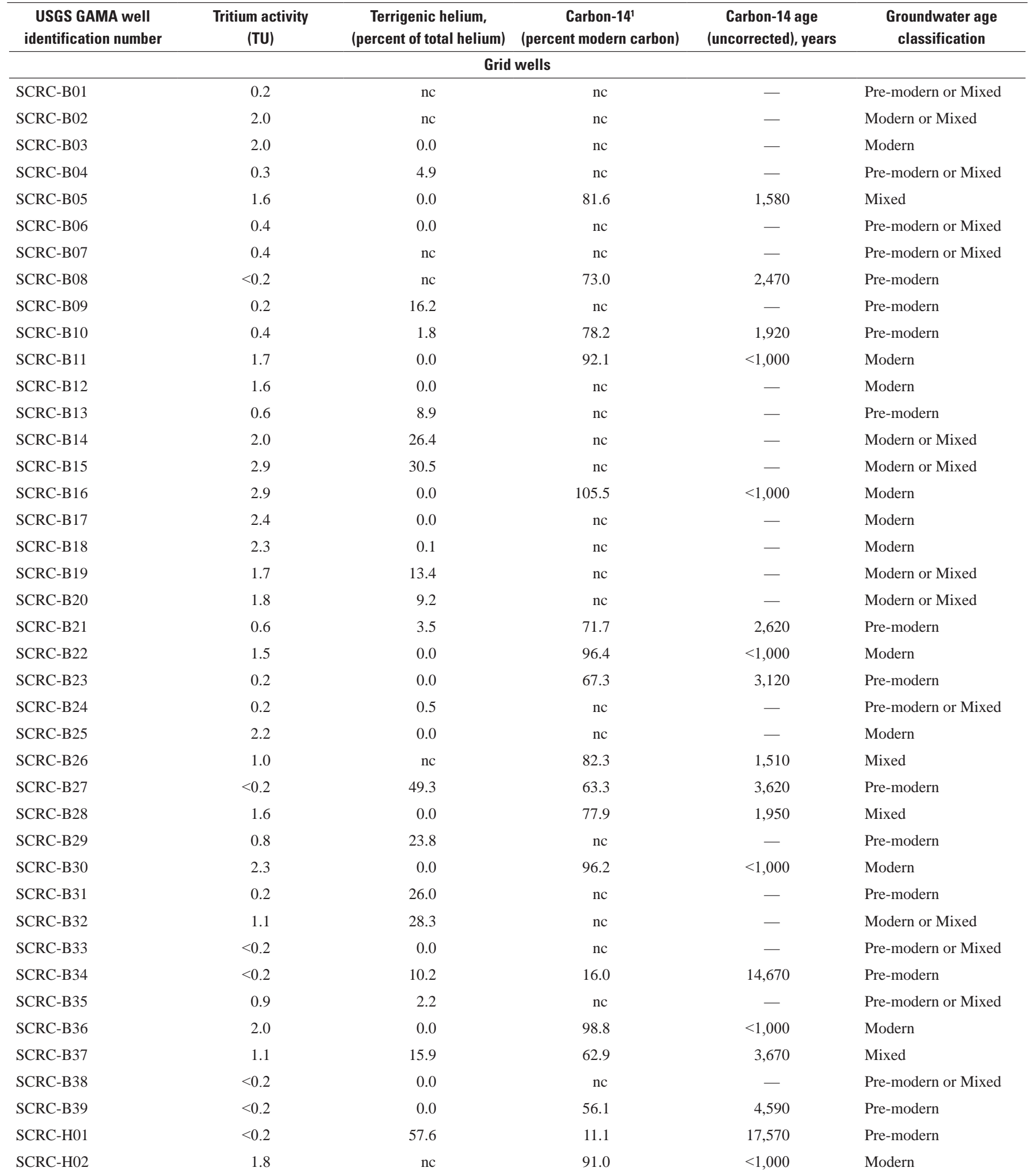


Table D2. Groundwater age classification information for USGS-grid and USGS-understanding wells, South Coast Range-Coastal study unit, California GAMA Priority Basin Project, May-November 2008._Continued

[Sample classified as pre-modern if recharged prior to 1952. Samples classified as modern if recharged after 1952. Sample is classified as mixed if sample contains both modern and pre-modern water. GAMA, Groundwater Ambient Monitoring and Assessment Program; SCRC-B, South Coast Range-Coastal study unit Basins study area; SCRC-H, South Coast Range-Coastal study unit Uplands study area; SCRC-U, South Coast Range-Coastal study unit understanding well; TU, tritium units; <, less than; >, greater than; nc, not collected; - , no data; USGS, U.S. Geological Survey]

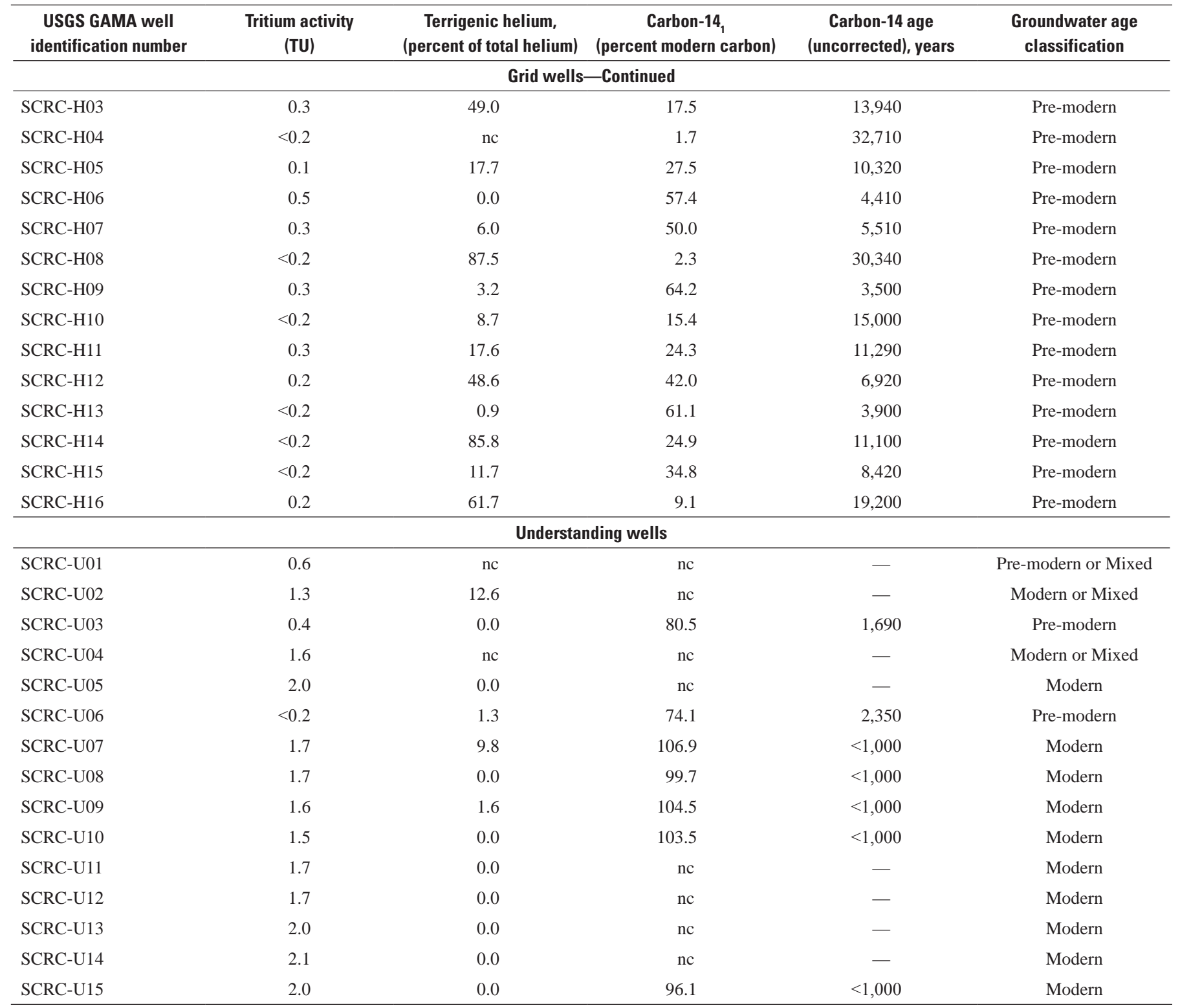

${ }^{1}$ Carbon-14 data shown in this table are different from data provided in the data series report by Mathany and others (2010) because the carbon-14 data have not been normalized by the associated carbon-13 data. 
Table D3. Oxidation-reduction classification and pH for USGS-grid and USGS-understanding wells, South Coast Range-Coastal study unit, California GAMA Priority Basin Project.

[Redox category and redox process determined using the algorithm from Jurgens and others (2009); Oxic, dissolved oxygen greater than or equal to ( $\geq$ ) $0.5 \mathrm{mg} / \mathrm{L}$; anoxic/suboxic, dissolved oxygen $<0.5 \mathrm{mg} / \mathrm{L}$; indeterminate, insufficient data to determine redox classification; mixed, oxic and anoxic processes are present. Abbreviations GAMA, Groundwater Ambient Monitoring and Assessment Program; SCRC-B, South Coast Range-Coastal study unit Basins study area; SCRC-H, South Coast Range-Coastal study unit Uplands study area; SCRC-U, South Coast Range-Coastal study unit understanding well; DG, South Coast Range-Coastal study unit grid well with supplemental CDPH data; DPH, CDPH grid well; redox, oxidation reduction; mg/L, milligrams per liter; $\mu \mathrm{g} / \mathrm{L}$, micrograms per liter; <, less than; nc, not collected; Fe, iron; $\mathrm{SO}_{4}$, sulfate; Mn, manganese]

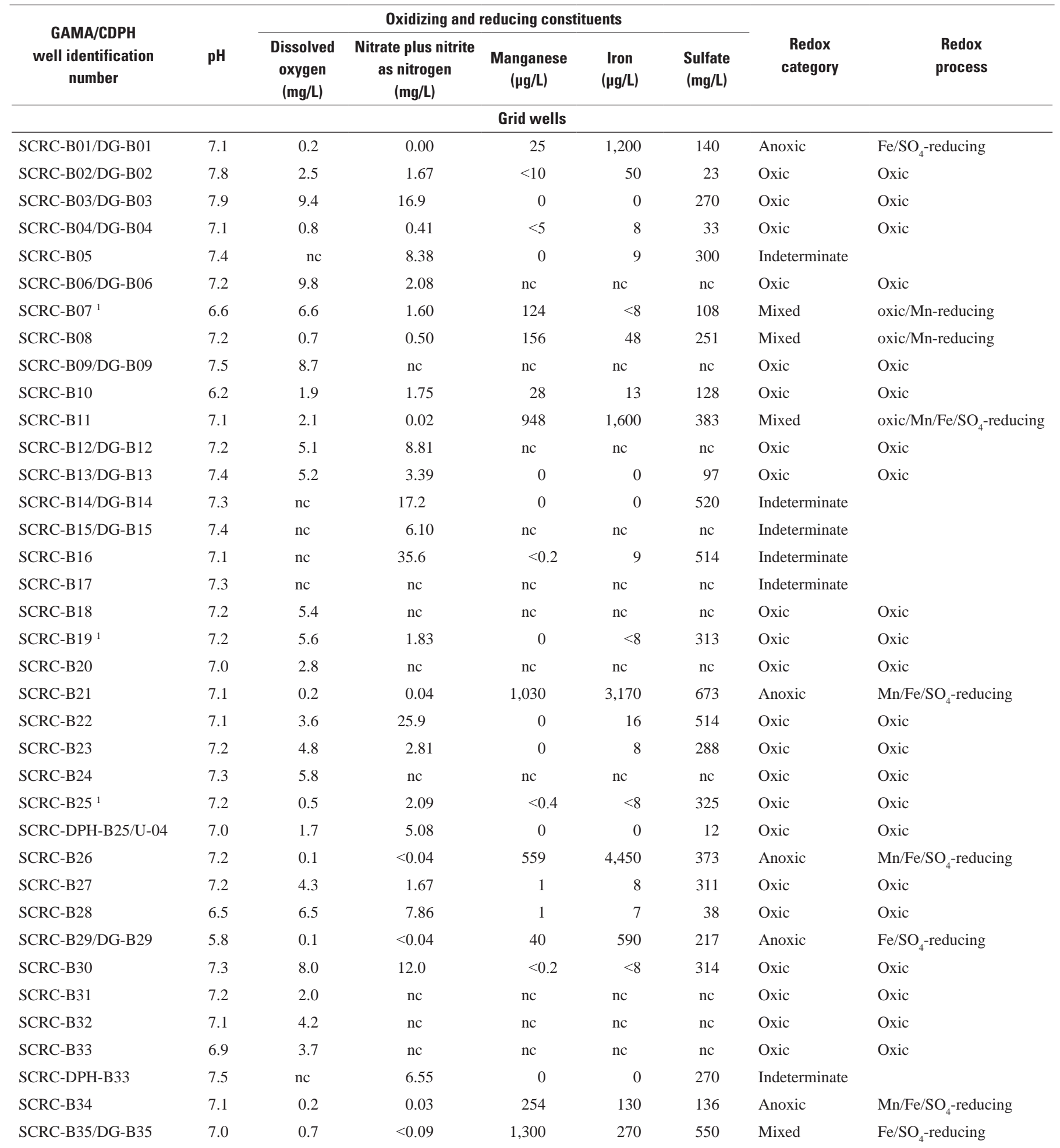


Table D3. Oxidation-reduction classification and pH for USGS-grid and USGS-understanding wells, South Coast Range-Coastal study unit, California GAMA Priority Basin Project.-Continued

[Redox category and redox process determined using the algorithm from Jurgens and others (2009); Oxic, dissolved oxygen greater than or equal to ( $\geq$ ) $0.5 \mathrm{mg} / \mathrm{L}$; anoxic/suboxic, dissolved oxygen $<0.5 \mathrm{mg} / \mathrm{L}$; indeterminate, insufficient data to determine redox classification; mixed, oxic and anoxic processes are present. Abbreviations GAMA, Groundwater Ambient Monitoring and Assessment Program; SCRC-B, South Coast Range-Coastal study unit Basins study area; SCRC-H, South Coast Range-Coastal study unit Uplands study area; SCRC-U, South Coast Range-Coastal study unit understanding well; DG, South Coast Range-Coastal study unit grid well with supplemental CDPH data; DPH, CDPH grid well; redox, oxidation reduction; mg/L, milligrams per liter; $\mu \mathrm{g} / \mathrm{L}$, micrograms per liter; <, less than; nc, not collected; Fe, iron; $\mathrm{SO}_{4}$, sulfate; Mn, manganese]

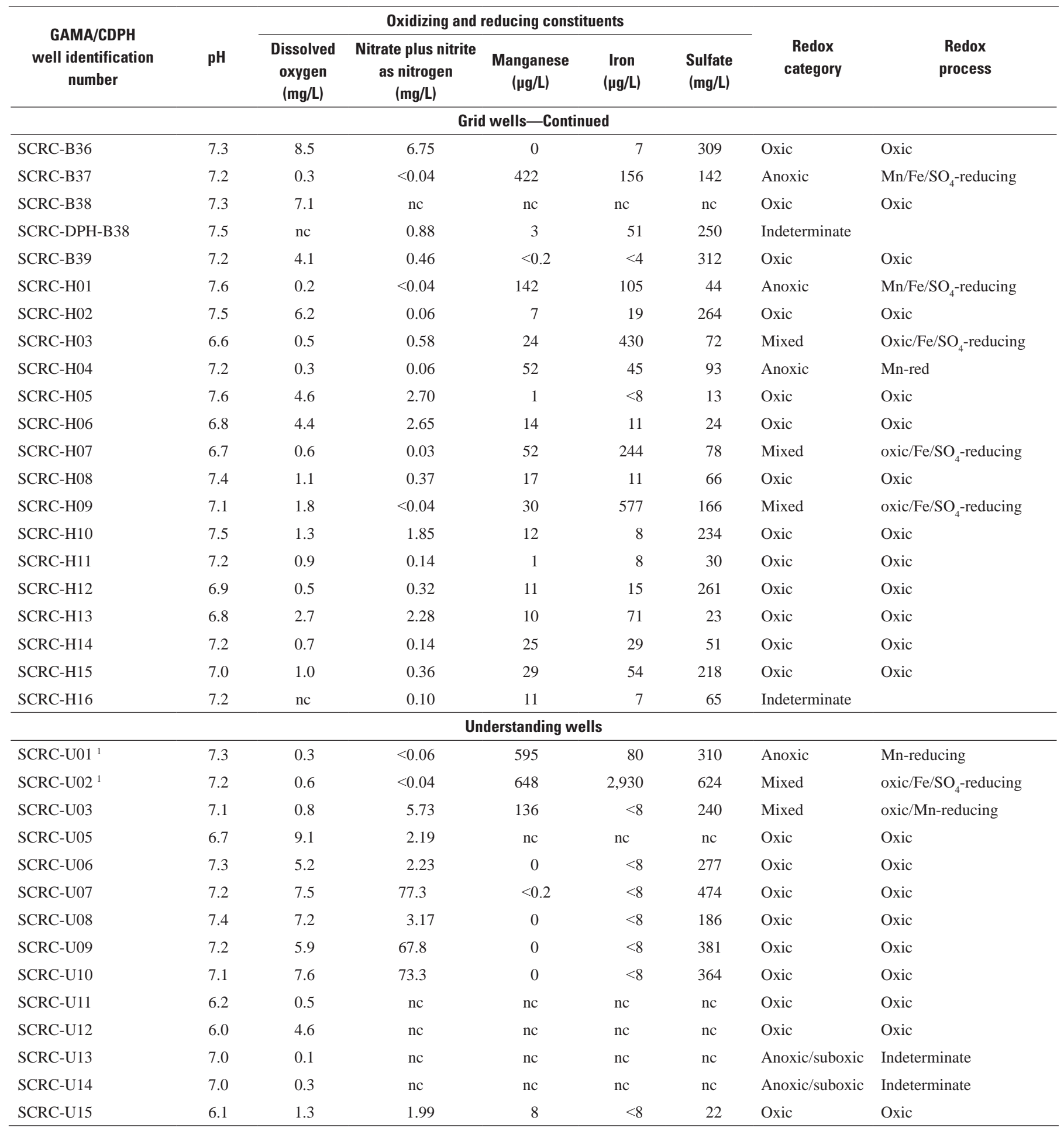

${ }^{1}$ Data for nitrate plus nitrite, manganese, iron, and sulfate were not collected by the GAMA Priority Basin Project but were collected by the USGS for another study during July-August 2008 except for SCRC-U01 data which were collected during August 2007. 


\section{Appendix E. Data not Published in the USGS Data-Series Report}

Data for noble gases and stable isotopes of nitrogen in dissolved nitrogen gas were not available in time for inclusion in the report by Mathany and others (2010). A brief discussion of the collection procedures and the associated data are given here.

Samples were collected from 61 wells in the SCRC study unit for analysis of dissolved noble gases. Dissolved noble gases were collected in $3 / 8$-inch-diameter copper tubes using reinforced nylon tubing connected to the hose bib at the wellhead. Groundwater was flushed through the tubing to dislodge bubbles before flow was restricted with a back pressure valve. Clamps on either end of the copper tube then were tightened, trapping a sample of groundwater for analyses of dissolved noble gases (Weiss, 1968). Samples were analyzed by the Lawrence Livermore National Laboratory using methods described by Moran and others (2002) and Eaton and others (2003). Data for noble gases are given in table E1.

Stable isotopes of nitrogen in dissolved nitrogen gas were determined using the samples collected for analysis of dissolved gases. Samples were collected from 12 wells in the SCRC study unit for analysis of dissolved gases. Dissolved gases were collected by bottom filling two 150-milliliter glass serum bottles that were first filled with groundwater, then submerged in a stainless container (at least 2 liters in size or larger) filled with groundwater. The discharge tube was slowly removed with water still flowing, and a rubber stopper was inserted to cap the bottle while the bottle was submerged in the water. These samples had no headspace or air bubbles inside the bottles and were sealed underwater to avoid atmospheric contamination. Samples were analyzed by the USGS Stable Isotope Laboratory in Reston, Virginia, using methods described in Revesz and others (1999), Tobias and others, (2007), and Green and others (2008). Stable isotope data for nitrogen in dissolved gases are given in table E1.
Stable isotopic compositions of nitrogen are reported as relative isotope ratios using the standard delta notation, $\delta^{15} \mathrm{~N} / \%$ (Coplen, 2011):

where

$$
\delta^{i} E=\left[\frac{R\left({ }^{i} E /{ }^{j} E\right)_{P}}{R\left({ }^{i} E / /^{j} E\right)_{s t d}}\right]-1,
$$

$$
\begin{gathered}
i \quad \begin{array}{c}
\text { is the atomic mass of the heavier isotope of } \\
\text { the element, } \\
\text { is the atomic mass of the lighter isotope of the } \\
\text { element, }
\end{array} \\
E \text { is the element (for this report, } N \text { for nitrogen), } \\
R_{p} \quad \begin{array}{c}
\text { is the isotope ratio of the heavier isotope of } \\
\text { the element }\left({ }^{i} E\right) \text { to the lighter isotope of } \\
\text { the element } \left.{ }^{j} E\right) \text { in the sample } P \text {, and }
\end{array} \\
R_{\text {std }} \quad \begin{array}{l}
\text { is the isotope ratio of the heavier isotope of } \\
\text { the element }\left({ }^{i} E\right) \text { to the lighter isotope of } \\
\text { the element }\left({ }^{j} E\right) \text { in the reference material. }
\end{array}
\end{gathered}
$$

The reference material nitrogen is atmospheric nitrogen gas, which is assigned a $\delta^{15} \mathrm{~N}$ value of 0 . Positive values indicate enrichment of the heavier isotope, and negative values indicate depletion of the heavier isotope, compared to the ratios observed in the standard reference material. 
Table E1. Results for analyses of helium isotope ratios, noble gases, and stable isotope ratios of nitrogen gas derived for samples collected for the South Coast Range-Coastal study unit, California GAMA Priority Basin Project, May-November 2008.

[Stable isotope nitrogen ratios are reported in the standard delta notation ( $\delta$ ), the ratio of the heavier isotope to the more common lighter isotope relative to a standard reference material. Abbreviations GAMA, Groundwater Ambient and Monitoring; $\mathrm{cm}^{3} \mathrm{STP} / \mathrm{g}^{-1} \mathrm{H}_{2} \mathrm{O}$, cubic centimeters at standard temperature and pressure per gram of water; $\mathrm{mg} / \mathrm{L}$, milligram per liter; N, nitrogen; nc, not collected; \%o, per mil]

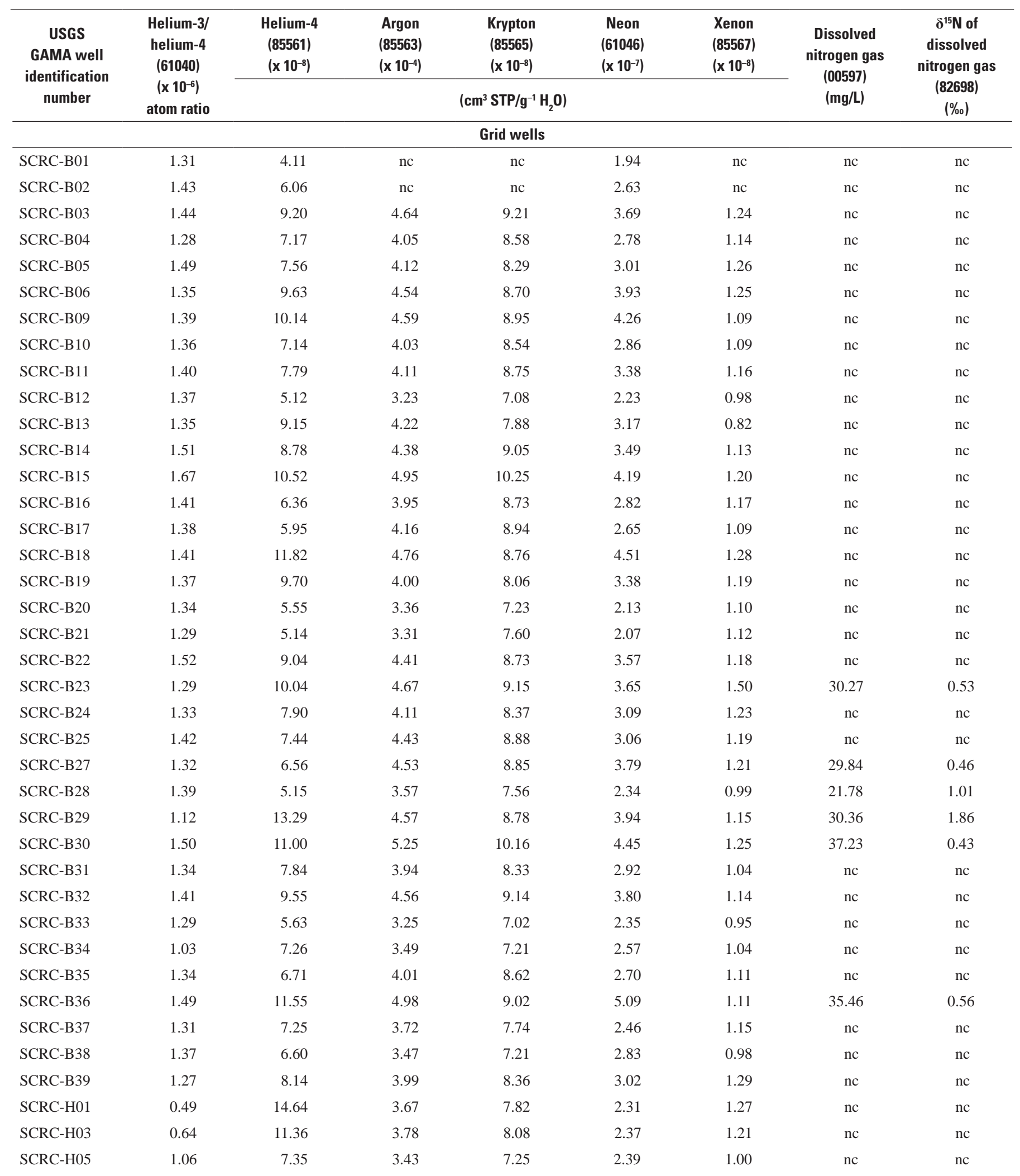


Table E1. Results for analyses of helium isotope ratios, noble gases, and stable isotope ratios of nitrogen gas derived for samples collected for the South Coast Range-Coastal study unit, California GAMA Priority Basin Project, May-November 2008. - Continued

[Stable isotope nitrogen ratios are reported in the standard delta notation $(\delta)$, the ratio of the heavier isotope to the more common lighter isotope relative to a standard reference material. Abbreviations GAMA, Groundwater Ambient and Monitoring; $\mathrm{cm}^{3} \mathrm{STP} / \mathrm{g}^{-1} \mathrm{H}_{2} \mathrm{O}$, cubic centimeters at standard temperature and pressure per gram of water; mg/L, milligram per liter; N, nitrogen; nc, not collected; \%, per mil]

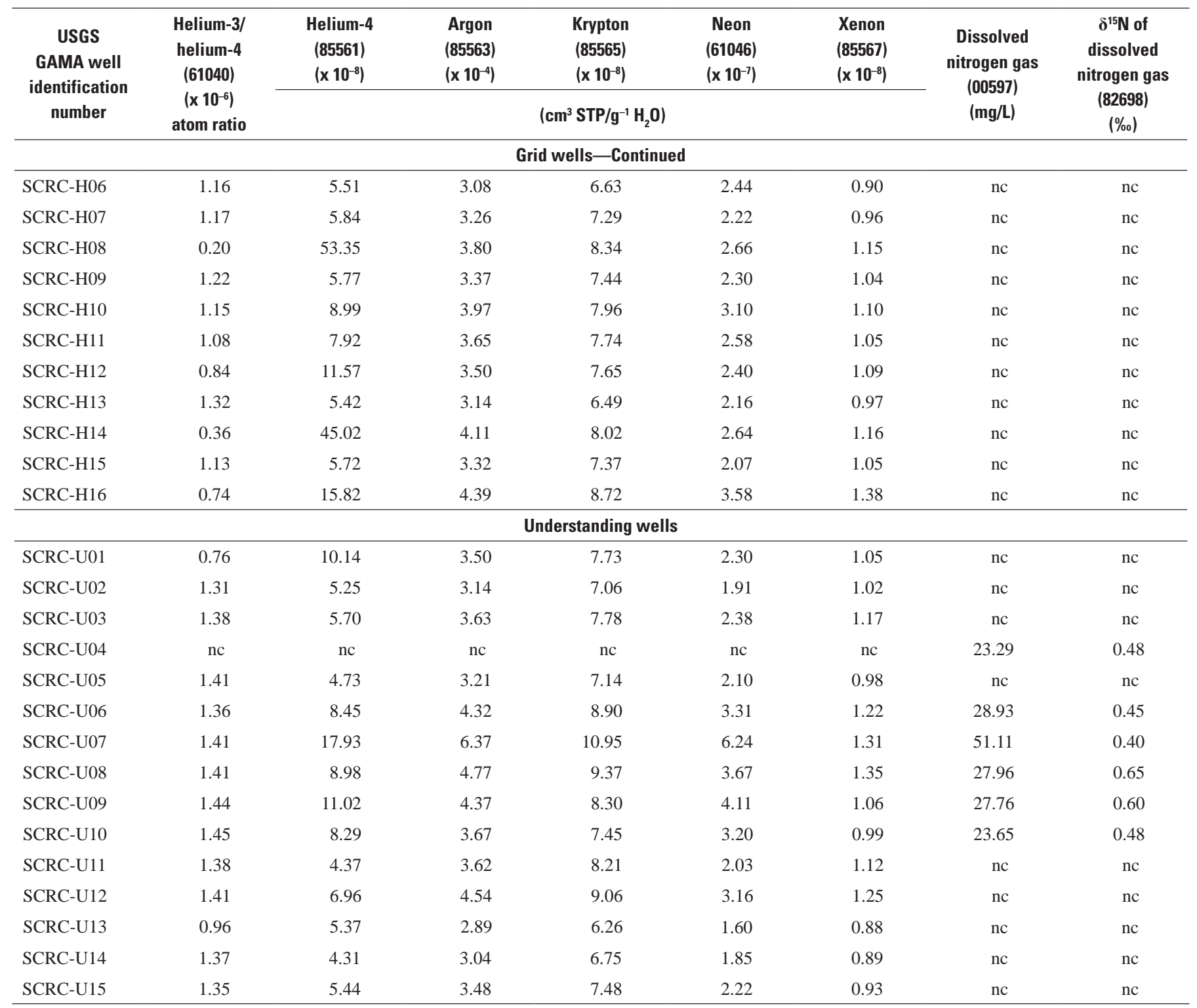


Publishing support provided by the U.S. Geological Survey Science

Publishing Network, Sacramento, Tacoma, and Raleigh Publishing Service Centers

For more information concerning the research in this report,

contact the

Director, California Water Science Center

U.S. Geological Survey

6000 J Street, Placer Hall

Sacramento, California 95819

http://ca.water.usgs.gov 



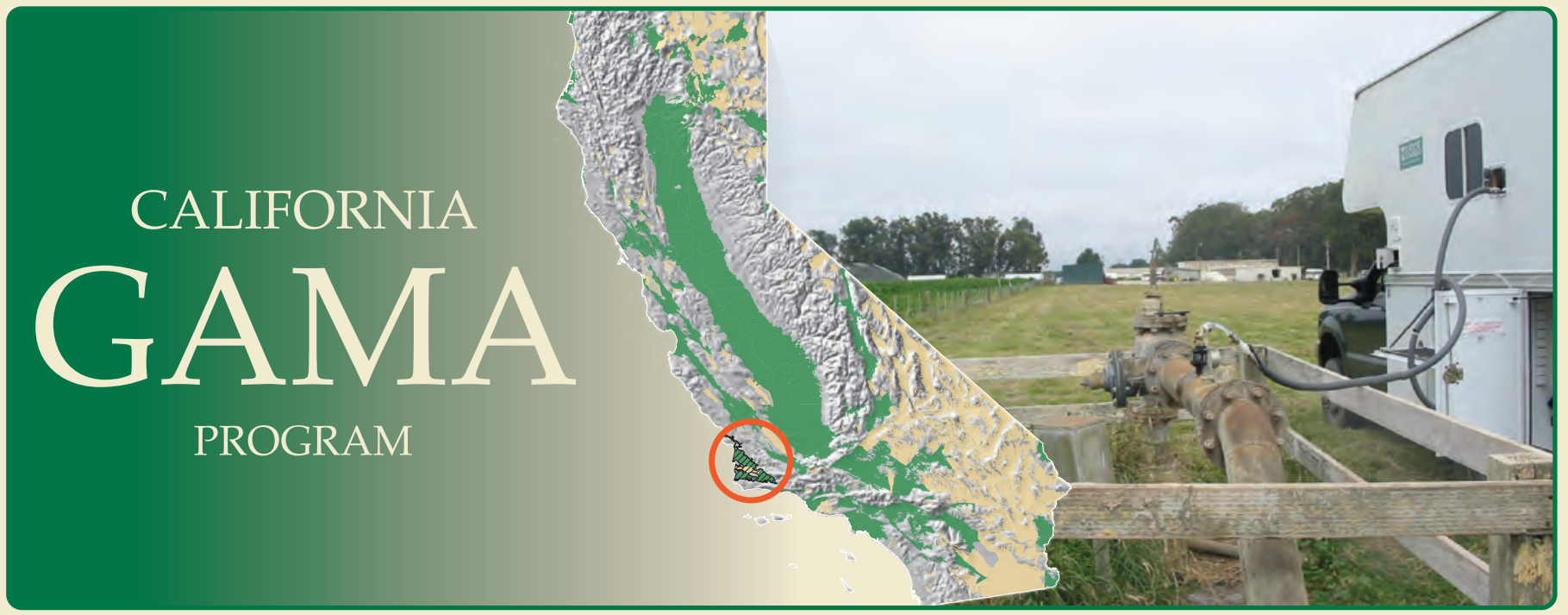

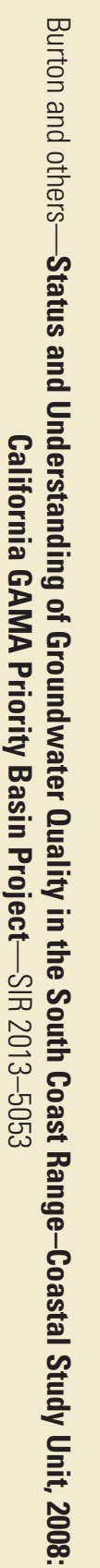

